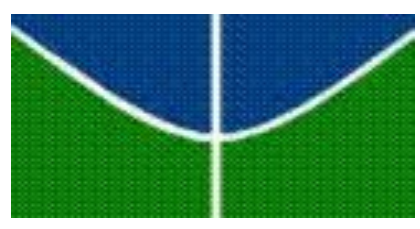

Universidade de Brasília

Faculdade de Educação - FE

Programa de Pós-Graduação em Educação

Educação Ambiental e Educação do Campo

WANESSA DE CASTRO

FORMAÇÃO DE EDUCADORES DO CAMPO E TECNOLOGIAS DIGITAIS: RELAÇÕES E DESAFIOS NA LICENCIATURA EM EDUCAÇÃO DO CAMPO DA UnB

Brasília, 16 de abril de 2015. 


\title{
FORMAÇÃO DE EDUCADORES DO CAMPO E TECNOLOGIAS DIGITAIS: RELAÇÕES E DESAFIOS NA LICENCIATURA EM EDUCAÇÃO DO CAMPO DA UnB
}

\begin{abstract}
Tese de Doutorado submetida ao Programa de PósGraduação em Educação da Faculdade de Educação da Universidade de Brasília como parte dos requisitos necessários para a obtenção do título de Doutora em Educação, linha de pesquisa Educação Ambiental e Educação do Campo.
\end{abstract}

Orientadora: Profa. Dra. Mônica Castagna Molina.

Brasília, 16 de abril de 2015. 
Ficha catalográfica elaborada automaticamente, com os dados fornecidos pelo(a) autor(a)

de Castro, Wanessa

Formação de Educadores do Campo e Tecnologias Digitais: Relaçoes e Desafios na Licenciatura em Educaçăo do Campo da UnB / Wanessa de Castro; orientador Mônica Castagna Molina. -- Brasilía, 2015. $241 \mathrm{p}$.

Tese (Doutorado - Doutorado em Educaça) -Universidade de Brasilia, 2015.

1. Educaçào do Campo. 2. Tecnologias Digitais. 3. Formaçăo docente. 4. Recursos Educacionais Abertos. 5. Letramento cientifico e digital. I. Castagna Molina, Mônica, orient. II. Título. 
UNIVERSIDADE DE BRASÍLIA

FACULDADE DE EDUCAÇÃO

PROGRAMA DE PÓS-GRADUAÇÃO EM EDUCAÇÃO

TESE DE DOUTORADO

FORMAÇÃO DE EDUCADORES DO CAMPO E TECNOLOGIAS DIGITAIS: RELAÇÕES E DESAFIOS NA LICENCIATURA EM EDUCAÇÃO DO CAMPO DA UnB

Wanessa de Castro

BANCA EXAMINADORA

Profa. Dra. Mônica Castagna Molina - Orientadora PPGE/FE/UnB

Profa. Dra. Eliete Ávila Wolff - Examinadora interna não vinculada ao PPGE/FE/UnB LedoC/FUP/UnB

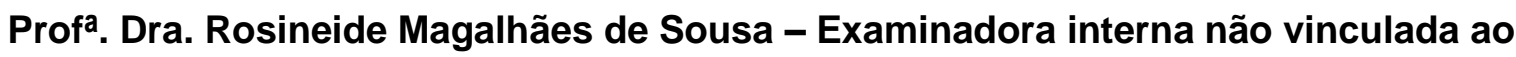
PPGE/FE/UnB

PPGL/UnB - LedoC/FUP/UnB

Profá. Dra. Vera Maria Catalão - Examinadora interna PPGE/FE/UnB

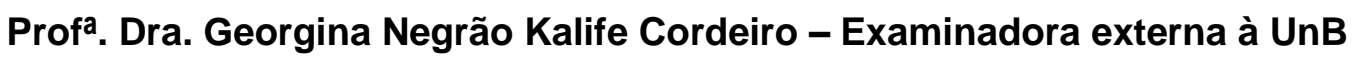
UFPA/PPLSA

Profa. Dra. Laís Maria Borges de Mourão Sá - Examinadora interna Suplente PPGE/FE/UnB 
Dedico este trabalho,

Ao meu pai, Edgar de Castro (In memoriam) e à minha mãe, Conceição Aparecida.

Aos meus irmãos Rosângela, Cássio, Edgar Júnior e Rachel Cristina.

Aos educadores do campo da Turma 2 da LEdoC-UnB, que vieram cortando o arame.

A tod@s aquelas e aqueles que acreditam na Educação como meio de transformação social. 


\section{Gratidão...}

Aos meus pais, pela vida dada e educação dispensada.

Aos meus irmãos e cunhad@s, pela confiança, apoio, carinho e paciência. Aos sobrinhos e sobrinhas que souberam entender minha ausência sem cobrança, mas com muito amor e carinho me apoiaram.

À amiga-irmã Mônica, pela orientação cuidadosa e pelo carinho incondicional.

À Irane, pela amizade, pelo cuidado, pela saúde.

Ao Dr. Marcelo Carvalho, por me içar do fundo do poço.

Ao meu compadre, cunhado, irmão Vicente, amigo para todas as horas e parceiro de ideologia.

À minha amiga-irmã Audrey, pela amizade incondicional, força, companheirismo, confiança, apesar de atravessar caminhos mais difíceis que os meus.

À sobrinha, amiga e confidente, Raiara, pela amizade, cumplicidade, paciência.

À minha prima-irmã Raquel, por acreditar em mim e me dar ânimo cotidiano para prosseguir.

Aos meus pais escolhidos, Anasor e Irene, pelo amor e amizade. Ao amigo Paulo César, pela paciência e pela confiança depositada. Ao amigo Valtinho, por não me abandonar na hora do apuro.

Às amigas Joesse e Elisângela, por acreditarem em mim e me encorajarem a continuar.

Às professoras Vera, Rosineide, Eliete e Izabel Antunes, da banca de qualificação e suas valiosas contribuições para esta investigação.

Aos membros da banca, Georgina, Vera, Rosineide, Eliete e Laís pelas contribuições e por aceitarem contribuir com este trabalho.

Aos colegas de doutorado, que em seu silêncio torciam pela minha recuperação e vitória.

Aos colegas da Comissão Discente, pela cumplicidade.

Aos professores do PPGE, tão parceiros e cúmplices em nossa jornada, em especial, Professora Laís, Professor Gilberto e Professor Célio.

À Coordenação do PPGE, principalmente à Professora Abádia, por acreditar em mim e me dar a oportunidade de concluir esta etapa. 
Aos colegas educadores da LEdoC, bravos companheiros na luta diuturna pela manutenção do curso e pela construção de um novo projeto societário.

Aos educandos de todas as turmas da LEdoC, que já estiveram conosco e nos ensinaram muito.

À Turma 2 da LEdoC, pela cumplicidade, pelo aprendizado e pela amizade. Às companheiras da LEdoC Anabela, Maria José, Erivan, Catarina, Ana Cristina, Elis e Mayara. Ao Márcio, pela parceria.

Ao Hildebrando e à Rita, pelo carinho de sempre nos receber e tratar com carinho, na busca de melhores fontes.

À Juliane, apoio certo na hora do desespero.

Aos colegas professores do CEP Saúde pela paciência, confiança e respeito ao meu trabalho.

Às colegas da CEDIV, pela parceria e confiança.

À amiga Sandra Zita, pelo apoio.

À SEEDF, pelo afastamento concedido nos dois primeiros anos de doutorado.

Aos amigos e às amigas, que me aturaram nos momentos de dor, de lamentações, de desesperança: Mateus, Jandina, Dagma, Sérgio, Ana Marques, Cinete, Fernanda, Janaína, Jaqueline, Erika, Adriana Marques, Adriana Fontenelle, Thaís, Fabíola, Dayana, Amanda, Rosi, Luis Carlos, Ana Lúcia, Cristiane, Rosane, Telma,

Neusimar, Sandro, Domingos, Rodrigo, Marcos MM, Gláucio, Diego, Bougleux,

Wilson, Eric, Kiko, Alisson, Leonardo, Manoel, Neuzinha, Josi, Newton, Elias, Pedro, Watson, Cláudio, Lúcia, Nivaldo, Ivana, Cris Camboim, Karina, Norma, Tigil, Olivan, Chris, Fernando e tod@s aqueles e aquelas que não cito o nome aqui, mas que estiveram ao meu lado durante essa jornada.

À Nelinda, pelo apoio em casa, me resgatando das minhas bagunças produtivas.

Aos meus filhotes de quatro patas Legs, Princesa, Pitty e Trenna (In memoriam), que não me abandonaram um só minuto e me deram seu amor incondicional, mesmo quando eu me sentia incapaz de amar e de cuidar. 
Al venir a la tierra, todo hombre tiene derecho a que se le eduque, y después, em pago, el deber de contribuir a la educación de los demás.

José Martí

É significativo que, ao lutarem pelo direito ao conhecimento, sempre colocam essas lutas na ocupação dos espaços, das estruturas, dos territórios do conhecimento e no criar espaços próprios, alternativos. Como lutam pela vida, ocupando a terra, espaço de produção da vida. Traduzem o direito à vida, identidade, cultura, tradição, aos saberes em ocupação dos territórios, de sua produção: a terra, o espaço, o trabalho, os territórios quilombolas, indígenas, de moradia. Ao lutarem pelo direito à educação, ao conhecimento, à herança cultural operam na mesma lógica: "ocupemos o latifúndio do saber" passou a ser o grito

político dos militantes/educadores que chegam aos cursos de Pedagogia da Terra, de Formação de Educadores indígenas, quilombolas, do campo.

Miguel Arroyo 
CASTRO, Wanessa de. Formação de educadores do campo e tecnologias digitais: relações e desafios na licenciatura em educação do campo da UnB. 2015. 238f. Tese (Doutorado em Educação - Educação Ambiental e Educação do Campo) - Faculdade de Educação, Universidade de Brasília, 2015.

\section{Resumo}

Este estudo teve como tema a formação de educadores do campo para o uso de Tecnologias Digitais na Licenciatura em Educação do Campo da Universidade de Brasília. Teve como sujeitos da pesquisa os educandos da Turma 2 da referida Licenciatura. O objetivo principal foi investigar e analisar em que medida 0 acesso e a apropriação das Tecnologias Digitais no processo de formação de educadores do campo ajudam a utilizar e produzir recursos educacionais contextualizados que possam provocar alterações, numa perspectiva transformadora/emancipadora, em suas práticas pedagógicas nas escolas do campo. Para isso, usou como fundamentação teórica: Educação do Campo; escolas do campo; formação de educadores do campo: a Licenciatura em Educação do Campo na UnB (LEdoC - UnB); tecnologias digitais, letramento digital e Recursos Educacionais Abertos; Comunicação e Tecnologias da Informação - a formação para uso das Tecnologias Digitais em processos educativos; história e conceito de Recursos Educacionais Abertos; criação, adaptação, uso e compartilhamento de REA; e tipos de licença Creative Commons. O percurso metodológico desenvolveu-se sob a perspectiva do Materialismo Histórico Dialético e foi realizada uma pesquisa-ação cuja abordagem foi qualitativa. Para a coleta de informações foram utilizados: questionário, entrevista estruturada online, observação participante e diálogos pedagógicos realizados em várias etapas do processo de pesquisa. A partir da pesquisa chegou-se à conclusão que, ao ingressar na LEdoC, os docentes em formação, em sua quase totalidade, não tinham conhecimentos informáticos básicos e puderam construí-los ao longo do curso tanto nas aulas de Comunicação e Tecnologias da Informação quanto nos demais componentes curriculares; também, concluiu-se que formar um educador do campo requer diferenciação no tratamento, no currículo, nas estratégias e nas práticas pedagógicas; ainda, que houve e continua a haver transformação social tanto na vida desses docentes, agora formados como nas comunidades campesinas das quais eles fazem parte; que a utilização de Recursos Educacionais Abertos amplia muito as possibilidades de formação desses sujeitos; também que o uso de Tecnologias Digitais e REA, por si só, não promove transformação nas práticas pedagógicas, essa transformação somente acontecerá a partir de um conjunto de situações que tenham essa mudança como um de seus objetivos. Assim, o objetivo inicial dessa pesquisa, além de ser alcançado, ainda permitiu ampliar o escopo da pesquisa para utilização e produção de Recursos 
Educacionais Abertos, complementando a ideia de prática emancipatória por não utilizar programas e aplicativos pagos e compartilhar materiais que podem auxiliar outros educadores do campo. Por fim, a título de recomendação, foi feita a sugestão da criação do componente curricular Letramento Científico e Digital como disciplina e não mais oficina, com carga horária ampliada em relação à Oficina de Informática e com a criação de vaga para professor efetivo para este novo componente.

Palavras-chave: Educação do Campo; Tecnologias Digitais; Recursos Educacionais Abertos; Formação docente. 


\begin{abstract}
This study had as its theme the formation of field educators for the use of Digital Technologies in Education Degree in the Field of the University of Brasilia. We had as research subjects the students of Class 2 of the Bachelor. The main objective was to investigate and analyze to what extent access to and ownership of Digital Technologies in the formation of the field educators help you use and produce contextualized educational resources that can cause changes in a transforming / emancipatory perspective in their teaching practices in schools in the field. For this, it was used as theoretical foundation: Rural Education; schools in the field; training of field educators: a BA in Education Field at UNB (LEdoC UNB); digital technologies, digital literacy and Open Educational Resources; Communication and Information Technology - training for use of Digital Technologies in educational processes; history and concept of Open Educational Resources; creation, adaptation, use and sharing of OER; and types of Creative Commons license. The methodological approach was developed from the perspective of Dialectical Materialism Historical and an action research was carried out whose approach was qualitative. For the collection of information were used: questionnaire, online structured interview, participant observation and teaching dialogues conducted at various stages of the research process. From the research was reached the conclusion that by joining LEdoC, teachers in training, almost entirely, had no basic computer skills and were able to build them throughout the course both in communication classes and Information Technology as in other curriculum components; Also, it was concluded that to form a field educator requires differentiation in the treatment, the curriculum, the strategies and teaching practices; still, there was and continues to have social transformation both in the lives of teachers, now formed as the field communities of which they are part; that the use of Open Educational Resources enlarge training opportunities these subjects; also that the use of Digital Technologies and SSA alone, does not promote change in teaching practices, this transformation will only happen from a set of situations that have this change as one of its objectives. Thus, the initial objective of this research, in addition to being achieved, still allowed to broaden the scope of research for use and production of Open Educational Resources, complementing the idea of emancipatory practice not to use paid programs and applications and materials that can assist other educators field. Finally, by way of recommendation, the suggestion of the curricular component of the creation Scientific and Digital Literacy as a discipline and not more workshop was made with expanded hours relative to Informatic Workshop and the creation of a vacancy for effective teacher for this new component.
\end{abstract}

Keywords: Rural Education; Digital Technologies; Open Educational Resources; Teacher training. 


\section{Resumen}

Este estudio tuvo como tema la formación de educadores de campo para el uso de las Tecnologías Digitales en Licenciatura en Educación Rural de la Universidad de Brasilia. Teníamos como sujetos de investigación los estudiantes de la Clase 2 de la Licenciatura. El objetivo principal fue investigar y analizar en qué medida el acceso y apropiación de las tecnologías digitales en el proceso de la formación del profesorado rural ayuda que utiliza y producir recursos educativos contextualizados que pueden causar cambios en la perspectiva emancipadora en sus prácticas de enseñanza en las escuelas en el campo. Para ello, se utiliza como base teórica: Educación Rural; las escuelas en el campo; formación de educadores campesinos: una Licenciatura en Educación Rural de la UnB (LEdoC - UNB); tecnologías digitales, la alfabetización digital y los recursos educativos abiertos; Comunicación y Tecnología de la Información - formación para el uso de las tecnologías digitales en los procesos educativos; la historia y el concepto de los recursos educativos abiertos; creación, adaptación, uso e intercambio de REA; y los tipos de licencia Creative Commons. El enfoque metodológico desarrollado desde la perspectiva del materialismo dialéctico histórico y una investigación-acción se llevó a cabo cuyo enfoque fue cualitativo. Para la recolección de información se utilizaron: cuestionario, entrevista en línea estructurada, la observación participante y diálogos didácticos realizados en las distintas etapas del proceso de investigación. De la investigación llegó a la conclusión de que, al entrar en el LEdoC, maestros en formación, casi en su totalidad, no tenían conocimientos básicos de informática y fueron capaces de construir a lo largo del curso, tanto las clases de Comunicación y Tecnología de la Información como en otros componentes del plan de estudios; Además, se concluyó que forman un educador de campo requiere la diferenciación en el tratamiento, el plan de estudios, las estrategias y las prácticas de enseñanza; aún así, no era y sigue siendo la transformación social, tanto en la vida de los maestros, ahora formadas como las comunidades campesinas de los que forman parte; que el uso de los recursos educativos abiertos se extiende mucho las oportunidades de formación de estos temas; también que el uso de las tecnologías digitales y los recursos educativos abiertos en sí misma no promueve cambios en las prácticas de enseñanza, esta transformación sólo será posible a partir de un conjunto de situaciones que tienen este cambio como uno de sus objetivos. Por lo tanto, el objetivo inicial de esta investigación, además de ser alcanzado, todavía se permite ampliar el alcance de la investigación para el uso y producción de recursos educativos abiertos, como complemento de la idea de la práctica emancipadora no utilizar los programas y aplicaciones de pago y compartir materiales que pueden ayudar a otros educadores campo. Por último, a modo de recomendación, la sugerencia del componente curricular de la creación de alfabetización científica y digital como una disciplina y no más taller se realizó con horas ampliadas relativas a la Información Tecnología de Taller y la creación de un puesto vacante de maestro eficaz de este nuevo componente.

Palabras clave: Educación Rural; Las tecnologías digitales; Recursos Educativos Abiertos; La formación del profesorado. 


\section{Lista de ilustrações}

Figura 1: Matriz Curricular da Licenciatura em Educação do Campo - UnB...................... 85

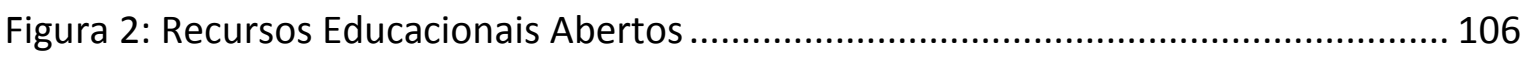




\section{Lista de gráficos}

Gráfico 1: Atuação na docência antes da LEdoC ......................................................... 138

Gráfico 2: Atuação na docência depois da LEdoC ...................................................... 140

Gráfico 3: Uso do computador para planejamento das aulas....................................... 144

Gráfico 4: Uso do computador e Internet para preparação de materiais ....................... 145

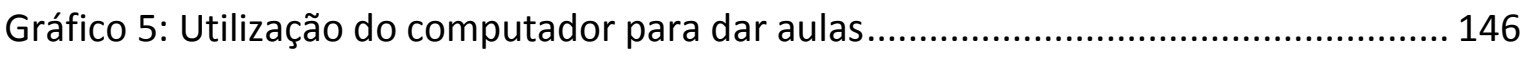

Gráfico 6: Local de utilização de computador e Internet para aulas .............................. 147

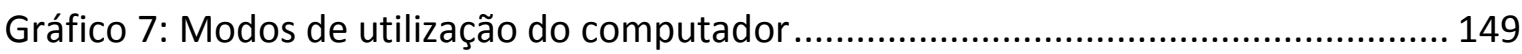

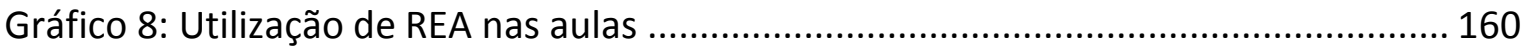

Gráfico 9: Produção e/ou adaptação de REA para uso em aulas..................................... 161

Gráfico 10: Produção de REA específico para escolas do campo...................................... 162 


\section{Lista de tabelas}

Tabela 1: Tipos de licenças Creative Commons 115

Tabela 2: Mudanças na prática pedagógica após o uso de computador e Internet........ 151

Tabela 3: Relação educando-educador após as Tecnologias Digitais ............................. 153

Tabela 4: Relação educando-conhecimento após as Tecnologias Digitais ...................... 155

Tabela 5: Facilidades e dificuldades no trabalho pedagógico com apoio das Tecnologias Digitais 156

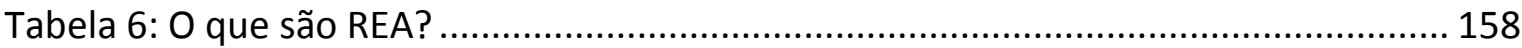

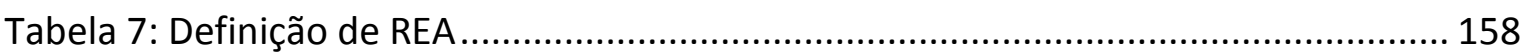

Tabela 8: REA nas práticas pedagógicas de educadores do campo ................................ 164 


\section{Lista de abreviaturas e siglas}

\begin{tabular}{|c|c|}
\hline AVA & Ambiente Virtual de Aprendizagem \\
\hline CAPES & Coordenação de Aperfeiçoamento de Pessoal de Nível Superior \\
\hline CC & Creative Commons \\
\hline CEBEP & Conflitos Estruturais Brasileiros e Educação Popular \\
\hline CEFFAs & Centros Familiares de Formação em Alternância \\
\hline CERI & Centre for Educational Research and Innovation \\
\hline CESPE & Centro de Seleção e Promoção de Eventos \\
\hline CETEC & $\begin{array}{l}\text { Centro Transdisciplinar de Educação do Campo e Desenvolvimento } \\
\text { Rural }\end{array}$ \\
\hline CF & Constituição Federal \\
\hline CNBB & Conferência Nacional dos Bispos no Brasil \\
\hline CNE & Conselho Nacional de Educação \\
\hline CNEBC & Conferência Nacional Educação Básica do Campo \\
\hline CNEC & Conferência Nacional de Educação do Campo \\
\hline CNTE & Confederação Nacional dos Trabalhadores em Educação \\
\hline CONAE & Conferência Nacional de Educação \\
\hline CONEB & Conferência Nacional de Educação Básica \\
\hline CONEC & Comissão Nacional de Educação do Campo \\
\hline CONSED & Conselho Nacional de Secretários de Educação \\
\hline CONTAG & Confederação Nacional dos Trabalhadores na Agricultura \\
\hline CPT & Comissão Pastoral da Terra \\
\hline CTI & Comunicação e Tecnologias da Informação \\
\hline CUT & Central Única de Trabalhadores \\
\hline EFAS & Escolas Famílias Agrícolas \\
\hline
\end{tabular}


EJA Educação de Jovens e Adultos

EMBRAPA Empresa Brasileira de Pesquisa Agropecuária

ENERA Encontro Nacional dos Educadores da Reforma Agrária

FEDF Fundação Educacional do Distrito Federal

FETAGs Federações Estaduais de Trabalhadores Rurais

FETRAF Federação dos Trabalhadores na Agricultura Familiar

FNDE Fundo Nacional de Desenvolvimento da Educação

FONEC Fórum Nacional de Educação no Campo

FSF

Free Software Foundation

FUNDEB

FUNDEF

Fundo de Desenvolvimento do Ensino Fundamental e Valorização do Magistério

FUP Faculdade UnB Planaltina

GNU GNU's not Unix

GNU GPL GNU General Public License

GPT

Grupo Permanente de Trabalho

GT

Grupo de Trabalho

IBGE

Instituto Brasileiro de Geografia e Estatística

IES

Instituições de Ensino Superior

INCRA Instituto Nacional de Colonização e Reforma Agrária

INEP Instituto Nacional de Estudos e Pesquisas Educacionais Anísio Teixeira

IOC Inserção Orientada na Comunidade

IOE Inserção Orientada na Escola

IPEA Instituto de Pesquisa Econômica Aplicada 
ITERRA Instituto Técnico de Capacitação e Pesquisa da Reforma Agrária

LDB Lei de Diretrizes e Bases

LEdoC Licenciatura em Educação do Campo

MAB Movimento dos Atingidos por Barragens

MAMA Movimento das Mulheres da Amazônia

MASTER Movimento dos Agricultores sem Terra

MDA Ministério do Desenvolvimento Agrário

MEB Movimentos Eclesiais de Base

MEC Ministério da Educação

MHD Materialismo Histórico Dialético

Minc Ministério da Cultura

MLT Movimento de Luta pela Terra

MMC Movimento de Mulheres Camponesas

MMTR Movimento das Mulheres Trabalhadoras Rurais

MONAPE Movimento Nacional dos Pescadores

MOODLE Modular Object-Oriented Dynamic Learning Environment

MPA Movimento dos Pequenos Agricultores

MST Movimento dos Trabalhadores Rurais Sem Terra

MSTTR Movimento Sindical de Trabalhadores e Trabalhadoras Rurais

MTD Movimento dos Trabalhadores Desempregados

NAl Núcleo de Atividades Integradoras

NEB Núcleo de Estudos Básicos

NEE Núcleo de Estudos Específicos

NR Nota do Redator 
Nota do Tradutor

OCDE Organização para a Cooperação e Desenvolvimento Econômico

OCW OpenCourseWare

OER Open Educational Resources

ONGs Organizações não Governamentais

ONU Organização das Nações Unidas

PADRS Projeto Alternativo de Desenvolvimento Rural Sustentável

PASEP Programa de Formação do Patrimônio do Servidor Público

PER Proposta de Educação Rural

PIB Produto Interno Bruto

PIS Programa de Integração Social

PNAD Pesquisa Nacional por Amostra de Domicílios

PNATE Programa Nacional de Apoio ao Transporte Escolar

PNE Plano Nacional de Educação

PNLD Programa Nacional do Livro Didático

PNLD-Campo Programa Nacional do Livro Didático - Campo

PNRA Plano Nacional de Reforma Agrária

PPP Projeto Político Pedagógico

Procampo Programa de Apoio à Formação Superior em Licenciatura em Educação para o Campo

ProJovem Programa Nacional de Inclusão de Jovens

Pronacampo Programa Nacional de Educação do Campo

PRONERA Programa Nacional de Educação na Reforma Agrária

REA Recursos Educacionais Abertos

RO Reflexões do Observador 
SEB

SECADI

SEED

SEESP

SESu

SETEC

SNCR

TC

TD

TE

TER

TIC

UBM

UFMG

UGT

ULTAB

UnB

UNDIME

UNEFAB

UNESCO
Secretaria de Educação Básica

Secretaria de Educação Continuada, Alfabetização, Diversidade e Inclusão

Secretaria de Educação a Distância

Secretaria de Educação Especial

Secretaria de Educação Superior

Secretaria de Educação Profissional e Tecnologia

Sistema Nacional de Cadastro Rural

Tempo Comunidade

Tecnologias Digitais

Tempo Escola

Transporte Escolar Rural

Tecnologias de Informação e Comunicação

União Brasileira de Mulheres

Universidade Federal de Minas Gerais

União Geral dos Trabalhadores

União dos Lavradores e Trabalhadores Agrícolas do Brasil

Universidade de Brasília

União Nacional dos Dirigentes Municipais de Educação

União Nacional das Escolas Famílias Agrícolas do Brasil

Organização das Nações Unidas para Educação a Ciência e a Cultura 
Formação de Educadores do Campo e Tecnologias Digitais: Relações e Desafios na Licenciatura em Educação do Campo da UnB

\section{SUMÁRIO}

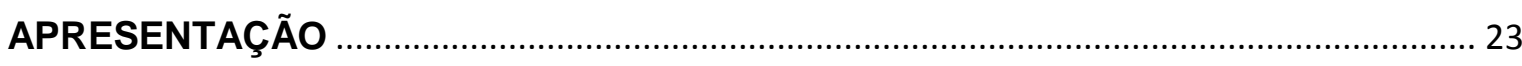

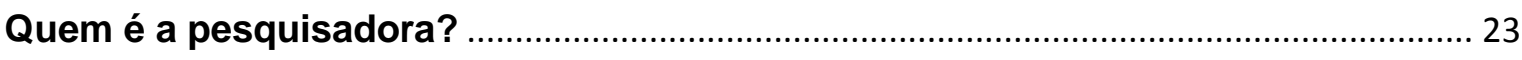

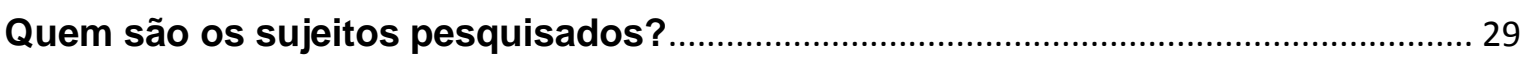

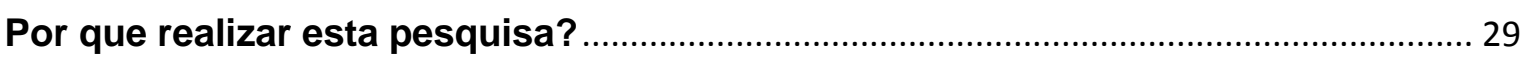

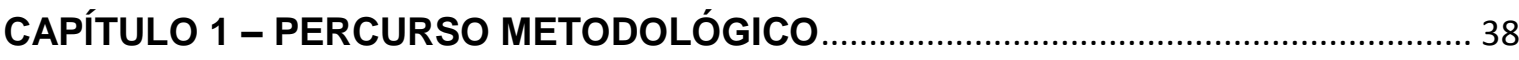

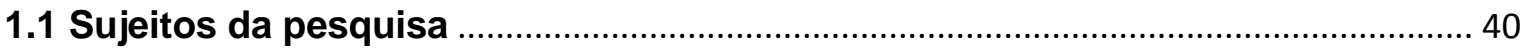

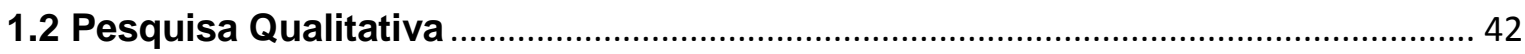

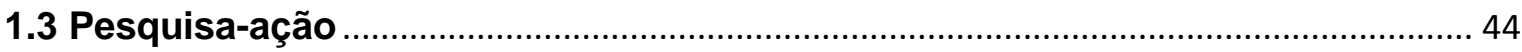

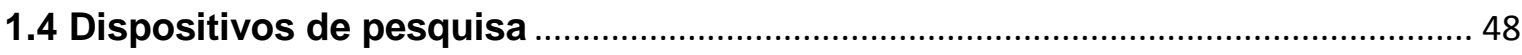

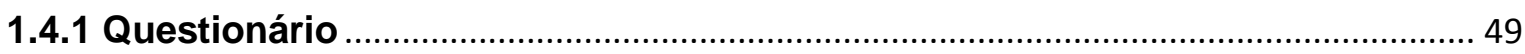

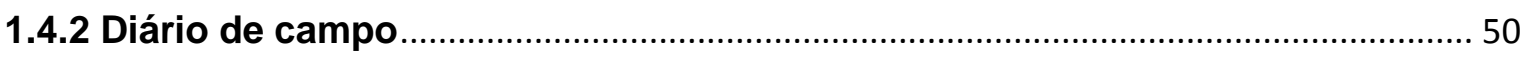

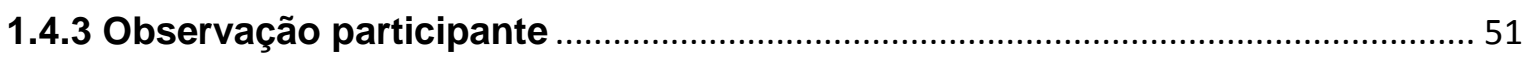

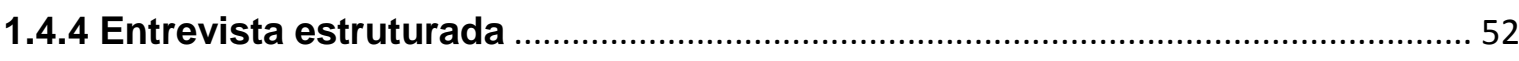

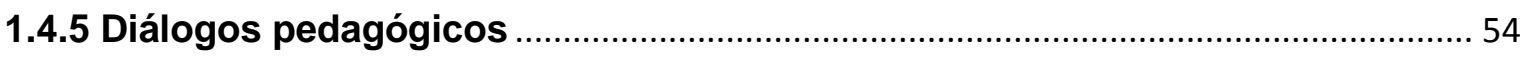

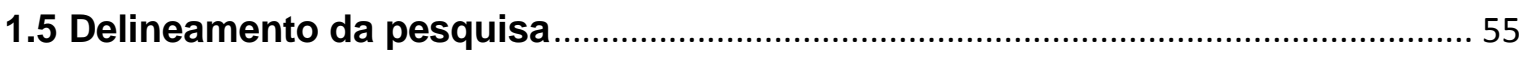

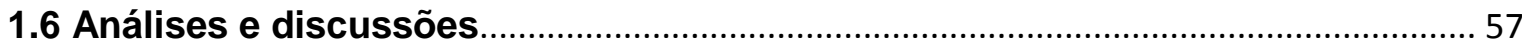

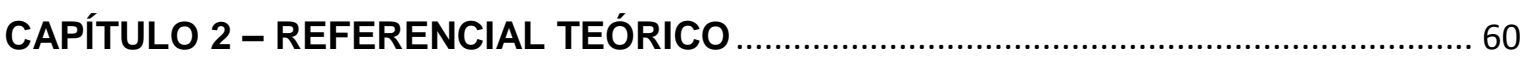

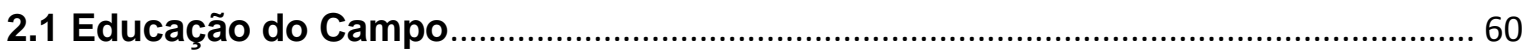

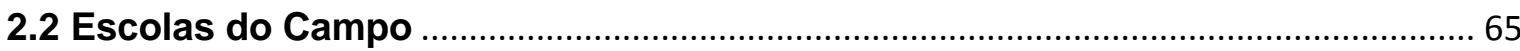

2.3 Formação de Educadores do Campo: a Licenciatura em Educação do Campo

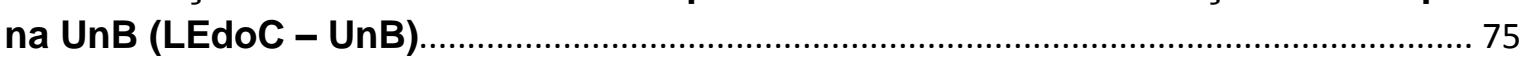

2.4 Tecnologias Digitais, Letramento Digital e Recursos Educacionais Abertos.... 92

2.4.1 Letramento digital e educadores do campo ........................................................ 94

2.4.2 Comunicação e Tecnologias da Informação - a formação para uso das Tecnologias Digitais em processos educativos .............................................................. 97

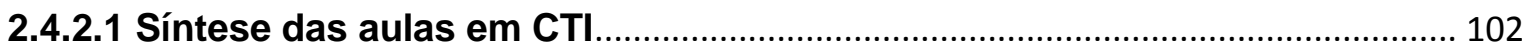

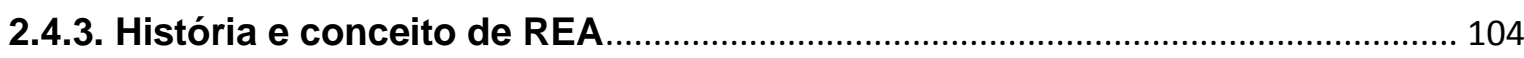

2.4.4 Recursos Educacionais Abertos e Educação do Campo.................................... 109 
2.4.5 Criação, adaptação, uso e compartilhamento de REA ...................................... 112

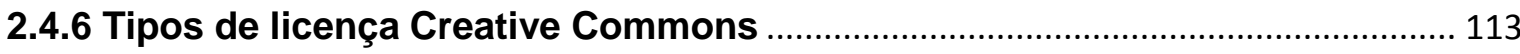

CAPÍTULO 3 - TRILHAR CAMINHOS, TECER COMPREENSÕES .............................. 117

3.1 Um sucinto diagnóstico sobre a Turma 2 e as Tecnologias Digitais .................. 121

3.2 Compreensões de todo um percurso, desafios às transformações na Escola do

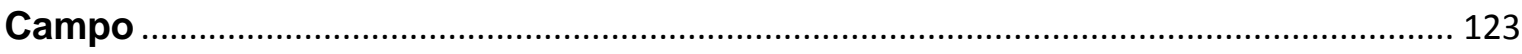

3.2.1 Políticas públicas e exclusão digital no campo................................................. 123

3.2.2 Instrumentalização, formação e interdisciplinaridade ...................................... 128

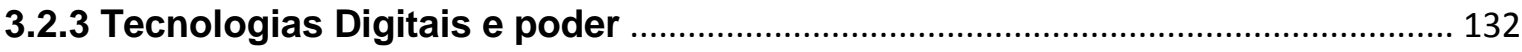

3.2.4 Desvantagens do uso do computador e da Internet......................................... 135

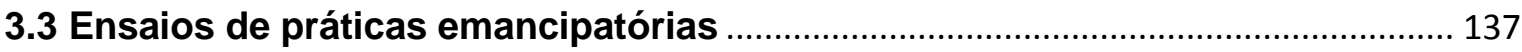

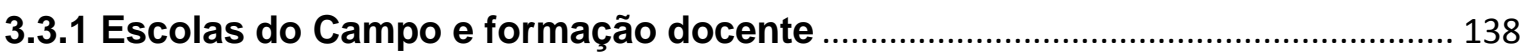

3.3.2 Tecnologias Digitais e coordenação pedagógica.............................................. 141

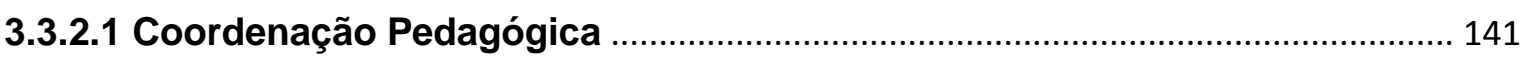

3.3.3 Tecnologias Digitais e Educação do Campo: um desafio.................................. 146

3.3.4 Sujeitos do campo, relações educativas e Tecnologias Digitais ...................... 150

3.3.5 Maior horizontalidade na relação educando-educador....................................... 152

3.3.6 Maior horizontalidade na relação educando-conhecimento ……...................... 154

3.3.7 Facilidades e dificuldades no uso de Tecnologias Digitais............................. 155

3.3.8 Recursos Educacionais Abertos e Educação do Campo: potencialidades à

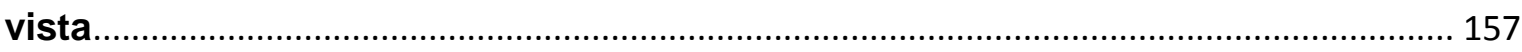

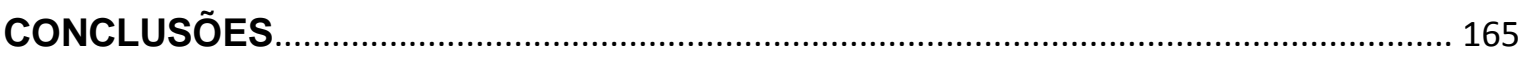

CONSIDERAÇÕES FINAIS E RECOMENDAÇÕES ..................................................... 170

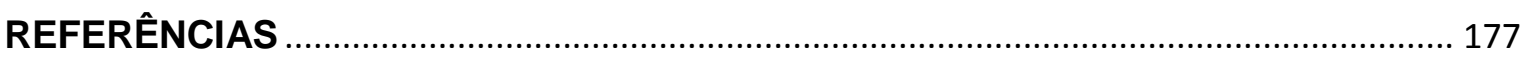

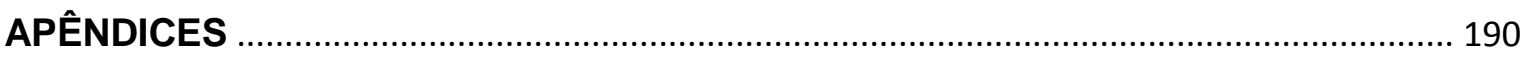

APÊNDICE A - Questionário sobre Recursos de Tecnologia da Informação........... 191

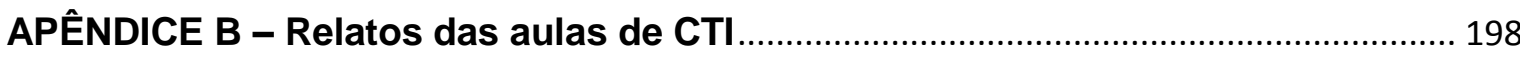

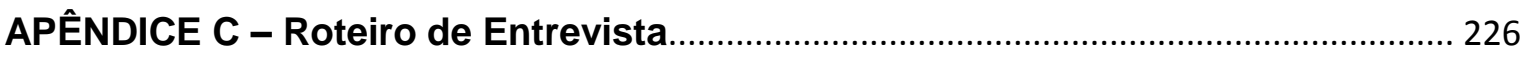

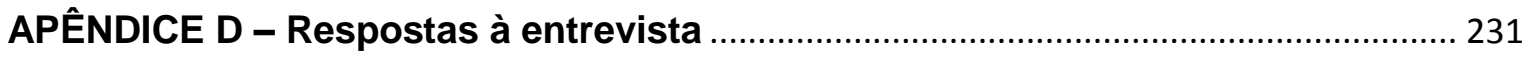

APÊNDICE E - Termo de Consentimento Livre e Esclarecido .................................... 241 


\section{Formação de Educadores do Campo e Tecnologias Digitais: Relações e Desafios na Licenciatura em Educação do Campo da UnB}

\section{APRESENTAÇÃO}

Discutir o uso de Tecnologias Digitais por sujeitos do campo em nosso país é sempre desafiador, principalmente quando essa discussão é feita por meio de um viés emancipador. E é esse o desafio por nós proposto neste trabalho, analisar se e como a produção e uso de materiais digitais elaborados a partir do contexto em que a escola do campo está inserida contribui para a construção de práticas pedagógicas transformadoras de educadores formados pela Licenciatura em Educação do Campo da Universidade de Brasília.

Para enfrentar tal desafio, seria necessário o envolvimento direto da pesquisadora com o grupo pesquisado, seu engajamento às causas defendidas pelo grupo e possuir objetivos comuns, dada a necessidade de realizar uma pesquisa tendo a prática social como critério da verdade (TRIVIÑOS ${ }^{1}, 2008$, p.64). Envolvimento e engajamento existem e para que o leitor deste trabalho tenha clareza disso, cabe-nos mostrar como essa investigação foi se construindo ao longo da trajetória pessoal, profissional e acadêmica da pesquisadora.

\section{Quem é a pesquisadora?}

Nasci e cresci em Planaltina - DF, onde durante toda minha infância e adolescência estudei em escola pública, aliás, sempre a mesma escola na Educação Infantil, Ensino Fundamental e Médio, o Centro Educacional 01 de Planaltina, também conhecido na cidade como Centrão.

Meu contato com o meio rural e a vida no campo iniciou mesmo antes de eu ter consciência de qualquer diferenciação entre campo e cidade. Meu pai foi servidor do Ministério da Agricultura e morou na Antiga Fazenda Modelo,

\footnotetext{
${ }^{1}$ Marx afirmava que a solução "de contradições teóricas é possível unicamente pela vida da prática". A prática individual e a prática social estão intimamente relacionadas. "A prática individual pode realizar-se e desenvolver-se com êxito unicamente sobre a base da prática histórico-social, acumulada pela humanidade ao longo dos séculos; por outro, a prática social se desenvolve e enriquece através da atividade prática e teórica dos diferentes indivíduos (científicos, dirigentes sociais e políticos, operários das empresas etc.) e coletividades." (TRIVIÑOS, 2008, p.64).
} 
hoje uma das sedes rurais da EMBRAPA, onde também residiu, por bastante tempo, minha avó paterna e meus tios. Desde muito pequena frequentava a casa desses e outros familiares que moravam em sítios e participava dos processos de plantio e colheita de alimentos diversos, lidava com animais como galinhas, cavalos, vacas, ovelhas, com naturalidade. Isso sempre fez parte de meu universo.

Minha tia e minha irmã, quando começaram a atuar como professoras, trabalharam em escolas rurais e eu as acompanhava sempre que possível. Achava mágico estar naqueles lugares, parecia ser outro mundo e eu podia tocar todo ele, ali me sentia completa.

Talvez, por uma relação harmoniosa com esse ambiente, sempre me interessei pelas situações relacionadas à natureza e à vida no campo e acabei indo trabalhar em uma escola rural quando passei no primeiro concurso que fiz (na antiga FEDF - Fundação Educacional do Distrito Federal), logo ao sair do curso Normal, (como chamávamos o Ensino Médio) com profissionalização na área do Magistério, para atuação nos anos iniciais do Ensino Fundamental.

Nessa pequena escola em que trabalhei durante um ano pude experimentar o que muitos professores do nosso país experimentam: morei em um quartinho da escola por alguns meses devido à falta de transporte entre a cidade e a escola, voltando para casa apenas nos fins de semana. Era um período de privações em relação à vida urbana, mas de muita riqueza em termos de relações pessoais. Aprendi muito com as pessoas daquele lugar, principalmente, aprendi sobre a solidariedade e sobre a humildade, os maiores aprendizados que uma jovem em início de vida profissional pode receber.

Ali tive minha primeira experiência com uma situação que muitos se deparam ao chegar a uma escola rural: turmas multisseriadas. No período matutino eu trabalhava com uma turma multisseriada com as quatro séries iniciais em uma única turma e no vespertino era do mesmo jeito. Então, discutindo com a professora responsável ${ }^{2}$ pela escola, questionei o fato das duas turmas funcionarem dessa forma, se não seria melhor colocar em um

\footnotetext{
${ }^{2}$ Naquela época as escolas rurais pequenas não tinham direção instituída no DF, apenas um professor que fazia o papel de diretor, secretário, coordenador e o que mais fosse necessário como merendeira, servidora da limpeza etc.
} 
turno todos os estudantes de primeira e segunda série e no outro os estudantes de terceira e quarta, caso a comunidade não se opusesse. Assim, facilitaria o trabalho da professora e melhoraria a relação entre estudantes de uma mesma faixa etária, pois tínhamos crianças de 6 a 17 anos em uma mesma classe em cada turno.

Conseguimos colocar em prática minha ideia, o que melhorou muito a qualidade do trabalho e o aprendizado das crianças. Mesmo assim, com turmas multisseriadas nos dois períodos e sem experiência nenhuma, eu ia tentando fazer o que podia e pesquisando formas de melhorar minha relação com a comunidade para trabalhar a partir de suas especificidades. Foi um sofrimento, mas também um grande aprendizado.

Ainda trabalhei mais 2 anos em outra escola rural com características diferenciadas por estar localizada em uma região periurbana e não totalmente rural como a primeira, antes de ir trabalhar na área urbana e me deparar com uma realidade completamente diferente das escolas em que havia trabalhado anteriormente. Foi nesta época que descobri a riqueza de cultura, diversidade, solidariedade, religiosidade, amorosidade e tantos outros atributos existentes nas comunidades do campo.

O que posso dizer com isto é que eu já passei pela experiência de trabalhar em escolas rurais e vivenciei muitas das situações a que nossos colegas são submetidos: ausência de transporte, longas distâncias, falta de material, livros descontextualizados, turmas multisseriadas, ausência de apoio pedagógico, administrativo e logístico para trabalhar, comunidades extremamente carentes, mas com enorme potencial humano.

Já em 1995, fui convidada a fazer parte de uma instância da antiga FEDF que era responsável por dar assistência (mais administrativa que pedagógica) às escolas rurais do Distrito Federal e aceitei. Foi um período muito intenso em que visitávamos, diariamente, de 3 a 4 escolas por dia, fazendo levantamento das necessidades das escolas, necessidades essas que não eram poucas, e também fazíamos orientação e acompanhamento pedagógico aos professores e gestores das escolas. Conheci as 101 escolas rurais do DF existentes na época. Muita diversidade. Problemas de toda ordem. Riqueza enorme em termos de relações. De lá para cá, das 101 escolas 
restaram 75 que continuam em localização rural, as demais, ou foram fechadas, ou foram engolidas pelas cidades no crescimento desordenado pelo qual tem passado o Distrito Federal nesses vinte anos.

Também, neste mesmo período, iniciamos diálogos com diversos órgãos do Governo do DF e também da Universidade de Brasília no sentido de realizarmos trabalhos conjuntos em benefício das comunidades do campo e em prol da melhoria das escolas ali situadas. Desses diálogos surgiu um Grupo de Trabalho Interinstitucional que discutia a educação dos povos do campo ligados aos movimentos de Reforma Agrária. Este grupo ficou encarregado de organizar o evento nacional que traria de todo o país educadores populares ligados aos acampamentos e assentamentos de Reforma Agrária, bem como educadores de escolas rurais de todo o país. Este evento era a culminância que ocorreria em Luziânia-GO após os eventos regionais que tirariam delegados para o evento nacional denominado Conferência Nacional por uma Educação Básica do Campo. Também neste Grupo de Trabalho tiramos os responsáveis pela organização do Encontro Regional por uma Educação Básica do Campo que aconteceria em Sobradinho-DF, da qual participariam educadores das escolas rurais do DF, bem como educadores populares ligados às questões da Reforma Agrária e acampamentos Sem Terra locais.

Foram dois eventos riquíssimos de onde emergiram as questões que são basilares da Educação do Campo atualmente. Da Conferência Nacional saíram desafios e propostas de ação em um documento que, ainda hoje, norteia as ações ligadas à Educação do Campo.

Fazer parte desse Grupo de Trabalho e da Coordenação de Organização dos eventos me proporcionou aprendizados diversos, estabelecimento de relações importantes até hoje e, principalmente, me despertou para a necessidade de participar de ações voltadas para a transformação da realidade de nosso país. Foi ali que despertei para a necessidade de pensarmos um novo projeto de Nação que fosse pensado com a maioria dos brasileiros, para a camada excluída, para aquelas pessoas que nem ao menos tinham ideia que eram detentoras de direitos.

Nesse mesmo período pude participar de diversos eventos relacionados às questões do campo e da educação do campo, como: 
$\checkmark$ O Grito da Terra - evento anual em que os movimentos sociais do campo deslocam-se para Brasília com a finalidade trazer as discussões e reivindicações de suas comunidades relacionadas às questões agrárias, sociais, educacionais, culturais, sanitárias, ambientais, dentre outras, em forma de um documento a ser entregue à/ao Presidente da República. Esse evento tem também o intuito de mostrar/lembrar a toda sociedade brasileira a importância do campo brasileiro e a necessidade que toda população olhe para essa população e para suas demandas com um olhar menos excludente e marginalizado, colocando em evidência sua importância em relação às questões atinentes à soberania alimentar do país.

$\checkmark$ Encontro Nacional de Meninos e Meninas Trabalhadores Rurais - evento que também acontecia anualmente e que era de fundamental importância para as discussões relacionadas à educação e aos direitos dessa parcela da comunidade campesina. Nesse evento eram discutidas, por exemplo, a necessidade de erradicação do trabalho infantil no campo, as reivindicações das crianças e adolescentes em relação à escola do campo e a necessidade de discutir as especificidades e diferenças existentes entre a escola do campo e a escola da cidade.

$\checkmark$ Marcha das Margaridas - evento anual do movimento das mulheres do campo em busca da elaboração e sanção de leis e políticas públicas de garantia de direitos para esse segmento tão excluído socialmente.

Esses são apenas alguns dos eventos dos quais participei, seja no apoio à organização, seja nas discussões relacionadas ao campo da educação.

A partir desse despertar, minha vida profissional não foi mais a mesma, pois não bastava mais apenas ir para a sala de aula e fazer a minha parte como educadora, a partir dali, eu também tinha a obrigação de fazer mais por mim e pelos meus iguais. Apesar disso, após voltar à sala de aula, em 1999, fiquei um tempo afastada das discussões relacionadas à Educação do Campo, 
apenas observando os movimentos a distância dada a falta de tempo para dedicar-me à causa.

De 2001 a 2004 cursei Pedagogia na Universidade de Brasília, mas não houve aproximação com o tema nesse período. Apenas discussões superficiais que tocavam as questões relacionadas às escolas rurais e à educação do campo.

Ao cursar disciplinas do Programa de Pós-graduação em Educação na Faculdade de Educação da Universidade de Brasília, em 2006, qual não foi minha surpresa ao me deparar com um projeto de Licenciatura em Educação do Campo - LEdoC apresentado por um coletivo de professores em uma disciplina que eu cursava denominada Fundamentos da Transdisciplinaridade. Meus olhos brilharam! Meu coração se encheu de alegria! O projeto de Educação do Campo estava mais vivo que nunca e havia planos em fase de concretização para que as educadoras e os educadores do campo pudessem cursar uma graduação em regime de alternância, dentro das especificidades das quais faziam parte e partindo de um projeto que continuaria a ser construído com suas próprias contribuições.

Ao mesmo tempo em que cursava um mestrado em Educação e Comunicação, ficava a me perguntar de que modo essa formação me serviria para voltar a me envolver nas discussões sobre Educação do Campo e como o uso de Computador e Internet poderiam contribuir com essas comunidades e escolas.

Desde então, não mais me apartei desse movimento. Passei a participar das discussões sobre a Licenciatura e, em seguida, fui atuar na mesma como professora voluntária, isso em 2008, quando do início da primeira turma a funcionar em Brasília ${ }^{3}$. Iniciei meu trabalho como professora, em bidocência com o professor Márcio Ferreira, atuando nas Oficinas de Informática, que depois passaram à disciplina denominada Comunicação e Tecnologias da Informação por nós criada, em que, além de iniciarmos o grupo na utilização do computador e Internet, realizamos discussões acerca do uso

\footnotetext{
${ }^{3}$ A primeira turma da Licenciatura em Educação do Campo aconteceu no ITERRA, no Rio Grande do Sul, por falta de uma estrutura que comportasse os educandos quando viessem para o Tempo Escola, como era chamado o momento de aulas no campus da Universidade, quando os educandos ficam alojados na Universidade por um período de 45 a 60 dias para assistir às aulas dos componentes curriculares.
} 
de Tecnologias Digitais nos processos educativos. Ainda hoje continuamos esse nosso trabalho na LEdoC, atualmente atendendo as turmas 6, 7 e 8. É a partir dessa minha inserção na LEdoC que surge o interesse por continuar os estudos e, ao mesmo tempo, investigar o grupo em questão acerca da utilização do uso de computador e Internet em processos educativos promovidos por esses sujeitos enquanto educadores de suas comunidades de origem.

\section{Quem são os sujeitos pesquisados?}

Decidimos pesquisar a Turma 2 da Licenciatura em Educação do Campo da Universidade de Brasília - LEdoC-UnB por considerar essa turma a pioneira em termos de atendimento do público ao qual realmente se destinava a LEdoC-UnB, ou seja, educadores do campo da Região Centro-Oeste. Deixamos claro esse aspecto porque, a Turma 1 que foi a turma piloto desta Licenciatura, na verdade, não teve sua materialidade no Campus da UnB, mas no ITERRA (Instituto Técnico de Capacitação e Pesquisa da Reforma Agrária), em Veranópolis, no Rio Grande do Sul, por falta de uma estrutura que comportasse os educandos quando viessem para o Tempo Escola, como era chamado o momento de aulas no campus da Universidade, quando os educandos ficam alojados na Universidade por um período de 45 a 60 dias para participar das aulas dos componentes curriculares.

No percurso metodológico falamos mais sobre esses sujeitos.

\section{Por que realizar esta pesquisa?}

Além da problemática apresentada inicialmente e do histórico da pesquisadora, outros fatores nos levaram ao desenvolvimento este estudo. Apresentamos algumas informações que enriquecem essa justificativa e nos trazem a realidade do campo brasileiro de modo mais claro e realista. Assim, nos parágrafos que se seguem buscamos discutir alguns questionamentos que nos conduziram a esta pesquisa trazendo para o debate alguns compromissos e proposições feitos na Conferência Nacional Por Uma Educação Básica do Campo, de 1998 e no Seminário Nacional Por Uma Educação do Campo, de 2002: 
$\checkmark$ A formação docente para o uso de Tecnologias Digitais: em tempos em que a informação é um dos bens mais valiosos, nossa escola pública continua a prescindir do uso das tecnologias digitais em seu trabalho pedagógico. Essa realidade é ainda mais cruel nas escolas do campo, quando, em muitas das vezes, não existe um computador nem na secretaria para fazer a documentação da escola. No entanto, quando a escola finalmente é dotada desses recursos, às vezes é inútil porque os professores não são formados para desenvolver estratégias pedagógicas utilizando ferramentas informáticas e outras Tecnologias Digitais.

$\checkmark$ Por que não são produzidos e distribuídos livros e materiais didático-pedagógicos específicos para as comunidades campesinas em todos os níveis e modalidades de ensino? As escolas do campo no Brasil, em toda sua história, sempre tiveram que trabalhar com livros e materiais pensados e elaborados para estudantes urbanos, com características que contemplam apenas essa comunidade. Talvez, na última década, alguns livros contivessem conteúdos que tratassem do meio rural de maneira bastante geral, nunca trazendo as particularidades regionais ou culturais da localidade que os recebiam. Assim, pensamos na possibilidade de produção de materiais didático-pedagógicos pelos próprios sujeitos do campo, em suas comunidades/escolas de origem. E com as Tecnologias Digitais facilitando essa concepção e construção, pudemos imaginar esses recursos digitais como propulsores de novas práticas pedagógicas do campo e, quem sabe até, da ressignificação e construção de um novo currículo local. A partir de 2013, os educandos do $1^{\circ}$ ao $5^{\circ}$ ano do ensino fundamental que estudam em escolas públicas consideradas rurais passaram receber um material didático específico, segundo consta no site do MEC. As obras do Programa 
Nacional do Livro Didático Campo - PNLD Campo compreendem a alfabetização matemática, letramento e alfabetização, língua portuguesa, matemática, ciências, história e geografia. O diferencial consiste na possibilidade das coleções em formatos diferentes (multisseriada $\mathrm{e}$ seriada) de modo a diversificar a oferta de projetos pedagógicos aos professores. Além disso, essas coleções podem considerar as especificidades do seu contexto social, cultural, ambiental, político e econômico. A escolha e a distribuição das coleções, que são consumíveis, é trienal e integral. Porém nos questionamos: e os Anos Finais do Ensino Fundamental e o Ensino Médio, por que não são contemplados pelo PNLD Campo? Além disso, o PNLD Campo existente apresenta lacunas que acabam por não contemplar as necessidades locais das escolas: os livros são produzidos em âmbito regional, ou seja, falta de abertura para inserção de elementos da cultural local; não há inclusão obrigatória de recursos digitais; enfim, ainda há muito a se construir nesse sentido.

$\checkmark$ Os sujeitos do campo como produtores de conhecimento: os livros trazem uma concepção de conhecimento que por muito tempo se acreditou que somente quem poderia criar conhecimento, ser autor de novas ideias eram os cientistas a partir do método científico. Que fora do método científico não haveria conhecimento. E o que acontece nas comunidades tradicionais em relação a remédios à base de ervas medicinais? E as festas e crenças das comunidades do campo, o que são? E todas as demais formas de organização da vida espalhadas pelo país, no interior, em localidades remotas em que a sobrevivência, a transmissão de cultura, a saúde, a produção não ocorrem com a mediação do conhecimento científico? 
Enfim, complementamos essa justificativa pela fala de Caldart (2011) quando diz que

... a Pedagogia do Movimento, pensada desde a experiência formativa destes movimentos camponeses, ao afirmar 0 trabalho, a cultura e a luta social com sua organização coletiva como matrizes formadoras do ser humano, retoma o debate da práxis social como princípio educativo, o que exige um repensar radical dos projetos educativos, nos seus objetivos e na forma de organização do trabalho pedagógico. (CALDART, 2011, p.150).

A partir do exposto, apresenta-se o seguinte problema de pesquisa: Em que medida o acesso e a apropriação das Tecnologias Digitais no processo de formação de educadores do campo ajudam a produzir recursos educacionais contextualizados que possam provocar alterações, numa perspectiva transformadora/emancipadora, em suas práticas pedagógicas nas escolas do campo?

A partir dessa questão norteadora, temos como objetivos de pesquisa:

\section{Objetivo geral:}

- Investigar e analisar em que medida o acesso e a apropriação das Tecnologias Digitais no processo de formação de educadores do campo ajudam a utilizar e produzir recursos educacionais contextualizados que possam provocar alterações, numa perspectiva transformadora/emancipadora, em suas práticas pedagógicas nas escolas do campo.

\section{Objetivos específicos:}

- Averiguar a relação dos educadores formados pela Licenciatura em Educação do Campo - LEdoC-UnB, Turma 2, com as Tecnologias Digitais, principalmente com computador e Internet, quando de seu ingresso nesse curso.

- Pesquisar e analisar a atuação desses educadores em relação à utilização das Tecnologias Digitais em sua prática docente a partir do componente Comunicação e Tecnologias da Informação da LEdoC-UnB. 
- Verificar se e em que medida a utilização e a produção de recursos educacionais contextualizados altera e/ou pode transformar as práticas docentes desses educadores numa perspectiva emancipadora.

Assim, pensando em todas essas questões, esta investigação foi-se construindo

\begin{abstract}
Apostando na compreensão gramsciana que entende a escola como um espaço em disputa, como importante lócus de produção de contra-hegemonia aos valores da sociedade capitalista, o Movimento da Educação do Campo trabalha com a perspectiva de formar educadores camponeses que possam atuar nessas escolas como intelectuais orgânicos da classe trabalhadora (GRAMSCI, 1991), contribuindo, por sua vez, com a formação crítica dos educandos que passem por essas unidades escolares, dando-Ihes condições de compreender os modelos de desenvolvimento do campo em disputa como parte integrante da totalidade maior da disputa de projetos societários distintos entre a classe trabalhadora e a capitalista (MOLINA, 2014, pp. 267-268).
\end{abstract}

Para nos situarmos em relação ao contexto deste estudo, torna-se essencial entendermos: o que é Educação do Campo?

O surgimento da expressão "Educação do Campo", aconteceu, inicialmente, como Educação Básica do Campo no contexto de preparação da I Conferência Nacional por uma Educação Básica do Campo, realizada em Luziânia, Goiás, de 27 a 30 de julho de 1998, evento este que foi uma espécie de "batismo coletivo" da luta dos movimentos sociais e das educadoras e dos educadores do campo pelo direito à educação. Passou a ser utilizada a denominação Educação do Campo a partir das discussões do Seminário Nacional realizado em Brasília de 26 a 29 de novembro de 2002, decisão posteriormente reafirmada nos debates da II Conferência Nacional, realizada em agosto de 2004.

Este movimento de Educação do Campo está ajudando a produzir um novo olhar para o campo. E faz isso em sintonia com toda uma nova dinâmica social de valorização deste território e de busca de alternativas para melhorar a situação de quem vive e trabalha nele. Uma dinâmica que vem sendo construída por sujeitos que já não aceitam que o campo seja lugar de atraso e de discriminação, mas sim consideram e 
lutam pra fazer dele uma possibilidade de vida e de trabalho para muitas pessoas, assim como a cidade também deve sêlo; nem melhor nem pior, apenas diferente; uma escolha. (UnB-FUP, 2009a, p. 5)

É de suma importância fazer esta contextualização tendo em vista que a Licenciatura em Educação do Campo, pelas especificidades que a compõem, carece de uma atenção especial às questões relativas aos recursos utilizados nos processos educativos, que quase sempre não são produzidos para e pelos sujeitos do campo e, normalmente, trazem subjacentes ideologias que não casam com a identidade cultural e social dos sujeitos envolvidos. Sobre este tema Arroyo traz uma reflexão bastante pertinente, quando diz que:

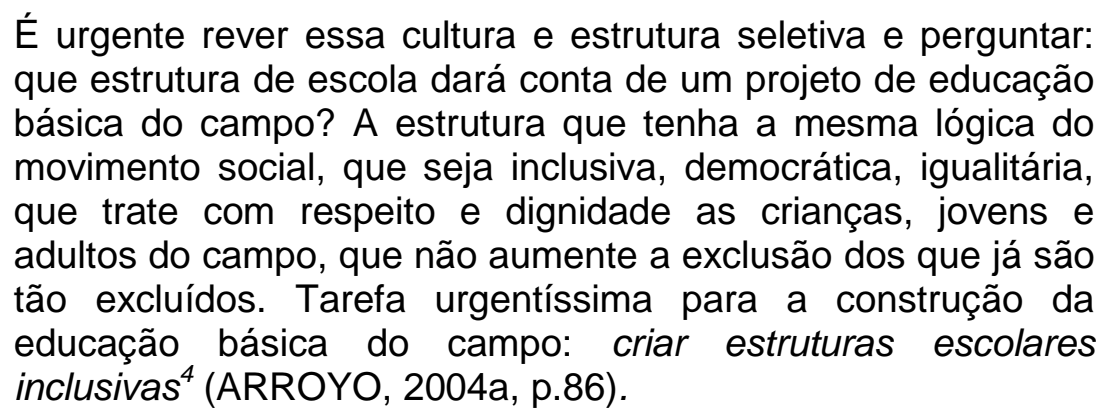

Enxergamos, aqui, que quando Arroyo cita a necessidade de rever as estruturas, fala não somente dos prédios físicos, mas também de tudo aquilo que circunda a escola do campo: prédio, distância da escola em relação aos educandos, educadores da comunidade atendida, materiais didáticopedagógicos, enfim, tudo que é inerente aos processos educativos vivenciados na instituição escolar. Ele deixa isto bem claro, quando diz que "a questão que teremos de nos colocar é: que escola, que concepção e prática pedagógica darão conta do direito à educação básica desses sujeitos do campo" (ARROYO, 2004a, p.73). Tem havido, segundo o autor, um descompasso marcante entre o avanço da consciência dos direitos, promovido pela mobilização dos movimentos sociais organizados e a educação escolar propriamente dita. Ou seja, os sujeitos do campo sabem de seus direitos, mas esses thes são negados por uma série de fatores, dentre eles, a falta de formação de educadores para atuação nestas escolas do campo.

\footnotetext{
${ }^{4}$ Grifo do autor.
} 
O currículo da escola do campo precisa também ter como foco os saberes que preparam para a produção e o trabalho, que preparam para a emancipação, para a justiça, os saberes que preparam para a realização plena do ser humano como humano (ARROYO, 2004a, pp. 82-83) e que the dê o direito de se constituir cidadão que deseja continuar no campo e ter possibilidade de sobreviver e viver com dignidade a partir do seu próprio trabalho e da sua própria produção. Também sobre a questão dos saberes nos falam Santos, Meneses \& Nunes quando arrazoam que:

Ao longo dos séculos, as constelações de saberes foram desenvolvendo formas de articulação entre si e hoje, mais do que nunca, importa construir um modo verdadeiramente dialógico de engajamento permanente, articulando as estruturas do saber moderno/científico/ocidental às formações nativas/locais/tradicionais de conhecimento. O desafio é, pois, de luta contra uma monocultura do saber, não apenas na teoria, mas como uma prática constante do processo de estudo, de pesquisa-ação. Como Nandy (1999) refere, o futuro não está no retorno a velhas tradições, pois nenhuma tecnologia é a neutra: cada tecnologia carrega consigo o peso do modo de ver e estar com a natureza e com os outros. O futuro encontra-se, assim, na encruzilhada dos saberes e das tecnologias. (2005, p. 54)

A escola do campo, na maioria dos casos, ainda carece do uso do computador e da Internet por diversos fatores: falta de equipamentos e conectividade, ausência de formação dos docentes para utilização desta tecnologia, descaso dos governos em relação às escolas do campo por acharem que no campo não seja necessária a utilização de redes digitais, caindo no debate simplista de que as "escolinhas rurais" não precisam disto. É preciso dotar de oportunidades de conhecimento do mundo e de desenvolvimento as comunidades campesinas, e supõe-se que ciberespaço possa contribuir com este diálogo.

É necessário pensarmos em estratégias que promovam este desenvolvimento rural sem que os sujeitos do campo tenham que abandonar seu lócus de vivência, estudo e produção para ir à busca destes conhecimentos. Neste sentido, indaga-se: o acesso às informações pela Internet pode trazer às práticas pedagógicas inovações que melhorem os processos educativos, além de melhorar a vida no campo, seu modo de 
trabalho, técnicas de plantio e cultivo autossustentáveis e ecologicamente corretas?

Este trabalho se desenvolve em três grandes capítulos destrinchados em tópicos outros e mais o capítulo das conclusões.

No primeiro capítulo delineamos o percurso metodológico traçado pela pesquisadora em busca das respostas aos objetivos de pesquisa propostos. Os tópicos ou subcapítulos tratam dos elementos essenciais à realização da pesquisa e das opções feitas pela pesquisadora. Assim, são subcapítulos relativos ao percurso metodológico: sujeitos da pesquisa; a opção pela pesquisa qualitativa e também pela pesquisa-ação; quais os dispositivos de pesquisa utilizados: questionário, diário de campo, observação participante, entrevista estruturada, diálogos pedagógicos; mostramos o delineamento da pesquisa; e, finalmente, como foram feitas as análises e discussões.

No capítulo dois tratamos do referencial teórico utilizado como base teórica e epistemológica da pesquisa. Nosso referencial teórico versa sobre os fundamentos relativos a: Educação do Campo; Escolas do Campo; Formação de Educadores do Campo: a Licenciatura em Educação do Campo na UnB (LEdoC - UnB); Tecnologias Digitais, Letramento Digital e Recursos Educacionais Abertos; Letramento digital e educadores do campo ;

Comunicação e Tecnologias da Informação - a formação para uso das Tecnologias Digitais em processos educativos; Síntese das aulas em CTI; História e conceito de REA; Recursos Educacionais Abertos e Educação do Campo.

No capítulo seguinte, fazemos as análises e traçamos os resultados da pesquisa e fizemos isso sob o título Trilhar caminhos, tecer compreensões e desenvolve-se sob os seguintes subtítulos: Um sucinto diagnóstico sobre a Turma 2 e as Tecnologias Digitais; Compreensões de todo um percurso, desafios às transformações na Escola do Campo; Políticas públicas e exclusão digital no campo; Instrumentalização, formação e interdisciplinaridade; Tecnologias Digitais e poder; Desvantagens do uso do computador e da Internet; Ensaios de práticas emancipatórias; Escolas do Campo e formação docente; Tecnologias Digitais e coordenação pedagógica; Tecnologias Digitais e Educação do Campo: um desafio; Sujeitos do campo, relações educativas e 
Tecnologias Digitais; Maior horizontalidade na relação educando-educador; Maior horizontalidade na relação educando-conhecimento; Facilidades e dificuldades no uso de Tecnologias Digitais; Recursos Educacionais Abertos e Educação do Campo: potencialidades à vista.

No quarto e último capítulo concluímos a pesquisa, falando acerca dos resultados e fazendo considerações finais e recomendações.

Esperamos que esta pesquisa contribua com outros estudos relacionados aos temas e que possa suscitar novos desafios acadêmicos ou não. Boa leitura! 


\section{CAPÍTULO 1 - PERCURSO METODOLÓGICO}

Para falar em método de pesquisa e produção de conhecimento, primeiramente é preciso falar qual nossa visão de mundo e que lente sociológica utilizamos para visualizar e analisar a realidade em que está inserido nosso objeto de estudo.

Entendemos ser importante deixar claro que a abordagem utilizada neste trabalho é aquela em que a realidade social é vista por meio de suas contradições. Em que a realidade está em constante transformação, não existindo, portanto, regimes sociais imutáveis, nem princípios eternos. Falamos sob a perspectiva do Materialismo Histórico Dialético, pois a partir dele temos clareza do mundo (a matéria) como processo histórico em constante movimento de desenvolvimento (dialeticidade), constituído na unidade de contradições que lhe são temporalmente específicas e que, na lei da luta dos contrários, garantem a possibilidade concreta de transformação (historicidade).

Cabe ainda esclarecer, pois, em nossa perspectiva teórica, que a transformação é um processo inerente ao desenvolvimento de todo e qualquer fenômeno, processo ou objeto da realidade, caracterizando o estágio da resolução de todas as contradições específicas desse desenvolvimento.

Guiados pelas leis e categorias do Materialismo Dialético, que buscam explicações coerentes, lógicas e racionais para os fenômenos da natureza, da sociedade e do pensamento; pelo Materialismo Histórico, que é a expressão do primeiro aplicada à analise da sociedade de sua evolução histórica e da prática social dos homens, no desenvolvimento da humanidade, e pela Economia Política, temos convicção na possibilidade concreta da transformação das condições materiais que estão hoje a nos roubar a humanidade a cada dia em que se repetem as práticas opressoras, alienadoras e exploratórias que competem à lógica de existência e persistência do capital.

Confiamos nesses fundamentos como a teoria necessária à consciência dos seres humanos para que sejam inevitáveis as práticas transformadoras. Se nos lançarmos à prática sem que se tenha desenvolvido em nós uma consciência crítica sobre a realidade, corremos o sério risco de resultar ativismos infrutíferos. Da mesma forma, seremos acusados com justiça de verbalismo se, munidos de um arsenal teórico libertador, nos acomodamos e não concretizamos a prática 
transformadora que é necessariamente o processo imediato do conhecimento teórico libertador (DAMO et. al., 2012, p.4).

Concordando com Damo e colaboradores (2012), acreditamos no Método Materialista Dialético, proposto por Karl Marx como fundamento para a análise da realidade, mostra-se capaz de conduzir à transformação, pois as categorias e leis da dialética materialista expressam o movimento de desenvolvimento de todas as coisas, processos e fenômenos da realidade. Assim, conscientes de que a teoria forma-se a partir da compreensão da prática social (TRIVIÑOS, 2008, p.51), sabemos que somente uma teoria que compreenda a prática com o maior aprofundamento possível poderá resultar em ações transformadoras.

Realizar uma análise da realidade dos sujeitos, acerca de seu trabalho enquanto educadores do campo e responsáveis por promover a transformação a partir das contradições vivenciadas e observadas, com certeza nos mostra que as causas são, todas elas, ramificações da forma como estamos produzindo nossa existência material dentro do modo de produção capitalista.

Nenhum processo eficaz de transformação poderá ocorrer no âmbito das relações sociais e entre seres humanos e o meio natural sem que haja uma clareza, fruto da formação da consciência crítica, de como surgiu e está se desenvolvendo o contexto por nós hoje vivenciado como "o modo capitalista de existir" e transformar a natureza a partir de uma lógica voltada, não para atender as necessidades humanas, mas o lucro que mantém o capital (DAMO et.al., 2012, pp.4-5).

Precisamos nos atentar para o fato de que as ações conservadorasreprodutivistas adotadas no âmbito da educação nada contribuem para a transformação daquilo que a realidade está a nos dizer que precisamos transformar, como a Educação do Campo, por exemplo. Pelo contrário, se continuarmos a realizar uma educação subjugada à lógica do capital, continuaremos a serviço dele. A esse respeito, nos diz Bonilla que

A escola atual trabalha no sentido da reprodução e transmissão do modelo hegemônico, fechada à exterioridade. Mesmo quando o modelo pedagógico adotado admite as diferenças, trabalha no sentido de lapidar as arestas e conduzir a uma unidade, a uma identidade hegemônica. (BONILLA, 2005, p.77).

A compreensão do método Materialista Dialético possibilita-nos reconhecer que o capital permeia ideologicamente todas as instâncias da vida 
social e também aquelas entre seres humanos. Sendo assim é frequente a distorção do que sejam realmente as "práticas transformadoras" nos processos educativos, principalmente no que se refere ao uso de Tecnologias Digitais. Um conjunto de práticas transformadoras pressupõe romper com a forma como estamos nos produzindo materialmente em sociedade, ou seja, exige a superação das contradições próprias de nossa ordem social e não sua continuidade (DAMO et.al., 2012, p.5).

Mas como abandonar essa lógica? Como prescindir de algo que hoje faz parte do modo de vida, da forma de comunicação e até das relações pessoais, como as Tecnologias Digitais? Será que o melhor a fazermos é ignorar a Web e o quanto ela tem participado da sociedade atual? Ou poderíamos utilizar as Tecnologias Digitais e a Web para promover a revolução necessária, como têm feitos diversos movimentos sociais espalhados pelo Brasil e pelo mundo? Questões, como essas permearam nossas discussões junto aos educadores do campo em formação durante todo este trabalho.

Para que se entenda a pesquisa que ora apresentamos, faz-se relevante entender quem são os sujeitos da mesma.

\subsection{Sujeitos da pesquisa}

A segunda turma da LEdoC-UnB prestou vestibular para ingresso no curso em 27 de julho de 2008 (SANTOS, 2013, p. 37). Essa turma foi, inicialmente, formada por cinquenta e cinco jovens de toda região Centro Oeste: Goiás, Mato Grosso do Sul, Minas Gerais, DF e Entorno e desses, quarenta e dois concluíram o Curso juntos.

Para participar do vestibular, alguns aspectos foram exigidos dos futuros candidatos: as inscrições foram feitas mediante a apresentação de carta de intenções redigida de próprio punho; entrega de um documento comprobatório do envolvimento do candidato com o campo, documento esse redigido e assinado por movimento social, sindicato ou associação da comunidade de origem; comprovação de trabalho desenvolvido em escolas do e no campo e/ou residência no campo como assentado da reforma agrária, comunidades remanescentes de quilombos, comunidades tradicionais ou agricultura familiar. Os candidatos passaram por uma prova de vestibular 
aplicada pelo CESPE/UnB que continha conteúdos obrigatórios do vestibular e redação, como qualquer vestibular. No entanto, houve a especificidade da prova ter questões relacionadas ao campo e a redação tratando também desse tema.

Os estudantes eram de Movimentos Sociais (MST, MMC, MTD, MLT, CONTAG), de Quilombos, professoras e professores das escolas do campo que não tinham o nível superior. Na turma estavam presentes duas comunidades Quilombolas Kalunga (Engenho II e Prata) e doze assentamentos/pré-assentamentos/acampamentos (Vale da Esperança, Palmeira II, Brejão, Itaúna, Terra Conquistada, Sol Nascente, Palmares, Mãe das Conquistas, Índio Galdino, Areias, Nova Conquista e Antônio Conselheiro). (NASCIMENTO, 2013, pp. 73-74).

Aproximadamente $38 \%$ da Turma 2 tinham vínculo com os movimentos sociais, fator determinante de um perfil de estudante com formação política e experiência de organização coletiva (BARBOSA, 2012, p. 121).

Os educandos denominaram a Turma 2 de Turma Andréia Pereira dos Santos, que foi militante do setor de educação do MST. Andréia também foi professora de alguns dos estudantes da turma, educadora popular que teve sua história escrita com luta e determinação. Uma mãe excepcional que perdeu a vida em decorrência de complicações do parto de sua $3^{\text {a }}$ filha. Esta foi uma homenagem mais que merecida a alguém que, de várias maneiras, contribuiu para que o curso existisse, conforme nos conta Santos (2013, p. 40).

A distribuição de gênero dos egressos, ou seja, ao final do curso, era de $45 \%$ de homens e $55 \%$ de mulheres.

Cabe-nos informar ao leitor que neste trabalho chamamos esses sujeitos de "docentes em formação" ou "educadores em formação", visto que a maioria deles já atuava como docente quando de seu ingresso na referida Licenciatura. No entanto, para não ficar muito repetitivo e também para fins didáticos, em determinados momentos os trataremos como educandos ou estudantes, porque também o eram no momento do curso.

Também precisamos informar que o convite para a entrevista com egressos foi enviado para todos aqueles dos quais dispúnhamos de contatos, 
no entanto, alguns fatores nos impediram de contatar vários deles: dadas as características de itinerância daqueles que ainda não foram assentados, ou seja, ainda residem em acampamentos (são locais de ocupação, mas que ainda não foram destinados à Reforma Agrária, então esses não são fixos); outros são assentados, mas residem em outros estados, já que a Turma 2 era composta de moradores de todo o Centro-oeste e mais dois cursistas de Buritis de Minas Gerais que faz parte da região do Entorno do Distrito Federal; alguns dos egressos continuam morando na mesma localidade, mas trocaram de telefone e/ou e-mail; ainda existem aqueles que após concluírem a graduação, pararam de utilizar o e-mail porque não conectividade em suas comunidades; finalmente, alguns não tinham como agendar a entrevista por causa de outros compromissos e como nosso tempo era exíguo não havia tempo hábil para marcarmos em outras datas. Desse modo, a entrevista foi realizada com onze egressos, que foram aqueles que não se enquadravam em nenhuma das situações descritas acima. Concluímos, portanto, que o grupo não foi escolhido por critério algum, o que os selecionou foram as condições em que se encontravam no momento da entrevista, dada a realidade diversa do campo brasileiro.

\subsection{Pesquisa Qualitativa}

A abordagem qualitativa surgiu como uma opção interessante e mais coerente com o delineamento da pesquisa que ora apresentamos. Para AlvesMazzotti \& Gewandsznajder (2004), as investigações qualitativas, por sua diversidade e flexibilidade não admitem e nem necessitam de regras precisas, aplicáveis a uma gama de casos, principalmente a pesquisas de cunho quantitativo.

Nesta pesquisa, particularmente, dadas as características do trabalho desenvolvido, a abordagem qualitativa foi preferida por trabalharmos com uma comunidade acadêmica específica em que trabalhamos com a obtenção de dados descritivos, obtidos no contato direto da pesquisadora com a situação estudada. A ênfase maior foi no processo desenvolvido e não no produto final e houve grande preocupação em retratar a perspectiva dos participantes, conforme nos dizem Bodgan \& Bilken (1982, apud LÜDKE \& ANDRÉ, 1986, 
p.13) e André (2003) acerca das principais características dessa abordagem. São elas:

I. a pesquisa qualitativa tem o ambiente natural como sua fonte direta de dados e o pesquisador como instrumento-chave;

II. as informações coletadas são predominantemente descritivas;

III. os pesquisadores qualitativos estão preocupados com os processos e não simplesmente com os resultados finais e o produto;

IV. o significado, a maneira própria com que as pessoas veem a si mesmas, as suas experiências e o mundo que as cerca são focos de atenção de especial atenção do pesquisador;

V. a análise das informações tende a seguir um processo indutivo.

Diante da complexidade do nosso objeto, justifica-se a pesquisa qualitativa e precisamos, assim, estar atentos, o tempo todo, aos três princípios de importantes consequências metodológicas nos quais se apoia a epistemologia qualitativa segundo González Rey (2005, p. 31-32), que são:

- o conhecimento é uma produção construtivo-interpretativa - o conhecimento não é uma soma de fatos definidos por constatações imediatas do momento empírico. Seu caráter interpretativo é gerado pela necessidade de dar sentido a expressões do sujeito estudado, cuja significação para o problema objeto de estudo é só indireta e implícita. Ainda para González Rey (2005), a interpretação é um processo em que o pesquisador integra, reconstrói e apresenta, em construções interpretativas, diversos indicadores obtidos durante a pesquisa, os quais não teriam nenhum sentido se fossem tomados isoladamente, como constatações empíricas;

- caráter interativo do processo de produção do conhecimento essa característica da abordagem qualitativa enfatiza que as relações pesquisador-pesquisado são uma condição para o desenvolvimento das pesquisas nas Ciências Humanas e que o interativo é uma dimensão essencial do processo de produção de 
conhecimentos, um atributo constitutivo do processo de estudo dos fenômenos humanos;

- significação da singularidade como nível legítimo da produção do conhecimento - segundo González Rey (2005), a singularidade foi historicamente desconsiderada quanto à sua legitimidade como fonte de conhecimento científico; mas na pesquisa da subjetividade adquire importante significação qualitativa, que impede identificá-la com o conceito de individualidade. A singularidade, para o autor, se constitui como realidade diferenciada na história da constituição subjetiva do indivíduo. O conhecimento científico, a partir desse ponto de vista, não se legitima pela quantidade de sujeitos a serem estudados, mas pela qualidade de sua expressão.

Por fim, cabe ainda ressaltar, que esta pesquisa trilhou o percurso entre o empírico e o teórico, o que possibilitou desdobramentos que puderam contribuir para a redefinição do próprio projeto e das estratégias metodológicas.

\subsection{Pesquisa-ação}

Para subsidiar o desenvolvimento desta proposta optamos por utilizar o método da pesquisa-ação, pois, este trabalho aconteceu em um contexto em que os educadores em formação da Licenciatura em Educação do Campo e sua comunidade de origem foram os protagonistas desta construção desde a criação da proposta, seu desenvolvimento, reflexões coletivas, caminhos percorridos, quase tudo pactuado com todo o grupo envolvido, como construtores ativos de uma pesquisa que teve como objetivo subsidiar a comunidade para que os próprios sujeitos buscassem refletir sobre de que forma os conhecimentos construídos poderiam ser utilizados como instrumentos para futuras conquistas e ações em prol do coletivo, de suas lutas, histórias e conquistas.

Thiollent (2011) explica que na fase de definição da pesquisa-ação, surge uma condição necessária que consiste na elucidação dos objetivos e, em particular, das relações existentes entre os objetivos de pesquisa e os objetivos de ação. Ele explica que a pesquisa-ação consiste no relacionamento entre esses dois objetivos, o prático, que contribuiu para um melhor equacionamento 
do problema considerado como central na pesquisa, levantando soluções e propostas de ações correspondentes às "soluções" para auxiliar o agente ou o sujeito na sua atividade transformadora da situação, que deve ser visto com realismo, ou seja, sem exageros na definição das soluções alcançáveis; e o objetivo de conhecimento, que consiste em obter informações que seriam de difícil acesso por meio de outros procedimentos, aumentando o conhecimento de outras situações (representações, capacidades de ação e de mobilização e etc.).

Segundo Barbier (2004), não há pesquisa-ação sem participação coletiva. É preciso compreender o termo "participação" em seu mais amplo sentido: não se pode entender do que nos interessa sem que, de fato, sejamos parte integrante da pesquisa, sem que estejamos envolvidos direta e pessoalmente pela experiência, na integralidade de nossa vida emocional, imaginativa, sensorial e racional.

Fazer pesquisa-ação implica em se entregar de corpo e alma a uma experiência que realmente tem um significado, como diz Barbier (2004), emocional, racional e até espiritual para nós. Deve-se ao fato de acreditarmos que nossa relação com quem pretendemos caminhar tem mais que um simples desfecho ou conclusão centrado no academicismo, mas volta-se para nossa essência, do que realmente acreditamos e o que realmente queremos para nossas vidas, espiritual e ideologicamente. Para Barbier,

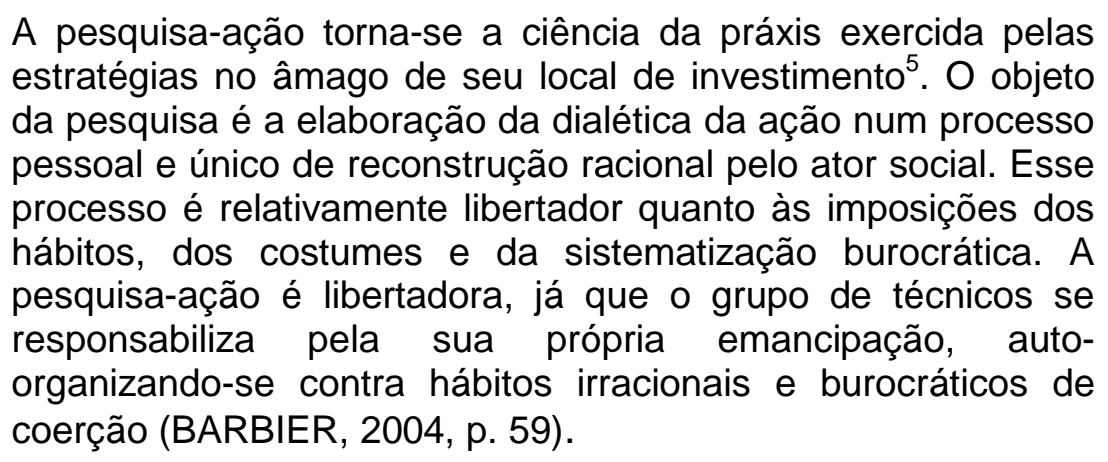

Thiollent (2011) lembra que do ponto de vista científico, a pesquisaação é uma proposta técnica e metodológica que oferece alternativas para

\footnotetext{
${ }^{5} \mathrm{Na}$ linguagem psicanalítica, investimento significa o fato de investir; e investir, por sua energia psíquica em (uma atividade, um objeto). (N.T).
} 
organizar a pesquisa social aplicada sem os excessos da postura conservadora ao nível da observação, da coleta de dados e da experimentação:

\begin{abstract}
Podemos considerar que, internamente ao processo de pesquisa-ação, encontramos qualidades que não estão presentes em processos convencionais. Por exemplo, podemos captar informações geradas pela mobilização coletiva em torno de ações concretas que não seriam alcançáveis nas circunstâncias da observação passiva. Quando as pessoas estão fazendo alguma coisa relacionada com a solução de um problema seu, há condição de estudar esse problema num nível mais profundo e realista do que no nível opinativo ou representativo no qual se reproduzem apenas imagens individuais e estereotipadas (THIOLLENT, 2011, p. 30).
\end{abstract}

Com relação à formulação do problema, a pesquisa-ação não tem que se preocupar, a priori, com a definição de hipóteses e formulações teóricas e muito menos traduzi-las em instrumentos operatórios e padronizados como questionários, testes. A pesquisa-ação reconhece que o problema nasce, em um contexto preciso, das angústias e autocríticas de um grupo. O pesquisador não o provoca, mas constata-o e seu papel consiste em ajudar a coletividade a determinar todos os detalhes mais cruciais ligados ao problema, por uma tomada de consciência dos atores do problema em questão na ação coletiva (BARBIER, 2004, p. 54).

Apesar disso, elegemos algumas categorias a priori e as demais a posteriori, conforme foi surgindo a necessidade e a repetição das ocorrências. Isso está evidenciado mais à frente, quando falamos das análises e conclusões.

Nada caminha se não houver uma entrega coletiva e uma clareza por parte de todos e todas de que a relação vai muito além de puros dados quantitativos. Nada é definido e as respostas dependem de interpretações e de análises que partem do grupo coletivo, assegurando uma linguagem acessível a todos (as), tendo como um dos traços principais a ação-reflexão, como processo contínuo de comunicação dos resultados da investigação entre os membros nela envolvidos, objetivando a análise de suas reações.

Para Barbier (2004, p. 60), a pesquisa-ação emancipatória implica três pontos essenciais: 
$\checkmark$ pressupõe-se que os pesquisadores técnicos (por exemplo, os docentes de uma escola) percebam o processo educativo como um objeto passível de pesquisa;

$\checkmark$ pressupõe-se que esses pesquisadores percebam a natureza social e as consequências da transformação em curso;

$\checkmark$ pressupõe-se, enfim, que eles compreendam a pesquisa mesma como uma atividade social e política, portanto ideológica.

O mesmo autor defende que se utilizem múltiplas técnicas de pesquisa (diário, registros audiovisuais, análise de conteúdo, dentre outras). O método da pesquisa-ação inspirado em Lewin é o da espiral com suas fases: de planejamento, de ação, de observação e de reflexão, depois de um novo planejamento da experiência em curso. Para Barbier (2004, p. 60), a exatidão da pesquisa-ação repousa na coerência lógica empírica e política das interpretações propostas nos diferentes momentos da ação.

No caso desta investigação, essas fases foram se entremeando de acordo com os Tempos Escola e os Tempos Comunidade, o que permitiu exercitar os conhecimentos construídos nas aulas de CTI e trazer as impressões sobre suas aplicações nas escolas de inserção orientada. Além disso, as anotações do diário de campo, os registros audiovisuais das aulas em Tempo Escola e dos momentos em Tempo Comunidade e a análise de conteúdo permitiram a triangulação para melhor confiabilidade da pesquisa.

Barbier argumenta que o espírito da pesquisa-ação consiste em uma abordagem em espiral ${ }^{6}$ que a todas utiliza. Para ele, significa que todo o avanço em pesquisa-ação implica o efeito recursivo em função de uma reflexão permanente sobre a ação (BARBIER, 2004, p. 117).

A seguir, delineamos os procedimentos e instrumentos de pesquisa para que o leitor compreenda melhor o processo.

\footnotetext{
${ }^{6}$ Destaque do autor.
} 


\subsection{Dispositivos de pesquisa}

De acordo com Barbier (2004), a pesquisa-ação utiliza os mesmos instrumentos de pesquisa das Ciências Sociais, mas adota ou inventa novos (2004, p. 56).

Neste estudo, a teoria considerada como o cenário da produção de conhecimentos, como assegura González Rey (2005), influi não só na modificação sobre o lugar do empírico, mas na metodologia de pesquisa como um todo. Nesse sentido, como pesquisadora, atentei menos para o acúmulo de dados e procurei envolver-me mais com a produção de ideias e explicações a partir dos indicadores construídos no curso da pesquisa. Para esse fim, o instrumento deixa de ser fonte de produção de dados válidos, para converterse em fonte de informação sobre o estudo. Informação que só adquire sentido dentro do conjunto daquelas produzidas pelos sujeitos estudados. Os instrumentos podem ser vistos também como procedimentos encaminhados a estimular a expressão dos sujeitos pesquisados, são, simplesmente, indutores de informação que não definem o sentido final dela.

A informação que um instrumento de pesquisa proporciona, com frequência, encontra seu sentido, primeiro, no cenário dos sujeitos estudados e são as construções teóricas e as ideias que se desenvolvem nos marcos de seu estudo as que podem adquirir sentido no marco da teoria geral adotada. As categorias, reflexões e ideias que aparecem diante do estudo do singular estão mediadas e são afetadas de formas diferentes pelo marco teórico geral, mas não são definidas de forma direta por ele, porém constituem o produto de uma combinação complexa de fatores (GONZÁLEZ REY, 2005).

Os instrumentos são ferramentas interativas, não uma via objetiva geradora de resultados capazes de refletir diretamente a natureza do estudado, independentemente do pesquisador. O instrumento, de acordo com González Rey (2005), é suscetível de multiplicidade de usos dentro do processo investigativo, que não se limitam às primeiras expressões do sujeito diante dele. O ideal é que se devolva aos sujeitos o material escrito por eles em diferentes instrumentos para que se organizem os diálogos, mais significativos que a informação proporcionada originalmente pelo instrumento. É claro que esse processo de devolução e discussão acerca do anotado nem sempre 
poderá se efetivar devido ao prazo da pesquisa, mas isto será feito naqueles instrumentos em que se fizer necessário, como nas atas de reunião, por exemplo. No caso desta pesquisa, pudemos devolver aos sujeitos suas reflexões individuais e elaborar as reflexões coletivas com eles a partir de suas sínteses. Também fizemos a devolução dos resultados do questionário diagnóstico, mostrando aos educadores em formação as sínteses de suas comunidades em relação aos meios de comunicação e transporte. Nos demais procedimentos e instrumentos, infelizmente, não tivemos tempo hábil para fazê-lo.

Os instrumentos escritos não representam informações mais legítimas que as obtidas por outras fontes; a informação reportada por eles tem o mesmo 'status' que a procedente de outras fontes da pesquisa: todas são vias de definição de indicadores, que são relacionados pelo pesquisador no processo da construção teórica. Entre as funções gerais dos instrumentos escritos, está a descentralização da intencionalidade do sujeito na produção de informação, pois eles facilitam o contato do sujeito com novas zonas de sua experiência que estimulam a aparição de reflexões e emoções que, por sua vez, conduzem a novos níveis de produção de informação, tanto nos diferentes sistemas dialógicos constituídos na pesquisa, como nos instrumentos utilizados (GONZÁLEZ REY, 2005. p.83).

Nesta investigação, utilizamos como instrumentos de pesquisa: questionários e diários de campo. E como procedimentos, observação participante, entrevista estruturada e diálogos pedagógicos com análise de conteúdo. A saber:

\subsubsection{Questionário}

O questionário é um instrumento de coleta de dados com questões a serem respondidas por escrito sem a intervenção direta do pesquisador. Normalmente anexa-se, no início, uma folha explicando a natureza da pesquisa, sua importância e a necessidade de que o sujeito responda de forma adequada às questões (MOROZ \& GIANFALDONI, 2006).

O questionário deve ser cuidadosamente planejado, de forma que as questões especifiquem claramente o conteúdo que se pretende seja abordado pelo sujeito. A entrevista tem a vantagem de envolver uma relação pessoal entre pesquisador/sujeito, o que facilita um maior esclarecimento de pontos 
nebulosos. Porém, se por um lado a entrevista tem a vantagem de maior flexibilidade em relação ao questionário, esse tem a vantagem de poder ser utilizado em um grande número de pessoas ao mesmo tempo.

As perguntas mais livres são aquelas que menos limites impõem ao sujeito, contrariamente as perguntas estruturadas cujos limites são impostos pelo pesquisador. Sejam elas livres (abertas) ou estruturadas, a previsão de análise tem função essencial: no caso das questões estruturadas, é a partir delas que as opções de resposta são formuladas; no caso das questões livres, é, ainda, a partir da previsão de análise que o roteiro de entrevista e elaborado.

Nesta investigação, o objetivo da utilização questionário foi o de fazer um diagnóstico ${ }^{7}$, conhecer sobre a trajetória de vida dos educandos, sua familiaridade com o computador, seus interesses e perspectivas com relação ao desenvolvimento da pesquisa, sua disposição ou não em participar do processo, enfim, fazer um diagnóstico dos conhecimentos dos docentes em formação envolvidos na pesquisa. Essas informações possibilitaram realizar os planejamentos a partir das possibilidades, potencialidades e dificuldades de cada um e também do coletivo.

\subsubsection{Diário de campo}

$\mathrm{Na}$ pesquisa qualitativa, o registro das informações representa um processo complexo, não exclusivamente pela importância que nesse tipo de investigação adquirem o sujeito e o investigador, mas também pelas dimensões explicativas que os dados podem exigir (TRIVIÑOS, 2008).

Os pesquisadores usam, com diferente nível de abrangência, a noção de "anotações de campo". Pode ser entendida como todo o processo de coleta e análise de informações, isto é, ela compreenderia descrições de fenômenos sociais e físicos, explicações levantadas sobre as mesmas e a compreensão da totalidade da situação em estudo. Este sentido tão amplo faz das anotações de campo uma expressão quase sinônima de todo o desenvolvimento da pesquisa.

\footnotetext{
${ }^{7}$ Apêndice A.
} 


\subsubsection{Observação participante}

A técnica de observação participante realiza-se por meio do contato direto do pesquisador com o fenômeno observado para obter informações sobre a realidade dos atores sociais em seus próprios contextos. O observador, como parte do contexto de observação, estabelece uma relação face a face com os observados. Nesse processo, ele, ao mesmo tempo, pode modificar e ser modificado pelo contexto. Segundo Minayo (1999), a relevância dessa técnica reside no fato de podermos captar uma variedade de situações ou fenômenos que não são obtidos por meio de perguntas, uma vez que, observados diretamente na própria realidade, transmitem o que há de mais imponderável e evasivo na vida real.

Nesta pesquisa, os momentos de observação se deram tanto nos momentos de Tempo Escola, nas aulas de CTI, quanto nos momentos de Tempo Comunidade, quando os docentes em formação colocavam em prática os conhecimentos construídos no Tempo Escola. Durante o Tempo Comunidade esses sujeitos realizam a Inserção Orientada na Comunidade $I O C$ e a Inserção Orientada na Escola - IOE, momentos em que são colocados em prática os conhecimentos construídos tanto no TE quanto no TC, nas discussões com as famílias e com os colegas de curso.

$\mathrm{Na}$ IOE cada docente em formação participa da escola escolhida por ele/ela em atividades que vão desde a coordenação pedagógica realizada pelo coletivo de professores daquela escola, a planejamento das aulas, de atividades extraclasse, de momentos de culminância de projetos ou mesmo dos próprios projetos, enfim, esse é o momento em que a escola abre suas portas para receber os graduandos da LEdoC e, ao mesmo tempo, para receber apoio da Universidade. Nos momentos de IOE e de IOC, geralmente, os educadores em formação estão acompanhados de um ou mais docente da UnB, que participa, igualmente, dessas atividades. Foi, também, nesses momentos que estivemos juntos coletando informações para esta pesquisa.

Também foram momentos em que pudemos realizar a observação participante os seminários de integração e outros eventos em que os docentes em formação tiveram participação e se utilizaram das ferramentas informáticas 
e Tecnologias Digitais de um modo geral para fazer apresentações, demonstrações, etc.

\subsubsection{Entrevista estruturada}

Podemos entender por entrevista estruturada, conforme nos diz Triviños (2008), aquela que parte de certos questionamentos básicos apoiados em teorias gerais e hipóteses, que interessam à pesquisa e que, em seguida, oferecem amplo campo de interrogativas, fruto de novas hipóteses que vão surgindo à medida que se recebem as respostas do informante. Desta maneira, o informante, seguindo espontaneamente a linha de seu pensamento e de suas experiências dentro do foco principal colocado pelo investigador, começa a participar na elaboração do conteúdo da pesquisa (TRIVIÑOS, 2008, p.146).

$\mathrm{Na}$ pesquisa-ação, a entrevista, sobretudo a não-formal, é muito preciosa no diálogo. De modo geral, as entrevistas qualitativas são pouco estruturadas, sem um fraseamento e uma ordem rigidamente estabelecidos para as perguntas, assemelhando-se a uma conversa. Quando existe um clima favorável, por meio da entrevista, o pesquisador pode ouvir e aprender, tendo a chance de dialogar em situação "face a face" com uma pessoa. Também pode aprender muito sobre a ação e captar importantes reflexões para compreender o impacto das estratégias do grupo. Certas falas podem ser ditas entre duas pessoas, mas não em grupo. Evidentemente, é preciso assegurar-se que essas informações poderão ser utilizadas, pedindo as permissões necessárias; em certos casos, o entrevistado exigirá anonimato. No caso desta investigação, optamos por manter esse anonimato para não gerar nenhum tipo de constrangimento aos pesquisados.

Barbier (2004) afirma que o pesquisador deve saber sentir o universo afetivo, imaginário e cognitivo do outro para "compreender do interior" as atitudes e os comportamentos, o sistema de ideias, de valores, de símbolos e de mitos, o que ele também denomina de escuta sensível. Para o autor, a escuta sensível apoia-se na empatia. Ela reconhece a aceitação incondicional do outro, não julga, não mede, não compara. Ela compreende sem, entretanto, aderir às opiniões ou se identificar com o outro, com o que é enunciado ou praticado. 
Para Barbier (2004) é preciso, saber apreciar o "lugar" diferencial de cada campo das relações sociais para poder escutar sua palavra ou sua capacidade criadora. O autor arrazoa que a escuta sensível começa por não interpretar, para suspender todo julgamento, esta busca compreender por empatia na prática ou na situação para, num segundo momento, somente após a instalação estável de uma confiança do sujeito em relação a seu "terceiroescutador", poder fazer proposições interpretativas com toda a prudência. Este é o momento de "atribuir sentido", segundo expressão de Ardoino (BARBIER, 2004, p.97).

Barbier (2004) ainda ressalta que a atitude requerida para a escuta sensível é de uma abertura holística. Trata-se de entrar numa relação de totalidade com o outro tomado em sua existência dinâmica.

Uma pessoa só existe pela existência de um corpo, de uma imaginação, de uma razão, de uma afetividade em permanente interação. A audição, o tato, o gosto, a visão, o paladar, são desenvolvidos na escuta sensível (BARBIER, 2004. p.98).

Para Szymanski (2004, p. 30), a experiência tem demonstrado que a elaboração da pergunta desencadeadora não é uma tarefa muito fácil. Há vários critérios a serem levados em conta, tais como:

a) a consideração dos objetivos de pesquisa;

b) a amplitude da questão, de forma a permitir o desvelamento de informações pertinentes ao tema que se estuda;

c) o cuidado de evitar indução de respostas;

d) a escolha dos termos da pergunta, que deverão fazer parte do universo linguístico do participante;

e) a escolha do temo interrogativo. Questões que indagam o "porquê" de alguma experiência do entrevistado receberão respostas indicadoras de causalidade, na maioria das vezes elaborações conceptuais mais do que narrativas de experiências. Se o objetivo da pesquisa for a compreensão das relações de causalidade que os participantes atribuem às suas experiências, a escolha do "porquê" é justificada. Questões que indagam o "como" de alguma experiência induzem a uma 
narrativa, a uma descrição. A partícula "para que" indaga pelo sentido que orientou uma escolha.

Szymanski (2004, p. 40) também nos lembra que, se uma entrevista é uma situação de interação humana, estamos respondendo aos estados emocionais e índices não-verbais que nosso interlocutor emite, o que não significa "adivinhar" o que o outro sente - o que é impossível - mas descrever a impressão que nos causou. Para a autora,

Além de indicar sua compreensão, a atuação do entrevistador
pode dar-se no sentido de manter o foco do problema estudado
na sua pesquisa. Sua participação pode ocorrer de diferentes
formas: elaborando sínteses, formulando questões de
esclarecimento, questões focalizadoras, questões de
aprofundamento. (SZYMANSKI, 2004, pp. 40-41).

Assim fizemos em nossa pesquisa, utilizamos os critérios supracitados na elaboração do roteiro da entrevista e, à medida que se mostrava necessário, íamos acrescentando questões no decorrer da conversa.

\subsubsection{Diálogos pedagógicos}

A discussão nos encontros do grupo de sujeitos pesquisados (momentos de Tempo Escola, principalmente) é primordial para, não somente fortalecer o sentimento de pertencimento ao grupo, como também, refletir, discutir, reavaliar e esclarecer as ações empreendidas. Os diálogos pedagógicos favorecem a defesa de pontos de vista, mas também, uma pausa em uma atividade demasiadamente agitada. Segundo Morin (2004), as opiniões diferentes ou divergentes trazem, muitas vezes, uma dimensão mais macroscópica da realidade e tornam o processo de pesquisa mais próximo da complexidade do real. Além disso, são essas discussões que suscitam as contradições existentes na comunidade, momento esse de profunda riqueza.

Ademais, a discussão é certamente uma extensão do grupo e a contribuição natural para a reflexão sobre uma ação empreendida ou a empreender.

Cada sujeito tem interesse em aprender com o outro. Morin (2004) defende que quando a pesquisa-ação visa uma mudança no discurso, a discussão, pela qual se inicia um diálogo aberto e atento, é o principal instrumento para ajudar a produzir uma reflexão esclarecedora da ação. Todos 
devem ser iguais, porque a participação de cada um é essencial para encontrar soluções adequadas ou para compreender a problemática.

A discussão é a extensão humana do grupo, sua inteligência e o lugar de reflexão e de objetivação da ação empreendida ou a empreender, seja nos diários de campo individuais, nos relatos e atas do encontro de pesquisa ou ainda, nos protocolos de observação.

\subsection{Delineamento da pesquisa}

Este processo de pesquisa iniciou-se em 2009, quando do ingresso da primeira turma da Licenciatura em Educação do Campo da UnB que teve como lócus a Faculdade UnB Planaltina - FUP. A partir da nossa adesão ao trabalho voluntário nessa Licenciatura, vislumbramos um trabalho de vanguarda em que auxiliaríamos os sujeitos em formação a ter acesso, com qualidade, a recursos que os levariam a outros patamares de inclusão social, o uso de computador e Internet e outras Tecnologias Digitais.

Aos iniciarmos a referida docência, tivemos a iniciativa de realizar 0 registro de todas as nossas ações por perceber que nossa atuação era a primeira na Universidade de Brasília, no sentido de ser uma ação afirmativa junto aos povos do campo. Em vários sentidos pudemos fazer essa análise, seja quando do ingresso desses sujeitos na Universidade, pela dinâmica das aulas em regime de bidocência ${ }^{8}$, ou por promovermos seu letramento digital, o que poderia gerar transformações significativas em suas vidas e, quiçá, em suas comunidades.

Assim, quando delineamos o processo em questão, na verdade, esta pesquisa conta com fatos ocorridos durante os 4 anos do curso.

De acordo com o planejamento do componente curricular relatado mais à frente, foram construídas ações de formação desde a apresentação do computador aos docentes em formação, até a construção de materiais digitais para sua inserção na prática docente. Assim, esta pesquisa foi composta de algumas etapas que acompanharam esse planejamento:

\footnotetext{
${ }^{8}$ Comunicação e Tecnologias da Informação é um componente curricular que acontece com a participação de dois educadores da área devido ao fato de lidar com um processo de letramento de quase 60 pessoas ao mesmo tempo em um ambiente de laboratório de informática quase totalmente desconhecido dos sujeitos em formação. No caso, fomos eu e o Prof. Márcio Ferreira.
} 
1. Início da Turma 2 (2009) - Aplicação de questionário para diagnóstico sobre a disponibilidade e acesso aos recursos de Tecnologias Digitais com ênfase em computadores e Internet.

2. Durante todo o curso (2009 - 2012) - Utilização de textos, ideias, imagens, conceitos para discutir os "conceitos permeadores" (cuja finalidade foi trabalhar uma concepção de sociedade com a centralidade no trabalho). A partir desses conceitos eram realizados os diálogos pedagógicos.

3. Durante todo o curso (2009 - 2012) - Aulas práticas sobre a utilização do computador, seus aplicativos e programas diversos em sua prática discente e também para a prática docente com observação e anotações sobre o desempenho dos docentes em formação, assim como sobre as discussões paralelas que surgiam nesse interim.

4. Aulas teóricas em que, além dos conceitos permeadores, são discutidas formas de utilização de Tecnologias Digitais no apoio ao trabalho pedagógico.

5. Aulas práticas sobre a produção e publicação de materiais didáticos digitais, também chamados de Objetos de Aprendizagem e que, nesta pesquisa são classificados como Recursos Educacionais Abertos, dadas suas características de produção, compartilhamento e possibilidade de edição por outrem.

6. Reflexões e discussões sobre as práticas realizadas tanto no aprendizado instrumental do computador e da Internet, como sobre as práticas de produção, autoria e compartilhamento feitas no Tempo Comunidade com seus pares e relatadas no retorno ao Tempo Escola.

7. Práticas de utilização do Ambiente Virtual de Aprendizagem Moodle, seja para aprender a utilizá-lo como discente, como também para sua utilização em complementariedade à prática docente.

8. Aplicação de entrevista estruturada por meio de questionário digital online para conhecer a realidade desses docentes 
depois de formados e a aplicação dos conhecimentos construídos em CTI nas escolas em que trabalham atualmente.

Todos esses momentos e atividades descritos acima foram registrados por meio de audiovisual (fotografias), anotações de campo, sínteses produzidas individualmente e posterior síntese coletiva. Faz parte da credibilidade da pesquisa-ação que a escrita seja coletiva. Os escritos são submetidos à leitura e à discussão de todos. Isso não que dizer que todos os textos devam ser escritos coletivamente, conforme defende Barbier (2004).

Também como registro de todo o trabalho realizado, os docentes em formação criaram, durante as aulas de CTI, blogs em que disponibilizam seus materiais e registram suas atividades desenvolvidas junto à comunidade e à escola em que trabalham.

\subsection{Análises e discussões}

Fizemos a opção por transferir para o capítulo em que realizamos as análises e discussões sobre as informações coletadas na pesquisa as explicações sobre como essas análises ocorreram. Nada melhor para que o leitor compreenda um processo que visualizá-lo junto ao próprio processo. Essa opção foi também didática para que a leitura não fique repetitiva ao leitor e acabe por gerar desinteresse pela leitura do restante da pesquisa.

No entanto, algumas informações iniciais são necessárias para que o leitor possa ir pensando o percurso da pesquisa com as "regras do jogo" sobre a mesa, de modo que nenhum movimento lhe passe despercebido.

Um primeiro ponto que precisamos fazer é lembrar que essa é uma pesquisa-ação, e como tal, passa por movimentos de idas e vindas constantes, o que pode parecer insucesso da investigação, mas que, na verdade, faz parte do processo de ação-reflexão-ação.

Outro aspecto essencial, para o qual trazemos Frigotto (2010) para nos auxiliar, é que esta é uma investigação que se propõe cunhada no Materialismo Histórico Dialético, que por sua vez afirma que

No processo dialético de conhecimento da realidade, o que importa fundamentalmente não é a crítica pela crítica, o conhecimento pelo conhecimento, mas a crítica e o conhecimento crítico para uma prática que altere e transforme 
a realidade anterior no plano do conhecimento e no plano histórico-social (FRIGOTTO, 2010, p.89).

Para analisar as informações construídas e registradas durante esse processo de pesquisa e formação, utilizamos o critério da verdade que para o materialismo dialético nada mais é que a prática social, ou seja, a prática é o critério decisivo para reconhecer se um conhecimento é verdadeiro ou não, se tem validade ou não. A prática social está na base de todo conhecimento e no propósito final do mesmo (TRIVIÑOS, 2008, p. 27).

Como explicitamos mais à frente, para analisar a entrevista, trabalhamos com análise de conteúdo, que, como diz Bardin,

é um conjunto de técnicas de análise das comunicações, visando, por procedimentos sistemáticos e objetivos de descrição do conteúdo das mensagens, obter indicadores quantitativos ou não, que permitam a inferência de conhecimentos relativos às condições de produção/recepção (variáveis inferidas) das mensagens (BARDIN, 1977 apud TRIVIÑOS, 2008, p. 160).

Também Minayo (1996)

aponta para três grandes tendências que orientam a análise de dados qualitativos: a análise de conteúdo, a análise de discurso e a hermenêutica dialética. Na perspectiva de Bardin, a análise de discurso não é proposta diferente da análise de conteúdo. Rey (1999), por sua vez, sugere a análise de conteúdo, com uma conotação construtivo-interpretativa, como opção para análise de discurso e análise de narrativa, proposta por Bruner (1997).(MYNAYO, 1996 apud SZYMANSKI, ALMEIDA \& PRANDINI, 2004, p. 64).

Em todo o processo de pesquisa e nos demais procedimentos de coleta de materiais, utilizamos uma análise interpretativa que se apoia em três aspectos fundamentais: a) nos resultados alcançados no estudo (respostas aos instrumentos, ideias dos documentos etc.); b) na fundamentação teórica (manejo dos conceitos-chaves das teorias e de outros pontos de vista); c) na experiência pessoal da investigadora (TRIVIÑOS, 2008, p. 173). Então, o relatório do estudo realizado é um corpo integrado desses três aspectos básicos.

Nossas categorias foram escolhidas, parte a priori, parte a posteriori. As categorias eleitas a priori foram aquelas que desde o início da elaboração do projeto de pesquisa já se apresentavam como tal por fazerem parte, seja do 
referencial teórico, seja do percurso metodológico. Assim, a priori estavam escolhidas as seguintes categorias de análise: Educação do Campo; Escola do Campo; Tecnologias Digitais e educadores do campo; contradições; utilização de Recursos Educacionais; formação docente para uso de Tecnologias Digitais. As demais categorias que aparecem nas análises e resultados, mesmo algumas não figurando como títulos, foram surgindo no decorrer do trabalho e utilizadas nas análises.

Para dar conta dessas categorias e também dos objetivos propostos é que traçamos o referencial teórico que se segue. 


\section{CAPÍTULO 2 - REFERENCIAL TEÓRICO}

Discutir todas estas questões e construir bases teóricas que respondam e subsidiem esta proposta de pesquisa nos levou a trazer estudiosos que têm escrito sobre temas de extrema relevância para a investigação que realizamos. Deste modo, a ideia foi promover diálogos entre os autores de modo a mostrar a importância de construirmos alternativas de formação de educadores do campo subsidiadas por práticas pedagógicas inovadoras, que têm como base uma educação voltada para a realidade do campo que é pautada na perspectiva de valorização da identidade da escola do campo, de transformação social e de uma educação emancipatória.

\subsection{Educação do Campo}

A chamada educação rural apresenta-se como representante de um paradigma de reprodução em que se copiava a educação feita na área urbana e, simplesmente, para reproduzi-la nas escolas rurais. Desde o ano de 1998, passou-se a utilizar a denominação Educação do Campo para retratar escolas que, apesar de estarem localizadas na área rural, desenvolvem uma educação pensada no, para e do campo, ou seja, que está naquele lugar, é pensada para aquelas pessoas e produzida a partir delas próprias, sua cultura, conhecimentos tradicionais, etc.

São fatores importantes que retratam a exclusão e a reprodução a que foram submetidas, historicamente, as comunidades do campo: falta de acessibilidade e permanência na escola; livros e materiais didáticos antigos e sem relação com a realidade do campo; distanciamento dos conteúdos escolares com os aspectos da realidade vivida pela população; fechamento de escolas e processo de nucleação; precariedade de transporte escolar e das estradas; realidade de migração dos trabalhadores rurais por diversos fatores; professores sem formação específica e sem conhecimento da realidade em que trabalha.

O que muda a partir da década de 1990? Os movimentos sociais e trabalhadores rurais organizados denominam a Educação do Campo como a que retrata a educação que se quer para os povos do campo; Aproximam-se os trabalhadores das instâncias governamentais, por meio de suas organizações. Desenvolvem-se programas educacionais voltados à formação inicial e continuada 
dos professores das escolas do campo. Investigam-se práticas e políticas educacionais no âmbito da academia, ao mesmo tempo em que a universidade aproxima-se dos povos do campo por meio de projetos de ensino, extensão e de pesquisa. Elaboram-se materiais pedagógicos que retratam a luta pela Educação do Campo e sugerem conteúdos a serem enfatizados nos processos educativos formais. Ampliam-se os canais de participação dos trabalhadores e também o aparato legislativo, numa realidade de contínuos enfrentamentos quando se está em pauta a luta pela terra e pelo direito à educação. Reiteram-se as polêmicas e os enfrentamentos políticos quanto à oferta de educação aos povos do campo e à justiça social (LEITE, 2003; GRITTI, 2003, apud SOUZA, 2010, p.445).

A caminhada educacional revela a força viva dos trabalhadores, que organizados demonstram ter condições para decidir, propor e fazer a diferença na escola do campo. Mudam concepção e prática educacional, demonstrando que a prática social é provocadora de rupturas. Inúmeros exemplos estão em vigência no país, a saber: Especialização em Educação do Campo; Escola Latino-Americana de Agroecologia; Licenciatura em Educação do Campo; Pedagogia da Terra entre tantos outros. A prática política desses cursos é de reconhecimento dos povos do campo como sujeitos que lutam, que têm história, que criam cultura e diferentes alternativas de sobrevivência no campo, diante das mais adversas intempéries climáticas, jurídicas e políticas.

Segundo Caldart (2012, pp.257-258), o surgimento da expressão "Educação do Campo" pode ser datado. Nasceu primeiro como Educação Básica do Campo no contexto de preparação da I Conferência Nacional por uma Educação Básica do Campo, realizada em Luziânia, Goiás, de 27 a 30 de julho 1998. Passou a ser chamada Educação do Campo a partir das discussões do Seminário Nacional realizado em Brasília de 26 a 29 de novembro 2002, decisão posteriormente reafirmada nos debates da II Conferência Nacional, realizada em julho de 2004.

As discussões de preparação da I Conferência iniciaram-se em agosto de 1997, logo após o I Encontro Nacional dos Educadores e Educadoras da Reforma Agrária (ENERA), realizado pelo Movimento dos Trabalhadores Rurais Sem Terra (MST), em julho daquele ano, evento em que algumas entidades desafiaram o MST a levantar uma discussão mais ampla sobre a educação no meio rural brasileiro. 
No mesmo bojo de desafios, surgiu o Programa Nacional de Educação na Reforma Agrária (PRONERA), criado pelo governo federal em 16 de abril de 1998 e que ainda hoje está em vigência, mesmo que sob fortes tensões (CALDART, 2012, pp.258).

Nas discussões de preparação do documento base da I Conferência, concluído em maio de 1998 e debatido nos encontros estaduais que antecederam o evento nacional, estão os argumentos do batismo do que representaria um contraponto de forma e conteúdo ao que no Brasil se denomina Educação Rural:

Utilizar-se-á a expressão campo, e não a mais usual, meio rural, com o objetivo de incluir no processo da conferência uma reflexão sobre o sentido atual do trabalho camponês e das lutas sociais e culturais dos grupos que hoje tentam garantir a sobrevivência desse trabalho. Mas, quando se discutir a educação do campo, se estará tratando da educação que se volta ao conjunto dos trabalhadores e das trabalhadoras do campo, sejam os camponeses, incluindo os quilombolas, sejam as nações indígenas, sejam os diversos tipos de assalariados vinculados à vida e ao trabalho no meio rural. Embora com essa preocupação mais ampla, há uma preocupação especial com o resgate do conceito de camponês. Um conceito histórico e político... (KOLLING, NERY e MOLINA, 1999, p. 26 apud CALDART, 2012, p.258).

O argumento para mudar o termo Educação Básica do Campo para Educação do Campo aparece nos debates de 2002, realizados no contexto da aprovação do parecer do Conselho Nacional de Educação (CNE) ㄲo 36/2001, relativo às Diretrizes Operacionais para a Educação Básica nas Escolas do Campo (Brasil, 2001) e com a marca de ampliação dos movimentos camponeses e sindicais envolvidos nessa luta:

Temos uma preocupação prioritária com a escolarização da população do campo. Mas, para nós, a educação compreende todos os processos sociais de formação das pessoas como sujeitos de seu próprio destino. Nesse sentido, educação tem relação com cultura, com valores, com jeito de produzir, com formação para o trabalho e para a participação social. (KOLLING, CERIOLI e CALDART, 2002, p. 19 apud CALDART, 2012, p.258).

E, no plano da luta por escolas, afirmou-se ali que o direito à educação compreende da educação infantil à universidade (ibid., p. 34). 
O esforço feito no momento de constituição da Educação do Campo, e que se estende até hoje, foi de partir das lutas pela transformação da realidade educacional específica das áreas de Reforma Agrária, protagonizadas naquele período especialmente pelo MST, para lutas mais amplas pela educação do conjunto dos trabalhadores do campo. Para isso, era preciso articular experiências históricas de luta e resistência, como as das escolas família agrícola, do Movimento de Educação de Base (MEB), das organizações indígenas e quilombolas, do Movimento dos Atingidos por Barragens (MAB), de organizações sindicais, de diferentes comunidades e escolas rurais, fortalecendo-se a compreensão de que a questão da educação não se resolve por si mesma e nem apenas no âmbito local: não é por acaso que são os mesmos trabalhadores que estão lutando por terra, trabalho e território os que organizam esta luta por educação. Também não é por acaso que se entra no debate sobre política pública (CALDART, 2012, pp.259).

Importantes eventos e documentos foram construídos/elaborados e reconhecidos, a partir das lutas dos Movimentos Sociais do Campo, para que a Educação do Campo se fizesse presente nas Políticas Públicas:

$\checkmark$ I Conferência Por uma Educação do Campo - 1998;

$\checkmark$ I Seminário Nacional de Educação do Campo - 2002;

$\checkmark$ II Conferência Por uma Educação Básica do Campo - 2004;

$\checkmark$ Diretrizes Operacionais para Educação Básica das Escolas do Campo - após audiências públicas e amplas discussões promovidas entre a Câmara de Educação Básica do Conselho Nacional de Educação, representantes de órgãos normativos estaduais e municipais, movimentos sociais e sindicais, universidades ONGs e demais setores da sociedade que atuam no campo brasileiro, em 12/03/2001 foram homologadas pelo Ministro da Educação Diretrizes Operacionais para Educação Básica das Escolas do Campo, por meio da Resolução CNE/CEB №1, de 3 de abril de 2002. As Diretrizes Operacionais para Educação Básica das Escolas do Campo são normas e critérios políticos, pedagógicos, administrativos e financeiros que tem 
fundamentos legais e servem para orientar a organização das escolas do campo, cujas regras devem ser regulamentadas pelos sistemas de ensino municipal, estadual e federal da educação básica (Cartilha da CONTAG, p.5). Conforme consta no Art. $2^{\circ}$ do próprio documento,

Estas Diretrizes, com base na legislação educacional, constituem um conjunto de princípios e de procedimentos que visam adequar o projeto institucional das escolas do campo às Diretrizes Curriculares Nacionais para a Educação Infantil, o Ensino Fundamental e Médio, a Educação de Jovens e Adultos, a Educação Especial, a Educação Indígena, a Educação Profissional de Nível Técnico e a Formação de Professores em Nível Médio na modalidade Normal.

A Resolução № 2 Do Conselho Nacional de Educação (CNE 2008) - estabelece diretrizes complementares, normas e princípios para o desenvolvimento de políticas públicas de atendimento da Educação Básica do Campo. Esta resolução define orientações importantes sobre a organização escolar no campo, restringindo o transporte escolar para crianças muito pequenas, priorizando que o ensino fundamental seja oferecido prioritariamente nas próprias comunidades, para inibir 0 fechamento das escolas e a nucleação na cidade.

$\checkmark$ DECRETO PRESIDENCIAL 7.352, de 4 de novembro de 2010 Esse decreto dispõe sobre a política de Educação do Campo e o Programa Nacional de Educação na Reforma Agrária (PRONERA). O documento define que a oferta de educação básica e superior para as populações do campo será desenvolvida pela União, com a colaboração dos estados e municípios. O decreto determina o respeito à diversidade do campo, o incentivo à formulação de projetos político-pedagógicos específicos para o campo, desenvolvimento de políticas de formação de profissionais da educação específicas, valorização da identidade da escola do campo e controle social da qualidade da educação escolar.

PRONACAMPO - Programa Nacional de Educação do Campo lançado em 20 de março de 2012, o Programa é uma ação do 
Governo Federal resultado da mobilização dos movimentos sociais e sindicais do campo, para construção de referências de política nacional de educação do campo, com apoio do MEC. O Pronacampo oferece apoio técnico e suporte financeiro para estados e municípios implementarem suas respectivas políticas de Educação do Campo, através de um conjunto de ações articuladas, que atendem às escolas do campo e quilombolas em quatro eixos: gestão e práticas pedagógicas, formação de professores, educação de jovens e adultos e educação profissional e tecnológica e infraestrutura. O programa trabalha a educação contextualizada, ou seja, promovendo a interação entre conhecimento científico e os saberes das comunidades.

\subsection{Escolas do Campo}

Olhar para a realidade do campo brasileiro é olhar para um universo rico em cultura, história, valores, processos diversos de humanização e de trajetórias de vida e luta. A escola do campo é um micro-universo que reflete toda essa riqueza do território em que se constrói. Assim, como nos diz Caldart,

Olhar a escola como um lugar de formação humana significa dar-se conta de que todos os detalhes que compõem o seu dia a dia, estão vinculados a um projeto de ser humano, estão ajudando a humanizar ou a desumanizar as pessoas. Quando os educadores se assumem como trabalhadores do humano, formadores de sujeitos, muito mais do que apenas professores de conteúdos de alguma disciplina, compreendem a importância de discutir sobre suas opções pedagógicas e sobre que ser humano estão ajudando a produzir e a cultivar [...].

Trata-se de enxergar a educação, afinal, como uma relação entre sujeitos. A escola reconhece seus educandos e suas famílias como sujeitos. O movimento social e seus sujeitos igualmente reconhecem os educadores como sujeitos. $E$ todos se veem como sujeitos de um movimento maior que é o movimento da história, exatamente o que pressiona a cada um para que assuma esta condição de sujeito. Nesta concepção está também a ideia de que são os seres humanos, as pessoas que fazem as transformações sociais, ainda que sempre condicionadas pelo formato material das relações sociais em que se inserem, e que não determinam pessoalmente (CALDART, 2003, p.72). 
Os autores Leite (1999) e Gritti (2003) caracterizaram a trajetória da educação pública rural no Brasil. O que se observa é a marginalidade da educação rural na legislação e ao mesmo tempo a preocupação "pedagógica" com um ensino voltado à domesticação do homem do campo, como se ele não tivesse vontade própria (LEITE \& GRITTI, 2003).

Reside aí um primeiro elemento para definir concepção de Educação do Campo: quem é o sujeito da educação? A educação era pensada para os trabalhadores. Agora, intenta-se que a educação seja construída na luta social, dos próprios trabalhadores. Há que se analisar em que medida a Educação do Campo tem conseguido superar a concepção educacional voltada PARA os trabalhadores e, de fato, construído a educação COM os trabalhadores (LEITE \& GRITTI, 2003 apud SOUZA, 2010).

O modelo brasileiro de educação rural apresenta uma série de elementos os quais aparecem na legislação, nas instituições pedagógicas, no currículo e mesmo nas "recomendações" dos organismos internacionais, que possibilitam traçar um esboço da educação rural brasileira a partir dos anos 30 . Pinçarei alguns desses elementos com os quais é possível desocultar, embutido nas propostas para a educação rural, o movimento do capital de desestruturação da produção camponesa, tanto para a formação de um mercado de força de trabalho quanto para a constituição de condições para a modernização da produção agrícola. O emprego de máquinas, de tecnologias e insumos, próprios desta modalidade de produção, demandará o aumento das lavouras e, consequentemente, das propriedades rurais, fortalecendo 0 latifúndio que nasce com a colonização.

Esse referencial implantou-se, de forma definitiva um modelo de escola na área rural e urbana do nosso país, fundamentado numa concepção que, segundo Whitaker e Antuniassi (1992), tem três características fundamentais:

- é urbanocêntrica, unicamente voltada aos conteúdos formados e informados no processo de urbanização e industrialização; o ponto de partida e de chegada do conhecimento é a cidade, apresentada como superior e moderna. O mundo rural precisa ser 
abandonado por quem quer vencer na vida, uma vez que nele não há chance de se progredir;

- é sociocêntrica, voltada aos interesses de certas classes sociais, não considerando a diversidade dos sujeitos sociais existentes no campo e na cidade, a sua cultura, as suas diversas formas de organizar o trabalho e a vida;

- é etnocêntrica, privilegiadora dos conhecimentos relativos ao mundo ocidental industrializado, de uma forma de pensar e de um estilo de vida baseado na homogeneidade, onde os valores e a cultura camponesa são considerados como atrasado, conservadores, criando, assim, estereótipos com relação a população do campo e ao seu modo de viver e de pensar.

Nesse cenário, como se construía a escola pública rural? Eram as conhecidas escolinhas unidocentes, com classes multisseriadas e com conteúdos marcados pela ideologia da sociedade capitalista urbana.

Com essas características a escola foi institucionalizada no campo não considerando os seguintes aspectos: a população à qual se destinava, o contexto em que se situava, as relações sociais, produtivas e culturais e a necessidade de formação socioprofissional desse povo.

Pensando nesse contexto, três questões foram levantadas para que nosso debate se qualificasse: Qual é o papel da educação na construção de um projeto de desenvolvimento nacional que faça surgir a plena cidadania? Qual é o papel que as escolas do campo devem assumir a fim de incentivar a construção de iniciativas que reduzam os problemas agravantes existentes na sociedade brasileira? E, por fim, quais as políticas públicas, concepções e princípios pedagógicos são necessários para se construir a identidade de uma escola do campo? Silva nos afirma que esses são questionamentos em movimento que necessitam ser esclarecidos por todos e todas que se comprometam com a causa. (SILVA, S/D, pp.2-3).

Para Leite e Gritti (2003), os conceitos que auxiliam na compreensão da realidade educacional e da escola pública, particularmente no campo brasileiro, são exclusão/inclusão, luta social e direito. 
Para mudar essa realidade, a partir da luta dos movimentos sociais do campo, surge a escola do campo. No bojo do movimento da Educação do Campo, a partir das experiências de formação humana desenvolvidas no contexto de luta dos movimentos sociais camponeses por terra e educação nasce e se desenvolve a concepção de escola do campo. Trata-se de uma concepção que emerge das contradições da luta social e das práticas de educação dos trabalhadores do e no campo (MOLINA \& SÁ, 2012, p.326). A escola do campo, a partir da concepção sobre a qual nos falam Molina e Sá, além de não se encaixar nas concepções de escola hegemônicas e no projeto de educação proposto para a classe trabalhadora modo de produção capitalista, elas ainda são antagônicas a ele.

Quando pensamos em discutir as questões concernentes às escolas do campo brasileiro, torna-se necessário tratarmos das questões levantadas por Caldart (2004, p.90) e que têm sua importância para esta discussão por ainda fazerem parte das discussões acerca do currículo e das práticas pedagógicas das escolas do campo:

Que escola está sendo produzida pelo movimento social do campo em nosso país? Qual o lugar da escola na dinâmica de organizações e movimentos que participam da luta por um novo projeto de desenvolvimento do campo? (CALDART, 2004, p.90).

Ainda, nos cabe perguntar: Qual é a realidade das escolas do campo brasileiras hoje? Como trabalham? Com quais profissionais? Com que recursos? Que salários? Qual a formação desses profissionais? Quais os materiais didáticos disponíveis? Qual distribuição dos estudantes? Que currículo é adotado? Quais os critérios de avaliação? Que tipo de avaliação é adotada? Como é a organização do processo educativo dessas escolas? Que escola e que currículo temos visto no campo brasileiro desde os primórdios da educação brasileira? Com que importância as escolas do campo têm sido tratadas pelos governos ao longo de sua história? Que práticas pedagógicas são desenvolvidas no seio dessas escolas? Estas e tantas outras questões, neste momento, servirão de estímulo para buscarmos conhecer um pouco mais sobre essa realidade há tanto escamoteada, não cabendo, agora, ampliar esta discussão, mas apenas trazê-la ao debate, fazê-la emergir. 
Silva nos lembra que

O modelo de desenvolvimento implementado no campo brasileiro foi tão excludente que marca até hoje o modelo de educação adotado no Brasil. A escola brasileira, de 1500 até o início do século $\mathrm{XX}$, serviu e serve para atender as elites, sendo inacessível para grande parte da população rural. Para as elites do Brasil agrário, as mulheres, indígenas, negros e trabalhadores rurais não precisavam aprender a ler e escrever, visto que nessa concepção para desenvolver o trabalho agrícola não precisava de letramento (SILVA, S/D, p.1).

Caldart (2003, p.72) ressalta o quanto a escola é, de modo geral, uma instituição conservadora e resistente à ideia de movimento e a um vínculo direto com as lutas sociais. O serviço que historicamente a escola tem prestado à manutenção de relações sociais de dominação e exclusão costuma estar encoberto por uma aparência de autonomia e de neutralidade política. Conforme Caldart (2003), quando defendemos um vínculo explícito da escola com processos pedagógicos de formação de sujeitos que têm propósitos de transformação social, faz-se necessário ter clareza de que sozinha a escola não provocará isto. Ao contrário, é o movimento social que precisa ocupar e ocupar-se da escola, construindo junto com os educadores que ali estão, o seu novo projeto educativo. Arroyo traz uma fala que complementa quando diz que

\begin{abstract}
Não podemos cair no erro de pensar que porque o campo está vivendo uma contradição, que está em tensão e novos sujeitos políticos estão se constituindo no campo e desse modo, a escola, por conta disso, vai ser outra. A escola é uma instituição com estruturas, culturas e valores consolidados e como todas as instituições, ela é mais lenta que os sujeitos dos movimentos. Logicamente, existem pesquisas sobre isto que precisam ser contextualizadas e aprofundadas. Mas os movimentos sociais do campo trazem uma ideia que faz com a escola do campo possa desenvolver a partir do ritmo das lutas e das valorizações identitárias que a Educação do Campo busca: a escola como direito, ou melhor, a educação do campo no campo dos direitos (ARROYO, 2004a, p.97).
\end{abstract}

Caldart, então, sintetiza bem a ideia da escola do campo quando diz que:

Uma escola do campo não é, afinal, um tipo diferente de escola, mas sim é a escola reconhecendo e ajudando a fortalecer os povos do campo como sujeitos sociais, que também podem ajudar no processo de humanização do conjunto da sociedade, com suas lutas, sua história, seu trabalho, seus saberes, sua cultura, seu jeito. Também pelos 
desafios da sua relação com o conjunto da sociedade. Se é assim, ajudar a construir escolas do campo é, fundamentalmente, ajudar a constituir os povos do campo como sujeitos, organizados e em movimento. Porque não há escolas do campo sem a formação dos sujeitos sociais do campo, que assumem e lutam por esta identidade e por um projeto de futuro (CALDART, 2003, p. 66).

Paulo Freire, em sua Pedagogia do Oprimido disse: “... a escola não transforma a realidade, mas pode ajudar a formar os sujeitos capazes de fazer a transformação, da sociedade, do mundo, de si mesmo..." (FREIRE, 1997, p. 72). Essa transformação é almejada e articulada por um movimento histórico de construção da concepção de escola do campo, pelas forças sociais da classe trabalhadora mobilizadas no momento atual na disputa contra hegemônica, faz parte do mesmo movimento de construção de um projeto de campo e de sociedade (MOLINA \& SÁ, 2012, pp.326-327).

De acordo com Freitas,

se a ligação da escola é com a vida, entendida como atividade humana criativa, é claro que a vida no campo não é a mesma vida da cidade. Os sujeitos do campo são diferentes dos sujeitos da cidade [...] O campo tem sua singularidade, sua vida, e a educação do campo, portanto, não pode ser a mesma da educação urbana, ainda que os conteúdos escolas venham a ser os mesmos. A questão aqui não é reconhecer que há uma identidade para os sujeitos do campo, mas reconhecer que há toda uma forma diferente de viver, a qual produz relações sociais, culturais e econômicas diferenciadas. Se tomamos o trabalho, ou seja, a vida como princípio educativo, então, necessariamente os processos educativos no campo serão também diferenciados no sentido de que o conteúdo da vida $^{9}$ ao qual se ligará o conteúdo escolar é outro (FREITAS, 2010 apud MOLINA, 2014, p. 269-270).

Para Caldart (2003, p. 68), a concepção de escola do campo brota nesse processo de luta e tentativa de superação do modo de produção capitalista pela classe trabalhadora. Luta esta que, além do direito à terra, de permanecer nesse território de origem e à identidade de classe dos sujeitos coletivos do campo, também reivindica o acesso ao conhecimento e a garantia do direito à escolarização, assim como ter uma escola que possa atender, compreender e transformar as realidades concretas e históricas do campo, considerando o campo em toda sua complexidade, valorizando os conhecimentos e culturas de seus sujeitos, garantindo o protagonismo das

\footnotetext{
${ }^{9}$ Grifo do autor.
} 
pessoas na construção de sua própria história e também daquilo que faz parte do currículo da escola de seus filhos e filhas.

A concepção de escola do campo se insere também na perspectiva gramsciana da Escola Unitária, no sentido de desenvolver estratégias epistemológicas e pedagógicas que materializem o projeto marxiano da formação humanista omnilateral, com sua base unitária integradora entre trabalho, ciência e cultura, tendo em vista a formação dos intelectuais da classe trabalhadora (MOLINA \& SÁ, 2012, p.327).

Para as autoras (MOLINA \& SÁ, 2012), um projeto de formação de sujeitos que percebam criticamente as escolhas e premissas socialmente aceitas e que sejam capazes de formular alternativas de um projeto político, atribui à escola do campo uma importante contribuição no processo mais amplo de transformação social. A essa escola é colocado o desafio de formular e executar um projeto de educação integrado a um projeto político de transformação social liderado pela classe trabalhadora, ou seja, de conceber e desenvolver uma formação contra-hegemônica, o que só é possível a partir de uma formação integral dos trabalhadores do campo em que se promova, simultaneamente, a transformação do mundo e a autotransformação humana. (MOLINA \& SÁ, 2012, p.327).

Ainda de acordo com Molina e Sá (2012), para a materialização desta condição a formação da capacidade dirigente da classe trabalhadora é questão central, pois só a partir dessa formação se poderá exercer o controle do processo de reprodução social no interesse das necessidades sociais básicas, tirando do controle os grupos historicamente constituídos e que reproduzem práticas opressoras e excludentes.

Assim, esse processo formativo estaria, conforme Gramsci, intrinsecamente vinculado à atividade crítica e organizativa dos intelectuais orgânicos no conjunto de atividades culturais e ideológicas da luta de classes, na disputa entre os projetos de sociedade. Segundo Gramsci (1991), a capacidade intelectual não é monopólio de alguns, pertencendo, assim, a toda a coletividade, seja no sentido do acúmulo de conhecimento ao longo da história da humanidade ou no sentido da elaboração de novos conhecimentos que permitam compreender e superar as contradições do momento presente. Para ele, o exercício da intelectualidade é função de um "intelectual coletivo" e, 
embora alguns indivíduos desempenhem funções mais estritamente intelectuais na sociedade, o grau dessa atividade entre seus componentes é apenas quantitativo (MOLINA \& SÁ, 2012, p.327).

A forma pela qual esta escola se conecta ao mundo do trabalho e às organizações políticas e culturais dos trabalhadores do campo determinará ou não a possibilidade do exercício deste papel fundamental da escola do campo na formação desse intelectual coletivo. Pode-se, então, dizer que

a escolarização em todos os níveis deve promover o conhecimento sobre o funcionamento da sociedade, sobre os mecanismos de dominação e subordinação que a caracterizam e sobre o modo de integração da produção agrícola neste projeto de sociedade, a partir do complexo sistema de relações e de mediações que constitui o processo de desenvolvimento rural (MOLINA \& SÁ, 2012, pp.326-327).

Daí a necessidade que a escola do campo, pensada como parte de um projeto maior de educação da classe trabalhadora, construa práticas educativas que, efetivamente, fortaleçam os camponeses para as lutas principais, no bojo da constituição histórica dos movimentos de resistência à expansão capitalista em seus territórios. Práticas essas que precisam privilegiar os saberes e culturas locais e também os conhecimentos historicamente construídos necessários à sua atuação nos processos de gestão desta nova escola.

Os vários anos do MST já nos permitem dizer que a luta social dos Sem Terra pode ser compreendida também como um processo pedagógico de enraizamento humano. Lutadores do povo se formam nas lutas sociais que têm raiz e projeto, e que enraízam as pessoas, devolvendo-lhes perspectivas de futuro.

Segundo Simone Weil, o enraizamento é uma das necessidades do ser humano. E ter raiz, nos diz ela, é participar real e ativamente de uma coletividade que conserva vivos certos tesouros do passado e certos pressentimentos do futuro (WEIL, 1943 apud CALDART, 2003, p.70). Enraizado é o sujeito que tem laços que permitem olhar tanto para trás como para frente. Ter projeto, por sua vez é ir transformando estes pressentimentos de futuro em um horizonte pelo qual se trabalha, se luta. Não há, pois, como ter projeto sem ter raízes, porque são as raízes que nos permitem enxergar o 
horizonte. Assim, as raízes nos mostram o horizonte em que se projeta algo, em que se vislumbra algo melhor.

De acordo com Caldart (2003), o enraizamento projetivo é, pois, um dos processos fundamentais de formação dos lutadores do povo, assim como talvez o seja de qualquer ser humano. A escola não é capaz de enraizar as pessoas porque não têm em si mesmas a força pedagógica material necessária para isso. Mas a escola, dependendo das opções pedagógicas que faça, pode ajudar a enraizar ou a desenraizar; pode ajudar a cultivar utopias ou um presenteísmo de morte.

Toda vez que uma escola desconhece e ou desrespeita a história de seus alunos, toda vez que se desvincula da realidade dos que deveriam ser seus sujeitos, não os reconhecendo como tal, ela escolhe ajudar a desenraizar e a fixar seus educandos num presente sem laços (CALDART, 2003, p.70).

E caso isso aconteça a um grupo social desenraizado ou com raízes muito frágeis, estas pessoas estarão perdendo mais uma de suas chances de serem despertadas para a própria necessidade de voltar a ter raiz, a ter projeto. Do ponto de vista do ser humano isto é muito grave, é violentamente desumanizador.

Para transformarmos a escola do campo são necessárias mudanças significativas tanto no currículo quanto nas práticas pedagógicas por ela adotada, conforme arrazoa Molina,

Inspirada na experiência de Pistrak (2000), a proposta curricular da Escola do Campo deve necessariamente se vincular aos processos sociais vividos no intuito de transformação social, articulando-se criticamente aos modos de produção de conhecimento e da vida presentes na experiência social. Muito embora a Escola do Campo mantenha os traços universais que toda educação deve apresentar, essa é uma condição fundamental para que ela possa contribuir, com base nas especificidades da vida rural, para a superação da alienação dos sistemas educativos em relação às transformações sociais (MOLINA, 2014, p. 269).

Algumas práticas de educação no MST apontam pelo menos três tarefas importantes que, segundo Caldart (2003, pp.70-71), a escola pode assumir na perspectiva de cultivar e fortalecer os processos de enraizamento humano: 
$\checkmark$ Memória: a escola é um lugar muito próprio para recuperar e trabalhar com os tesouros do passado. Celebrar, construir e transmitir, especialmente às novas gerações, a memória coletiva, ao mesmo tempo em que buscar conhecer mais profundamente a história da humanidade. É o que chamamos no MST de pedagogia da história.

$\checkmark$ Mística: ela é a alma dos lutadores do povo; o sentimento materializado em símbolos que ajudam as pessoas a manter a utopia coletiva. No MST a mística é uma das dimensões básicas do processo educativo dos Sem Terra. A escola pode ajudar a cultivar a mística, os símbolos e o sentimento de fazer parte desta luta. Não fará isso se não conseguir compreender o desafio pedagógico que tem, diante da afirmação de uma criança de acampamento ou assentamento que diz: sou Sem Terrinha, sou filha da luta pela terra e do MST!

$\checkmark$ Valores: raiz e projeto se constituem de valores; e são os valores que movem uma coletividade; a escola pode criar um ambiente educativo que recupere, forme, fortaleça os valores humanos, aqueles que permitem cada pessoa crescer em dignidade, humanidade. E que problematize, combata e destrua os valores anti-humanos, que degradam o ser humano e impedem a constituição de coletividades verdadeiras e fortes. Mas a escola não fará isto apenas com palavras, e sim com ações, com vivências, com relações humanas, temperadas por um processo permanente de reflexão sobre a prática do coletivo, de cada pessoa.

Esse processo de enraizamento que compete à escola, pode ser fortalecido por meio das Tecnologias Digitais, facilitando o registro dessa dinâmica própria do campo? É possível, aos educadores e educandos, utilizarse dessas tecnologias para filmar, fotografar e registrar de modos diversos as místicas, as manifestações culturais e religiosas, as reuniões políticas? Para além do registro, esse material pode servir de material didático-pedagógico para as aulas, possibilitando novas práticas pedagógicas a partir dos saberes 
locais? São estas questões que queremos verificar a partir do acesso dos educadores do campo em formação na LEDOC.

\subsection{Formação de Educadores do Campo: a Licenciatura em Educação do Campo na UnB (LEdoC - UnB)}

Arroyo inicia o texto sobre formação de educadores do campo no Dicionário de Educação do Campo, "a concepção e a política de formação de professores do campo vão se construindo na conformação da educação do campo" (ARROYO, 2012, p.359).

A luta pela garantia do direito à educação escolar para os
camponeses passa pela criação de escolas no campo; pelo
não fechamento das existentes; pela ampliação da oferta dos
níveis de escolarização nas escolas que estão em
funcionamento; e principalmente, pela implantação de uma
política pública de formação de educadores do campo. Durante
esta última década, nos encontros locais, regionais e nacionais
de Educação do Campo, sempre constou como prioridade
dos movimentos sociais a criação de uma política pública de
apoio à formação de educadores. (MOLINA, MOURÃO,
FERREIRA e CASTRO, 2010, p. 01).

Os movimentos sociais inauguram e afirmam um capítulo na história da formação pedagógica e docente. Na diversidade de suas lutas por uma educação do/no campo, que fazem parte de um outro projeto de campo, priorizam programas, projetos e cursos específicos de Pedagogia da Terra, de formação de professores do campo, de professores indígenas e quilombolas. Para trazer à tona essa discussão, Arroyo (2012, p.359) nos coloca algumas questões norteadoras: Como está sendo construída essa concepção de formação? Quem são os sujeitos dessa política? Como ela contribui na consolidação da educação do campo? Que contribuições traz para as políticas e os currículos da formação docente e pedagógica?

Os movimentos do campo e o Programa Nacional de Educação na Reforma Agrária (PRONERA) tentam quebrar essa visão genérica de docenteeducador e, dessa maneira, superar as desastrosas consequências para a afirmação da educação do campo. Segundo Arroyo, esses movimentos se afirmam não como reivindicadores de mais escolas e de mais profissionais, mas como sujeitos coletivos de políticas de formação de docentes-educadores. Deles e de suas lutas por terra, território, agricultura camponesa e Reforma 
Agrária parte a defesa de cursos de Pedagogia da Terra e de formação de professores do campo (ARROYO, 2012, p.360).

A política de formação de professores do campo de que os movimentos sociais são autores está sendo um processo que obriga a repensar e redefinir a relação entre o Estado, as suas instituições e os movimentos sociais. Esse processo tem um significado de grande relevância política. Consequentemente, os currículos de formação têm como um dos seus objetivos formar profissionais do campo capazes de influir nas definições e na implantação de políticas educacionais, ou seja, os currículos objetivam afirmar esses profissionais como sujeitos de políticas (ARROYO, 2012, p.360).

$\mathrm{Na}$ medida em que os(as) militantes-educadores(as) dos movimentos que chegam a esses cursos carregam radicalidades políticas, culturais e educativas, acumuladas nas lutas dos movimentos, eles passam a exigir dos cursos de formação o reconhecimento desses saberes, valores, concepções de mundo, de educação, como ponto de partida de sua formação (ARROYO, 2012, p.361).

Demanda-se dos currículos que incorporem, sistematizem e aprofundem esses saberes e essa formação acumulada, e que os ponham em diálogo com seu direito aos saberes e concepções das teorias pedagógicas e didáticas, de organização escolar, de ensino-aprendizagem para a garantia do direito à educação dos povos do campo. Nessas tensões, vai se conformando a concepção de formação de professores e professoras do campo. Essa é uma das contribuições da concepção de formação dos profissionais do campo para a formação de todo profissional de educação básica: reconhecer os saberes do trabalho, da terra, das experiências e das ações coletivas sociais e legitimar esses saberes como componentes teóricos dos currículos (ARROYO, 2012, p.361).

O reconhecimento e incorporação dessa riqueza de aprendizados que entram nos cursos de Pedagogia da Terra, de formação de professores do campo e de professores indígenas e quilombolas exige mudar as identidades dos cursos de formação como meros capacitadores para o exercício do magistério e reconhecê-los como o lugar aberto aos saberes, valores e práticas educativas que se dão na dinâmica social, política e cultural, nos movimentos 
sociais que chegam aos cursos às universidades. A trajetória de conformação da política de formação de professores do campo mostra não ser nada fácil fazer essas mudanças. Os cursos e seus educandos são mantidos à margem do funcionamento das faculdades e universidades, reproduzindo o trato histórico marginalizado desses coletivos (ARROYO, 2012).

Quais as possibilidades e os limites que mudanças nas formas de conhecer e acessar informações e conhecimentos de outras comunidades podem trazer para as práticas de resistência e permanência dos sujeitos coletivos do campo, nas lutas para permanecerem como tais? Em que medida novas estratégias e princípios de formação docente para as escolas do campo podem contribuir para fazer delas espaços de promoção e apoio ao desenvolvimento dos sujeitos camponeses e de seus territórios?

De acordo com Molina (2014),

Como parte integrante das relações de poder na sociedade, a universidade pública é um aparelho tradicional de hegemonia no interior do qual se apresenta uma diversidade de projetos em disputa pela direção intelectual e moral da sociedade. Sua autonomia relativa faz com que esse espaço se configure como um contraditório especialmente relevante para uma reflexão sobre a materialidade práxica dos projetos de sociedade que nela se forjam e se expandem para o conjunto da sociedade civil (MOLINA, 2014, p. 273).

Assim, uma das experiências piloto de formação de educadores nas universidades federais é a Licenciatura em Educação do Campo da Universidade de Brasília - LEdoC-UnB. Os princípios que regem as práticas formativas desenvolvidas na LEdoC, trazem como pano de fundo questões sobre as especificidades do perfil de Educador do Campo que esta graduação intenciona formar, em conjunto com os movimentos sociais participantes neste processo histórico. Estas práticas formativas desenvolvidas em parceria com os movimentos sociais e sindicais do campo têm caminhado no sentido da formação dos educadores que atuem para muito além da educação escolar. Esta é considerada uma das dimensões do processo educativo. Mas, pela própria compreensão acumulada na Educação do Campo, da centralidade dos diferentes tempos e espaços formativos existentes na vida do campo, nas lutas dos sujeitos que aí vivem e que se organizam para continuar garantindo sua reprodução social neste território, a ação formativa desenvolvida por estes 
educadores deverá ser capaz de compreender e agir em diferentes espaços, tempos e situações. Esta compreensão, portanto, articula a formação e a preparação para gestão dos processos educativos escolares e também para gestão dos processos educativos comunitários: pretende-se formar educadores capazes de promover profunda articulação entre escola e comunidade.

Este perfil de educador do campo que os movimentos demandam exige uma compreensão ampliada de seu papel. Tem a compreensão da educação como prática social; da necessária inter-relação do conhecimento; da escolarização; do desenvolvimento; da construção de novas possibilidades de vida e permanência nestes territórios pelas lutas coletivas dos sujeitos do campo. Possibilidades estas cujas estratégias de construção devem contar com a atuação destes educadores do campo, comprometidos com suas comunidades.

Compreende-se como tarefa desses processos educativos a formação das habilidades necessárias para que as crianças e jovens do campo tornemse, não só críticos consumidores de conhecimentos e tecnologias produzidos por outrem, mas, principalmente, tornem-se produtores de novos conhecimentos, articulando os saberes científicos aos conhecimentos adquiridos e produzidos a partir de sua própria vivência sócio-histórica como sujeito camponês.

Esta Licenciatura habilita educadores para atuarem nos anos finais do Ensino Fundamental e também no Ensino Médio, através de nova estratégia de formação docente, cuja principal característica é formação multidisciplinar, capacitando estes futuros educadores para o desenvolvimento de práticas docentes em grandes áreas de conhecimento. Estes cursos têm como perspectiva a preparação de educadores para uma atuação profissional que vai além da docência, incluindo também a formação para a gestão dos processos educativos que acontecem na escola e no seu entorno, bem como para produção de materiais específicos para o trabalho em escolas do campo (UnBFUP, 2009a).

Os objetivos gerais da LEdoC-UnB são: 
$\checkmark$ formar educadores para atuar com sujeitos que trabalham e vivem no e do campo, de modo a atender às diferentes etapas da Educação Básica, buscando concretizar a Educação do Campo como direito humano e como instrumento de desenvolvimento social;

$\checkmark$ produzir estratégias educativas para um trabalho docente multidisciplinar onde a organização curricular se dê por áreas do conhecimento nas escolas do campo;

$\checkmark$ contribuir para o avanço da Educação Básica no e do campo por meio da elaboração de formas alternativas de organização do trabalho escolar, buscando reduzir as desigualdades de direito ao acesso à educação de qualidade pelos povos do campo;

$\checkmark$ articular-se com outras instituições de educação superior e demais parceiros no sentido de ampliar iniciativas de ensino, de pesquisa e de extensão que atendam às necessidades do homem do campo (FERREIRA, 2014, p.55).

Uma das principais características diferenciadoras em relação a outras licenciaturas é que a metodologia, por ter como foco grupos sociais do campo, utiliza-se da Pedagogia da Alternância ${ }^{10}$, tendo diferentes tempos e espaços formativos em sua execução. Existem os períodos de formação que acontecem na universidade proponente, denominados Tempo Escola, e existem os períodos de formação nas comunidades rurais das quais se originam estes sujeitos, chamados de Tempo Comunidade, nos quais são desenvolvidas práticas educativas em diferentes áreas de conhecimento, com a presença e o acompanhamento dos docentes da universidade que é responsável por sua oferta. A intencionalidade pedagógica desta metodologia é oportunizar durante a própria formação destes estudantes a possibilidade de sua prática como

\footnotetext{
${ }^{10}$ A Pedagogia da Alternância atribui grande importância à articulação entre momentos de atividade no meio socioprofissional do jovem e momentos de atividade escolar propriamente dita, nos quais se focaliza o conhecimento acumulado, considerando sempre as experiências concretas dos educandos (TEIXEIRA, BERNARTT \& TRINDADE, 2008, p.229).
} 
agente de desenvolvimento rural nas diferentes áreas de atuação para o qual estão sendo preparados a atuar como futuros profissionais (UnB-FUP, 2009b).

A alternância na LEdoC não é apenas um a estratégia de escolarização que possibilite aos sujeitos do campo conjugar a formação com a vida produtiva, sem desvincular-se da cultura do campo, limitada a sucessão de tempos de formação justapostos, mas um princípio que define uma opção político pedagógica de desenvolver o processo formativo de educadores a partir de uma estreita conexão entre os dois tempos/espaços formativos, que concebe o estudantes como ator envolvido e atuante em seu meio, compreendendo-o como ser humano na complexidade da vida, dinâmica, em movimento (BARBOSA, 2012, p. 140).

A metodologia em alternância na LEdoC possibilita, então, a materialidade do Materialismo Histórico Dialético como método, seja na concepção, execução, avaliação e registro de todo o curso, seja na realização desta pesquisa-ação que ora apresentamos. Essa materialidade é possível pelo movimento de idas e vindas às comunidades e às escolas de inserção desses sujeitos, pois a cada Tempo Comunidade, quando os educadores voltam para suas comunidades levando levantamentos a realizar, textos para ler e discutir na comunidade e na escola, planejamentos de atividades a concretizar e refletir, emergem, em todo esse processo, os conflitos e as contradições existentes tanto na comunidade quanto na escola. Ali são discutidos esses conflitos e contradições, momentos de extrema riqueza e crescimento local são registrados por esses sujeitos e seus coletivos e, posteriormente, no próximo Tempo Escola, esses registros são trazidos e compartilhados com os colegas e docentes para gerarem discussões no âmbito acadêmico, em que os docentes, conjuntamente com esses educadores em formação buscarão respostas, subsídios e soluções para as situações registradas pelos sujeitos e seus coletivos.

Conforme nos mostra Barbosa (2012),

a alternância da LEdoC-UnB assume uma dimensão própria, estruturada em três dimensões, com suas respectivas estratégias pedagógicas:

I - Formação humana: para superar a lógica da escola capitalista é preciso romper com as relações sociais que a escola ensina e cultiva, pois condicionam um determinado modo de estar no mundo. Neste sentido, partimos da afirmação 
de que a alternância é uma práxis contra-hegemônica, e nos orientamos pelas seguintes perguntas:

Como articular a produção da vida e do conhecimento?

Como romper com a separação entre o conhecimento científico e a produção material da vida?

É preciso que os estudantes dominem toda a lógica que está por trás da produção material da vida, no campo e na cidade, construindo um conhecimento que dê conta da totalidade dos processos produtivos, não só como sujeito do campo, mas como sujeito da sociedade, conhecendo a sua lógica tecnológica, de construção da técnica, de construção das relações de produção, sendo capaz de discutir como a sociedade organiza o modo de produção material e o modo de produção do conhecimento.

A principal estratégia pedagógica é a construção de conhecimentos na própria dinâmica de Tempo Escola e Tempo Comunidade como tempos formativos alternados.

II - Relações sociopolíticas e culturais: orientamo-nos pela seguinte pergunta:

Como formar sujeitos capazes de formular e protagonizar um novo projeto de sociedade, um novo modo de se inserir nas relações sociais?

É preciso desconstruir as relações que impedem que estes sujeitos tenham autonomia e garantir que tenham conhecimento e experiência suficientes para se organizar, para pensar novos processos de produção e novas relações humanas. É central superar a subordinação da escola capitalista, substituindo-a por um processo de protagonismo e de construção de valores contra-hegemônicos, principalmente de solidariedade e cooperação, reconhecendo onde a competição e o individualismo prevalecem em nossas relações, como se manifestam e, a partir daí, buscar coletivamente meios de mudar os valores impressos em cada um pela sociedade capitalista em que estamos imersos.

As estratégias pedagógicas são:

- protagonismo dos estudantes: inserir o estudante no novo modo de organizar o trabalho pedagógico, buscando seu protagonismo na gestão dos processos formativos;

- auto-organização: do individual, desde a sua própria organização, até sua inserção na dimensão coletiva, criando diversas possibilidades de organização coletiva;

- trabalho como princípio educativo: tanto na sua dimensão concreta imediata de produção de valores materiais e de autosserviço como também no sentido criativo, de como nos colocamos diante das situações que exigem criação.

III - Relações de produção de conhecimento: o modo de produção do conhecimento é uma das dimensões em que a escola capitalista atua para reproduzir a lógica de subordinação e de fragmentação do conhecimento. É preciso mudar a forma com que a universidade lida com a produção de conhecimento para alterar a forma com que os estudantes vão lidar com o conhecimento em sua práxis docente na educação básica. A necessária mudança nas relações de produção de conhecimento prescindirá de: 
\# romper com a fragmentação do conhecimento, que não significa anular as especialidades, as especificidades, as fronteiras, mas ir além, fazer pontes, superar isolamento, construindo uma visão de totalidade. A fragmentação está não apenas entre as disciplinas, mas entre elas e a vida. É preciso promover 0 diálogo entre 0 conhecimento científico e a realidade concreta, e nesse movimento produzir conhecimento novo, o conhecimento que corresponde à vida;

\# transdisciplinaridade, ou seja, diálogo com a realidade, com outros conhecimentos que existem nos territórios, saberes construídos na produção da vida, de diversas fontes, atravessando não só as fronteiras entre os conhecimentos científicos, mas dialogando com conhecimentos procedentes da vida social.

A principal estratégia pedagógica é a articulação das disciplinas em blocos, formulada a partir dos seguintes princípios:

- articulação entre domínios teóricos e questões relevantes do movimento das territorialidades, ou seja, quais são só conflitos estruturais nos territórios, o que está acontecendo, o que os estudantes trazem das ações de inserção;

- formação do coletivo docente com diálogo entre as áreas de habilitação e os temas convergentes em cada etapa;

- distribuição de carga horária das disciplinas entre TE e TC, considerados espaços formativos com lógicas diferentes. Em TE temos a construção de conhecimento a partir da apropriação do conhecimento científico. Em TC trabalhamos conceitos a partir dos problemas da realidade (BARBOSA, 2013, pp. 141-143).

Assim, a ideia é que o trabalho pedagógico não se limite a tempo de aula, ou tempo de instrução, mas ao desenvolvimento da totalidade das dimensões humanas, que de acordo com Frigotto (2012), diz respeito a uma concepção de educação ou de formação humana em que são levadas em consideração as condições objetivas e subjetivas reais para o pleno desenvolvimento histórico dos sujeitos, "dimensões que envolvem sua vida corpórea material e seu desenvolvimento intelectual, cultural, educacional, psicossocial, afetivo, estético e lúdico" (FRIGOTTO, 2012 apud BARBOSA, 2012, p. 144). Dimensões essas que não advêm de uma essência humana abstrata, mas de um ser humano que se constitui nas relações sociais, tendo como fundamento o trabalho (BARBOSA, 2012, p. 144).

Já a formação pensada por áreas, na LEdoC-UnB, busca avançar e superar a fragmentação do conhecimento e, neste sentido, tenta caminhar para a construção de novas formas de produção de conhecimento pautadas na interlocução entre os diferentes campos da ciência. Assim, ao organizar os 
componentes curriculares por áreas do conhecimento para a composição do currículo, a LEdoC objetiva para se aproximar de uma práxis da multi e da interdisciplinaridade, pautando suas ações pedagógicas pelos princípios da diversidade e da criatividade intencionando, concomitantemente, a superação do isolamento disciplinar e a ruptura de fronteiras na direção de buscar uma leitura complexa da realidade (FERREIRA, 2014, p.56).

O Curso desenvolve-se em oito etapas (semestres) com carga horária total de 3525 horas/aula e 235 créditos, onde se formam educadores para atuar na gestão de processos educativos escolares e na docência nas áreas de Linguagens (Língua Portuguesa, Artes, Literatura) ou Ciências da Natureza e Matemática (Química, Física, Biologia e Matemática). Além disso, prepara os educadores para se tornarem sujeitos ativos para o trabalho formativo $e$ organizativo com seus pares na comunidade, ou seja, gestores dos processos educativos locais.

Algumas características dessa Licenciatura precisam ser evidenciadas neste documento para que o leitor compreenda que é condição indispensável, no curso, que novas práticas pedagógicas sejam construídas e exercitadas tanto pelo coletivo de docentes do curso, quanto pelos educadores em formação. Esse destaque é relevante no sentido de mostrar que para se promover mudanças significativas no modo de desenvolver o trabalho pedagógico, somente teoria não facilita a esses educadores em formação essa aprendizagem. Como diz Paulo Freire em sua Pedagogia da Autonomia, ensinar exige a corporeificação das palavras pelo exemplo. Para Freire,

Não há pensar certo fora de uma prática testemunhal que o rediz em lugar de desdizê-lo. Não é possível ao professor pensar que pensa certo mas ao mesmo tempo perguntar ao aluno se "sabe com quem está falando".

O clima de quem pensa certo é o de quem busca seriamente a segurança na argumentação, é o de quem, discordando do seu oponente não tem por que contra ele ou contra ela nutrir uma raiva desmedida, bem maior, às vezes, do que a razão mesma da discordância. Uma dessas pessoas desmedidamente raivosas proibiu certa vez um estudante que trabalhava dissertação sobre alfabetização e cidadania que me lesse. "Já era", disse com ares de quem trata com rigor e neutralidade o objeto que era eu. "Qualquer leitura que você faça deste senhor pode prejudica-la". Não é assim que se pensa certo o gosto da generosidade que, não negando a quem tem o direito 
à raiva, a distingue da raivosidade irrefreada (FREIRE, 1998, pp. 38-39).

Isto dito, voltemos às características essenciais à Licenciatura em Educação do Campo.

Iniciemos falando da matriz curricular, que propõe uma estratégia interdisciplinar de trabalho docente, cuja operacionalização se dá com uma organização dos componentes curriculares em três Núcleos estruturantes assim compostos e como mostra a figura 1 :

$\checkmark$ Núcleo de Estudos Básicos (NEB): Economia Política; Filosofia; Políticas Educacionais; Teoria Pedagógica; Leitura, Produção e Interpretação de Textos.

$\checkmark$ Núcleo de Estudos Específicos (NEE):

- Eixo 1: Docência por área de conhecimento: Linguagens (Linguística, Artes e Literatura); Ciências da Natureza e Matemática.

- Eixo 2: Gestão de processos educativos escolares.

- Eixo 3: Gestão de processos educativos comunitários.

$\checkmark$ Núcleo de Atividades Integradoras (NAI): Práticas Pedagógicas; Pesquisa; Estágios; Seminários Integradores; Outras atividades Científico-culturais (aqui se insere a Oficina de Informática - denominada mais tarde de CTI - Comunicação e Tecnologias da Informação). 


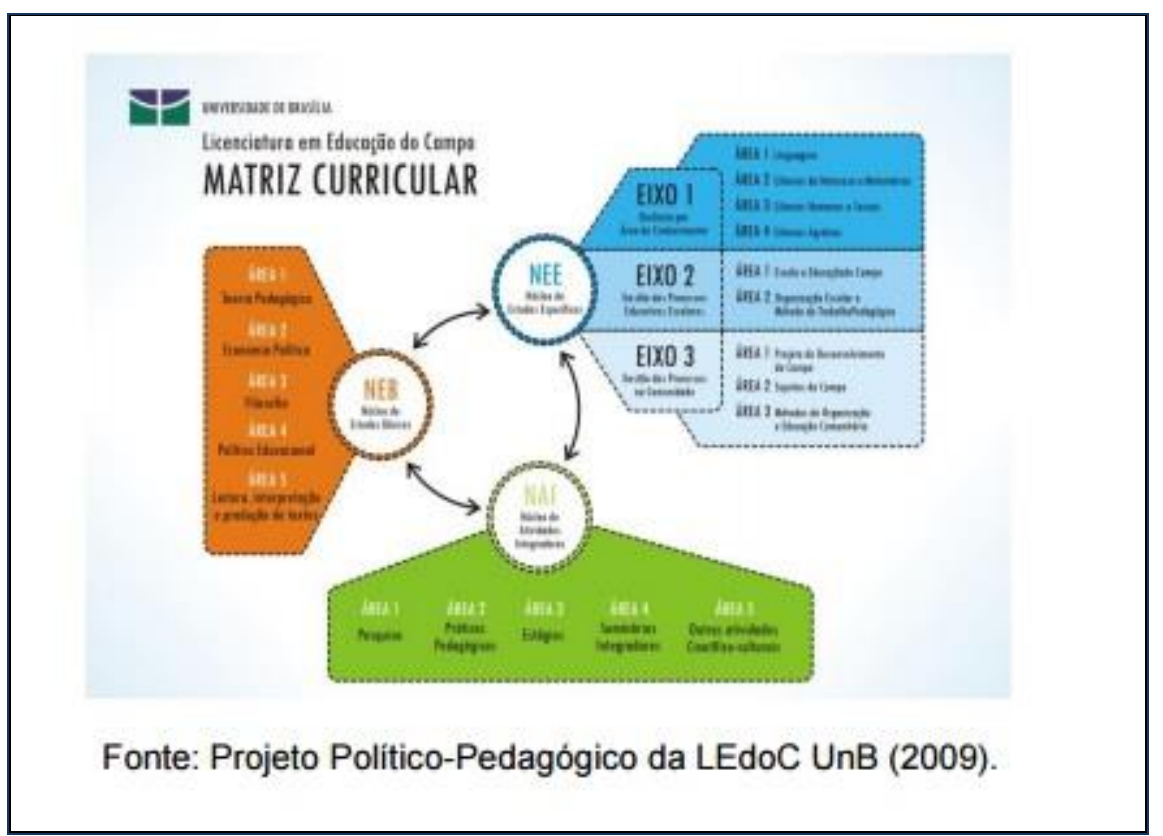

Figura 1: Matriz Curricular da Licenciatura em Educação do Campo - UnB

O perfil de ingresso definido na Minuta Original (MOLINA \& SÁ, 2011, p. 37) e mantido no Edital do Vestibular da UnB (que atende a um público de toda Região Centro-Oeste) era o seguinte:

a) professores em exercício nas escolas do campo da rede pública na Região Centro-Oeste que tenham o ensino médio concluído e não tenham formação de nível superior;

b) outros profissionais da educação com atuação na rede pública da Região Centro-Oeste que tenham o ensino médio concluído e não tenham formação de nível superior;

c) professores e outros profissionais da educação que atuem nos centros de alternância ou em experiências educacionais alternativas de Educação do Campo que tenham o ensino médio concluído e não tenham formação de nível superior;

d) professores e outros profissionais da educação com atuação em programas governamentais que visem a ampliação do acesso à Educação Básica da população do campo;

e) jovens e adultos de comunidades do campo que tenham 0 ensino médio concluído e não tenham formação de nível superior. 
Outra característica de caráter relevante na Licenciatura em Educação do Campo é o fato de que os princípios que regem as práticas formativas trazem como pano de fundo questões sobre as especificidades do perfil de educador do campo que se intenciona formar. Cabe ressaltar que, a LEdoC nasce comprometida não só com a escolarização dos sujeitos do campo, mas também e principalmente, nasce comprometida com a transformação das condições de vida do povo brasileiro que vive no campo (MOLINA \& SÁ, 2011, p. 39).

Assim, essa Licenciatura traz como princípios formativos gerais, conforme nos mostra Molina, são os que se seguem.

A concepção de educação, da expressão Educação do Campo, não pode abrir mão da necessária ligação com o contexto no qual se desenvolvem estes processos educativos: com os graves conflitos que ocorrem no meio rural brasileiro, em função dos diferentes interesses econômicos e sociais para utilização deste território. Esta concepção é constituinte, é estruturante de um determinado projeto de campo que, por sua vez é parte maior da totalidade de um projeto de sociedade, de nação. (...) A Educação do Campo compreende os processos culturais, as estratégias de socialização; as relações de trabalho vividas pelos sujeitos do campo em suas lutas cotidianas para manterem esta identidade, como elementos essenciais de seu processo formativo. Pela própria compreensão acumulada na Educação do Campo, sobre a centralidade dos diferentes tempos e espaços formativos existentes na vida do campo, nas lutas dos sujeitos que aí vivem e que se organizam para continuar garantindo sua reprodução social neste território, a ação formativa desenvolvida por estes educadores deve torna-los aptos a compreender e agir em diferentes espaços, tempos e situações (MOLINA, 2009, apud MOLINA \& SÁ, 2011, p. 39).

Desse modo, o processo formativo compreende: a formação escolar, a formação e preparação para gestão dos processos educativos escolares e a preparação para gestão dos processos educativos comunitários, isso tudo de forma articulada, de modo a construir as habilidades necessárias para que esses futuros educadores possam internalizar as condições de compreensão das relações da escola com a vida.

Inspirada na experiência de Pistrak (2000), a proposta curricular da escola do campo deve, necessariamente, vincularse aos processos sociais vividos, em um sentido de transformação social, articulando-se criticamente aos modos de 
produção do conhecimento e da vida presentes na experiência social (MOLINA \& SÁ, 2011, p. 40).

Para Molina \& Sá (2011), esta é uma condição fundamental para a educação possa contribuir, a partir das especificidades da via no campo, para a superação da alienação dos sistemas educativos em relação às transformações sociais.

A partir do exposto, tem-se como premissa que a concepção de escola do campo reconhece que esses são sujeitos de cultura e que sua formação deve partir dessa especificidade, mas que também é uma escola que se universaliza, uma escola unitária, onde a politecnia torne-se uma base para transitar entre os vários campos técnicos, para que a juventude rural possa acessar os direitos de qualquer cidadão da sociedade global e, ao mesmo tempo, ter alternativas para sua permanência no campo (MOLINA \& SÁ, 2011).

É preciso pensar a escola do campo para além dos conteúdos, trazendo novos valores e atitudes, lidando com todas as dimensões do ser humano. Mas isso só será possível se discutirmos em que base isso se dará, que princípios garantem que o sujeito do campo seja o centro do processo formativo, como sujeito que sempre traz seu o conhecimento e a construção histórica da sua cultura, de modo que, a partir daí, sejam capazes de fazer uma leitura do mundo tal qual ele se apresenta hoje à juventude, seja do campo, seja da cidade (MOLINA \& SÁ, 2011, p. 40).

Uma das principais, se não a principal dificuldade para que se promova essa conexão da escola com a realidade é colocar a escola na perspectiva da transformação social, buscando sentido contra-hegemônico a partir de valores e relações para que seja possível abandonar a exclusão e as desigualdades que caracterizam a escola capitalista. Os mecanismos de superação devem promover a busca da autonomia e da organização específica dessa escola, de acordo com Molina \& Sá (2011). E para Freitas, é preciso se questionar quais as dimensões devem ser transformadas na escola. Deve-se, então, levar em conta que as duas principais funções hegemônicas do sistema escolar são exclusão e subordinação e, a partir disso, buscar a mudança a partir do modo de produzir conhecimento (FREITAS, 2009 e 2010 apud MOLINA \& SÁ, 2011, p. 41). 
Baseada em Pistrak e com orientação de Luiz Carlos Freitas, especialista da área, a LEdoC iniciou a construção de novos procedimentos pedagógicos e passou a adotar como dimensões-chave:

$\checkmark$ uma matriz educativa multidimensional que permita ampliar a função social da escola;

$\checkmark$ o diálogo com as agências formadoras do meio;

$\checkmark$ o trabalho e o desenvolvimento humano integral como base da aprendizagem, superando a ênfase estritamente cognitiva da escola capitalista.

$\mathrm{Na}$ lógica do capital com sua necessidade tecnológica, o modo hegemônico de produção de conhecimento científico define a priori quais são as ciências básicas e como elas se hierarquizam. No processo contrahegemônico busca-se estabelecer uma matriz multidimensional para superar a ideologia da neutralidade científica e, para isso, são colocados em articulação os objetivos formativos e os instrucionais pensados numa realidade concreta, de modo que haja uma sintonia de educador e educando com a realidade a ser conhecida e explicada. Para que isso ocorra dentro dessa lógica, utiliza-se na LEdoC a metodologia dos Complexos de Estudo ou de Ensino conforme Pistrak (FREITAS, 2009 e 2010 apud MOLINA \& SÁ, 2011, p. 41).

Nessa metodologia, o pensamento é organizado por meio de conceitos e categorias a partir da consideração da complexidade do real como sendo uma síntese de múltiplas determinações, com muitas causas e relações simultâneas. Assim, selecionam-se algumas dessas relações e usa os conhecimentos científicos para compreendê-las. Então, para melhor definir,

Um Complexo de Estudo é esse conjunto de múltiplas relações que selecionamos, são escolhas de aspectos de uma realidade integrada, cuja compreensão recusa necessariamente 0 conhecimento fragmentado. O que conduz à integração não é o plano teórico, mas sim o modo como concebemos a realidade. Diversas disciplinas podem usar um complexo como palco para desenvolver seus conceitos. O importante é garantir a unidade teoria-prática (FREITAS, 2009 e 2010 apud MOLINA \& SÁ, 2011, p. 41).

Pistrak não descarta as contradições existentes na vida social, da qual, para ele também faz parte a escola. De uma escola isolada das contradições, 
passa-se a projetar uma escola onde se aprende a partir das lutas sociais e onde os trabalhadores do campo se preparam para a resolução das contradições no seu contexto de vida (PISTRAK, 2000 apud MOLINA \& SÁ, 2011, p. 42). Para ele,

O meio educativo se constitui pelos elementos da atualidade e suas contradições, e pela formação de uma rede de agências formadoras das quais as próprias famílias, os movimentos sociais $\mathrm{e}$ as diversas modalidades associativas podem ser componentes (PISTRAK, 2000 apud MOLINA \& SÁ, 2011, p. 42).

Dentro dessa metodologia dos complexos de estudo considera-se o trabalho como princípio geral educativo de inserção na realidade, incluindo, além do trabalho produtivo, o autosserviço, isto é, prestar serviços nos espaços coletivos. Alie-se a isso a formação para a auto-direção ou auto-organização, onde a construção do coletivo influencia a formação individual, descortinando as qualidades multiplicadoras e fortalecedoras da ação coletiva e o aprendizado moral e intelectual necessário para a fundamentação ética das novas relações sociais (MOLINA \& SÁ, 2011).

Pela perspectiva da educação, é crucial que nos processos
educativos formais - ensino básico, superior e educação
profissional - se faça a crítica a todas as formas de exploração
do trabalho, especialmente o trabalho infantil. Todavia, ao
mesmo tempo, é crucial que, desde a infância, se internalize a
compreensão de que cada ser humano tem o dever de, em
colaboração e solidariedade com os demais, buscar os meios
de vida e responder às múltiplas necessidades humanas. Daí
ser importante que mesmo as crianças, de acordo com a sua
possibilidade, participem de pequenas atividades ligadas ao
cuidado e à produção da vida. Isso nada tem a ver com
exploração do trabalho, mesmo no âmbito da família, sob a
forma de opressão pelo trabalho produtivo capitalista. Há que
se ter o cuidado de não retirar o tempo da infância que implica
o lúdico e os espaços formativos, pela exigência de tarefas
produtivas próprias para a vida adulta, porque, além de
prejudicarem o direito do tempo da infância, comprometem ou
deformam o desenvolvimento físico, social e psíquico da
criança (FRIGOTTO \& CIAVATTA, 2012, p.753).

Outra característica bastante relevante está relacionada ao modo de produção de conhecimento e à organização do trabalho pedagógico que é a não desvinculação das questões relacionadas à disputa dos modelos de desenvolvimento rural e de sociedade. Segundo Molina \& Sá (2011), o desafio pedagógico dessa proposta é criar um projeto educativo integral, coerente, que 
produza valores, convicções, visão de mundo, consciência organizativa, capacidade de ação, sentido pleno de ser humano, ou seja, trata-se de uma ruptura com o paradigma dominante no ensino e na pesquisa que tem outras tradições. Nesta perspectiva, é um trabalho que considera a realidade como exemplo ilustrativo da ciência; no caso da formação do educador do campo, trata-se de colocar a realidade como centro em torno do qual as ciências e outras formas de conhecimento se articulam, para que a realidade possa ser não apenas compreendida e analisada, mas também transformada. Desse modo,

Todo o trabalho centra-se no princípio da práxis, como modo de conhecimento que articula em um mesmo movimento teoria e prática; conhecimento e realidade. Assim, o trabalho pedagógico deve ser intencionalizado para que os estudantes desenvolvam a capacidade de elaboração própria e de prosseguir nos estudos de modo autodidata (MOLINA \& SÁ, 2011, p. 43).

Uma particularidade bem interessante da Licenciatura em Educação do Campo é que, por ser um curso em construção pode-se repensar e discutir determinadas estratégias e mudar o curso daquilo que não está dando certo, bem como acrescentar elementos que facilitam o trabalho ao mesmo tempo em que qualificam a formação. Importante modificação realizada foi a criação de um novo componente curricular denominado Conflitos Estruturais Brasileiros e Educação Popular (CEBEP). Este componente foi construído a partir da observação sobre os modos de percepção dos estudantes a respeito dos conflitos e contradições existentes em seus contextos de vida escolar e comunitária. CEBEP articula a compreensão da realidade brasileira à discussão sobre as estratégias educativas adotadas nas ações de inserção orientada nas escolas e nas comunidades. (MOLINA \& SÁ, 2011).

Almeja-se com esse procedimento contribuir para a leitura crítica dos educandos sobre a correlação de forças em sua comunidade e sobre as relações de poder que perpassam e definem o funcionamento do aparelho escolar. Visa-se também contribuir para a formação de educadores do campo capazes de identificar contradições no presente, situá-las no curso da história, em perspectiva de totalidade e formular estratégias de intervenção (MOLINA \& SÁ, 2011, p.51).

Tendo em vista que o planejamento de CEBEP é o trabalho de inserção orientada realizado em Tempo Comunidade, a partir das contradições 
dali decorrentes, não há uma fixação prévia de conteúdo e metodologia para cada etapa neste componente, já que as etapas se organizam a partir do foco estratégico indicado pela análise de conjuntura e da avaliação das táticas e estratégias adotadas em cada Tempo Comunidade e, de acordo com as especificidades regionais e locais (MOLINA \& SÁ, 2011, p.51).

Mais uma peculiaridade da LEdoC-UnB é a busca e priorização da Avaliação Formativa. Na perspectiva dessa Licenciatura, é formativa toda avaliação que auxilia o estudante a aprender e a se desenvolver, isto é, que colabora para a gestão das aprendizagens e do desenvolvimento no sentido de um projeto educativo (HADJI, 2001 apud MOLINA \& SÁ, 2011, p. 52).

Finalmente, mas não menos importante, é característica da LEdoCUnB entender a pesquisa como atividade estratégica articuladora do processo formativo, em que se realiza a integração pedagógica das atividades de estudo e construção de conhecimento no curso. De acordo com Molina \& Sá (2011), desenvolve-se como um conjunto articulado de ações formativas que respondem à necessidade de costurar teoria-prática, articulando conhecimentos ao mesmo tempo em que realiza uma intervenção social.

Esta concepção de pesquisa põe em prática um dos princípios fundamentais da Educação do Campo que é integrar ao processo de formação do educador uma estratégia individual e coletiva de intervenção social transformadora da realidade das escolas e comunidades do campo, por meio da produção de um conhecimento pertinente durante esse processo de intervenção, em diálogo com o conhecimento científico acumulado. Nesse sentido, trata-se de um exercício teóricoprático individual e coletivo de produção de conhecimento, voltado para os desafios de intervenção social identificados junto às escolas, comunidades e organizações sociais de origem dos estudantes (MOLINA \& SÁ, 2011, p 56).

E é nesse sentido que a Oficina de Informática, inicialmente pensada apenas como forma de instrumentalizar os sujeitos para o uso do computador e Internet durante a Licenciatura, vai se transformando em uma área de conhecimento que trabalha com a utilização de computador, Internet, celular e outras Tecnologias Digitais numa outra perspectiva que não aquela para a qual foram criadas, a da reprodução e da exclusão. Inicia-se um processo de discussão de novas formas de apropriação dessas Tecnologias de modo a utilizá-las nessa costura de teoria e prática, nesse processo de autoria e 
também nessa intervenção social na realidade desses sujeitos. No próximo tópico falamos um pouco sobre essa área de conhecimento e suas contribuições para a LEdoC-UnB.

\subsection{Tecnologias Digitais, Letramento Digital e Recursos Educacionais} Abertos

As Tecnologias Digitais apresentam-se como potenciais agregadoras das diferentes formas de entender, ler e se relacionar com o mundo. Do mesmo modo, elas podem ser entendidas, lidas e utilizadas sob diferentes perspectivas. Por essa razão, nem sempre seus usos são os que fazem bem à coletividade. Não se trata das tecnologias em si, mas dos usos feitos a partir da diversidade do ser humano, de suas crenças e valores. As tecnologias amplificam as vozes e seus sentidos podem, em segundos, ganhar o mundo, reafirmar valores e crenças, portanto, bem como desestabilizar verdades arraigadas, na medida em que possibilitam a confrontação imediata, que podem acoplar texto, imagem e som (PEÑA et.al., 2013, p. 195).

As tecnologias possibilitam diferentes formas de linguagem, leituras diversificadas sobre um mesmo texto, assim como também possibilitam variadas leituras de mundo. Além de propiciar essas leituras, também propicia a criação, a autoria, a produção, a construção de conhecimento e publicização desse.

A geração de vários sentidos ou possibilidades de expressão tem grande força nas tecnologias e pode estreitar as relações, à medida que não se reduzem à palavra escrita. Para comunidades com formas especialmente orais, há uma chance de registro, de exposição em tempo real mais completa e de maneira autônoma (PEÑA et.al., 2013, pp. 195-196).

Essas Tecnologias Digitais novas nos proporcionam formas variadas de registro que se ampliam através das redes sociais com a possibilidade de permeabilidade entre culturas. Essa possibilidade de acesso a outras culturas tanto pode enriquecer nosso repertório de imagens, sons, leituras, etc. como também pode gerar a motivação e o estímulo a essas formas de autoria e registro em quem as acessa, gerando assim um ciclo cultural universal.

Igualmente deve ser questionado se as Tecnologias Digitais são, em grande parte, geradas e difundidas por um universo ocidental capitalista, certamente seus filtros e formas de ação 
são gerados dentro dessa perspectiva, o que demandaria uma revisão dessa visão hegemônica (PEÑA et.al., 2013, p.196).

De acordo com Peña et.al. precisamos estar atentos ao fato de que a escolha cultural pode não ser feita de maneira consciente, pode ser feita pela falta de outras possibilidades, quando há a chance de entrar em contato igualitário em universos antes muitas vezes capsulares ou encapsulados. Melhor será uma escolha pessoal baseada em crenças e valores que façam sentido à pessoa, ou ao grupo em que sente algum pertencimento. Pode ser geograficamente comum, ou não. O espaço e o tempo, em certa medida, se rompem (PEÑA et.al., 2013, p.196).

As tecnologias difundem informação como potencialmente uma maneira de haver a permeabilidade entre culturas e dentro das mesmas culturas. Proporcionam o acesso a modos de viver pela divulgação do que ocorre em diferentes nichos sociais, em diferentes núcleos, desencadeando a aproximação entre estes. Pode-se pensar em uma aproximação pelas tecnologias, levando em conta a diversidade, como pode dar ao ser humano a possibilidade de entrar em contato com o ponto de vista do outro, humanizando o homem (PEÑA et.al., 2013, p.196). As tecnologias podem, ainda, permitir a aproximação e a articulação de movimentos sociais historicamente excluídos, no sentido de se comunicarem, mobilizarem e gerarem novos espaços e novas lutas contra-hegemônicas.

Em consonância com este contexto cultural provocado pelo dinamismo empreendido pelas Tecnologias Digitais, a sociedade passa por transformações profundas no modo de ver e conceber as relações, os bens de consumo, o conhecimento, os saberes, a educação, a política, a ética e a estética, bem como inicia um processo de apropriação dos artefatos do capital para gerar formas de diminuir a alienação da classe trabalhadora e de iniciar, com isso, um movimento rumo a um novo projeto societário. As tecnologias possibilitaram ampliar o campo educacional e democratizar o acesso à chamada educação aberta e também a recursos educacionais livres e abertos como os REA - Recursos Educacionais Abertos (PEÑA et.al., 2013). Desse modo, 


\begin{abstract}
A ampliação das possibilidades de acesso à educação passa, também, por uma profunda reformulação em suas bases conceituais. Um dos aspectos a ser considerado diz respeito aos materiais educacionais. Passamos de uma perspectiva consumista de produtos elaborados de forma centralizada para uma outra, aberta, que considera o educando como parte do processo de produção dos materiais (AMIEL, PRETTO, INUZUKA \& LIMA, 2012, p. 28).
\end{abstract}

Incorporando a ideia de conteúdo aberto, um neologismo cunhado por David Wiley em 1998 para designar qualquer material aberto com licença para utilização, adaptação e compartilhamento, foi que surgiram os REA,

Recursos Educacionais Abertos são materiais de aprendizagem, ensino ou pesquisa que estão em domínio público ou liberados com uma licença de propriedade intelectual que permita a livre utilização, adaptação e distribuição, em qualquer suporte ou mídia, incluindo software para criação e gestão de conteúdos (PEÑA et.al., 2013).

Para Peña e colaboradores (2013), REA inclui recursos de aprendizagem para apoiar os professores a utilizar e reutilizar REA, e recursos para proporcionar qualidade na educação e suas práticas.

\title{
2.4.1 Letramento digital e educadores do campo
}

Letramento é, segundo Soares (2002), o estado ou condição de indivíduos ou de grupos sociais de sociedades letradas que exercem efetivamente as práticas sociais de leitura e de escrita, participam competentemente de eventos de letramento têm as habilidades e atitudes necessárias para uma participação ativa e mantêm com os outros e com o mundo que os cerca formas de interação, atitudes, competências discursivas e cognitivas que thes conferem um determinado e diferenciado estado ou condição de inserção em uma sociedade letrada (SOARES, 2002, pp. 145146).

Costumamos dizer, de modo mais simplificado, que letramento é saber utilizar leitura e escrita para realizar práticas sociais, para resolver coisas do seu dia a dia. Para a maioria das pessoas da cidade, e principalmente para aquelas que nunca tiveram dificuldades sociais e econômicas, parece um conceito meio óbvio ao primeiro contato, no entanto, para as pessoas de classes sociais menos favorecidas e para aquelas que crescem no campo, não é tão simples assim. Além das dificuldades já anteriormente relacionadas à 
escolarização das pessoas do campo, ainda existem aquelas relacionadas ao acesso a serviços públicos em geral como banco, inscrições em editais, concursos, vestibulares, acesso a informações governamentais, entre outros. Alguns desses serviços já estão disponíveis no meio digital, em sites e portais disponíveis na Web, mas para sua utilização com eficiência e eficácia, outro tipo de letramento torna-se necessário: o letramento digital.

Para Xavier,
A competência para usar os equipamentos digitais com desenvoltura permite ao aprendiz contemporâneo a possibilidade de reinventar seu quotidiano, bem como estabelece novas formas de ação, que se revelam em práticas sociais específicas e em modos diferentes de utilização da linguagem verbal e não-verbal (XAVIER, S/D, p.3).

Ainda para esse autor, o aumento na utilização das novas ferramentas tecnológicas na vida social tem exigido dos cidadãos a aprendizagem de comportamentos e raciocínios específicos. Em razão disso, alguns estudiosos falam em um novo tipo, paradigma ou modalidade de letramento, que têm chamado de letramento digital. Esse novo letramento, segundo eles, considera a necessidade dos indivíduos dominarem um conjunto de informações e habilidades mentais que devem ser trabalhadas com urgência pelas instituições de ensino, a fim de capacitar o mais rápido possível os alunos a viverem como verdadeiros cidadãos neste novo milênio cada vez mais cercado por máquinas eletrônicas e digitais (XAVIER, S/D, p. 1).

Para Ferreira (2013),

o grau de letramento de uma pessoa é capaz de definir como ela vai agir, se afirmar, construir e sustentar uma visão de mundo partilhada por seu grupo. O que se diz com isso é que o letramento de um sujeito permite que ele carregue "traços identitários e significados compartilhados" (BUZATO, 2006) pelo coletivo do qual ele faz parte. Assim, pode-se entender o letramento como elemento da formação do sujeito que fortalece a relação do indivíduo com a coletividade à qual ele pertence. Isso acontece porque as práticas inerentes aos processos de letramento têm vínculos profundos com a sociabilidade e acontece muito em decorrência das necessidades dos indivíduos em se enxergarem como seres sociais (FERREIRA, 2013, p.49).

E, complementando o que dizem Ferreira (2013) e Buzato (2006), Araújo e Mercado (2010) afirmam que os diferentes níveis de letramento estão 
diretamente relacionados aos tipos de habilidades construídas e desenvolvidas pelos sujeitos em formação, não podendo ser pensadas, estas últimas, separadamente dos níveis de alfabetização do indivíduo, ou seja, pessoas que não se desenvolveram bem nos processos de alfabetização (leitura e escrita) podem apresentar avanços menos expressivos nos processos de letramento digital. Assim, suas habilidades comunicativas e sociais com o uso das Tecnologias Digitais serão tanto melhores desenvolvidas quanto tiver sido desenvolvido o processo de letramento alfabético desses indivíduos, tornandose o letramento alfabético e o letramento digital partes de uma tessitura de construção de conhecimentos em movimento contínuo (ARAÚJO \& MERCADO, 2010 apud FERREIRA, 2013, p. 50).

Então, neste trabalho utilizamos a definição de letramento digital como sendo

a situação do indivíduo que, conhecedor de técnicas e tecnologias digitais, é capaz de usá-las para agir no seu meio social, intervindo de forma transformadora nele (FERREIRA, 2013, p.51).

Assim, letramento digital seria um conjunto de condições construído a partir da relação e do aprendizado concernentes ao uso de computador e internet, cujos resultados incidam na melhoria e ampliação da capacidade dos sujeitos em aprender, entender e resolver questões relacionadas à política, economia, cognição e cultura em seu cotidiano social (op. cit.).

No caso dos sujeitos do campo, esse letramento mostra-se imprescindível, visto que o ciberespaço talvez seja um dos poucos "espaços" que possam chegar a todas as comunidades campesinas e suprir as dificuldades e ausências, citadas anteriormente, relacionadas ao acesso a serviços públicos, governamentais ou não, que atendam tanto aos interesses individuais, quanto aos coletivos desses indivíduos, de modo a gerarem impactos em sua vida econômica, social, cognitiva e cultural. Para isso, bastaria dotar essas comunidades de computadores, conexão à Internet e formação para esse uso.

Se pensarmos nos educadores do campo, também esse letramento pode ajudar a promover a transformação de sua prática pedagógica, seja por 
facilitar o planejamento dos momentos educativos; seja por dar acesso a soluções de formação a esses educadores; seja por ampliar os espaços de interação com outros educadores do campo, o que possibilitaria a formação de redes sociais voltadas para a melhoria da educação do campo em diversos níveis e âmbitos.

\subsubsection{Comunicação e Tecnologias da Informação - a formação para uso das Tecnologias Digitais em processos educativos}

Os elementos que aqui tratamos - Tecnologias Digitais - são claros representantes do fortalecimento dos movimentos do modo de produção capitalista: são instrumentos que colaboram com a globalização muitas vezes perversa como descreve Santos (2010), contudo, podem se tornar instrumentos em favor das classes oprimidas. É nessa perspectiva que lidamos com essas tecnologias nas aulas de Comunicação e Tecnologias da Informação, componente curricular da Licenciatura em Educação do Campo da UnB.

É de grande relevância para quem planeja refletir sobre usos de computador e Internet entender que o fato de tais tecnologias serem utilizadas com função segregadora e opressiva, em muitos casos, não quer dizer que elas não sirvam para melhorar as relações entre sujeitos. Segundo Santos (2010, p. 18), há a existência de pelo menos três mundos em um só: o mundo tal qual nos fazem vê-lo; o mundo tal como ele é, de fato; o mundo como ele pode ser. E aqui se pode construir outra globalização, menos cruel. Do mesmo modo, computador e Internet podem ser outra coisa para além de instrumentos do fortalecimento do modelo de desenvolvimento que ora temos.

Como qualquer outro objeto ou tecnologia, a Tecnologia Digital pode ser usada de várias formas e com diferentes finalidades, seja para reforçar ideologias do modelo de desenvolvimento pautado no capital ou para disseminar ações humanitárias. Neste novo cenário, onde as tecnologias têm papel importante, cabe repensar as estratégias de luta, refletindo sobre a não neutralidade da tecnologia que pode servir como instrumento para o domínio ou para a emancipação, fortalecendo a classe trabalhadora, ou, ainda, sendo usada para o incremento do capitalismo como eficiente mecanismo para a dominação (MORAES \& MONIZ, 2013). 
Destacamos como importante, na perspectiva da inserção dos sujeitos do campo nos processos de acesso e uso de computadores e Internet, que seja necessário fazer conexões entre saberes locais e saberes globais, dotando de oportunidades de conhecimento de mundo e de desenvolvimento as comunidades do campo, e, potencialmente, o ciberespaço pode ser elemento de interlocução, possibilitando, aos sujeitos do campo, capacidade de acesso a informações que auxiliem na melhoria da produção agrícola familiar e no desenvolvimento cognitivo, político e cultural (CASTRO, 2011; FERREIRA, 2013).

De acordo com os estudantes da LEdoC-UnB, existe a necessidade real de fortalecimento de estratégias que promovam o desenvolvimento rural, sem que os sujeitos do campo precisem sair definitivamente de seu ambiente de vivência, estudo e produção de vida. Pois, o acesso às informações por meio do uso de computador e Internet pode alterar positivamente a vida no campo, o modo de trabalho, as técnicas de cultivo autossustentáveis e ecologicamente adequadas, enriquecendo, ainda, às práticas pedagógicas com inovações que ampliem a qualidade dos processos educativos locais (CASTRO, 2010; FERREIRA \& CASTRO, 2011; FERREIRA, 2013).

$\mathrm{Na}$ distribuição das áreas de conhecimento da LEdoC-UnB há um componente curricular denominado Oficina de Informática que foi pensado inicialmente como um tempo-espaço educativo com carga horária de 8 horasaula em cada Tempo Escola (semestre). No âmbito deste componente curricular, os educandos da LEdoC-UnB deveriam ser iniciados no mundo do uso da informática, aprendendo, especificamente usos elementares de computador e Internet. Isso deveria acontecer nos laboratórios de informática da própria Universidade de Brasília, especificamente onde os educandos passaram a ficar a partir de 2010: a Faculdade UnB Planaltina (FUP). Todavia, as discussões sobre tecnologia de um modo geral, Tecnologias Digitais no campo, as primeiras aproximações dos educandos com o uso instrumental acadêmico de computador e Internet, as primeiras estruturas de oferta de computador e Internet para uso coletivo, acompanhados pelos docentes voluntários (nós) já aconteciam no decurso de 2009 (FERREIRA, 2014, p.62). 
A ideia original foi modificada quando propusemos a realização deste processo educativo voltado, em primeiro plano, à discussão da comunicação contemporânea onde atividades de manipulação da informação construídaspesquisadas seriam realizadas usando computadores da FUP. Deslocamos a prioridade do aprendizado técnico do uso do computador para a discussão crítica dos processos comunicacionais atuais sistematizando, instrumentalmente, tal discussão, em aparatos digitais diversos como Redes Sociais (Twitter, Orkut, Facebook), textos, blogs, Ambientes Virtuais de Aprendizagem, Softwares de manipulação de imagens e vídeos, apresentações de slides eletrônicos, etc. (FERREIRA, 2014, p.63).

O componente denominado Oficina de Informática, constante do PPP original da LEdoC-UnB, passou, então, a ser chamado de Comunicação e Tecnologias da Informação (CTI) e sua ementa é a seguinte: abordagem crítica das Tecnologias de Informação e Comunicação (TIC); o uso social do computador e da Internet; noções de Software e Hardware; Sistema Operacional: comandos básicos; usos comuns da Web: comunicar, comprar, aprender, ensinar, brincar; acesso à Internet: conhecer elementos do navegador e símbolos (ícones) de navegação; pesquisa na Internet; criação de conta de e-mail: endereço virtual; espaços virtuais e suas possibilidades educativas; usos do computador e da Internet na educação; Letramento digital.

A inserção de novas Tecnologias Digitais implica mudanças que não passam apenas pelo querer dos docentes, mas por todo o sistema e dependem, para terem sucesso, de transformação na organização da escola, na dinâmica de sala de aula (o que também considera o número de educandos por turma), no papel do educador e dos educandos e na relação com o conhecimento. É preciso educar de modo a construir, também, novas formas de relacionamento com o conhecimento e com os sujeitos deste. É necessário sair da perspectiva de que os saberes só a alguns pertencem, afinal todos somos produtores de conhecimentos e não há porque mantermos as relações hierarquizadas em relação ao saber (CASTRO, 2008).

Oliveira (2006) também afirma posicionamento semelhante quando diz que a compreensão das múltiplas relações em que o indivíduo está inserido deverá ter como proposta de educação um modelo completamente diferente 
daquele que se tem caracterizado em nossa sociedade, em que se compreende o fenômeno educativo como pura transmissão do saber, colocando o aprendiz como mero receptor de informações, incapaz de desenvolver a criticidade sobre informações e saberes trabalhados, por isso mesmo, alheio à necessidade de transformação da realidade social vigente.

Também Freire (1997) afirma que

a Educação que se impõe aos que verdadeiramente se comprometem com a libertação não pode fundar-se numa compreensão dos homens como seres 'vazios' a quem o mundo 'encha' de conteúdos; não pode basear-se numa consciência espacializada, mecanicistamente compartimentada, mas nos homens como 'corpos conscientes' e na consciência como consciência intencionada ao mundo. Não pode ser a do depósito de conteúdos, mas a da problematização dos homens em suas relações com o mundo (FREIRE, 1997, p.67).

No nosso entender, a formação docente precisa restituir ao educador a possibilidade de controlar seu trabalho, de construir seu saber, de buscar a função social da escola onde ele atua, de definir com que concepção de educação ele trabalha, o que exige, segundo Arroyo (2000 apud CASTRO \& FERREIRA, 2011, p.10), a redefinição da função do especialista (docente), supostamente responsável pelo controle do produto e da função social da escola e que na sociedade atual necessita se situar em um novo paradigma, com novos sujeitos envolvidos, que pensam diferente, se relacionam diferente e aprendem saberes diferentes daqueles aprendidos na maior parte dos cursos de formação docente.

As Tecnologias Digitais e, em especial, o computador e o acesso à Internet, têm proporcionado aos indivíduos novas formas de aprender e de pensar. A expansão de possibilidades nessas formas de aprendizagem não prescinde da relação educativa e do importante papel do mediador/facilitador como articulador dos saberes a serem construídos pelos sujeitos (CASTRO, 2007). O papel do educador precisa se transformar assim como e com tanta velocidade quanto se transformam as novas formas de aprendizagem.

O professor é, em sua essência, um pesquisador e deve ser um constante aprendiz, deve ser um formulador de problemas e dúvidas que 
incitem os educandos, deve ser um parceiro. Segundo Fagundes (S/D), as novas funções do educador são exigentes: ele precisa tornar-se um orientador confiável, um negociador nas buscas de problematização e testagens das informações disponíveis nas fontes da rede mundial e, sobretudo, nas buscas de novas respostas. Para Moraes (1997), a qualidade educativa é possível, pois,

as instrumentações eletrônicas, se adequadamente utilizadas em educação, poderão se constituir em ferramentas importantes capazes de colaborar para a melhoria da qualidade do processo de aprendizagem, estimulando a criação de novos ambientes educacionais e de novas dinâmicas sociais de aprendizagem, colaborando, assim, para o surgimento de certos tipos de reflexões mentais que favorecem a imaginação, a intuição, a capacidade decisória, a criatividade, aspectos estes fundamentais para a sobrevivência individual e coletiva (MORAES, 1997, p. 09).

Durante muito tempo o computador tem sido utilizado apenas como ferramenta de apoio ao educador e ao educando. As principais atividades, em algumas escolas, continuam tendo como centro a fala do professor e a relação com os textos escritos e livros didáticos. É como se a situação tradicional, conservadora e conteudista se transportasse para o computador. Os conflitos e as contradições não fazem parte da relação educativa na maior parte das escolas.

Um ponto crucial que os estudiosos da área questionam está relacionado à formação dos educadores para atuação com as Tecnologias Digitais, pois sem o conhecimento técnico instrumental o educador fica refém de pessoas que detenham esses conhecimentos.

Em nosso entendimento, faz-se necessário que sejam observados dois aspectos essenciais para 0 uso de Tecnologias Digitais nos processos educativos:

- a construção de conhecimentos técnicos e pedagógicos (por educadores) relacionados ao uso de Tecnologias Digitais em processos educativos deve acontecer concomitante, sem que se privilegie um ou outro. Ambos são necessários à atuação docente em uma nova perspectiva; 
- para que esse uso seja eficiente e eficaz, faz-se imprescindível observar as especificidades da cada tecnologia com relação às aplicações pedagógicas. O educador deve conhecer o potencial que as tecnologias e mídias têm a oferecer e como pode ser explorado nas situações educativas.

Ambos são complicadores para o público com o qual trabalhamos, pois essas tecnologias são muito dispendiosas e a Internet, quase inexistente em boa parte das comunidades atendidas, conforme informações dos próprios educandos no questionário aplicado. Os poucos que dispunham de Internet em casa, relatavam que o computador era antigo e não comportava programas e aplicativos mais avançados por falta de memória, principalmente.

No entanto, essa era uma realidade quando do ingresso dos educandos na LEdoC, pois ao final do curso, constatamos que $85 \%$ dos educandos já eram proprietários de um notebook e grande parte desses já dispunha de Internet 3G. Isso, conforme nosso entendimento, já é reflexo da importância de CTI para esse coletivo e também individualmente.

\subsubsection{Síntese das aulas em CTI}

O que nos moveu a propor a inserção de uma área de conhecimento que tratasse a apropriação das Tecnologias da Informação e Comunicação na LEdoC foram, inicialmente, os diálogos com os estudantes que adentravam ao Curso ao final de 2008. Tratava-se da 2a Turma da LEdoC da UnB e da primeira turma em Brasília cujo semestre iniciou-se efetivamente em fevereiro de 2009 com 56 estudantes.

Quando indagamos aos estudantes da LEdoC-UnB sobre a relação da Escola do Campo com computador e Internet recebemos como resposta que, na maioria dos casos, isso não acontecia, ainda, por uma série de fatores, dentre os quais se destaca: "falta de equipamentos e conectividade, ausência de formação de docentes para utilização desta tecnologia, descaso dos governos em relação às Escolas do Campo [...]" (CASTRO, 2011, p. 6).

Para uma melhor visualização do componente curricular Comunicação e Tecnologias da Informação, as estratégias didáticas mais gerais de CTI podem ser assim descritas: 
No Tempo Escola - TE:

1. introdução ao período de aula com breve explanação de um dos educadores acerca da articulação entre vários conceitos permeadores. Chamamos de conceito permeador aquele conhecimento crítico sobre os movimentos da sociedade (com centralidade no trabalho) que, a cada conteúdo específico da área, permeia as discussões e que tem por finalidade trazer à tona reflexões sobre a necessidade de transformação social por meio de um novo projeto de campo e de sociedade que contraponha ao sistema do capital;

2. descrição dos objetivos da aula, lembrando aos educandos para olharem os conteúdos de modo crítico (com base nos conceitos permeadores de cada aula e das aulas anteriores);

3. apresentação, discussão e atividades diversas relacionadas aos conteúdos propostos em diversas mídias;

4. síntese individual e depois coletiva sobre os conteúdos; registro, pelos educadores, das sínteses; confirmação com os educandos sobre a validade da transcrição feita pelos educadores de suas falas individuais para uma representação coletiva.

No Tempo Comunidade - TC:

1. os educandos eram estimulados a pensarem a articulação dos conteúdos estudados no Tempo Escola com a sua realidade de vida nas comunidades e, na medida do possível, realizar o registro dessas reflexões.

No Tempo Escola subsequente:

1. a título de memória, os conteúdos trabalhados na aula do TE anterior eram brevemente revisitados;

2. a síntese do TE anterior era lida novamente e perguntávamos, em quê e como, tais conteúdos se relacionavam à sua vida na concretude da comunidade;

3. uma nova síntese era elaborada como registro de todo esse processo; era lida e confirmada pelos educandos. 
Caso o leitor queira saber mais sobre cada uma das aulas desenvolvidas, trazemos as sínteses produzidas coletivamente pela turma ao final de cada aula no Apêndice B.

\subsubsection{História e conceito de REA}

Mas o que são Recursos Educacionais Abertos? Voltemos um pouco para melhor recordamos sua significação. De acordo com a definição de Starobinas, REA são:

materiais de ensino, aprendizado, e pesquisa em qualquer suporte ou mídia, que estão sob domínio público, ou estão licenciados de maneira aberta, permitindo que sejam utilizados ou adaptados por terceiros. O uso de formatos técnicos abertos facilita o acesso e o reuso potencial dos recursos publicados digitalmente. Recursos educacionais abertos podem incluir cursos completos, partes de cursos, módulos, livros didáticos, artigos de pesquisa, vídeos, testes, software, e qualquer outra ferramenta, material ou técnica que possa apoiar o acesso ao conhecimento (STAROBINAS, 2012, pp.122-123).

A definição coloca foco na diversidade de materiais de ensino, aprendizado e pesquisa que rompem com uma tradição de propriedade, na qual, a priori, é proibida a utilização e a adaptação de qualquer material produzido por outrem, sem expressa autorização de seus detentores de direitos autorais. Segundo Starobinas (2012), essa mudança de postura, anunciada na adoção de licenças livres, pode constituir um estímulo para que educadores partam em busca de conteúdos que possam promover a aprendizagem de forma mais interessante em seus cursos. Mais que isso, a abertura para a adaptação viabiliza a transformação de um conteúdo estático em um conteúdo dinâmico, possibilitando, também, a contextualização desse material para facilitar a compreensão de seu conteúdo pelos educandos. Sob o ponto de vista político e autoral, os REA estão sob domínio público ou licenciados de maneira aberta.

O termo Recurso Educacional Aberto foi adotado no Fórum da UNESCO de 2002 sob o impacto do Open Courseware para a Educação Superior em Países em Desenvolvimento (1st Global OER Forum). Este fórum reuniu 20 especialistas de diversos países. A ata final do evento sintetiza a adoção do termo Recurso Educacional Aberto. 
Como conclusão do Forum on the Impact of Open Courseware for Higher Education in Developing Countries, organizado pela UNESCO, os participantes expressaram sua satisfação e o seu desejo em desenvolver, juntos, recursos educacionais universais disponíveis para toda a humanidade, a serem referidos de agora em diante como Recursos Educacionais Abertos.

E em 2005 a UNESCO cria OER Community Wiki para dividir informações e trabalhos colaborativamente em torno da produção e uso de REA. Também em 2005 é criado o OpenCourseWare Consortium, uma comunidade mundial formada por instituições de educação e organizações associadas que estão comprometidas com o avanço do OpenCourseWare e seu impacto na educação global. A comunidade é focada em prover acesso a materiais educacionais de alta qualidade. Neste período, muitas outras instituições e organizações aderem ao movimento e criam comunidades, cursos, estruturas para a difusão de REA.

Inspirado no sucesso do movimento de software livre e da iniciativa OpenCourseWare (OCW) do Massachusetts Institute of Technology, é cada vez mais é crescente no ambiente acadêmico, a ideia de disponibilizar cursos e conteúdos de forma livre e aberta. Os Recursos Educacionais Abertos (REA), mas conhecidos por sua sigla em inglês OER (Open Educational Resources) são recursos voltados para o ensino, aprendizagem e pesquisa, disponibilizados de forma livre e aberta para a comunidade acadêmica em geral (DUTRA \& TAROUCO, S/D, p. 1).

O movimento é baseado no princípio de que o conhecimento é um bem público. Está enraizado na filosofia de abertura, que considera o conhecimento um produto social coletivo e, portanto, uma propriedade social (DOWNES, 2007 apud PEÑA et.al., 2013, p.197).

O Projeto sobre Recursos Educacionais Abertos: desafios e perspectivas, criado em 2008 no Brasil, foi um dos pioneiros a tentar se apropriar da realidade e das perspectivas brasileiras em uma discussão internacional sobre o assunto. No ano de 2012, o Brasil sediou para a América Latina um dos Fóruns de Políticas Regionais promovidos pela UNESCO e Commonwealth of Learning (COL) para preparar o evento maior que ocorreu em julho de 2012 em comemoração aos 10 anos de adoção de REA. 
Nesta direção, a UNESCO, com o objetivo de envolver a comunidade em torno do REA (práticas, projetos, pesquisa) através de uma identidade comum, adotou uma marca que, adaptável em diversos idiomas, é capaz de simbolizar, em diferentes culturas, o significado dos Recursos Educacionais Abertos: educação humana, liberdade, progresso, difusão, não exclusão, abertura, colaboração, crescimento. Os símbolos são o pássaro para liberdade, o livro aberto e a mão direita para a doação, conforme figura 1.

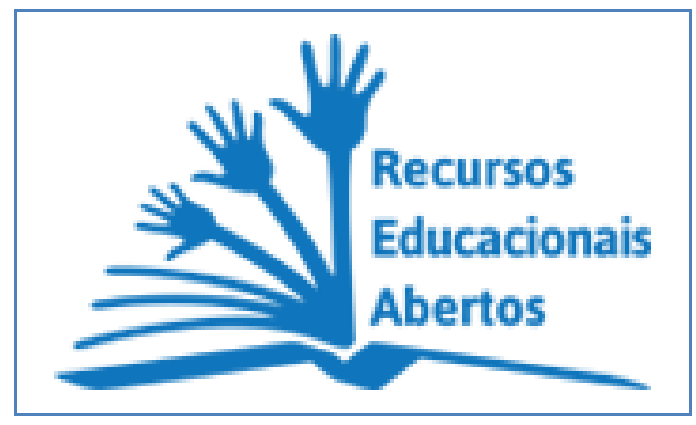

Figura 2: Recursos Educacionais Abertos

Segundo Wiley (2005 apud DUTRA \& TAROUCO, S/D), o termo Open Educational Resources tem suas raízes nos primeiros esforços na padronização e conceituação dos objetos de aprendizagem. Com a evolução da utilização dos objetos de aprendizagem Wiley definiu em 1998 o conceito de Open Content e criou a Open Content License/Open Publication License, visando a popularização dos conceitos do movimento FLOSS aplicados ao desenvolvimento de conteúdos educacionais. Com a rápida disseminação da ideia de conteúdos abertos indo além do escopo educacional, em 2001 Larry Lessig e outros membros da escola de direito de Harvard, fundaram a Creative Commons e com ela um conjunto flexível de licenças (DUTRA \& TAROUCO, S/D, pp. 2-3). A Creative Commons, então, é uma organização que busca dar suporte e infraestrutura legal para a distribuição de criações digitais. Pelo grande uso destas licenças em repositórios como o Wikimedia Commons, o Flickr Commons, e por ser de fácil compreensão para indivíduo, torna-se grande apoiador da disseminação dos REA.

São as Licenças Legais (CC licenças) que permitem o uso e o compartilhamento de materiais que, em um olhar ampliado, ajudam a promover 
o compartilhamento do conhecimento. Com parte da inspiração vinda do GNU General Public License (GNU GPL) - elaborado pela Free Software Foundation, que promove a ideia do software livre, em 2002 foi lançado o primeiro conjunto de licenças de forma livre e gratuita para o público.

Para relembrar ao leitor, o projeto GNU (GNU's not Unix) foi lançado por Richard Stallman, cientista do Massachusetts Institute of Technology - MIT, que tinha a pretensão de criar um sistema operacional do tipo Unix gratuito, em função do desagravo de muitos programadores que haviam contribuído para o aprimoramento do Unix e consideravam injustos que grandes empresas se apropriassem do fruto deste trabalho. Para organizar o trabalho do projeto GNU, Stallman e outros criaram a Free Software Foundation (FSF), uma corporação sem fins lucrativos que busca promover softwares gratuitos eliminando restrições à cópia, redistribuição, estudo e modificação do mesmo formulando assim a licença GPL (GNU General Public License), isso no ano de 1985.

Em 1989, um estudante finlandês chamado Linus Torvalds inicia um processo pessoal de aprimoramento do Kernel do Minix um sistema operacional do tipo Unix escrito por Andrew Tannenbaum, chamando esta vertente de Linux como abreviação de Linus's Minix. E assim surgiu o Linux. E desde essa época o movimento de software livre, conhecido também como movimento FLOSS (Free Libre and Open Source Software), tem se consolidado (DUTRA \& TAROUCO, S/D, p. 1).

Estes movimentos (copyleft, domínio público), em conjunto com o Creative Commons, contribuem para a reorganização do entendimento do direito autoral, da propriedade intelectual e das licenças abertas e livres, para evitar que aquilo que é público torne-se ao longo do tempo privado, quebrando o círculo virtuoso da cocriação.

$O$ acesso aberto a estes recursos deve ser dado por um conjunto de condições que propiciem ações criativas de construção de REA e de compartilhamento destes recursos para contribuir para uma educação aberta ao longo da vida e de forma consistente. Nesta direção temos algumas das condições importantes, segundo a Organização para a Cooperação e 
Desenvolvimento Econômico (OCDE) - Centre for Educational Research and Innovation (CERI) - (OCDE, 2007 apud PEÑA et.al., 2013, p.199):

- criar pontes entre a aprendizagem formal e informal;

- tratar questões filosóficas sobre a natureza da propriedade e da validade do conhecimento e de conceitos como altruísmo e bens coletivos;

- perceber novas formas de compartilhar conhecimento;

- perceber o uso do conhecimento como chave para o desenvolvimento econômico;

- entender também como razões para indivíduos e instituições usarem, produzirem e compartilharem REA: a perspectiva tecnológica, econômica, social e legal;

- visualizar a perspectiva de que os REA devem afetar currículo, pedagogia e avaliação.

A ideia de abertura fica assim consolidada dentro de uma ecologia social humana que incorpora flexibilidade, inovação, a perspectiva de estar sempre em mudança, preceitos de pedagogia e democracia. Isto nos leva a entender o REA como um fenômeno resultante da emergência da participação criativa, da liberdade de ação onde todos somos coautores da construção e distribuição mais generosa de conhecimento. Mas, também, nos dá a real dimensão das implicações deste movimento, das barreiras e dificuldades para a sua efetivação (PEÑA, 2013).

Cabe aqui ressaltar que a OCDE solidificou-se como organização condutora da reconstrução europeia no pós II Guerra Mundial e articuladora das relações centroperiferia do capitalismo mundial tendo como princípio norteador o fomento ao desenvolvimento econômico associado à flexibilização das barreiras comerciais e à estabilização social cristalizada a partir da melhoria da educação evidenciada pelos resultados dos testes implementados, no caso do Brasil o Programa Internacional de Avaliação de Estudantes (PISA). $E$, embora tenhamos citado a OCDE, não comungamos de sua política de fortalecimento do capitalismo mundial. Como foi essa Organização que compilou as condições para uso, criação e remixagem de REA, não poderíamos deixar de citá-la por participar da história do Movimento por REA. 


\subsubsection{Recursos Educacionais Abertos - REA e Educação do Campo}

Os REA nascem de um movimento politico em direção à democratização da educação e é nesta área que eles potencialmente e desenvolveram, havendo uma infinidade de REA dispersos na web (PEÑA, 2013, pp.199-200).

Anualmente, uma quantidade imensa de dinheiro público (da ordem de milhões) é gasta pelos governos na compra de materiais didáticos impressos e digitais que não são REA e, portanto, são de acesso restrito, inibindo as possibilidades de reprodução, criação e adaptação de conteúdos por educadores e estudantes (GONSALES, 2014, p.53).

O livro didático, segundo essa lógica, deveria desonerar o professor da trabalhosa tarefa de selecionar seus materiais de trabalho e pensar em suas formas de atuação (STAROBINAS, 2012). Por outro lado, deveria apresentarse como uma garantia mais avalizada de conteúdos de qualidade, no entanto isso não procede. Por mais que sejam feitos a partir de conteúdos e estratégias contextualizados, os livros didáticos têm grande dificuldade de atender às especificidades que cada comunidade tem, principalmente, as comunidades do campo.

É preciso garantir cada vez mais espaço para uma aprendizagem que dê lugar ao diálogo com um repertório cultural menos restrito e que aposte na investigação crítica, demandando uma postura de participação ativa de todos os envolvidos no processo.

No caso das escolas do campo, a situação é um tanto mais preocupante, pois existe o Programa Nacional do Livro Didático do Campo PNLD Campo que deveria garantir livros didáticos específicos para as populações do campo a partir de suas especificidades, mas que, infelizmente, não consegue atender às demandas culturais, históricas, sociais e linguísticas dessas comunidades.

No edital no PNLD Campo do Ensino Fundamental: Anos Iniciais até há uma intenção de contemplar as especificidades do campo, mas nos demais níveis e modalidades isso não ocorre, por não haver PNLD Campo para os outros níveis. 
Tratar o chamado material didático como Recursos Educacionais Abertos (REA) pode contribuir para um processo de transformação muito positivo para a aprendizagem escolar. $\mathrm{O}$ adjetivo "aberto" se contrapõe às receitas prontas e aos textos que encerram em si toda e qualquer resposta. $\mathrm{O}$ convite que essa "abertura" dos recursos educacionais nos traz é de oferecer um pouco de nós, de nossas ideias, das ideias de nossos educandos, para enriquecer nossos materiais e compartilhar nossos rastros com qualquer outra pessoa que queira neles se inspirar. Muitos educadores incluem em suas propostas de trabalho, de uma forma ou de outra, recursos que vão além do uso puro e simples dos livros didáticos. A adoção mais explícita de REA, entretanto, aponta para uma transformação que vá além de iniciativas isoladas. Cabe, portanto, uma reflexão mais focada nesses ganhos em potencial (STAROBINAS, 2012, p.124).

Pensar em práticas pedagógicas com 0 uso de REA na sua estruturação condiz com uma diretriz importante salientada nos marcos educacionais contemporâneos: a busca de interdisciplinaridade. Propor a abertura dos recursos educacionais é também uma oportunidade de trabalhálos fazendo uso conjunto de diferentes referenciais disciplinares (STAROBINAS, 2012). Isso vale tanto na articulação para compreender um determinado fenômeno, quanto para a produção de outros recursos, que podem surgir como desdobramento de um projeto: textos, vídeos, softwares, apresentações, etc. $O$ enfoque interdisciplinar nos permite ganhos no compartilhamento do conhecimento e da criatividade dos diferentes profissionais e também dos educandos.

Na prática que leva à concretização desse tipo de proposta, trata-se, por um lado, de selecionar e reunir os diferentes REA que servirão de ponto de partida - tendo em mente que outros poderão se agregar ao longo do caminho. Por outro, essas são atividades especialmente ricas para que os retornos da aprendizagem possam ser elaborados na forma de novos REA, igualmente fazendo uso de habilidades que ultrapassam as fronteiras disciplinares (STAROBINAS, 2012, p.125).

A adoção de REA pode ajudar a promover a superação de um modelo de passividade nas práticas educacionais escolares, tanto no que diz respeito à atuação dos educadores, quanto na dinâmica dos educandos. Colocar-se diante dos recursos didáticos, inclusive do livro didático, como quem pode 
transformá-lo é um passo essencial para uma postura mais autoral em relação ao próprio trabalho e para romper com uma expectativa de educandos que sejam consumidores acríticos de blocos de informação, como é propagado pela capital (STAROBINAS, 2012, p.127).

Afinal, para o professor, promover a aprendizagem é colocar-se a cada ano diante de novos alunos, com reações inesperadas às propostas de trabalho que temos a lhes oferecer, em contextos históricos que variam. E, dessa forma, não se trata apenas de um professor que se coloca como promotor da aprendizagem de outrem, mas como alguém que aprende também, mediado por aquele coletivo que pergunta, que comenta, que reage de formas diferenciadas aos estímulos que trazemos (STAROBINAS, 2012, p.127).

O educador que percebe, a final de uma aula, que poderia melhorar o material que utilizou para responder melhor às necessidades de seus educandos, passa a ter nesses parceiros potenciais coautores nos próximos materiais.

Esse educador também pode aproveitar o interesse dos educandos para propor que eles mesmos criem novos materiais aprimorando aquele ou criando novos materiais a serem compartilhados. Imaginemos esses materiais disponíveis em rede e sendo produzidos, utilizados, reformulados e compartilhados por educadores e educandos do campo (STAROBINAS, 2012).

A expansão de uma cultura de uso de REA na educação básica passa pela inclusão de educadores e educando na cadeia de autoria, seja no dia a dia, nas atividades previstas na matriz curricular, seja estimulando iniciativas de produção de conteúdos relacionados à cultura da comunidade em que vive e em que a escola está inserida, trazendo depois para a própria escola para compartilhar as experiências e estimular mais e mais produções. Seria uma espécie de documentação de seu percurso educacional.

Saindo das pastas dos professores e das gavetas dos alunos para povoar a rede, associados a licenças abertas e indexados de forma a facilitar sua localização, a produção dos sujeitos da aprendizagem na escola pode assumir sua função social de elos na cadeia da construção do conhecimento. Esse é o momento de realimentação do acervo de REA na internet, permitindo a abertura de outros ciclos de inspiração e produção (STAROBINAS, 2012, p.129). 
Em nosso entendimento, a cultura de adoção dos Recursos Educacionais Abertos nas escolas públicas e, principalmente, nas escolas do campo, pode promover inúmeras melhorias nas práticas pedagógicas gerando uma revolução no aprendizado das comunidades aprendentes.

\subsubsection{Criação, adaptação, uso e compartilhamento de REA}

Quando se trabalha com REA é preciso ter como base dois princípios: licenças de uso que permitam maior flexibilidade e uso legal de recursos didáticos; e abertura técnica, no sentido de utilizar formatos de recursos que sejam fáceis de abrir e modificar em qualquer software. Nesse sentido os REA devem primar pelo que chamamos de "interoperabilidade" técnica e legal para facilitar o seu uso e reuso (EDUCAÇÃO ABERTA, 2012, p. 4).

Para entender como funciona a produção dos REA, é preciso pensar em todo um "ciclo de vida" para esse recurso educacional. Na perspectiva de um educador, começa com uma tarefa que faz parte do cotidiano, ou seja, o desejo ou a necessidade de encontrar materiais para apoiá-lo em seu trabalho pedagógico. Esse ciclo de vida tem como etapas (op.cit.):

I. Encontrar: o primeiro passo é procurar recursos capazes de atender adequadamente à sua necessidade. Você pode utilizar ferramentas de busca na Internet ou ainda recorrer ao seu próprio material, como por exemplo: anotações de aula do ano anterior, projetos e atividades antigas, etc.

II. Criar: nessa etapa, você pode tanto criar seu recurso "do zero", como pode combinar os recursos que você encontrou para montar um novo recurso.

III. Adaptar: ao compor novos recursos, quase sempre será necessário fazer algumas adaptações no material que você encontrou para que ele se adeque ao seu contexto. Esse processo pode incluir correções, melhoramentos, contextualização e algumas vezes pode ser necessário refazer completamente o material. É importante lembrar-se de citar a autoria dos materiais originais que deram base para o que você acabou de adaptar. 
IV. Usar: finalmente você pode usar os REA na sala de aula, na Internet, em reuniões pedagógicas etc.

V. Compartilhar: uma vez finalizado o REA, você pode disponibilizá-lo à comunidade, de dentro e de fora da escola, que poderá reusá-lo e assim recomeçar o ciclo novamente.

Quanto mais comum e aberto for o formato, maior a chance de que você tenha um software para trabalhar com ele. Por sua vez em termos legais, se o material escolhido para usar com a turma contém uma licença restritiva ou "todos os direitos reservados" você não tem direito de modificá-lo (como por exemplo, cortar um trecho ou adicionar legendas) sem pedir permissão ao criador ou quem quer que seja que detêm os direitos. Se o material tiver uma licença mais aberta e permissiva, você pode trabalhar com o recurso sabendo exatamente quais direitos $\mathrm{o}$ autor da obra abriu mão para você e em quais condições. O uso e criação de REA ampliam, portanto, a liberdade de ensino e pode ajudar a repensar a "pirataria" e o "plágio" em sala de aula e nos trabalhos escolares.

As possibilidades de engajamento, produção, e não somente de "uso" (tanto de recursos para si quanto para os alunos) é um grande diferencial. [...] Muitas vezes sentimo-nos presos a materiais didáticos que não atendem nossas necessidades ou contextos de trabalho. REA é uma chamada para a participação -- para que você faça uso de recursos existentes, mas para que também contribua produzindo e modificando o que encontrar. Com REA, partimos do princípio de que muitos recursos de qualidade já existem e de que não é necessário sempre "reinventar a roda". [...] Podemos dizer que a comunidade que trabalha com REA reconhece que nada que criamos é perfeito para todos, e que tudo pode ser melhorado (EDUCAÇÃO ABERTA, 2012, p. 7).

\subsubsection{Tipos de licença Creative Commons}

Todas as licenças Creative Commons ${ }^{11}$ têm em comum muitas características importantes. Todas as licenças ajudam os criadores - que são chamados de licenciantes, se utilizam os instrumentos Creative Commons - a manter o seu direito de autor e os seus direitos conexos, ao mesmo tempo que permitem que outras pessoas copiem, distribuam e façam alguns usos do seu trabalho - pelo menos, para fins não comerciais. Todas as licenças Creative

\footnotetext{
${ }^{11} \mathrm{http} / / /$ creativecommons.org/licenses/
} 
Commons são aplicáveis em todo o mundo e duram o mesmo prazo que 0 direito de autor e/ou os direitos conexos aplicáveis (porque têm por base 0 direito de autor e/ou os direitos conexos). Estas características comuns constituem a forma de base. Os licenciantes podem depois optar por acrescentar autorizações adicionais, quando decidem de que forma pretendem que o seu trabalho possa vir a ser usado.

Um licenciante Creative Commons, responde a algumas perguntas simples para escolher a licença - primeiro, quero permitir o uso comercial ou não, e segundo, quero permitir trabalhos derivados ou não? Se o licenciante optar por permitir trabalhos derivados, pode exigir que todos aqueles que usam o seu trabalho - que são chamados licenciados - disponibilizem o novo trabalho ao abrigo dos mesmos termos da licença. Esta ideia é chamada de "Compartilhalgual" e este (se for escolhido) é um dos mecanismos que ajuda o conjunto de bens comuns digitais a crescer ao longo do tempo. A Compartilhalgual foi inspirada pela GNU General Public License, usada por muitos projetos de software livre e código aberto.

As licenças são as seguintes:

\begin{tabular}{|c|c|}
\hline (c) (1) & $\begin{array}{l}\text { Atribuição } \\
\text { CC BY }\end{array}$ \\
\hline & $\begin{array}{l}\text { Esta licença permite que outros distribuam, remixem, adaptem e } \\
\text { criem a partir do seu trabalho, mesmo para fins comerciais, desde } \\
\text { que Ihe atribuam o devido crédito pela criação original. É a licença } \\
\text { mais flexível de todas as licenças disponíveis. É recomendada } \\
\text { para maximizar a disseminação e uso dos materiais licenciados. }\end{array}$ \\
\hline (c) (†) (? & $\begin{array}{l}\text { Atribuição-Compartilhalgual } \\
\text { CC BY-SA }\end{array}$ \\
\hline & $\begin{array}{l}\text { Esta licença permite que outros remixem, adaptem e criem a partir } \\
\text { do seu trabalho, mesmo para fins comerciais, desde que Ihe } \\
\text { atribuam o devido crédito e que licenciem as novas criações sob } \\
\text { termos idênticos. Esta licença costuma ser comparada com as } \\
\text { licenças de software livre e de código aberto "copyleft". Todos os } \\
\text { trabalhos novos baseados no seu terão a mesma licença, portanto } \\
\text { quaisquer trabalhos derivados também permitirão o uso } \\
\text { comercial. Esta é a licença usada pela Wikipédia e é } \\
\text { recomendada para materiais que seriam beneficiados com a } \\
\text { incorporação de conteúdos da Wikipédia e de outros projetos com } \\
\text { licenciamento semelhante. }\end{array}$ \\
\hline (c) $(\oplus)$ & $\begin{array}{l}\text { Atribuição-SemDerivações } \\
\text { CC BY-ND }\end{array}$ \\
\hline
\end{tabular}




\begin{tabular}{|c|c|}
\hline & $\begin{array}{l}\text { Esta licença permite a redistribuição, comercial e não comercial, } \\
\text { desde que o trabalho seja distribuído inalterado e no seu todo, } \\
\text { com crédito atribuído a você. }\end{array}$ \\
\hline \multirow[t]{2}{*}{ (c) (†) \& } & $\begin{array}{l}\text { Atribuição-NãoComercial } \\
\text { CC BY-NC }\end{array}$ \\
\hline & $\begin{array}{l}\text { Esta licença permite que outros remixem, adaptem e criem a partir } \\
\text { do seu trabalho para fins não comerciais, e embora os novos } \\
\text { trabalhos tenham de Ihe atribuir o devido crédito e não possam } \\
\text { ser usados para fins comerciais, os usuários não têm de licenciar } \\
\text { esses trabalhos derivados sob os mesmos termos. }\end{array}$ \\
\hline \multirow[t]{2}{*}{ (c) (†) } & $\begin{array}{l}\text { Atribuição-NãoComercial-Compartilhalgual } \\
\text { CC BY-NC-SA }\end{array}$ \\
\hline & $\begin{array}{l}\text { Esta licença permite que outros remixem, adaptem e criem a partir } \\
\text { do seu trabalho para fins não comerciais, desde que atribuam a } \\
\text { você o devido crédito e que licenciem as novas criações sob } \\
\text { termos idênticos. }\end{array}$ \\
\hline \multirow[t]{2}{*}{ (c) } & $\begin{array}{l}\text { Atribuição-SemDerivações-SemDerivados } \\
\text { CC BY-NC-ND }\end{array}$ \\
\hline & $\begin{array}{l}\text { Esta é a mais restritiva das nossas seis licenças principais, só } \\
\text { permitindo que outros façam download dos seus trabalhos e os } \\
\text { compartilhem desde que atribuam crédito a você, mas sem que } \\
\text { possam alterá-los de nenhuma forma ou utilizá-los para fins } \\
\text { comerciais. }\end{array}$ \\
\hline
\end{tabular}

Tabela 1: Tipos de licenças Creative Commons

Sites de busca de REA e sugestões de repositórios de REA

$\checkmark$ http://www.google.com.br/advanced_search

$\checkmark$ http://search.creativecommons.org

$\checkmark$ http://www.flickr.com/search

$\checkmark$ http://www.jamendo.com

$\checkmark$ http://m3.ime.unicamp.br

$\checkmark$ http://www.poie.com.br/

$\checkmark$ http://reaparana.com.br/portal/repositorios/

$\checkmark$ http://www.portal.ufpr.br/rea.html

$\checkmark$ http://www.bibliotecadigital.unicamp.br/document/list.php?tid=600

$\checkmark$ http://repositorio.utfpr.edu.br/jspui/

$\checkmark$ http://www.rea.net.br/educarede/ 
$\checkmark$ http://portalsme.prefeitura.sp.gov.br/Projetos/memoria/Anonimo/CEDOC/ periodo/cole\%C3\%A7\%C3\%B5es.aspx

$\checkmark$ http://www.cetic.br/

$\checkmark$ http://canaltic.com/blog/?p=2040\#rea11

$\checkmark$ http://www.redalyc.org/articulo.oa?id=81830435006

$\checkmark$ http://educdigital.net.br/seminario/

$\checkmark$ http://www.cetic.br/publicacoes/indice/unesco/

$\checkmark$ http://repositorio.roca.utfpr.edu.br/jspui/

$\checkmark$ http://portaldoprofessor.mec.gov.br/index.html

$\checkmark$ http://www.dominiopublico.gov.br/

$\checkmark$ http://www.rea.net.br/site/

$\checkmark$ http://repositorio.roca.utfpr.edu.br/jspui/

$\checkmark$ https://periodicos.utfpr.edu.br/index.html

$\checkmark$ http://www.lume.ufrgs.br/

$\checkmark$ http://recursostic.educacion.es/bancoimagenes/web/

$\checkmark$ http://www.educacontic.es/

$\checkmark$ http://agrega2.red.es/

$\checkmark$ http://xn--educaoaberta-6bb9c.org/rea/ 


\title{
CAPÍTULO 3 - TRILHAR CAMINHOS, TECER COMPREENSÕES
}

Análise é o processo que conduz à explicitação da compreensão do fenômeno pelo pesquisador. O próprio pesquisador é o principal instrumento de trabalho, o centro não apenas da análise de dados, mas também a produção dos mesmos durante a entrevista (SZYMANSKI, ALMEIDA \& PRANDINI, 2004).

Ainda de acordo com Szymanski, Almeida \& Prandini (2004), antes mesmo de iniciar o procedimento de entrevista, o pesquisador já tem algum conhecimento e compreensão do problema, que provém, seja de seus referenciais teóricos, seja de suas experiências pessoais. Além disso, ele tem uma expectativa de resultados, que geralmente está explícita nos objetivos de pesquisa.

\begin{abstract}
A entrevista em contextos sociais está sujeita a várias intercorrências, não é asséptica, não está sob controle total do entrevistador. É importante manter o foco nos objetivos de seu trabalho para aproveitar os imprevistos, sem deixar que elas o tirem do eixo de seu problema de pesquisa (SZYMANSKI, ALMEIDA \& PRANDINI, 2004, p.73).
\end{abstract}

Assim, para essas autoras, diferentes pesquisadores podem construir categorias bem diferenciadas a partir de um mesmo conjunto de dados, pois essa construção depende da experiência pessoal, das teorias do seu conhecimento e das suas crenças e valores (SZYMANSKI, ALMEIDA \& PRANDINI, 2004).

Se considerarmos a perspectiva dialética desta pesquisa, a complexidade que envolve o tema, os diferentes espaços e tempos da investigação, nosso trabalho de organizar, analisar e interpretar as informações coletadas ao longo de quatro anos do curso e mais uma entrevista realizada com os egressos algum tempo após sua saída da Universidade, podemos concluir que essa pesquisa foi um enorme desafio. A quantidade de material produzido, a diversidade de formas de participação dos docentes em formação, bem como a complexidade de todo o processo nos levou a ter que priorizar a análise de alguns materiais em particular, dado o curto espaço de tempo disponível. 
Entretanto, a riqueza de todo o processo e dos materiais coletados nos mostrou que todo o trabalho realizado valeu bastante à pena, pois evidenciou nosso crescimento enquanto profissionais pesquisadores e docentes e, ao mesmo tempo, demonstrou a evolução dos educandos em sua jornada pessoal, acadêmica e profissional.

Assim, para realizar as análises e discussões acerca de todo o desenvolvimento do componente curricular Comunicação e Tecnologias da Informação no percurso da Turma 2, utilizamos algumas categorias definidas a priori e outras que surgiram no decorrer da pesquisa, conforme dissemos anteriormente.

A categorização concretiza a imersão do pesquisador nos dados e a sua forma particular de agrupá-los segundo a sua compreensão. Podemos chamar este momento de "explicitação de significados" (SZYMANSKI, ALMEIDA \& PRANDINI, 2004, p.73).

Também queremos deixar claro ao leitor que nossas análises e discussões são feitas a partir de escolhas ideológicas, epistemológicas, teóricas e políticas. Afinal, como dizem Szymanski, Almeida \& Prandini, "tanto o delineamento dos procedimentos de uma pesquisa, quanto a análise de dados dependem da opção teórico-metodológica do pesquisador" (2004, p. 64).

Bardin, sobre análise de dados qualitativos, bem como sobre análise de dados de entrevista diz que

Esta se apresenta como uma atividade de interpretação que consiste no desvelamento do oculto, do "não-aparente, o potencial de inédito (do não dito), retido por qualquer mensagem" (BARDIN, 1995 apud SZYMANSKI, ALMEIDA \& PRANDINI, 2004, p. 63).

Mergulhar na realidade desses sujeitos historicamente excluídos, fazer parte de seu cotidiano e de suas práticas educativas, buscar caminhos para resolver as contradições e a partir delas fazer emergir soluções que possibilitaram a construção de novas relações e novos conhecimentos nos auxiliaram no sentido de eleger categorias de análise capazes de nos levar além da busca de dados e informações. Sem a pretensão de querer superar os conflitos, mas atentos às questões centrais da pesquisa e ao caminho onde 
todo esse processo nos levava é que chegamos ao que o leitor encontrará a partir desta etapa do trabalho.

Tecer compreensões, no nosso entendimento, é compreender e interpretar o objeto de estudo, as relações estabelecidas, os conhecimentos construídos, os conflitos superados e também os que não o foram. Tecer compreensões também significa, neste contexto, encontrar pontos de intersecção, significa desvelar contradições, elucidar os sentidos ocultos. Trabalhamos, nas análises, com explicitação de significados ${ }^{12}$, com organização em contextos de significação que agora serão agrupados por categorias definidas a priori ou que surgiram no transcorrer dessa investigação.

Segundo Szymanski, Almeida \& Prandini (2004), a compreensão do fenômeno vai se modificando no decurso do processo de pesquisa e é paulatinamente aprofundada durante o trabalho de análise.

Para as autoras, "a análise de dados implica a compreensão da maneira como o fenômeno se insere no contexto do qual faz parte. Este inclui interrupções, clima emocional, imprevistos e a introdução de novos elementos" (SZYMANSKI, ALMEIDA \& PRANDINI, 2004, p. 72). E nossa pesquisa confirma essa declaração, pois sofreu inúmeros imprevistos, interrupções, elementos novos e ausência de elementos, enfim, é neste momento de interpretação dos fatos que conseguimos avaliar todos esses fatores e fazer uma leitura do processo.

Também foi nossa opção não separar análises e discussões, tecendo um rede entre as várias informações colhidas durante o percurso da Turma 2, suas entrevistas, outros momentos de diálogo e construção de conhecimento. Além disso, faz-se importante deixar claro que ao trazermos as respostas dos entrevistados nas análises e conclusões, nem sempre essas estarão exatamente com as palavras dos respondentes, pois no trabalho de análises qualitativas, às vezes, é preciso tornar a resposta compreensível ao leitor do relatório de pesquisa. No entanto, as respostas originais estão no Apêndice $D$, caso o leitor queira fazer essa leitura.

\footnotetext{
${ }^{12}$ BARDIN, L. Análise de conteúdo. Tradução de L.A. Antero e A. Pinheiro. Lisboa: Edições 70, 1995.
} 
Assim, ao entrevistarmos os egressos da Turma 2 da LEdoC-UnB, fizemos a opção por não utilizarmos os nomes reais dos entrevistados para manter o sigilo das respostas e para não constranger nenhum deles/delas. Os entrevistados são, então, tratados por nomes fictícios que escolhemos dos personagens de Guimarães Rosa na obra Grande Sertão Veredas por se tratar de uma obra que conta um pouco do contexto do sertão brasileiro. Entretanto, os nomes foram atribuídos aleatoriamente, sem nenhum critério de escolha.

Para fins didáticos dividimos as análises e resultados em três subcapítulos conforme a ordem cronológica dos acontecimentos, o que também reflete a evolução do crescimento individual e coletivo desses educadores.

Então, o primeiro subtítulo, Um sucinto diagnóstico sobre a Turma 2 e as Tecnologias Digitais, traz as informações mais relevantes coletadas nos primeiros contatos com essa Turma. Foi nesse momento que tivemos conhecimento da realidade desses sujeitos, de suas impressões sobre as Tecnologias de Informação e Comunicação, principalmente, computador e Internet, levantamos suas expectativas acerca da disciplina. Foi a partir desse diagnóstico que elaboramos os primeiros planejamentos e traçamos um caminho inicial a seguir com esse coletivo.

No segundo subtítulo, Compreensões de todo um percurso, desafios às transformações na Escola do Campo, tentamos relatar o que foi construído durante todo o curso, no decorrer das aulas em TE e do acompanhamento de TC. Nesse tópico trazemos informações sobre as observações realizadas e registradas no Diário de Campo. E também aqui, fizemos análises das Sínteses Coletivas elaboradas pela Turma ao final de cada aula em TE. Para fins didáticos, analisamos tais sínteses enquanto aprendizados, conflitos, contradições e dificuldades encontrados durante esse percurso. No entanto, preferimos não separar esses elementos porque seria um tanto complicado e repetitivo já que, em um mesmo fato ou informação pode conter conflitos e contradições, eles podem ter encontrado dificuldades e, ao mesmo tempo, isso pode ter gerado excelentes aprendizados.

Por fim, em Ensaios de práticas emancipatórias trazemos informações levantadas a partir de uma entrevista estruturada realizada por 
questionário online disponibilizado no Google Drive para que os, agora, egressos da Turma 2 respondessem sobre sua prática pedagógica posterior à conclusão do curso.

Seguem, então, essas compreensões que tivemos a partir da coleta de dados e informações realizada.

\subsection{Um sucinto diagnóstico sobre a Turma 2 e as Tecnologias Digitais}

Esse questionário foi aplicado no primeiro Tempo Escola da Turma 2 da LEdoC-UnB e foi respondido pelos 52 educadores do campo em formação à época. Isso aconteceu durante uma das aulas de Comunicação e Tecnologias da Informação e os sujeitos tiveram todo o tempo necessário para leitura e resposta.

De acordo com o questionário aplicado nas primeiras aulas do componente curricular e também com nossa observação, conforme informações que são apresentadas pelo colega de docência em sua investigação sobre a mesma turma ${ }^{13}$, cerca de $85 \%$ dos docentes em formação tiveram seu primeiro contato com computador nas aulas de CTI ou na LEdoC-UnB e o sentimento de receio em relação ao seu uso ficou claro neste momento.

Pela nossa observação, percebemos que não ousavam tocar a máquina, ligar, manusear autonomamente. Necessitavam de comandos passoa-passo para fazer atividades elementares como ligar e desligar os estabilizadores e os monitores. Fizeram longos processos de observação do teclado buscando encontrar ali a relação entre a escrita manuscrita do lápis, caneta, papel e a escrita digital ora impressa, ora em tela que seria gerada a partir dos toques no teclado.

Independentemente de faixa etária, estes $85 \%$ de docentes em formação da Turma 2 tinham as mesmas dificuldades em relação àquela nova tecnologia de comunicação que Ihes fora apresentada.

\footnotetext{
13 FERREIRA, Márcio. Comunicação e Tecnologias da Informação na formação de educadores para ampliação das perspectivas críticas dos sujeitos na Licenciatura em Educação do Campo da UnB. Tese de Doutorado. Programa de Pós-Graduação em Educação. Faculdade de Educação. Universidade de Brasília, 2014. Utilizamos as mesmas informações e fizemos as análises desses dados juntos.
} 
Havia, porém, um consenso único: o uso de computador e Internet seria indispensável para as atividades universitárias da LEdoC. Os 15\% restantes dos estudantes sabiam ligar, desligar, digitar vagarosamente pequenos textos, salvar arquivos de texto, utilizar navegadores de Internet.

De modo geral, os tópicos abaixo descrevem, sinteticamente, as condições dos docentes em formação em seus primeiros momentos educativos nas aulas de CTI:

$\checkmark$ para a maioria o primeiro contato com computador foi na LEdoC-UnB;

$\checkmark$ a maior parte dos estudantes não tinha conhecimentos básicos sobre computadores como ligar-desligar, digitação, utilidade e as possibilidades da informática;

$\checkmark$ com algumas exceções, os docentes em formação apresentavam uma noção equivocada de tecnologia, afirmando que o conceito de tecnologia descrevia somente artefatos da contemporaneidade como celulares, computadores de mesa, notebooks, máquinas da medicina, reatores nucleares, naves espaciais, etc. Não reconheciam, em sua maioria, os demais instrumentos de uso humano como tecnologia;

$\checkmark$ antes de começar a usar e discutir sobre as possibilidades da informática, pelo menos $43 \%$ dos educandos manifestavam a certeza de que computador não é coisa para o campo, tampouco para o sujeito do campo, ou seja, computador é desnecessário por não ter utilidade no campo;

$\checkmark$ a primeira grande tensão a ser superada foi o fato de que 32\% dos educandos recusavam-se a aprender como usar os equipamentos declarando estarem velhos demais e já terem vivido "bem" até o momento sem isto; também acharem ser perda de tempo esse aprendizado; não verem uso prático da máquina e do software; alegarem que computador afasta as pessoas e esfria as relações. 


\subsection{Compreensões de todo um percurso, desafios às transformações na Escola do Campo}

Como já foi relatado na metodologia, realizamos coleta de informações e fomos construindo conhecimentos durante todo o curso, a cada Tempo Escola e a cada Tempo Comunidade. Isso nos permitiu acompanhar a evolução e o desenvolvimento desses educadores em sua vida profissional, política e pessoal. Pudemos fazer os registros de momentos de dúvidas, de conflitos, de contradições, mas também de aprendizados e conquistas.

Relatar todo esse percurso daria uma coleção de livros, caso fôssemos fazer esse registro. Assim, para trazer ao leitor as informações mais relevantes tivemos que fazer difíceis escolhas, mas as fizemos na certeza de conseguir dar ao leitor uma visão ampliada e clara de toda riqueza dos processos aqui desencadeados e concretizados.

Aqui, como o leitor pode confirmar no Apêndice B - Relatos das aulas de CTI, para cada momento em TE em que trabalhamos a área de Comunicação e Tecnologias da Informação, trouxemos o registro dessas aulas com as seguintes informações: aula, conteúdo, objetivos, conceitos permeadores e síntese dos aprendizados. Também neste subcapítulo, trazemos as análises relativas às anotações constantes do diário de campo, que por sua vez, são resultantes da observação participante realizada durante todo o processo.

O esforço por essa organização foi no sentido de tornar a complexidade dos registros de nossos diálogos algo compreensível a outros leitores que não tenham convivido neste processo. Os registros e considerações aqui apresentados são produtos da interlocução, do diálogo, da observação e da coparticipação entre educadores e educandos na construção de um processo que foi ensino, aprendizagem, avaliação, memória e registro simultaneamente.

\subsubsection{Políticas públicas e exclusão digital no campo}

Não há dúvida de que os sujeitos do campo sofrem uma exclusão de oferta de computadores e Internet no campo. Esta exclusão só vem se associar a outras tantas como falta de acesso a uma Educação do Campo, falta de 
políticas de fortalecimento da agricultura familiar, abandono do Estado, e invasão do agronegócio ao campo brasileiro. Vale lembrar que os donos dos recursos do agronegócio têm computadores e Internet disponíveis, inclusive, tratores guiados remotamente por satélite. Esta é uma das reflexões feitas pelo coletivo de educadores em formação da Turma 2 da LEdoC. Para esses sujeitos, discutirmos essas questões relacionadas à exclusão digital e à exclusão social é falar sobre sua dura realidade, é retratar o que eles e elas vivenciam diuturnamente em suas comunidades.

Para eles, o campo e seus sujeitos também têm direito ao acesso à informação, pois não ter esse acesso afastará, cada vez mais, os sujeitos do campo da escolarização e do conhecimento.

Seus relatos são de imensas dificuldades em fazer coisas que para a maioria das pessoas da cidade são bastante simples, como escrever algumas frases no processador de texto, utilizar a Internet para fazer inscrições em concursos, vestibulares, editais, etc.

Sem o mesmo acesso à informação que as demais pessoas têm na cidade tudo fica mais difícil para que o agricultor familiar produza com eficiência e comercialize sua produção. Não ter e nem saber lidar com computador e Internet evita que o camponês tenha acesso à informação, crie novas formas de produzir, conheça outras culturas, acesse políticas públicas e serviços públicos diversos oferecidos por meio da Internet. Um exemplo disso é o próprio vestibular da LEdoC-UnB cuja inscrição é feita apenas pelo site do CESPE.

Os educadores em formação da Turma 2 construíram a consciência da necessidade de acesso à informação. Para eles, o sujeito do campo precisa ter acesso às informações locais e mundiais, precisa estudar, necessita procurar meios para produzir melhor no campo, necessita estar a par dos acontecimentos políticos do país. Eles sabem que para transformar sua realidade precisam ter conhecimento de mundo, sair do senso comum e participar mais ativamente na luta política por transformações sociais, por mudanças no sistema político, econômico e social do país. 
Uma reflexão interessante construída por esses sujeitos em um de nossos momentos de Tempo Escola foi a de que o acesso à informação também é uma necessidade do homem que faz com que ele seja parte, de verdade, do mundo, de suas mudanças, de seus destinos. Para eles, com a exclusão digital, cada vez mais algumas pessoas vão trabalhar com a cabeça e outros com os braços e isso é uma relação injusta... Ainda segundo a Turma 2, todos deveriam ter oportunidades iguais de aprenderem a usar os recursos que a humanidade construiu e poder escolher o quê e como fazer sua vida.

De um modo geral, as Tecnologias Digitais têm servido a uma minoria que são os pequenos burgueses (classe média alta) e os empresários (classe efetivamente dominante). No campo tais tecnologias ainda estão por chegar.

Para os educadores do campo em formação, aprender a usar as Tecnologias Digitais os coloca em um novo local para pensar o mundo. Daí Ihes surgem questionamentos como: "por que a informática existia o tempo todo e nós não sabíamos? Por que o mundo está mudando tanto e nós não estamos no barco dessas mudanças?"

Ainda nas discussões e diálogos sobre a exclusão digital e a exclusão social no campo e do campo, quando se vai pensar sobre a falta de computadores e Internet na escola e no campo, esses sujeitos acabam por pensar, primeiramente, em outras tantas carências e exclusões essenciais ligadas à necessidade de produzir para sobreviver, de ter saúde, de ter respeitada a cultura local, que o letramento digital acaba por ficar, quase sempre, em segundo plano em suas reivindicações.

E se vamos analisar os discursos desses educadores em formação, eles estão certos em questionar e lutar por mudanças na realidade de suas comunidades, de querer Educação do Campo de qualidade, de reivindicar processos educativos diferenciados conforme suas necessidades e suas especificidades. Justificamos essa afirmação com a concepção de Gramsci (BUTTIGIEG, 2003) de que educação significa muito mais que instrução escolar, que educação equivale, simplesmente, às operações fundamentais de hegemonia. Para Gramsci, as relações educacionais constituem o próprio núcleo da hegemonia, que qualquer análise da hegemonia necessariamente implica um cuidadoso estudo das atividades e das instituições educacionais e 
que nem as complexidades da hegemonia nem o significado da educação podem ser entendidos enquanto se pensar a educação exclusivamente em termos de "relações escolares" (BUTTIGIEG, 2003).

Mas o que seria uma operação de hegemonia? Para Gramsci (BUTTIGIEG, 2003), a civilização burguesa moderna se perpetua através dessas operações, isto é, das atividades e iniciativas de uma ampla rede de organizações culturais, movimentos políticos e instituições educacionais que difundem sua concepção de mundo e seus valores capilarmente pela sociedade. Assim, os grupos dominantes fazem as classes subalternas internalizarem sua ideologia e, como essas classes não têm uma visão de mundo coerente e homogênea que Ihes dê autonomia, que Ihes confira uma unidade de conjunto, de coletivo, isso os enfraquece e os faz se subordinarem intelectual, econômica e político-ideologicamente (idem).

Os educadores da Turma 2 já não estão mais no senso comum, já conseguem refletir que um dos sintomas de que saber usar computador e Internet é um dentre os muitos elementos de poder na sociedade contemporânea que aparece dentro do próprio grupo, pois a maior parte dos educandos não sabe lidar com esses equipamentos e o Estado não parece estar muito interessado em Ihes dar essa oportunidade. Refletem que, para o Estado, talvez seja interessante mantê-los ignorantes sobre essas novas formas de agir e participar da sociedade. Ou seja, o Estado não facilita seu acesso e apropriação destes recursos tecnológicos porque 0 acesso às informações pode fazê-los ficarem mais críticos e atentos aos movimentos da hegemonia.

E chegamos à conclusão que eles podem ter razão, pois exemplos disso são as políticas públicas voltadas para o campo. Algumas delas, após muita luta dos movimentos sociais do campo, foram constituídas, mas nem sempre implementadas como deveriam. As licenciaturas em Educação do Campo mesmo passam por inúmeras dificuldades que quase as impossibilitam de terem continuidade: falta de corpo docente especializado e concursado; ausência de recursos financeiros para 0 acesso e a permanência dos educandos na universidade durante o Tempo Escola; atrasos constantes nas bolsas referentes a alimentação e estadia desses sujeitos na universidade; 
carência de laboratórios de informática suficientes e com conectividade para pesquisa e estudo; enfim, são criadas as políticas, mas para elas saírem do papel há que se travar uma luta por dia com os diversos entes políticos.

Outro exemplo de política pública voltada para o campo e que não se concretizou com êxito foi o programa Territórios Digitais. Esse programa previa a instalação de telecentros digitais (também chamados Casas Digitais) em comunidades campesinas contendo: 11 computadores, impressora, projetor digital, mobiliário para este equipamento e Internet com conexão via satélite. $O$ que a comunidade precisava disponibilizar para receber a Casa Digital era um espaço adequado (com metragem específica e instalação elétrica correta) que fosse cuidado e gerenciado por alguma associação ou cooperativa da comunidade que se responsabilizasse por esses equipamentos. $E$ aos estados e municípios caberia a contrapartida de promover a formação dos gestores dessas Casas. Infelizmente, além dos equipamentos chegarem às comunidades faltando os projetores, a Internet oferecida era de péssima qualidade (baixa velocidade de download e upload) e as relações com os estados e municípios nem sempre foram os mais amistosos, às vezes, até inviabilizando o envio do equipamento e a formação dos gestores para manutenção dos equipamentos.

Esse relato é possível porque fomos gestores de uma Casa Digital instalada na própria Universidade de Brasília e ficamos responsáveis por fazer a formação desses gestores. Realizamos a formação, no entanto, passamos por inúmeros problemas de ordens diversas.

Também no âmbito da Escola do Campo, as informações sobre as políticas não chegam aos educadores. Um exemplo disso é o nível de exclusão sentido pelos educandos em relação à existência do Portal do Professor, uma instituição do Governo Federal feita no sentido de disponibilizar recursos digitais como e-books, sugestões de estratégias didáticas inovadoras, vídeos, etc. Os educadores em formação disseram não saber da existência de tal Portal, bem como do Portal Domínio Público. E será que esses Portais atendem à Educação do Campo em suas peculiaridades ou são mais um conjunto de instrumentos ideológicos para fortalecer o afastamento do homem do trabalho, da natureza e de sua necessidade de ser um ser de relações? 
Como dizem os próprios educadores em formação, não é por acaso que poucos são os sujeitos do campo que conseguem entrar nas universidades, mesmo as que têm licenciatura em Educação do Campo: o sistema vai colocando uma série de dificuldades para o pobre campesino acessar educação com a intenção de deixar de fora da educação de qualidade quem já vem sendo excluído da educação há muito tempo, desde a Educação Básica.

Assim se reforça cada vez mais a ideia de que o trabalhador é uma coisa, uma mercadoria a mais nesse sistema. $E$ quanto mais sem educação o trabalhador for, mais incapaz de ser dono de força de trabalho ele será. E venderá essa força de trabalho ao preço que o patrão quiser pagar, reforçando e alimentando o poder do capital.

Uma informação que julgamos ser de grande importância nesse contexto é que no último TE da Turma 2 os educadores em formação em quase sua totalidade (digamos que $90 \%$ ), já tinham adquirido seu próprio notebook, ou seja, a partir das aulas e do aprendizado construído eles foram percebendo a importância das Tecnologias Digitais para seu desenvolvimento pessoal e profissional e colocaram a aquisição de um computador pessoal em sua lista de prioridades.

\subsubsection{Instrumentalização, formação e interdisciplinaridade}

A Oficina de Informática, nome inicial do componente curricular que ora investigamos e, mais tarde, denominado Comunicação e Tecnologias de Informação, tinha como objetivo principal instrumentalizar os estudantes da LEdoC-UnB para o uso do computador e da Internet no curso. Entretanto, a partir de discussões intensivas nas reuniões de planejamento da Licenciatura, pudemos mostrar ao corpo docente do curso a necessidade de ampliação dos objetivos da área de conhecimento incluindo, para além da instrumentalização desses sujeitos, sua formação para a utilização de computador, Internet e outras Tecnologias Digitais nos processos educativos.

A partir das aulas em TE e das discussões realizadas em TC os educadores em formação relataram que puderam aprender novas técnicas de utilização de computador e Internet para fazer as coisas necessárias ao 
desenvolvimento da vida e, segundo esses sujeitos, a construção do conhecimento técnico é necessária como forma de reduzir a força da opressão, da dominação, a separação entre ricos e pobres. Ainda de acordo com esses sujeitos, ter técnica é importante. Não ter acesso à técnica é mais uma faceta da negação de seus direitos.

Para esses educadores do campo, entender os meandros técnicos das Tecnologias Digitais é também entender o que a elite do país e do mundo sabe, o que ela domina, o que ela produz e que muitas vezes serve ao restante da população. E entender isso, pode auxiliá-los em ações contra-hegemônicas. Essas e outras tecnologias podem ser apropriadas pelos coletivos do campo e utilizadas para outras lutas contra a opressão.

O processo de construção desses conhecimentos não foi fácil para esses sujeitos acostumados a colocar as mãos na enxada e no facão para plantar e que de um momento para outro passam a ter que desenvolver a leveza e a suavidade nas mãos para movimentar o mouse. O que a princípio era doloroso e lento vai se tornando, pela prática, produtivo e os ajuda a resolver coisas importantes na LEdoC-UnB, na escola do campo e em suas nossas comunidades.

Aplicativos e programas, aos poucos vão sendo apropriados e ao mesmo tempo passam a ensinar a esses sujeitos, conforme seus relatos. $O$ corretor ortográfico do editor de texto, por exemplo, os ajudou a melhorar sua escrita, segundo a síntese de uma aula.

As discussões sobre uso das Tecnologias Digitais os auxiliaram a planejar melhor suas aulas, seja na realização de pesquisa de materiais, textos, vídeos, seja na confecção de seus próprios textos e materiais. De acordo com esses educadores do campo, quanto mais avançavam em CTI, mais aprendiam a lidar com o computador para outras coisas e mais construíam conhecimentos que os tornam capazes de entender melhor 0 mundo, com olhares mais críticos e atentos.

Novas apropriações iam se dando e utilizar apenas softwares proprietários já não satisfaziam a esses sujeitos. Se existe software livre, tem Linux, é preciso sair desse sistema da classe dominante e criar os próprios 
softwares. Assim, os educadores do campo da LEdoC foram se apropriando das Tecnologias Digitais e se empoderando diante delas. Passaram a utilizar computador e Internet para elaborar os trabalhos dos outros componentes curriculares, a fazer material para apresentar suas pesquisas e ações de Tempo Comunidade, a usar celular, smartphone, a criar perfis em redes sociais. E ao se empoderarem e utilizarem esses meios de comunicação, começaram a espalhar sua voz, suas reivindicações e de seus coletivos, passaram a tomar frente em outros coletivos e empreender ações de cooperação e de formação de outros sujeitos. Assim, as Tecnologias Digitais iam Ihes mostrando o quanto eles eram importantes para suas comunidades e escolas e iam Ihes servindo de suporte comunicacional para compartilharem e construírem novos coletivos com os mesmos objetivos contra-hegemônicos. A universidade tem importante papel nesse processo. Para Molina,

Como parte integrante das relações de poder na sociedade, a universidade pública é um aparelho tradicional de hegemonia, no interior do qual se apresenta uma diversidade de projetos em disputa pela direção intelectual e moral da sociedade. Sua autonomia relativa faz com que esse espaço se configure como um contraditório especialmente relevante para uma reflexão sobre a materialidade práxica dos projetos de sociedade que nela se formam e se expandem para o conjunto da sociedade civil. (MOLINA, 2014, p. 273)

Em suas práticas pedagógicas, mais e mais era possível notar mudanças substanciais em relação à criticidade para seleção de textos e materiais, criatividade na elaboração de novas atividades e novos estabelecimentos de relações com educadores do campo de outras comunidades e escolas.

As contradições existiam e ficavam cada vez mais evidentes para esses sujeitos. Por exemplo, há Blogs que vendem produtos, que trocam coisas, que oferecem consultoria em vários ramos, que ensinam, que guardam histórias. Há Blogs que defendem o capital e há blogs que o condenam. As possibilidades eram muitas...

Além disso, os Blogs passaram a ser espaços de comunicação entre comunidades campesinas e podiam ser úteis para trocas de experiências em relação a práticas agroecológicas e à pecuária, ou até mesmo como forma de pensar, discutir e fortalecer as lutas sociais. 
Para esses sujeitos, em determinado momento da formação, o Blog passou a ser considerado um instrumento de produção e divulgação de bens intelectuais, de bens culturais. De fato, o Blog é uma ferramenta digital de expressão que pode servir para produzir e divulgar ideias e ideologias. Esse instrumento de expressão pode servir (e tem servido prioritariamente) à classe dominante, mas também é possível que a classe trabalhadora passe usá-lo para o trabalho e a educação. Como contraponto, o acesso à Internet nas comunidades é um problema central que os exclui, mais uma vez, de uma oportunidade potencialmente rica. Assim relatam esses educadores do campo.

A discussão sobre as redes sociais como ferramentas de criação de coletivos humanos foi iniciada com estranheza, mas com o decorrer das aulas o grupo foi compreendendo que é possível se encontrarem e expressarem suas opiniões pelo Facebook, por exemplo, seguindo ou sendo seguidos pelos companheiros que estão do mesmo lado na luta social. Alguns desses educadores já têm perfis do Facebook onde postam exclusivamente denúncias e ações dos movimentos sociais do campo em suas comunidades.

Por outro lado, as redes sociais já estão bastante contaminadas pelos princípios do capitalismo no sentido de que tudo é para venda, tudo é para obtenção de lucro, que o mundo e as pessoas existem para comprar. Ainda são raros os perfis de pessoas que pensem de um modo diferente, discutindo as injustiças e as desigualdades sociais, relatam os sujeitos desta pesquisa.

Saberem das possibilidades de mudanças econômicas advindas do uso de Blogs, websites, redes de relacionamento, e-governo Ihes permitiu entender que poderiam mudar sua relação com a natureza e com os demais sujeitos da comunidade, produzindo melhor, organizando-se melhor, criando consciência de seu papel social no mundo, pois sabem que é a partir do momento em que pensam suas necessidades de sobrevivência, que passam a entender melhor porque existem as leis, a política, o Estado: na maior parte das vezes é para controlar quem produz o quê para quem.

Os Ambientes Virtuais de Aprendizagem permitem a disponibilização e a utilização de recursos diversos em um mesmo espaço. Ali, de acordo com os sujeitos pesquisados, é possível guardar planejamentos de aulas, materiais diversos como textos, listas de exercícios, avaliações, apresentações, vídeos, 
entre outros, principalmente conteúdos abertos. Também no AVA é possível se promover um espaço complementar de discussões sobre os temas estudados, isso quando na comunidade existem computadores e Internet para que os educandos acessem o AVA fora do horário das aulas. Seria de grande valia para os educadores do campo que em todas as casas dos moradores do campo houvesse computador e Internet, os espaços educativos e de interações seriam enormemente ampliados.

Os Recursos Educacionais Abertos possibilitam aos movimentos sociais e aos sujeitos do campo a utilização e a produção desses materiais sem que esses atores sejam excluídos do acesso e produção de conhecimento, enquanto os conteúdos proprietários apenas geram mais valia para os grandes empresários das Tecnologias Digitais.

Essa produção e compartilhamento de REA poderão introduzir novos formatos de materiais didáticos e pedagógicos, tirando o foco do livro didático e dos materiais de sistemas de ensino, que em sua maioria só visam o lucro, deixando a desejar em relação à sua qualidade. Mas para as Escolas do Campo os REA passam a ser uma ótima possibilidade de produzir material contextualizado para as aulas. Acrescente-se a isso o fato de inaugurar a produção de materiais didáticos pelos próprios educadores e educandos das comunidades em que as escolas estão inseridas.

Outro ponto em que os sujeitos pesquisados tocam, quando dos nossos diálogos pedagógicos, é na possibilidade de que esses recursos produzidos pelos próprios sujeitos da relação educativa ajudem a promover a interdisciplinaridade e propiciem aulas mais interessantes e criativas, facilitando o aprendizado dos educandos do campo.

\subsubsection{Tecnologias Digitais e poder}

Refletir sobre o papel social dos meios de comunicação é muito mais que fazer uma lista dos recursos de comunicação existentes em uma sociedade ou comunidade. É entender que relações de poder moram nas formas e intencionalidades da invenção e desenvolvimento de cada um desses recursos. Se não discutimos isso de modo crítico acabamos por não entender que tal análise é muito mais do que possa parecer em um primeiro olhar: há 
intenções de manter e fortalecer a dominação de uma classe pela outra; de sustentar o modo de produção onde o homem está cada vez mais distante de entender seu processo de trabalho e produção; afastar o trabalhador do aprendizado sobre como dominar técnicas de desenvolvimento de tecnologias de informação, pois isso é fonte de poder; aumentar o lucro das empresas que criam e exploram os meios de comunicação em função de que a maior parte dos sujeitos não entende seus processos de produção e suas intencionalidades subjacentes de fortalecimento da dominação.

Quanto mais modernos os meios de comunicação (celular, computador, Internet, etc.), mais eles contribuem para garantir o aumento de lucro dos donos dos meios de produção. Afinal, a função dos meios de comunicação digitais, em grande parte, é maximizar a produção, aumentando lucros, reduzindo custos, dando ênfase na ideia da máquina como fonte de trabalho mais eficiente que o homem e usando isso como justificativa para pagar cada vez menos pela força de trabalho dos sujeitos.

Durante o curso, os sujeitos pesquisados relataram que foi importante compreender que as Tecnologias Digitais facilitam a comunicação humana e favorecem 0 acesso à informação e que o computador constitui-se um patrimônio intelectual da sociedade. Se observarmos as respostas ao questionário diagnóstico respondido pelos sujeitos da pesquisa, notaremos que para boa parte deles o computador não tinha utilidade e nem importância para os sujeitos do campo no início do curso.

Para esses sujeitos, com as novas tecnologias o homem reduz o tempo de produção dos bens e aumenta a lucratividade no mesmo tempo. Com isso, o patrão conseguiu novas formas de sugar mais e mais do potencial de trabalho do ser humano e da máquina que é produzida também pelo ser humano. É o uso do trabalho do ser humano no sentido de gerar mais desvalorização do trabalho do próprio ser humano.

Já a Internet tem várias faces, segundo esses educadores em formação: umas positivas, outras negativas. No seio desta discussão também se encontram contradições. Dentre os aspectos positivos, em relação a Internet e educação, há a questão da velocidade e da abrangência. Com a Internet, as buscas de textos, vídeos, imagens e outras formas de expressão são bastante 
rápidas e diferentes das formas tradicionais de buscas como em uma biblioteca física, por exemplo. Há uma grande quantidade de informações em todas as áreas de conhecimento circulantes na Internet. É possível encontrar informações sobre tudo. Por outro lado, é preciso estabelecer critérios e seguilos ao fazer a seleção desses materiais pesquisados, existem muitos recursos bons, mas também existem materiais sem nenhuma comprovação e idoneidade no seu conteúdo. Aprender a selecionar páginas e materiais é uma tarefa difícil, dizem os educadores do campo em formação.

Outro fator importante diz respeito à privacidade na Rede, há que se ter muito cuidado com as informações pessoais já que há pessoas especializadas na utilização fraudulenta das informações inseridas na Internet. Além disso, existe a possibilidade de conteúdos perigosos serem divulgados com a atribuição criminosa da autoria a uma pessoa que de fato não produziu este material. Nas Redes Sociais, principalmente, aqueles que criam um perfil passam a estar expostos em escala planetária e é necessário muito cuidado com o que se posta, o que se replica, o que se diz.

A Internet é um ambiente de acesso à informação, mas também é um espaço de interações diversas que buscam refletir e reproduzir as relações da vida não virtual. A Internet tem alto poder de propaganda (positiva ou negativa), de venda, de expressão ideológica. Desse modo, a própria Internet tem que ser vista como um equipamento que fortalece processos de adoração da mercadoria. A própria Internet é uma mercadoria. Há, inclusive, jogos em que os jogadores precisam comprar dinheiro virtual com dinheiro real.

Para os educadores em formação, a produção e o compartilhamento de Recursos Educacionais Abertos pelos sujeitos e coletivos do campo podem promover o fortalecimento do movimento da Educação do Campo e também o movimento por um projeto societário voltado para a classe trabalhadora, gerando materiais contextualizados e, ao mesmo tempo, politizados. Isso depende, segundo sua concepção, da vontade e da mobilização de educadores e educandos do campo. 


\subsubsection{Desvantagens do uso do computador e da Internet}

Conforme relato dos educadores em formação, havia muito preconceito em relação à Internet no grupo porque ela é vista no campo como desagregadora, como fonte de coisas ruins, de pornografia, de propaganda, como algo que separa os pais e os filhos, onde os filhos ficam o tempo todo no computador e não dão mais atenção para as brincadeiras de correr, pegar, com as coisas da natureza.

De fato, a Internet tem pornografia, jogos sem fins educativos, redes sociais sem caráter produtivo e está assentada sobre um mercado muito forte que quer fazer propaganda e difundir o consumo pelo consumo. Entretanto, há meios de se utilizar a Internet e evitar tais elementos nocivos às boas práticas, seja por meio de antivírus, seja por bloqueadores de conteúdos, ou até mesmo, fazendo o acompanhamento sistemático dos usos pelo filho, ou pelos estudantes de uma turma.

De acordo com os sujeitos pesquisados, outra desvantagem do uso constante da Internet é que as pessoas passam a escrever errado pela supressão (tão comuns na comunicação pela Internet) de palavras e letras, se esquecendo como é a escrita correta das palavras.

O uso da Rede Mundial de Computadores pode gerar o isolamento social, segundo os educadores do campo em formação, quando as pessoas passam mais tempo consigo mesmas em casa e evitam se relacionar com as pessoas fora do mundo virtual. $O$ excesso de imersão dos sujeitos no ciberespaço pode levar à substituição das relações interpessoais físicas apenas pelas relações na Internet. Isso pode empobrecer relações importantes como com amigos, familiares, colegas de escola, etc. No entanto, esse isolamento pode ser relativo, já que muitas pessoas, por serem tímidas, conseguem se relacionar melhor pela Internet, através das Redes Sociais, do que pessoal e fisicamente. Nesse caso, a Rede proporciona melhores interações a essas pessoas.

A Internet pode causar males à saúde como danos à coluna, lesão por esforço repetitivo, vista cansada, etc., mas tudo depende do tempo e intensidade do uso. 
A partir das percepções dos sujeitos pesquisados, a Internet sedimenta segregações onde aquele que não tem acesso fica prejudicado no perverso mundo da concorrência entre indivíduos. Logo, não ter acesso fomenta a diferença de oportunidades aumentando o fosso entre as classes.

Um fator importante a ser destacado, conforme os educadores em formação, é a questão da dependência que o uso da Internet pode causar. Dependência dos usuários quanto ao conteúdo, pois passam a procurar informações somente neste meio e a dependência patológica que alguns acabam desenvolvendo e que pode ser comparada à dependência química. Já existem até clínicas especializadas na dependência tecnológica.

Ainda dentre os aspectos negativos do uso de Internet, conforme os educadores em formação relataram, há outros a elencar: nem toda informação procede de fonte segura; dificuldade de selecionar informação pertinente porque há muito lixo; as relações profissionais acabam sendo contaminadas pelo imediatismo próprio do meio; relações pessoais não são aprofundadas pela frieza e necessidade de pressa típica desse modo de comunicação; nem sempre há como se certificar da correção das informações; invasão de privacidade pelo uso indevido de informações pessoais; espaço que também serve a crimes e abusos; presença de pornografia infantil e adulta com acesso irrestrito; constante criação e disseminação de vírus digitais e spams (propagandas); precarização da cultura escrita; jogos e entretenimentos violentos e de cunho discriminatório ocupam as cabeças de crianças e adolescentes atrapalhando seus estudos, etc.

Os males das tecnologias, de um modo geral, ainda podem passar pela precarização do trabalho humano; desemprego; geração de lixo tóxico; subvalorização da força de trabalho do homem; fortalecimento das forças de dominação; está nas mãos de poucos a capacidade de produzir tecnologias mais avançadas; o trabalhador não tem acesso às tecnologias mais avançadas ficando somente com as tecnologias que já tiveram seu poder de ação bastante desgastado e já estão sendo substituídas por tecnologias mais eficientes; o homem do campo que trabalha com agricultura familiar só fica com as tecnologias que já estão ultrapassadas e não tem acesso a produtos de ponta; 
algumas tecnologias degradam muito o meio ambiente e podem trazer riscos à saúde, como os defensivos agrícolas e sementes transgênicas.

Segundo os pesquisados, outro aspecto detectado na discussão sobre a Internet e seu papel na educação diz respeito à grande quantidade de informações disponíveis e que vão tendo sua quantidade exponencialmente aumentada. Isso pode gerar estresse cognitivo, pois ainda não somos capazes de processar toda essa quantidade de informações. A Internet é uma tecnologia para ser utilizada a serviço do ser humano e não deve ser escravizadora.

\subsection{Ensaios de práticas emancipatórias}

Ao falarmos de práticas emancipatórias estamos falando em práticas pedagógicas que são contrárias àquelas utilizadas e preconizadas pelo capital, sistema que detém a hegemonia em nosso país. Desse modo, falar de prática emancipatória é falar de contra-hegemonia.

Neste tópico trazemos informações levantadas a partir de uma entrevista estruturada realizada por questionário online disponibilizado no Google Drive para que os, agora, egressos da Turma 2 respondessem sobre sua prática pedagógica posterior à conclusão do curso. A partir das respostas pudemos elaborar gráficos que nos auxiliaram no sentido de mostrar ao leitor a realidade atual desses egressos. Como foi dito anteriormente, infelizmente não foi possível que todos os egressos da Turma 2 respondessem ao questionário por vários fatores: mudança de endereço, mudança de e-mail, falta de conectividade na comunidade dos egressos, dentre outros. Entretanto, acreditamos que a quantidade de respondentes foi significativa para a pesquisa, principalmente porque abrangeu egressos das várias localidades atendidas na Turma 2: Distrito Federal, Goiás, Mato Grosso, Mato Grosso do Sul e Minas Gerais tiveram representação nessa atividade.

Um ponto a se ressaltar aqui é que só foi possível realizar a entrevista por meio eletrônico pelas habilidades e competências construídas pelos educadores durante o curso, já que era um questionário digital online. 


\subsubsection{Escolas do Campo e formação docente}

Pelo histórico trazido pelos docentes em formação na Licenciatura em Educação do Campo, temos percebido que na maioria das escolas do campo ainda existem muitos professores do Ensino Fundamental e Médio com formação em nível de Ensino Médio, apesar da LDB 9394/1996 preconizar que a partir de 2006 nenhuma escola da educação básica deveria ter professores sem formação de nível superior, e embora poucas sejam as escolas de Ensino Médio no campo.

Por exemplo, quando perguntados se atuavam como docentes em uma escola do campo quando do ingresso na Licenciatura em Educação do Campo da UnB, $54,5 \%$ dos entrevistados disseram que sim, ou seja, já atuavam como docentes em alguma escola do campo. Outros $27,3 \%$ disseram que, apesar de atuarem em escola do campo, não atuavam diretamente na docência, isto é, trabalhavam na área administrativa, como servidores da limpeza, portaria, cantina ou biblioteca. E os $18,2 \%$ restantes disseram não atuar em escola do campo ou docência naquele período, conforme Gráfico 1.

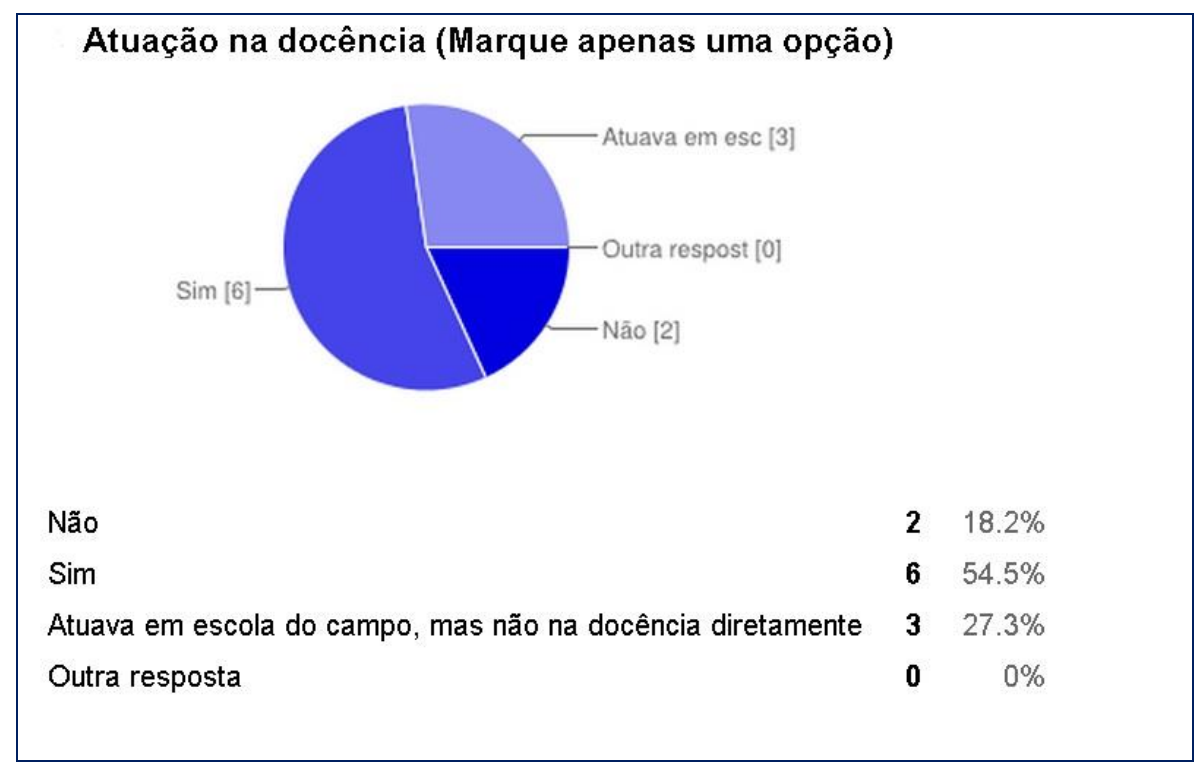

Gráfico 1: Atuação na docência antes da LEdoC

As políticas de formação de professores no Brasil foram sempre muito omissas em relação aos docentes das escolas rurais. Durante a maior parte da história do país, as escolas do campo foram relegadas a segundo plano e como dissemos anteriormente, serviam apenas para alfabetizar o filho do 
trabalhador rural o suficiente para que ele realizasse seu trabalho a contento. Desse modo, para quê haveria necessidade de ter professores bem formados e bem qualificados nas escolas rurais?

Nos últimos doze anos essas políticas têm mudado e juntamente com outras políticas públicas, o campo brasileiro tem sido inserido na agenda do governo que, na medida das possibilidades, tem atendido às demandas dessa população historicamente excluída. Ainda há muito que se pensar e fazer, mas aos poucos o campo vem se fazendo ouvir. E é aí que entra o papel dos educadores e educadoras do campo, na formação de massa crítica nas escolas do campo, de modo que, a cada dia, mais e mais comunidades se façam ouvir e tenham atendidas suas reivindicações, seja enquanto movimento social, seja enquanto entidade de classe ou sindicato do campo, ou sociedade civil organizada.

Como vimos dizendo desde o início deste estudo, a partir da junção das forças desses movimentos é que se passará a forjar um novo projeto societário que dê conta do campo, enquanto lócus de vida e produção, mas que também provoque transformações radicais no nosso país para nos livrarmos do jugo do modo de produção capitalista.

É, também, aí que entra o papel das Licenciaturas em Educação do Campo, as Pedagogias da Terra, os cursos do PRONERA e tantas outras políticas de formação do povo campesino. Papel esse de formação profissional, mas também de formação política e crítica.

Já, ao serem questionados, os entrevistados, se estão atuando ou atuaram como docentes após concluírem a Licenciatura, 54,5\% disseram que atuam na docência em escolas do campo após a conclusão do curso, mesma quantidade de antes da formação; enquanto 18,2\% afirmaram atuar em escola do campo, mas não na diretamente na docência e 9,1\% que não estavam atuando na docência e nem em escola do campo, como mostra o Gráfico 2. Os demais $18,2 \%$ disseram que estão aguardando serem chamados e que a demora deve-se ao favorecimento de alguns pelo gestor da escola. 


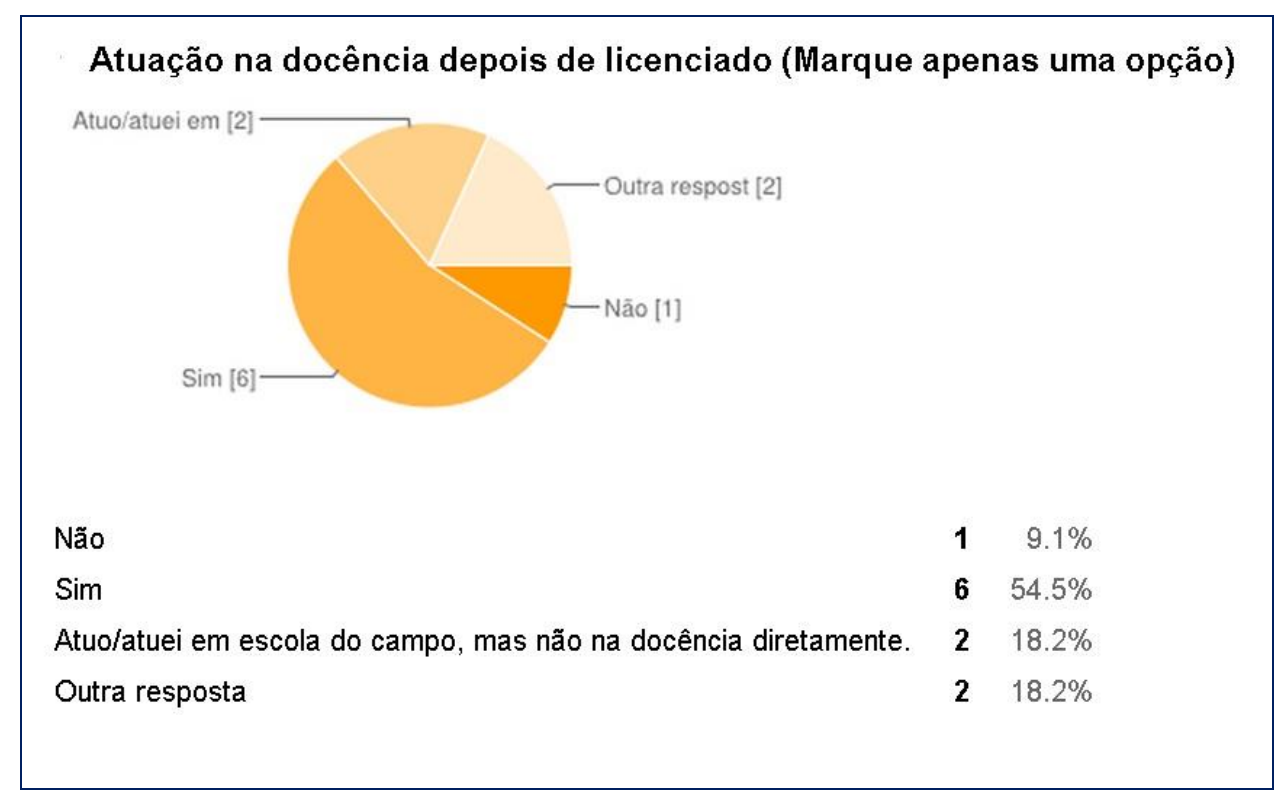

Gráfico 2: Atuação na docência depois da LEdoC

Isso nos leva a outro conflito no âmbito da Educação do Campo e relação à educação: a ausência de realização de concursos sérios, com lisura, para contratação de profissionais de educação, e também de outras áreas, nos municípios e nos estados. Esse fato reflete o quanto o Estado brasileiro está atrasado no estabelecimento e controle das ações dos agentes públicos de um modo geral. Os governos locais continuam atendendo a interesses particulares de grandes empresários, latifundiários, políticos de alto escalão.

Muitos dos egressos da LEdoC perderam seus empregos porque os secretários municipais ficaram receosos que os docentes recém formados numa perspectiva crítica pudessem Ihes trazer complicações. Melhor demiti-los e contratar novos professores leigos que, em sua necessidade e ingenuidade aceitam cumprir o papel que o Estado obriga por uns poucos trocados e total proletarização e precarização do trabalho docente: turmas multisseriadas lotadas para diminuir o número de professores a remunerar; jornada exaustiva; excesso de trabalho burocrático a executar, além das tarefas docentes; nas escolas do campo os professores, em muitas das vezes, desempenham várias funções além da docência como, servidores da limpeza, merendeiras, entre outras; falta de material didático; salas de aula em condições precárias. Enfim, condições às quais os egressos de uma Licenciatura em Educação do Campo ou Pedagogia da Terra, por serem mais questionadores, dificilmente aceitariam sem problematizar. 


\subsubsection{Tecnologias Digitais e coordenação pedagógica}

A coordenação pedagógica é, ou deveria ser, mais um momento de formação na vida profissional de um educador, pois é nesse momento que ele pesquisa metodologias, práticas, atividades, conteúdos, materiais, recursos de um modo geral. É também na coordenação pedagógica que o educador conversa com seus pares, traça estratégias de ação, realiza diagnósticos da situação das turmas com as quais se relaciona, pede orientação para coordenadores, gestores, etc.

Infelizmente a tradição na maior parte das escolas brasileiras é outra. Costuma-se prescindir da coordenação pedagógica em detrimento de inúmeras outras demandas particulares ou que a própria escola exige. Além disso, são pouquíssimos os estados e municípios com tempo para coordenação adequado, geralmente são 4h semanais para uma jornada de $20 \mathrm{~h}$.

\subsubsection{Coordenação Pedagógica}

O caráter coletivo da coordenação pedagógica pode ser destacado pelo prefixo co da palavra coordenação que significa estar próximo, junto aos pares, representa a possibilidade de uma co-ordenação. Para Anastasiou, coordenação "(...) é o ato de conjugar, concatenar um conjunto de elementos ou atividades, ou a gestão de determinado projeto ou setor, sendo responsável pelo andamento, pelo processo" (ANASTASIOU, 2009, p. 223).

A coordenação pedagógica, na perspectiva da ordenação, constitui-se como espaço-tempo de trabalho fragmentado, alienado e alienante, com foco no emergencial e no procedimental levando à burocratização da função, ou seja, é lugar de tradução das exigências institucionais como instrumento de adaptações. Essa concepção gera o trabalho individualizado que dificulta a ação dos(as) coordenadores(as) e, ao mesmo tempo, produz a desresponsabilização dos mesmos(as) pela ausência de organização do trabalho pedagógico coletivo. A ação dos(as) coordenadores(as) acaba sendo solitária (GDF, 2014, p.22).

$\mathrm{Na}$ perspectiva da co-ordenação, o trabalho pauta-se na reflexão da prática sem desprezo aos procedimentos, na ação coletiva e emancipadora, cujo foco está no processual levando à construção de trabalho colaborativo, 
constituindo-se como espaço-tempo de possibilidades e de liderança pedagógica democrática. A ação dos(as) coordenadores(as) é reflexiva e impulsionadora, propositiva e de ação solidária. Esta é a concepção de coordenação almejada por professores que buscam o desenvolvimento da escola e da educação de qualidade social (FERNANDES, 2012).

Os espaços-tempos de coordenação pedagógica oportunizam reflexões sobre a organização do trabalho pedagógico da escola, analisando se desenvolvem a coordenação na perspectiva da ordenação ou da co-ordenação. Assim, a coordenação pedagógica precisa consolidar-se como espaço-tempo de reflexões geradas pelos processos formativos e de autoformação, contemplando $o$ processo de ensinar e aprender, os planejamentos interdisciplinares, o compartilhamento de experiências pedagógicas exitosas e inclusivas, o conhecimento mais aprofundado dos estudantes, a avaliação e autoavaliação e a articulação do coletivo em torno da construção do projeto político-pedagógico da escola.

A garantia da coordenação pedagógica contribui para a superação da fragmentação do trabalho pedagógico, de sua rotinização (SILVA, 2007) e alienação dos trabalhadores em educação. Potencializar esse espaço-tempo viabiliza o alcance dos objetivos apresentados no Projeto Político-Pedagógico, favorecendo a constituição de processos inovadores de ensinar, aprender, pesquisar e avaliar. Ao mesmo tempo, recupera o sentido essencialmente coletivo do trabalho docente, realizado em contextos em que vários sujeitos se fazem presentes, influenciam histórias de vida e são influenciados por elas, pelos valores, concepções, saberes e fazeres uns dos outros.

O cotidiano escolar e os meios de comunicação anunciam a alta frequência do adoecimento dos profissionais da educação. A importância da fala e da escuta sobre a realidade do trabalho entre os pares constitui-se mecanismo que possibilita dar visibilidade à criatividade e inventividade (MEIRIEU, 2002) que esses profissionais têm implementado para superarem a resistência apresentada pela realidade às prescrições trabalhistas. Daí surge a importância da co-ordenação, como ação entre os pares, também, como espaço-tempo privilegiado dessa "escuta sensível" (BARBIER, 1993) sobre a prática pedagógica e o cotidiano escolar. 
Nessa perspectiva do trabalho coletivo e da "escuta sensivel" entre os pares, a discussão, elaboração, acompanhamento e avaliação do Projeto Político-Pedagógico possibilita a reavaliação das práticas institucionais, docentes e discentes, compartilhamento de experiências entre escolas, realização de atividades de reflexão do trabalho do professor, como conselho de classe, avaliação institucional, na perspectiva de trabalho solidário entre os pares (coordenação), em contraposição ao trabalho individualizado e solitário (ordenação).

Ao considerar a perspectiva da gestão crítico-reflexiva, sublinhamos a coordenação pedagógica, caracterizando-a como um espaço/tempo vivo, dinâmico, fundamentado na dialogicidade entre a comunidade escolar e a extraescolar, entre o real e o prescrito, entre a teoria e a prática, na busca da concretização do PPP da escola e, assim, vencer os desafios que inviabilizam as ações coletivas para a construção da educação pública de qualidade.

Essa concepção sustenta nossa compreensão de que a coordenação pedagógica, revestida de significado político-pedagógico, constitui-se em espaço/tempo de elaboração, implementação e avaliação do PPP. Dessa forma, fomenta-se a construção da ação coletiva, da formação continuada, da reflexão crítica das práticas pedagógicas e da escola como um todo, que contribuem para a consolidação da educação pública com qualidade social.

Nessa perspectiva, enfatizamos a concepção de trabalho coletivo, na qual possam ser traçados eixos constitutivos e imprescindíveis às práticas sistematizadas dos professores, apoiados pela gestão, de forma que todos se sintam corresponsáveis pela construção de uma prática educativa de qualidade. A coordenação precisa ser compreendida como espaço/tempo primordial para a gestão da escola.

Maren (2003) destaca a importância do resgate do professor enquanto pesquisador, que propõe teorias, modelos e tecnologias educacionais mais pertinentes para a prática e para as ações que o cotidiano escolar exige. Esta reflexão deve, essencialmente, partir da prática para a construção de conhecimentos pedagógicos. 
A chegada das Tecnologias Digitais ao campo educacional facilitou bastante o trabalho do educador, seja nos momentos educativos com os educandos, seja nos momentos de coordenação pedagógica.

A partir do momento que surgem tecnologias que começam a otimizar o trabalho e o tempo do educador, a situação melhora um pouco para esse profissional. Com computador e Internet quase todas essas atividades enumeradas no parágrafo anterior passam a ser feita em uma mesma ferramenta, em um único dispositivo que pode ser acoplado a outros e oferecer uma infinidade de possibilidades.

Ao entrevistarmos os egressos da Turma 2 se utilizam o computador para o planejamento de suas aulas, seja na elaboração de planejamento e materiais, seja para pesquisa de materiais e conteúdos, todos disseram utilizar em alguma medida, sendo que $27,3 \%$ usam sempre; outros $27,3 \%$ utilizam às vezes; outros $27,3 \%$ raramente usam e $18,0 \%$ quase sempre fazem utilização do computador ao realizar seu planejamento de aula, como retratado no Gráfico 3.

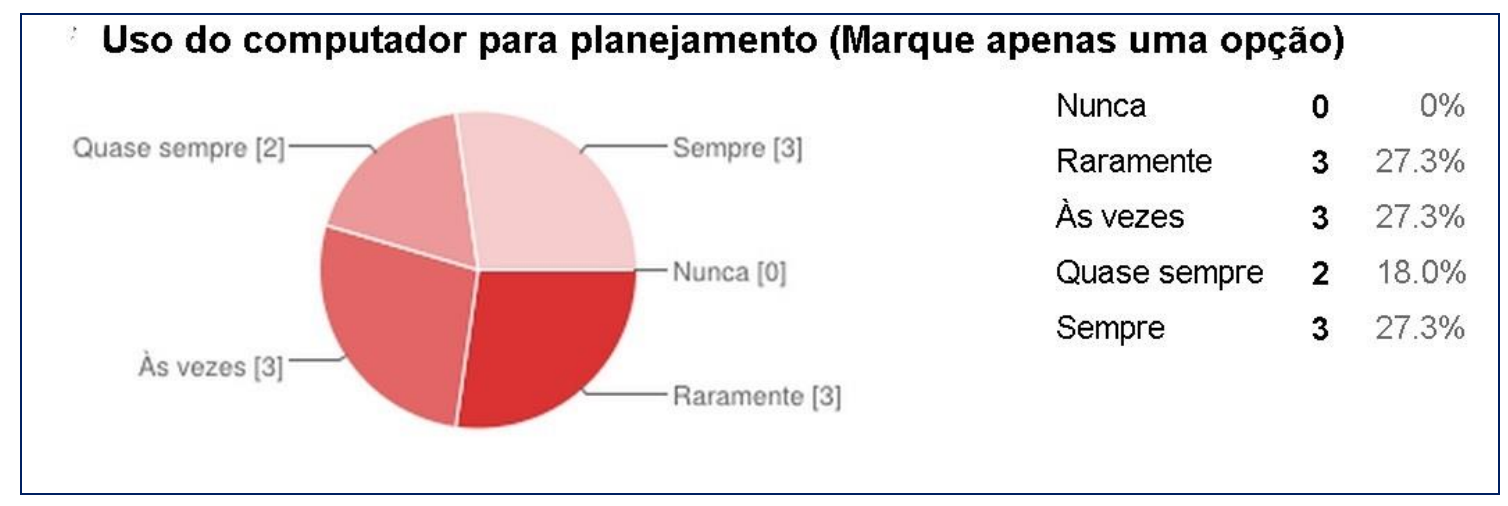

Gráfico 3: Uso do computador para planejamento das aulas

Assim como na questão anterior, ao serem interrogados sobre o uso de computador e Internet para preparar os materiais que utilizam em suas aulas, todos os entrevistados disseram utilizar, sendo que $27,3 \%$ raramente usam; $36,3 \%$ fazem uso às vezes; $18,2 \%$ empregam quase sempre e outros $18,2 \%$ dos entrevistados sempre utilizam computador e Internet para preparar materiais para suas aulas, segundo Gráfico 4. 


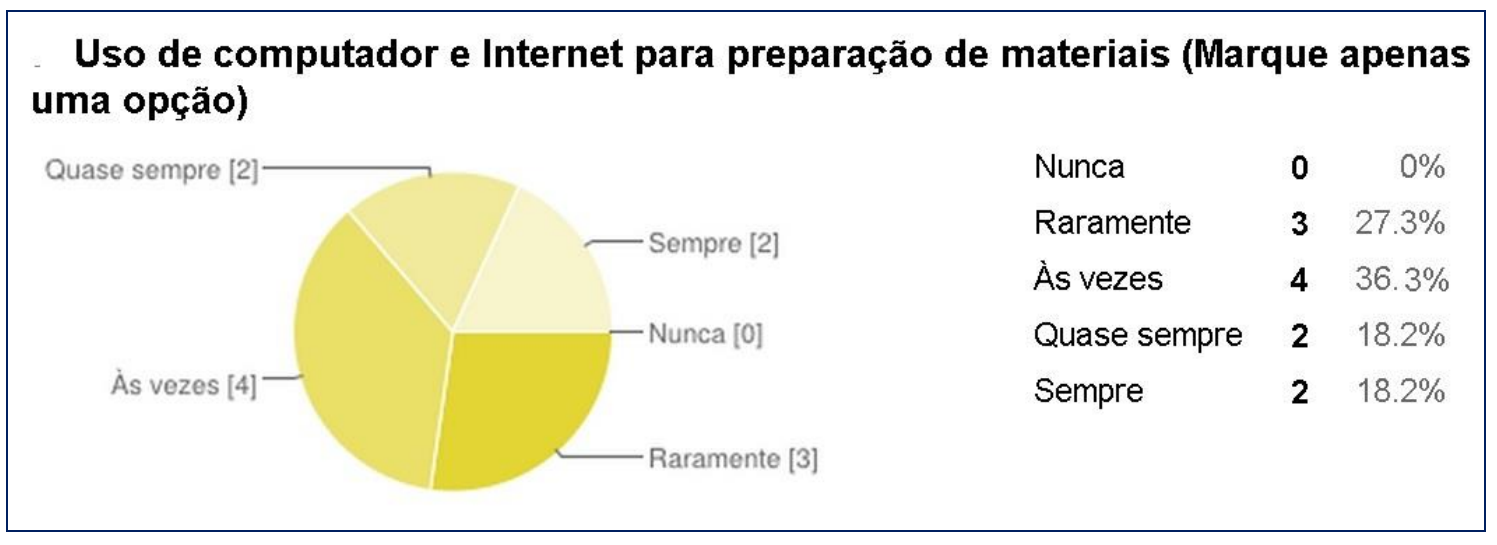

Gráfico 4: Uso do computador e Internet para preparação de materiais

No entanto, as Tecnologias Digitais não são a panaceia, elas por si só não resolvem os problemas de aprendizagem, pois as tecnologias necessitam do comando do usuário, que no caso, é o educador. E para que esse uso seja feito com eficiência e eficácia, torna-se imprescindível que o educador se forme para aproveitar todas as funcionalidades que elas podem oferecer, usando-as crítica e conscientemente.

Além disso, as Tecnologias Digitais trazem consigo o estigma de terem sido criadas para atender às demandas do modo de produção capitalista, para promover a alienação e para a opressão da classe trabalhadora. Ao utilizá-las, o educador precisa questionar se seus usos se prestam a esse serviço, à alienação, à opressão, à alimentação do capital.

É adequado pensar o uso dessas tecnologias na educação para além das funções integradas à perspectiva capitalista onde seu restrito papel é produzir o que for necessário e suficiente ao funcionamento da economia e produzir mão de obra de modo atrelado à elaboração de formas de controle político (MÉSZÁROS, 2006). É necessário que passemos a pensar no uso das Tecnologias Digitais para promover ações contra-hegemônicas que transformem essa ferramenta, inicialmente criada para a opressão, em mais um instrumento de promoção da cidadania e da luta contra todas as formas de opressão e submissão. Essas tecnologias, quando bem utilizadas podem auxiliar comunidades do campo a promover novas formas de lidar com 0 plantio e a produção da agricultura familiar; podem ser utilizadas para a venda direta dessa produção, sem a necessidade do "atravessador", que é mais um a explorar o pequeno agricultor; pode promover pesquisas de estratégias e 
metodologias apropriadas para lidar com os conflitos e as contradições que surgem em sua comunidade; pode, também, transformar as práticas pedagógicas e o currículo da Escola do Campo a favor de uma educação emancipatória e realmente transformadora; enfim, é possível tornar as Tecnologias Digitais em aliados na luta contra o modo de produção capitalista.

Para Mészáros,
A educação para além do capital visa a uma ordem qualitativamente diferente. Agora não só é factível lançar-se pelo caminho que nos conduz a essa ordem como o é também necessário e urgente. Pois as incorrigíveis determinações destrutivas da ordem existente tornam imperativo contrapor aos irreconciliáveis antagonismos estruturais do sistema do capital uma alternativa concreta e sustentável para a regulação da reprodução metabólica social, se quisermos garantir as condições elementares da sobrevivência humana. O papel da educação, orientado pela única perspectiva efetivamente viável de ir para além do capital, é absolutamente crucial para esse propósito (MÉSZÁROS, 2008, pp. 71-72).

\subsubsection{Tecnologias Digitais e Educação do Campo: um desafio}

Inquiridos sobre a utilização do computador no momento das aulas, $9,1 \%$ disse empregar sempre essa ferramenta, $54,5 \%$ disseram que às vezes utilizam o computador em suas aulas e $36,4 \%$ contaram que usam raramente 0 computador nas aulas, principalmente por falta desse recurso na escola, conforme Gráfico 5.

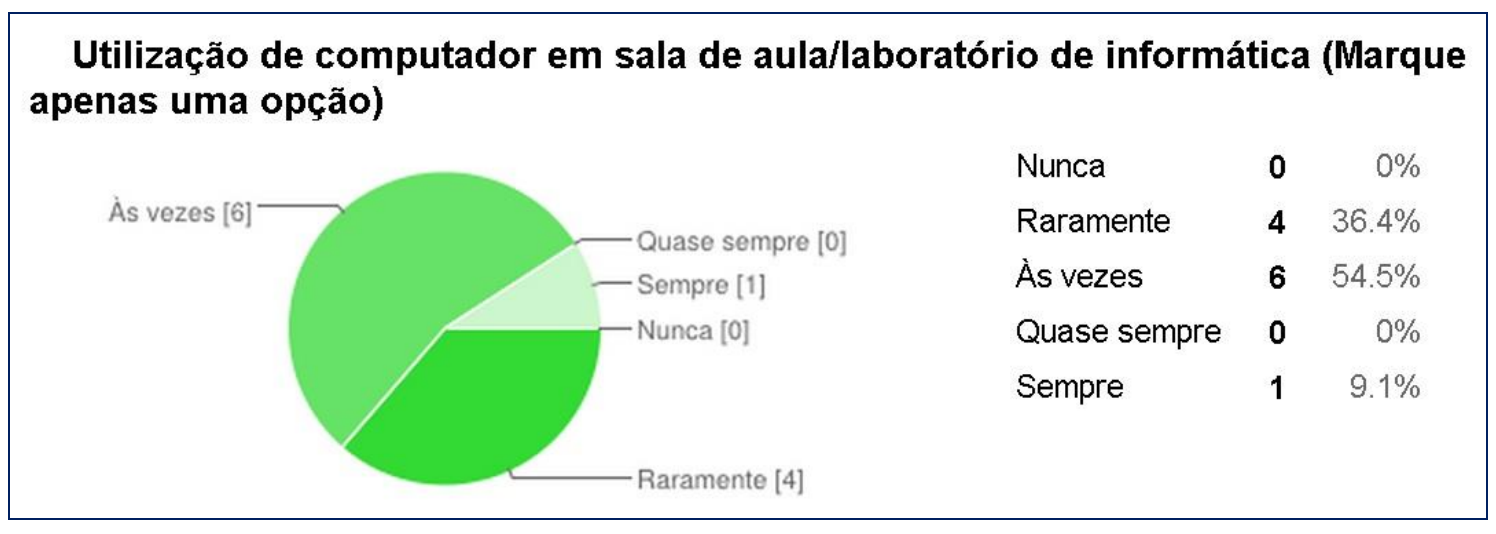

Gráfico 5: Utilização do computador para dar aulas

Quanto à localização em que é feita a utilização de computador e Internet com os educandos (e podendo indicar mais de um local), pudemos notar que esse uso é realizado em lugares bem diversificados: em $63,6 \%$ das vezes é utilizado o Laboratório de Informática da escola; em $27,3 \%$ das vezes 
esse uso é feito na Casa Digital; em outras $27,3 \%$ na própria sala de aula; em $9,1 \%$ na secretaria da escola e em $27,3 \%$ dos casos utilizam-se outros locais diferentes dos anteriormente citados, segundo o Gráfico 6.

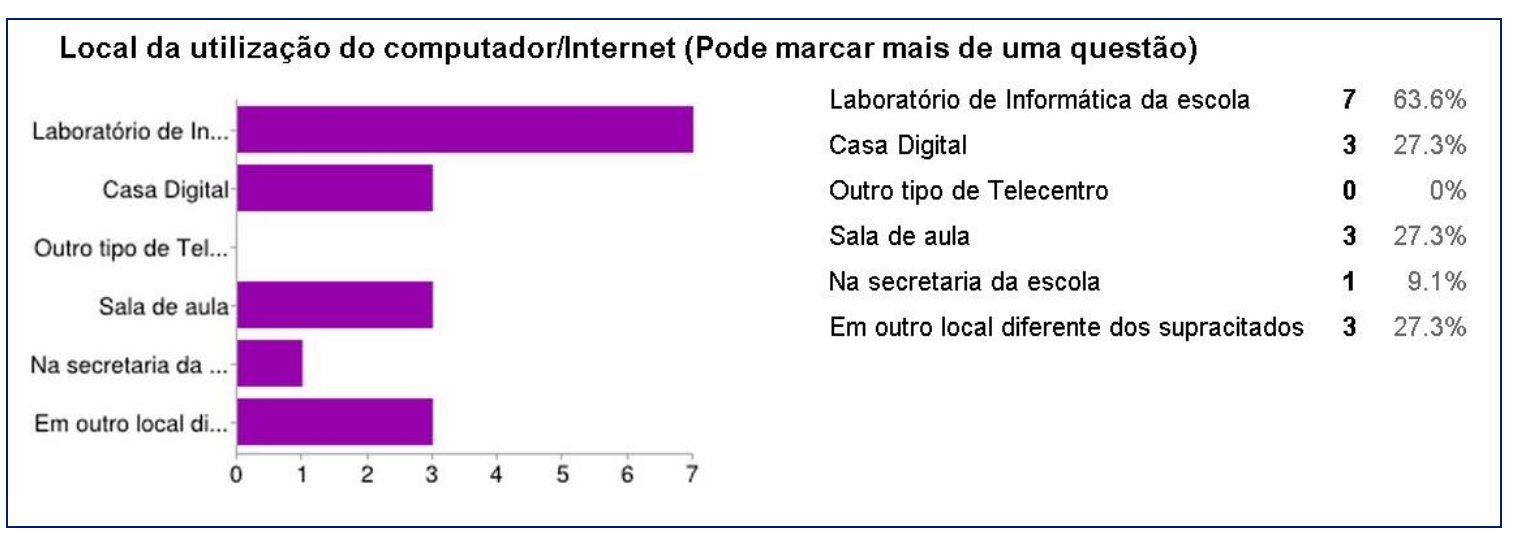

Gráfico 6: Local de utilização de computador e Internet para aulas

Como podemos notar pelas informações trazidas, ainda é grande o número de docentes que não utiliza as Tecnologias Digitais para o desenvolvimento do trabalho pedagógico nas escolas do campo e em grande parte dos casos, isso acontece pela falta da infraestrutura adequada para essa utilização, seja pela falta de espaço, energia ou das próprias tecnologias, que ainda não chegaram a todas as localidades onde atuam os educandos egressos da LEdoC-UnB.

Essa situação reflete o processo histórico de exclusão social sofrido pelo povo do campo desde a colonização do Brasil, situação essa que está intrinsecamente ligada ao modo de produção capitalista que submete os sujeitos da classe trabalhadora a todo tipo de opressão, principalmente, a partir da ausência de políticas públicas específicas.

Sobre os modos de utilização do computador nas aulas, os entrevistados podiam responder quantos usos quisessem para nos dar uma noção de quais programas eles estão fazendo uso. O uso do computador para exibir ou explorar filmes é utilizado por $63,6 \%$ dos entrevistados, seguido de utilização frequente para fazer pesquisas na Web com os educandos, sendo $45,5 \%$. Seguido do uso para apresentações de slides, 36,4\%. E 27,3\%, para utilização de editor de texto. Os demais usos apontados pelos entrevistados foram: materiais de autoria própria (imagens, textos, apresentações, etc.), 18,2\%; editor de imagens, reproduzir áudio ou músicas e disponibilizar jogos 
digitais, também 18,2\%. Uso de blogs e outros modos de uso não apresentados aos entrevistados, 9,1\%. Nenhum dos entrevistados apontou: uso de objetos de aprendizagem encontrados na rede; utilização de tabelas e planilhas; uso de recursos educacionais abertos encontrados na Web; emprego de ambientes virtuais de aprendizagens; e nem uso de simulações, conforme podemos observar no Gráfico 7. 


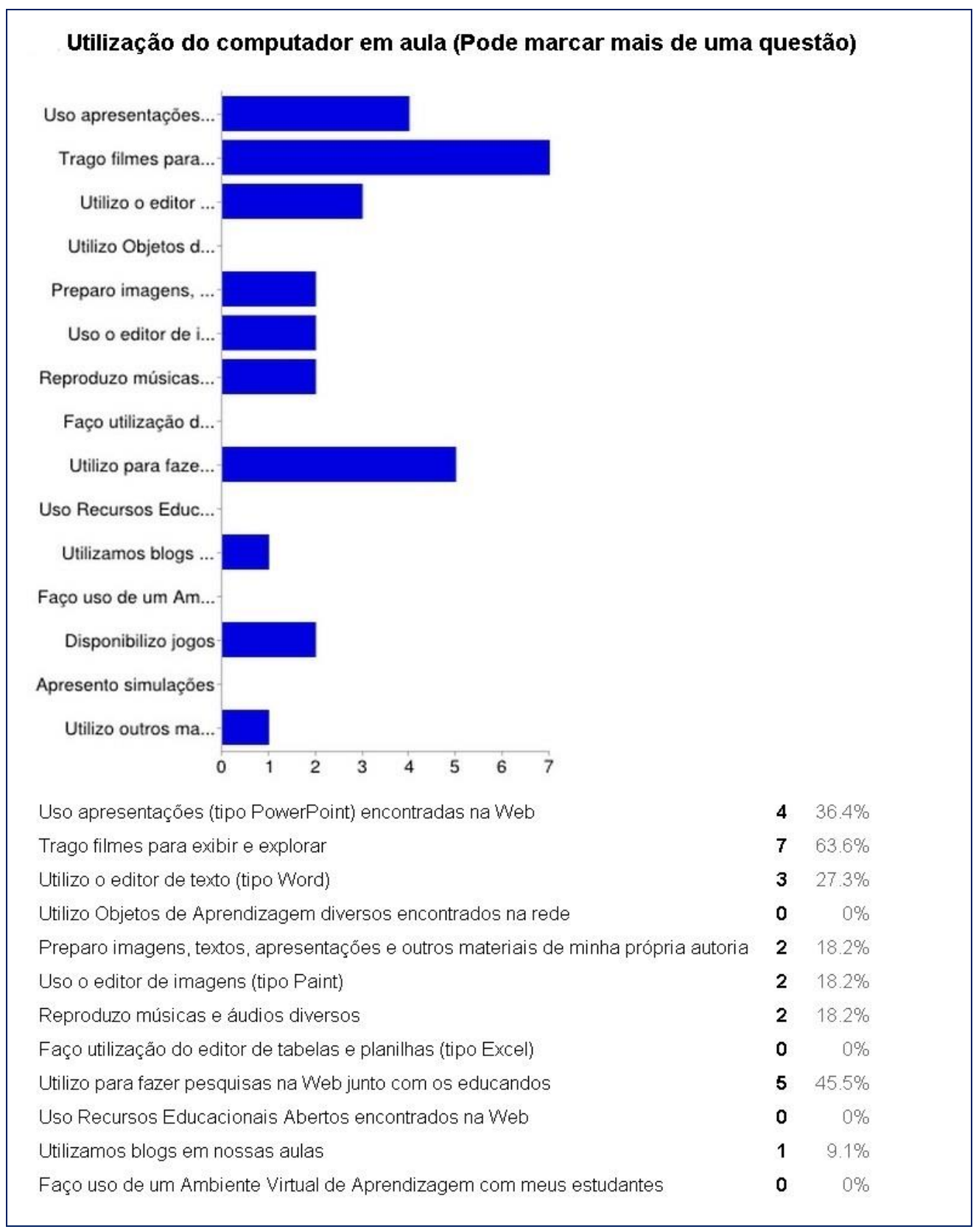

Gráfico 7: Modos de utilização do computador

Notamos, com isso, que ainda são poucos os educadores que aproveitam os REA para autoria, talvez por falta de formação específica para tal uso, talvez por falta de recursos materiais ou conhecimentos pedagógicos que lhes possibilitem para fazê-lo.

Uma das oportunidades proporcionadas pelo uso de Recursos Educacionais Abertos é a de coaprendizagem ou aprendizagem colaborativa, isto é, possibilita que educadores e educandos aprendam juntos em processos 
de autoria e de remixagem. Em outras palavras, essa coaprendizagem consiste na utilização de ferramentas de mídia social para promover a aprendizagem aberta e colaborativa, envolvendo redes sociais abertas na produção, adaptação, partilha e disseminação de REA colaborativamente (OKADA, MICROYANNIDIS, MEISTER \& LITTLE, p. 166).

Este quadro nos mostra o quanto ainda se faz necessário e urgente realizar formações diversas junto aos educadores do campo em razão da dívida histórica que temos com as comunidades do campo. Em áreas que, na cidade, não mostra tanta necessidade de formação, esses sujeitos se mostram um tanto carentes de informações.

\subsubsection{Sujeitos do campo, relações educativas e Tecnologias Digitais}

Ao questionarmos o que mudou na prática pedagógica dos entrevistados depois que começaram a utilizar o computador e a Internet, obtivemos as seguintes respostas para nossa reflexão:

\begin{tabular}{|c|c|}
\hline Nome fictício: & Resposta: \\
\hline Diadorim & $\begin{array}{l}\text { Na minha comunidade, os computadores estão servindo } \\
\text { apenas para enfeitar as mesas, porque tem gente que está } \\
\text { com o pezão em cima e não quer nos repassar a senha, além } \\
\text { de faltar equipamentos, por ter desaparecidos após essa } \\
\text { pessoa ter recebido os computadores e ficado aqui na cidade } \\
\text { por um período de mais de dois } 2 \text { anos. Os computadores só } \\
\text { chegaram na comunidade em julho de } 2014 \text { e estão lá sem } \\
\text { poder serem usados por falta de senhas. Já tentei entrar em } \\
\text { contato com o MDA, mas sem sucesso por falta de contato do } \\
\text { departamento que cuida dessa área. }\end{array}$ \\
\hline Davidão & $\begin{array}{l}\text { Bom como moro em Assentamento e não temos acesso a } \\
\text { internet, são poucas as vezes q posso utilizar essas } \\
\text { tecnologias, mas as vezes q utilizei ajudaram muito no } \\
\text { desenvolvimento das matérias. }\end{array}$ \\
\hline Maria Leôncia & $\begin{array}{l}\text { Bom como moro em Assentamento e não temos acesso a } \\
\text { internet, são poucas as vezes q posso utilizar essas } \\
\text { tecnologias, mas as vezes q utilizei ajudaram muito no } \\
\text { desenvolvimento das matérias. }\end{array}$ \\
\hline Riobaldo & $\begin{array}{l}\text { Aula diversificada, aulas atrativas que contribui para o ensino } \\
\text { aprendizagem. }\end{array}$ \\
\hline Medeiro Vaz & $\begin{array}{l}\text { Abre novas possiblidades de materiais didáticos. Além de } \\
\text { proporcionar muitas fontes de pesquisa. }\end{array}$ \\
\hline Otacília & $\begin{array}{l}\text { Mas material didático. Trabalha Com outros autores, e não } \\
\text { ficar refém só dos materiais que são mandando para a escola, }\end{array}$ \\
\hline Doutor Fausto & $\begin{array}{l}\text { Facilita a preparação de materiais e dos planejamentos, pela } \\
\text { diversidade de conteúdos encontrados. }\end{array}$ \\
\hline Joca Ramiro & $\begin{array}{l}\text { Tem sido um auxílio fundamental, pois, tem contribuído muito } \\
\text { mais com o ensino aprendizagem dos educandos e com o } \\
\text { desenvolvimento das atividades em sala de aula. }\end{array}$ \\
\hline Nhorinhá & Não respondeu. \\
\hline Hermógenes & $\begin{array}{l}\text { Facilitou o planejamento e a pesquisa de materiais para } \\
\text { utilização em aula. Também acho que melhorei minha escrita }\end{array}$ \\
\hline
\end{tabular}


\begin{tabular}{|l|l|} 
& e leitura, o que melhora minha prática também. \\
\hline Zé Bebelo & Ampliação dos horizontes de aprendizagens. \\
\hline
\end{tabular}

Tabela 2: Mudanças na prática pedagógica após o uso de computador e Internet

A partir das respostas dos entrevistados, podemos notar que é uma unanimidade entre eles que computador e Internet facilitam o trabalho do educador e sua prática pedagógica. Para o grupo, essas melhorias acontecem tanto no processo de preparação das aulas quanto nas práticas com os educandos.

Destacamos, nas respostas, aquelas que se referem a novas possibilidades de materiais didáticos, ou seja, embora muitos tenham respondido que não sabiam o que era REA, eles já tinham a noção de que existem materiais disponíveis na rede e que podem ser baixados e utilizados.

Outra resposta bastante relevante foi a do egresso Hérmogenes quando este diz "acho que melhorei minha escrita e leitura, o que melhora minha prática também”. Esse é um aspecto crucial no acesso e uso das Tecnologias Digitais, sua utilização para a autoaprendizagem e para a autoformação. Muitas pessoas criticam as tecnologias, mas se esquecem que seu emprego depende de quem o empreende. Em nossas aulas de Comunicação e Tecnologias da Informação reforçamos bastante essa ideia de que computador e Internet podem mudar nossa vida a partir da nossa disposição em buscar, pesquisar, utilizar as tecnologias para aprender o que temos vontade, desenvolver o que é de nosso interesse. Se os sujeitos percebem isso, ele tem inúmeras possibilidades nas mãos e isso está dito na resposta de Zé Bebelo quanto ele responde "ampliação dos horizontes de aprendizagens".

Para Masetto (2000), a tecnologia apresenta-se como meio, como instrumento para colaborar no desenvolvimento do processo de aprendizagem. A tecnologia reveste-se de um valor relativo e dependente desse processo. Ela tem sua importância apenas como um instrumento significativo para favorecer a aprendizagem de alguém (MASETTO, 2000, p. 139).

No entanto, faz-se necessário lembrar que o trabalho docente não deve ser individualizado, todo o coletivo da escola precisa estar envolvido na formação dos educandos. Sobre essa questão, Pais (2002) nos lembra que 
No contexto da atualidade, ao estudar a inserção dos computadores na educação escolar, a diferença está na possibilidade de multiplicar as condições de organizar coletivos inteligentes através do uso das redes de computador e outras interfaces digitais. Acreditamos que o importante dessa possibilidade é explicitar, pela via tecnológica, a dimensão coletiva do trabalho e projetá-la no quadro de uma ampliação dos atuais recursos educacionais (PAIS, 2002, P. 35).

Ao falar nos coletivos inteligentes, Pais (2002) se refere à ideia de inteligência coletiva defendida por Pierre Lévy e que é definida como sendo a possibilidade de que a união de competências individuais de uma equipe pode produzir resultados mais expressivos do que a soma dos resultados particulares de cada membro dessa equipe. Este é um dos conceitos descritos por Lévy no livro A inteligência Coletiva ${ }^{14}$. Faz-se imprescindível destacar que o conceito não se aplica apenas às questões relacionadas ao uso de tecnologias de informação e comunicação, mas tem abrangência em todas as dimensões da vida humana.

Outro ponto a ser destacado é que esse uso e o fato dele movimentar os educadores no sentido do trabalho coletivo facilita e proporciona espaços e tempos para que a interdisciplinaridade seja colocada em prática, pois ela só é possível quando há um trabalho de parceria entre os docentes das diferentes áreas do conhecimento.

Pais continua sua ideia dizendo que na atual tendência de formação docente está a necessidade de valorizar a criação de dinâmicas coletivas de trabalho no âmbito das próprias instituições escolares e que essa iniciativa tem como objetivo motivar a participação dos próprios professores na solução dos atuais desafios pedagógicos da educação escolar (PAIS, 2002, p.35).

\subsubsection{Maior horizontalidade na relação educando-educador}

Indagados sobre o que mudou na sua relação com os estudantes a partir do uso das Tecnologias Digitais nas suas aulas, obtivemos como respostas:

\begin{tabular}{|l|l|}
\hline \multicolumn{1}{|c|}{ Nomes fictícios: } & \multicolumn{1}{c|}{ Respostas: } \\
\hline Diadorim & $\begin{array}{l}\text { A vivência dos estudantes com o computador muda } \\
\text { bastante, por que para eles ainda é algo novo. }\end{array}$ \\
\hline Davidão & Percebi mais interesse dos educandos/as em aula. \\
\hline Maria Leôncia & Percebi mais interesse dos educandos/as em aula. \\
\hline
\end{tabular}

\footnotetext{
${ }^{14}$ LÉVY, Pierre. A inteligência coletiva: por uma antropologia do ciberespaço. São Paulo: Edições Loyola, 1998.
} 


\begin{tabular}{|l|l|} 
Riobaldo & $\begin{array}{l}\text { Houve um maior interesse dos estudantes quando } \\
\text { as aulas era expositiva com slides, filmes e } \\
\text { músicas. }\end{array}$ \\
\hline Medeiro Vaz & $\begin{array}{l}\text { Estudar novas tecnologias é falar uma linguagem } \\
\text { dos estudantes. Estes sempre gostam de aulas } \\
\text { dessa maneira. }\end{array}$ \\
\hline Otacília & $\begin{array}{l}\text { Mas material para melhorar o desempenho dos } \\
\text { educados em sala de aula. e aula com mais } \\
\text { dinâmico, mas envolvimento e participação em sala } \\
\text { de aula. }\end{array}$ \\
\hline Doutor Fausto & $\begin{array}{l}\text { Começamos a desconstruir a ideia de que a } \\
\text { aprendizagem se limita a apenas ao quadro giz e } \\
\text { livro didático. }\end{array}$ \\
\hline Joca Ramiro & $\begin{array}{l}\text { A relação de professor e aluno tem se tornado } \\
\text { muito mais equilibrada. Pois os educandos tem se } \\
\text { demonstrado mais interessados quando se utiliza } \\
\text { das tecnologias no desenvolvimento das aulas. }\end{array}$ \\
\hline Nhorinhá & Não respondeu. \\
\hline Hermógenes & $\begin{array}{l}\text { Passamos a ter uma relação mais humanizada, de } \\
\text { igual pra igual. Eu ensino para eles e eles me } \\
\text { ensinam. Eles sabem mais do uso das tecnologias } \\
\text { que eu, então fazemos uma troca. }\end{array}$ \\
\hline Zé Bebelo & $\begin{array}{l}\text { Confiabilidade com os educandos/as maior } \\
\text { interação. }\end{array}$ \\
\hline
\end{tabular}

Tabela 3: Relação educando-educador após as Tecnologias Digitais

Quando perguntamos sobre como se relacionam com os educandos, boa parte dos educadores remete o pensamento aos conteúdos, à matéria, à aula em si, mas também à questão das relações entre educador-educando sobre como eu enxergo o outro e como ele me enxerga, sobre se existe respeito, confiança, amizade, carinho entre educador e educando e vice-versa.

Pensemos, então: relação mais humanizada, troca de saberes e confiabilidade foram as palavras-chave que surgiram em algumas das respostas, o que nos leva a refletir que o trabalho com tecnologias quebra a hierarquização e a frieza da relação educador-educando, gerando sentimento de respeito às diferenças, confiança e segurança para interagir, se relacionar. Sobre isso nos diz Castro (2008) ao falar de aulas mediadas por computador e Internet:

Esta nova forma de se desenvolver um trabalho pedagógico acaba por gerar um novo modo de relação professor-aluno. Com a entrada dos computadores na Educação as informações passam a estar disponíveis na Internet e os alunos podem acessá-las a qualquer momento. O professor deixa de ser 0 "detentor do conhecimento" para ser um mediador, um facilitador das relações entre os estudantes e as informações acessadas. É o professor que ajudará os alunos a interpretar, fazer a seleção e transformar em conhecimento as informações mais relevantes para o seu aprendizado. A relação deixa de ser 
vertical e hierarquizada para ser horizontal, na qual os atores do processo - alunos e professor - passam a ser sujeitos que se ajudam mutuamente e interagem (CASTRO, 2008, p.60).

Dentro das demais respostas, destacamos a resposta de Medeiro Vaz que se refere à questão da linguagem: "Estudar novas tecnologias é falar uma linguagem dos estudantes. Estes sempre gostam de aulas dessa maneira". Isso nos remete a um problema grave na educação brasileira e que é pouco discutida nos cursos de formação docente, isto é, não estamos falando a mesma linguagem que os educandos, como podemos querer que eles nos compreendam? Ninguém presta atenção no que não entende. Se nos fazemos entender e thes ensinamos a linguagem "da escola" e do formal, teremos uma via de diálogo aberta.

Arroyo (2011) nos auxilia na compreensão que

A disputa está posta na prática cotidiana da própria centralidade, quase exclusividade, dada ao letramento desde o pré-escolar. Disputa enriquecedora por concepções de letramento. Uma concepção restritiva como domínio de competências e habilidades? Muito mais? Avança uma concepção de linguagem como comunicação, como suporte e organização do pensamento, como interação entre sujeitos. Énfase na linguagem como expressão, negociação de sentidos, de revelações e leituras de mundo e dos próprios sujeitos, de identidades, culturas e valores (ARROYO, 2011, $p$ 221).

Para completar, Arroyo defende que

a organização do trabalho pedagógico centrado na exploração das relações, convívios, interações e até tensões em situação comunicativa pode levar nessa direção formadora, reveladora do humano que desde crianças se vivencia (2011, p 221).

\subsubsection{Maior horizontalidade na relação educando-conhecimento}

Já, quando falamos sobre o relacionamento dos educandos com o conhecimento, perguntamos aos entrevistados o que mudou na forma como os educandos se relacionam com o conhecimento a partir do uso do computador nas aulas, os entrevistados responderam:

\begin{tabular}{|l|l|}
\hline \multicolumn{1}{|c|}{ Nomes fictícios: } & \multicolumn{1}{c|}{ Respostas: } \\
\hline Diadorim & $\begin{array}{l}\text { Mudou muito, primeiro porque tem estudante na minha } \\
\text { comunidade que se quer conhece um computador. } \\
\text { Então eu uso meu notebook para trabalhar aulas } \\
\text { diferenciadas. }\end{array}$ \\
\hline Davidão & Não respondeu \\
\hline
\end{tabular}




\begin{tabular}{|l|l|} 
Maria Leôncia & Não respondeu \\
\hline Riobaldo & $\begin{array}{l}\text { Ao apresentar maior interesse nas aulas a partir das } \\
\text { tecnologias, isso trouxe um avanço no ensino e } \\
\text { aprendizagem. }\end{array}$ \\
\hline Medeiro Vaz & $\begin{array}{l}\text { Demostraram mais interesse e se motiva cada vez } \\
\text { mais. }\end{array}$ \\
\hline Otacília & $\begin{array}{l}\text { Geralmente os educados quase não tem acesso ao } \\
\text { computador em sala de aula. }\end{array}$ \\
\hline Doutor Fausto & $\begin{array}{l}\text { Eles acham as aulas mais dinâmicas interessantes, o } \\
\text { que facilita a compreensão do conteúdo. Um fator } \\
\text { importante é que o computador e a internet oferecem } \\
\text { uma variedade de recursos que possibilita ao } \\
\text { estudante a compreensão e a associação dos } \\
\text { conceitos da realidade. }\end{array}$ \\
\hline Joca Ramiro & $\begin{array}{l}\text { Com o auxílio do computador e da Internet os } \\
\text { educandos tem se relacionado de maneira prazerosa. } \\
\text { Pois, tem buscado interagir com o conhecimento com } \\
\text { muita agilidade e praticidade. } \\
\text { Não respondeu. }\end{array}$ \\
\hline Nhorinhá & $\begin{array}{l}\text { Eles passaram a gostar mais da aula. Parece que } \\
\text { agora têm mais incentivo para estudar. Antes ficavam } \\
\text { meio entediados. Também passaram a gostar de } \\
\text { pesquisar o que querem aprender. }\end{array}$ \\
\hline Hermógenes & $\begin{array}{l}\text { Aprendizados uniformes, maiores intervenções nas } \\
\text { aulas. }\end{array}$ \\
\hline Zé Bebelo &
\end{tabular}

Tabela 4: Relação educando-conhecimento após as Tecnologias Digitais

Quando observamos as respostas a essa questão, percebemos claramente que a dinâmica da sala de aula muda se inserimos Tecnologias Digitais como um recurso didático-pedagógico nas aulas. Isso acontece por vários motivos, mas um deles, e talvez o mais significativo, seja porque, como diz Kenski,

A tecnologia digital rompe com a narrativa contínua e sequencial das imagens e textos escritos e se apresenta como um fenômeno descontínuo. Sua temporalidade e espacialidade, expressas em imagens e textos nas telas estão diretamente relacionadas ao momento de sua apresentação. Verticais, descontínuos, móveis e imediatos, as imagens e os textos digitalizados a partir da conversão das informações em bytes têm o seu próprio tempo, seu próprio espaço fenomênico da exposição. Eles representam, portanto um outro tempo, um outro momento revolucionário, na maneira de pensar e de compreender (KENSKI, 1998 apud BEHRENS, 2000, p.75).

E Behrens complementa dizendo que os educandos passam a ser descobridores, transformadores e produtores de conhecimento (BEHRENS, 2000, p.75).

\subsubsection{Facilidades e dificuldades no uso de Tecnologias Digitais}


Ao questionarmos o que os entrevistados acham que o uso de Tecnologias Digitais Ihes proporcionaram, se facilidades ou dificuldades no trabalho pedagógico e o porquê, as respostas foram:

\begin{tabular}{|l|l|}
\hline \multicolumn{1}{|c|}{ Nomes fictícios: } & \multicolumn{1}{c|}{ Respostas: } \\
\hline Diadorim & $\begin{array}{l}\text { Em relação aos telecentros BR ou Casas Digitais, só } \\
\text { dificultou, porque os estudantes pedem para usar os } \\
\text { computadores e não podemos. }\end{array}$ \\
\hline Davidão & $\begin{array}{l}\text { Facilidades, é claro, já que contribui no aprendizado } \\
\text { dos educandos/as. }\end{array}$ \\
\hline Maria Leôncia & Facilidades, pois contribui no aprendizado. \\
\hline Riobaldo & $\begin{array}{l}\text { Houve um avanço em questão de apresentação de } \\
\text { slide, filmes e músicas, mas infelizmente a internet não } \\
\text { é utilizada em sala de aula por que a única que existe } \\
\text { na escola é de uso da secretaria e ainda assim é de } \\
\text { péssima qualidade. }\end{array}$ \\
\hline Medeiro Vaz & $\begin{array}{l}\text { Facilidades. Mas a dificuldade foi devido ao acesso ser } \\
\text { precário no campo. Os computadores apresentam } \\
\text { muitos problemas operacionais. A internet é bastante } \\
\text { lenta. }\end{array}$ \\
\hline Otacília & $\begin{array}{l}\text { O material didático no acesso à informação, } \\
\text { a maior dificuldade é que nem todos os educados tem } \\
\text { acesso a Internet. Os laboratórios na escola raramente } \\
\text { funcionam. }\end{array}$ \\
\hline Doutor Fausto & $\begin{array}{l}\text { As facilidades vão desde o planejamento, que inclui a } \\
\text { busca por materiais e metodologias de trabalho, e a } \\
\text { prática educativa, uma vez que os alunos se } \\
\text { interessam cada vez mais por aulas que tem os } \\
\text { processos metodológicos diferenciados. }\end{array}$ \\
\hline Nhorinhá & $\begin{array}{l}\text { O uso de tecnologias tem me proporcionado facilidade } \\
\text { no trabalho pedagógico. Pois, estamos passando por } \\
\text { um momento em que já não tem condições de um } \\
\text { educador ficar a mercê das tecnologias em seu } \\
\text { trabalho pedagógico. }\end{array}$ \\
\hline Hermógenes & $\begin{array}{l}\text { Não respondeu. } \\
\text { nom certeza facilitou meu trabalho. É uma pena que } \\
\text { contrário, penso que seria muito mais fácil desenvolver } \\
\text { o trabalho. }\end{array}$ \\
\hline Joca Ramiro & $\begin{array}{l}\text { Facilidades. } \\
\text { Aproveito vários sites para ajudar no processo de } \\
\text { aprendizagem dos educandos/as. }\end{array}$ \\
\hline
\end{tabular}

Tabela 5: Facilidades e dificuldades no trabalho pedagógico com apoio das Tecnologias Digitais

Pelo que notamos, quase todos os respondentes disseram que tiveram dificuldades, devido às condições de infraestrutura e de conectividade são bem precárias em suas comunidades. E quase todos também perceberam avanços. As dificuldades estão relacionadas, principalmente, à falta de apoio e manutenção das Casas Digitais instaladas em suas comunidades, pois faziam parte de um Programa de governo que acabou. Infelizmente, as comunidades têm muita dificuldade para gerir essas Casas devido à falta de formação e 
informação. E como os docentes, que têm certa formação, mas que não dispõem de tempo para dedicar à Casa Digital, passam por essa situação. Além disso, tem a dificuldade financeira para compra de peças.

Quanto aos avanços, podemos separar em duas diferentes categorias, uma que é a do trabalho de coordenação pedagógica (pesquisa e preparação de materiais, planejamento de aulas, etc.) e outra que é na forma dos educandos lidarem com o conhecimento e com as aulas, consequentemente. No final, as duas categorias se encontram em um só resultado: melhoria da aprendizagem dos educandos.

\subsubsection{Recursos Educacionais Abertos e Educação do Campo: potencialidades à vista}

Questionados se já tinham ouvido falar em Recursos Educacionais Abertos ou REA, $81,8 \%$ disseram que não e 18,2\% falaram que sim. $O$ interessante é que nas aulas de CTI tratamos desse tema, no entanto, como já se passaram quase dois anos do término das aulas, pode ser que tenham se esquecido, pois à época os REA não eram tão divulgados e utilizados como agora.

Ao indagarmos o que, para os entrevistados, são Recursos Educacionais Abertos, também chamados de REA e deixando claro que poderia ser o que eles já ouviram falar ou o que imaginavam ser, mas com suas palavras, obtivemos como respostas:

\begin{tabular}{|l|l|}
\hline \multicolumn{1}{|c|}{ Nomes fictícios: } & \multicolumn{1}{c|}{ Respostas: } \\
\hline Diadorim & $\begin{array}{l}\text { Ainda não tive contato com este tipo de recurso, mas } \\
\text { acredito que seja bom. }\end{array}$ \\
\hline Davidão & $\begin{array}{l}\text { Não sei o q é REA, mas acredito q sejam recursos } \\
\text { educacionais q poderemos ter acesso para facilitar } \\
\text { nossa docência. }\end{array}$ \\
\hline Maria Leôncia & $\begin{array}{l}\text { Não sei o que é REA, mas acredito q sejam materiais } \\
\text { que poderemos ter acesso para facilitar nossa } \\
\text { docência. }\end{array}$ \\
\hline Riobaldo & Sites de acesso livre para uso educacional. \\
\hline Medeiro Vaz & $\begin{array}{l}\text { Não ouvi falar. Deve ter alguma coisa a ver com as } \\
\text { novas tecnologias educacionais. }\end{array}$ \\
\hline Otacília & $\begin{array}{l}\text { Então não tiver acesso a esse recurso e acho que na } \\
\text { escola também não. }\end{array}$ \\
\hline Doutor Fausto & $\begin{array}{l}\text { Imagino que sejam recursos que podem ser } \\
\text { acessados livremente por educadores e alunos e que } \\
\text { oferecem uma variedade de possibilidades de } \\
\text { adaptações e usos de acordo com a realidade dos } \\
\text { educandos e educadores. }\end{array}$ \\
\hline Na verdade ainda não tinha ouvido falar... \\
\hline Joca Ramiro &
\end{tabular}




\begin{tabular}{|c|c|}
\hline Nhorinhá & Não respondeu \\
\hline Hermógenes & $\begin{array}{l}\text { Ouvi falar poucas vezes, mas pelo que entendi, são } \\
\text { materiais digitais que qualquer pessoa pode fazer e } \\
\text { postar e outras pessoas podem usar, modificar e } \\
\text { postar novamente. Ou seja, são materiais disponíveis } \\
\text { na Internet que podem ser usados e modificados sem } \\
\text { ninguém cobrar por esse uso ou modificação. }\end{array}$ \\
\hline Zé Bebelo & Materiais de estudos disponíveis em mídias etc. \\
\hline
\end{tabular}

Tabela 6: $O$ que são REA?

Dentre os que tentaram responder o que imaginavam ser, encontramos respostas bastante próximas à definição de REA:

\begin{tabular}{|l|l|}
\hline \multicolumn{1}{|c|}{ Nomes fictícios: } & \multicolumn{1}{c|}{ Respostas: } \\
\hline Riobaldo & Sites de acesso livre para uso educacional. \\
\hline Doutor Fausto & $\begin{array}{l}\text { Imagino que sejam recursos que podem ser acessados } \\
\text { livremente por educadores e alunos e que oferecem } \\
\text { uma variedade de possibilidades de adaptaçóe e usos } \\
\text { de acordo com a realidade dos educandos e } \\
\text { educadores. }\end{array}$ \\
\hline Hermógenes & $\begin{array}{l}\text { Ouvi falar poucas vezes, mas pelo que entendi, são } \\
\text { materiais digitais que qualquer pessoa pode fazer e } \\
\text { postar e outras pessoas podem usar, modificar e } \\
\text { postar novamente. Ou seja, são materiais disponíveis } \\
\text { na Internet que podem ser usados e modificados sem } \\
\text { ninguém cobrar por esse uso ou modificação. }\end{array}$ \\
\hline Zé Bebelo & Materiais de estudos disponíveis em mídias etc. \\
\hline
\end{tabular}

Tabela 7: Definição de REA

Após reapresentarmos a definição de $R E A^{15}$, perguntamos se eles já tinham utilizado algum tipo de REA em suas aulas, ao que $36,4 \%$ disseram que nunca utilizaram nenhum tipo de REA em suas aulas. 27,3\% afirmaram usar sempre, mesma quantidade dos que falaram que usam quase sempre. E 9,0\% declararam já terem utilizado uma ou duas vezes em suas aulas, de acordo com o Gráfico 8.

Analisando esse quadro, constatamos que, apesar de não saberem ao certo o que são REA, 63,6\% dos entrevistados fazem uso desses recursos em suas aulas pelo menos algumas vezes. Pensemos nisso como uma enorme

\footnotetext{
${ }^{15}$ São materiais de ensino, aprendizado, e pesquisa em qualquer suporte ou mídia, que estão sob domínio público, ou estão licenciados de maneira aberta, permitindo que sejam utilizados ou adaptados por terceiros. $\mathrm{O}$ uso de formatos técnicos abertos facilita o acesso e o reuso potencial dos recursos publicados digitalmente. Recursos educacionais abertos podem incluir cursos completos, partes de cursos, módulos, livros didáticos, artigos de pesquisa, vídeos, testes, software, e qualquer outra ferramenta, material ou técnica que possa apoiar o acesso ao conhecimento (STAROBINAS, 2012, pp.122-123)
} 
potencialidade, isto é, imaginemos esses $63,6 \%$ de docentes criando seus materiais juntamente com os educandos e retratando a realidade em que a escola está inserida, bem como a comunidade e todos os bens culturais que pertencem a ela. Isto é possível! Starobinas (2012) faz discussão nesse sentido quando diz que

Pensar em projetos que façam uso de REA na sua estruturação condiz com uma diretriz importante salientada nos marcos educacionais contemporâneos: a busca de interdisciplinaridade. Uma das críticas frequentes à escola nos moldes da sociedade industrial é sua tendência a compartimentar o conhecimento e oferecê-lo encapsulado, praticamente sem interação entre as chamadas disciplinas escolares. Propor a abertura dos recursos educacionais é também uma oportunidade de trabalhá-los fazendo uso conjunto de diferentes referenciais disciplinares. Isso vale tanto na articulação para compreender um determinado fenômeno, quanto para a produção de outros recursos, que podem surgir como desdobramento de um projeto: textos, vídeos, softwares etc.

O enfoque interdisciplinar nos permite ganhos no compartilhamento do conhecimento e da criatividade dos diferentes profissionais e também dos alunos. Quando esse tipo de proposta aparece de forma genuína, ela emerge de discussões que surgem entre os educadores ou partem dos alunos e se mostram legítimas e compatíveis à inserção no currículo praticado (STAROBINAS, 2012, p. 125).

Se utilizando os REA como utilizam os docentes já sentem sensíveis melhoras no aprendizado dos educandos e nas relações existentes naquele espaço educativo, imaginemos a concretização de projetos como descritos por Starobinas (2012). Neste projeto de pesquisa, nossa intenção era exatamente esta, entretanto, não foi possível realizar mais esta estratégia, além das realizadas, devido a problemas de diversas ordens: falta de infraestrutura na Universidade e nas comunidades envolvidas; falta de tempo hábil no cronograma do curso para que essas aulas fossem viabilizadas, podendo sair muito do tempo previsto na matriz curricular aprovada pelo MEC; ausência de conectividade nas comunidades e escolas para comunicação entre os sujeitos envolvidos na pesquisa; dentre alguns outros problemas locais.

Um professor que adota uma postura dialógica em relação aos recursos que utiliza sabe que, ao final de uma apresentação, ele provavelmente sentiria o impulso de modificar o que havia preparado. A reação de seus alunos gera novas ideias e a demanda de aperfeiçoamentos, inserção de novos dados, maior clareza nos argumentos, associação a outras referências 
citadas. Caso aceite fazer isso, o professor terá incorporado um pouquinho de seus alunos nesse recurso, e eles se tornam, portanto, autores indiretos do novo material (STAROBINAS, 2012, p. 125).

A discussão dos parágrafos anteriores se aplica também aos dados trazidos a seguir, que continuam a falar do uso de REA, mas acrescentando a questão da produção e adaptação desses recursos.

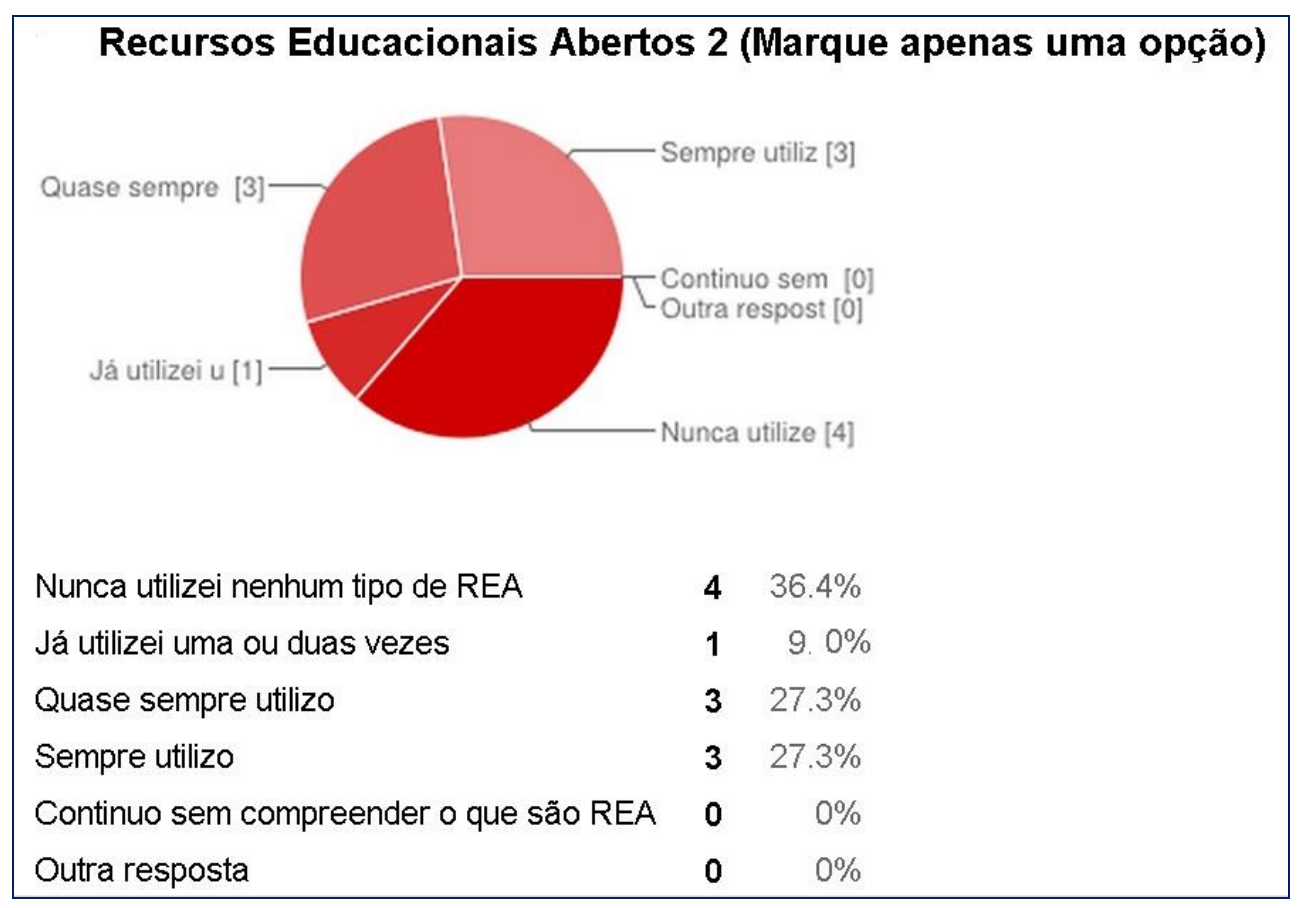

Gráfico 8: Utilização de REA nas aulas

Ao apresentarmos, mais uma vez, o conceito de REA e depois interrogarmos se eles já teriam adaptado ou produzido algum tipo de REA para utilizar nas aulas, obtivemos como resposta: 36,4\% dos entrevistados nunca adaptaram ou produziram REA para utilizar nas aulas; $27,3 \%$ já o fizeram, embora não soubessem que era um REA; 18,3\% disseram já ter adaptado ou produzido REA várias vezes; $9,0 \%$ já o fizeram algumas vezes e $9,0 \%$ disseram já ter adaptado, mas nunca produzido um REA, como mostrado no Gráfico 9. 


\section{Recursos Educacionais Abertos 4 (Marque apenas uma opção)}

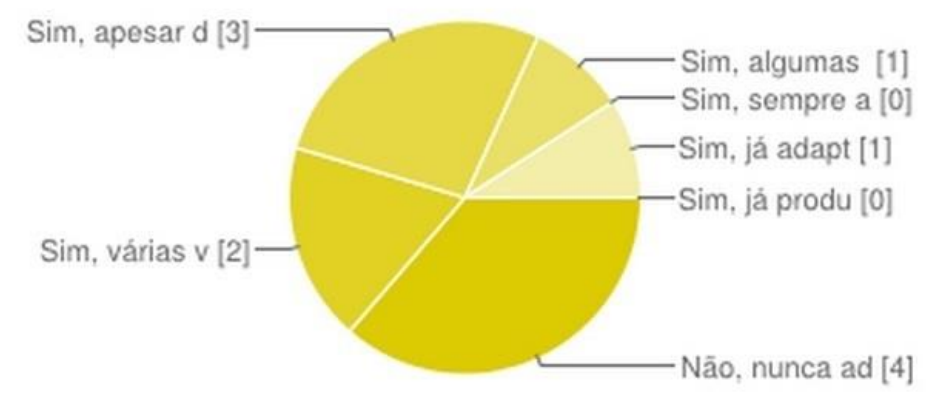

Não, nunca adaptei e nem produzi REA para utilizar nas aulas. $\quad 4 \quad 36.4 \%$

Sim, várias vezes.

$218.3 \%$

Sim, apesar de não saber que era um REA.

$327.3 \%$

Sim, algumas vezes.

$19.0 \%$

Sim, sempre adapto ou produzo REA.

$0 \quad 0 \%$

Sim, já adaptei, mas nunca produzi.

$19.0 \%$

Sim, já produzi, mas nunca adaptei.

$0 \quad 0 \%$

Gráfico 9: Produção e/ou adaptação de REA para uso em aulas

Ao apresentarmos algumas sugestões do que poderia acontecer a partir da produção e adaptação de REA para as comunidades do campo, pedimos que os entrevistados indicassem as opções de sua escolha (podendo ser quantas quisessem), ao que obtivemos como respostas: $72,7 \%$ disseram haver possibilidade de melhorar o trabalho pedagógico por poder contextualizar o trabalho realizado; $54,4 \%$ acreditam gerar a possibilidade de qualificar o trabalho pedagógico por poder utilizar REA produzidos pelos próprios educandos, com características de sua cultura; $45,5 \%$ dos entrevistados ponderam que haja possibilidade de transformar as relações educativas por quebrar a hierarquização existente entre professor e alunos, pois todos passam a poder ser autores dos materiais didáticos utilizados; $18,2 \%$ acreditam ter possibilidade de autoria própria de materiais produzidos de acordo com a cultura local, suas potencialidades e suas dificuldades; e para 9,1\% poderia gerar dificuldades diversas porque a maioria dos professores não sabe utilizar o computador, como consta do Gráfico 10. 


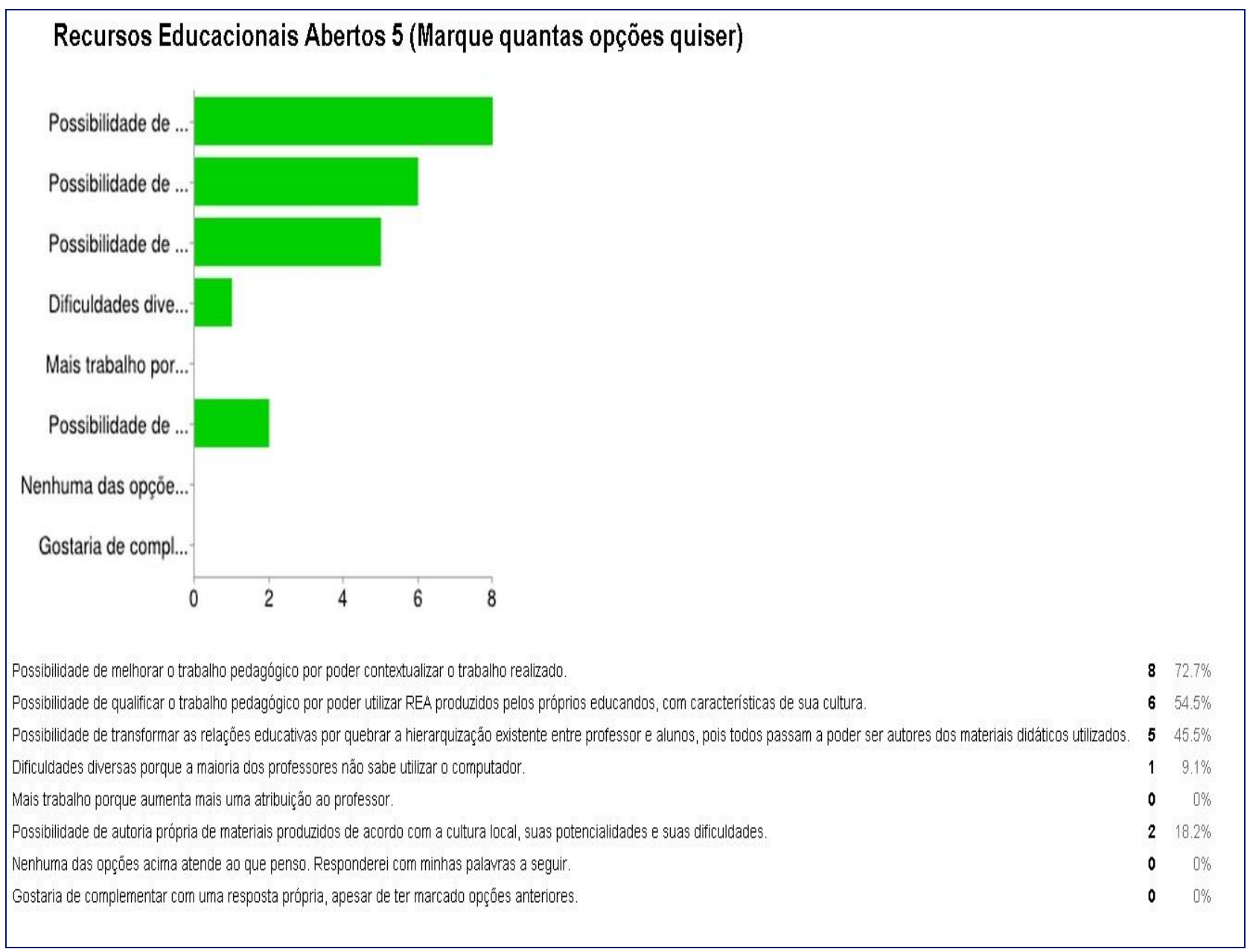

Gráfico 10: Produção de REA específico para escolas do campo

Para Starobinas (2012), produzir e adaptar REA pode qualificar muito 0 trabalho docente, bem como pode transformar o cenário de produção de materiais didáticos no Brasil no momento atual. Para ela,

O desejo de adaptação dos materiais costuma emergir em situações muito diversas. No caso do Brasil, é preciso considerar, por exemplo, que a concentração da produção de materiais didáticos em algumas regiões do país favorece a existência de distorções quanto à relevância dada a alguns temas. No caso do estudo de História, não é difícil verificar a desproporção entre uma narrativa geral focada nos grandes centros econômicos e políticos e o espaço dado à história local. Junto a isso, ainda está em curso a crítica a um texto didático que pouco espaço dá a vozes variadas do fazer social, privilegiando estereótipos consolidados numa narrativa de massa. Tomando o caso da história de São Paulo, uma região que poderia ser considerada bem atendida em termos de recursos didáticos, é gritante a desproporção que se constata entre o enaltecimento à cultura do café e seu espírito pioneiro, e o quase silêncio devotado à história da escravidão. $O$ mesmo vale para as parcas linhas que tratam dos povos indígenas, as inúmeras páginas ofertadas aos imigrantes europeus e 
asiáticos, o laconismo em relação ao migrante nordestino, entre vários outros exemplos.

Nessa direção, é preciso destacar que a inclusão dos materiais de pesquisa como recursos educacionais abertos constitui um aporte fundamental para a possibilidade de transformação desse cenário limitado dos materiais didáticos disponíveis. A pesquisa acadêmica tem se debruçado nas últimas décadas sobre muitos temas relativos ao Brasil, e o acervo de artigos e materiais de pesquisa dos grupos das universidades deveriam funcionar como um qualificado repositório de recursos passíveis de serem adaptados para usos educacionais em contextos variados (STAROBINAS, 2012, p. 124).

Por fim, questionamos se os entrevistados achavam que os Recursos Educacionais Abertos poderiam ajudar a ressignificar a prática pedagógica de educadores do campo e de que modo isso poderia acontecer. Se observarmos as respostas a seguir, $81,8 \%$ dos respondentes disseram que sim, que isso seria possível, cada um complementando à sua maneira, como vemos.

\begin{tabular}{|c|c|}
\hline Nomes fictícios: & Respostas: \\
\hline Diadorim & Sim. Acho que de uma forma bem democrática. \\
\hline Davidão & $\begin{array}{l}\text { Sim, com certeza. em primeiro lugar as comunidades } \\
\text { do campo todas precisam ter acesso a computadores } \\
\text { e a internet, senão de nada adianta essa discussão. }\end{array}$ \\
\hline Maria Leôncia & $\begin{array}{l}\text { Sim, com certeza. em primeiro lugar as comunidades } \\
\text { do campo todas precisam ter acesso a computadores } \\
\text { e a internet, senão de nada adianta essa discussão. }\end{array}$ \\
\hline Riobaldo & $\begin{array}{l}\text { A utilização de novas mídias para os educadores do } \\
\text { campo, só vem somar com o processo ensino e } \\
\text { aprendizagem, mas para que isso ocorra é preciso } \\
\text { está disponível internet de qualidade para acesso dos } \\
\text { professores. }\end{array}$ \\
\hline Medeiro Vaz & $\begin{array}{l}\text { Na medida em as experiências vão se consolidando a } \\
\text { produção do material proporciona o } \\
\text { compartilhamento do mesmo. }\end{array}$ \\
\hline Otacília & Na escola ainda não tem essa programa, \\
\hline Doutor Fausto & $\begin{array}{l}\text { Através dessa possibilidade de significar o trabalho } \\
\text { pedagógico partindo do ponto de vista da mudança } \\
\text { de concepção do uso do computador e internet no } \\
\text { processo de ensino aprendizagem. }\end{array}$ \\
\hline Joca Ramiro & $\begin{array}{l}\text { Sim. Com a possibilidade de produzir seus próprios } \\
\text { materiais. }\end{array}$ \\
\hline
\end{tabular}




\begin{tabular}{|l|l|}
\hline Nhorinhá & \\
\hline Hermógenes & $\begin{array}{l}\text { Eu acho que sim. Porque a partir do momento que } \\
\text { podemos produzir materiais a partir da realidade dos } \\
\text { educandos, fica mais fácil contextualizar, os } \\
\text { educandos passam a compreender melhor o que } \\
\text { queremos ensinar. Além disso, quem não gosta de se } \\
\text { ver sendo projetado, postado? Os educandos iriam } \\
\text { adorar ajudar a produzir os materiais. }\end{array}$ \\
\hline Zé Bebelo & $\begin{array}{l}\text { Sim. Seminário entre os educadores/as sobre as } \\
\text { praticas pedagógicas. Acompanhamento sistemático } \\
\text { sobre o desenvolvimento da aprendizagem dos } \\
\text { educandos/as }\end{array}$ \\
\hline
\end{tabular}

Tabela 8: REA nas práticas pedagógicas de educadores do campo

É interessante também perceber a qualidade das respostas dadas por alguns desses docentes, quando pensam, por exemplo, na mudança de concepção de computador e Internet no trabalho pedagógico, ou mesmo na contextualização e no compartilhamento de conteúdos.

Concluímos nossas análises sobre esse tema utilizando as palavras de Starobinas (2012) que, tão bem, retratam nosso pensamento frente à necessidade de ressignificarmos o trabalho pedagógico nas escolas do campo no Brasil.

A disseminação de uma cultura de uso de recursos educacionais abertos na educação básica passa pela inclusão dos alunos na cadeia de autoria, seja nas atividades regulares associadas ao currículo, seja estimulando iniciativas autônomas de produção de conteúdo em atividades complementares - a produção dos grêmios, os saraus literários, os festivais de bandas, os grupos de ciência, os times de modalidades esportivas diversas etc. De certa forma, seria como se a escola reconhecesse todas as experiências como válidas na trajetória de formação de seus alunos, e pudesse fazer uso dessas narrativas - vídeos, fotos, textos, sons - na documentação de seu percurso institucional (STAROBINAS, 2012, pp. 128-129). 


\section{CONCLUSÕES}

A luta pela Educação do Campo é recente na história brasileira, mas tem se constituído e se construído a partir de demandas muito legítimas das populações do campo das diversas regiões brasileiras. É com base nessas demandas que surge não só a Educação do Campo enquanto educação básica, mas também a formação superior de educadores do campo, o que modifica qualitativamente a perspectiva de uma educação para os povos do campo construída no campo, para o campo e do campo.

Durante muito tempo a educação ofertada nas escolas rurais era um "arremedo" de educação urbana, só que com muito menos a oferecer a essas populações. Se hoje temos uma Educação DO Campo, pensada a partir das demandas dos povos do campo juntamente com eles, é porque os movimentos sociais do campo têm lutado pela garantia desse e de outros direitos fundamentais para essas populações historicamente excluídas das políticas públicas em todos os sentidos.

A Licenciatura em Educação do Campo foi uma grande vitória, em termos de política de formação de educadores, para os povos do campo, pois garantem que os educadores de suas comunidades possam se formar e continuar educando em seus territórios, onde forjam suas vidas, onde produzem, onde constroem suas culturas. Com isso, também é garantida a atuação, nas escolas do campo, de educadores que conhecem e compartilham a realidade de seus educandos, que vivenciam as mesmas problemáticas e que podem falar do mesmo lugar que eles. Garantem, também, que esses educadores, depois de formados, queiram retornar às suas comunidades e proporcionar a elas algo melhor, uma educação da qualidade que elas merecem e com tudo aquilo que as forjou sendo valorizado e garantido nos seus currículos e práticas.

Formar um educador do campo requer diferenciação no tratamento, no currículo, nas estratégias e nas práticas pedagógicas. Na formação de educadores do campo faz-se necessário entender o que é o campo brasileiro, quais suas especificidades e lutas, o que é a Educação do Campo e qual seu histórico. De preferência, a formadora e o formador de educadores do campo precisam fazer uma imersão em comunidades campesinas, em escolas do 
campo, para entender sua dinâmica e seus processos, para, só então, ver o que têm e se têm algo a contribuir com essa formação em suas especificidades. Assim, Castro e Ferreira nos confirmam isso com as ideias de Arroyo quando dizem que,

Miguel Arroyo, então, entende que a formação do educador do campo precisa ter como matriz a compreensão da força destes elementos: território, terra, socialização, política, cultura, identidade dos povos do campo, comunidade; sem isso não se poderá tornar a escola um lócus de formação. Para que isto aconteça, uma primeira estratégia que Arroyo vê como essencial e que já tem sido utilizada é a de ocupar os espaços e programas já instituídos. Esta ocupação vem criando a consciência de que a especificidade na formação de educadores e educadoras do campo não é mais para ser questionada, mas garantida (CASTRO \& FERREIRA, 2013, p. 165).

Apesar de as Licenciaturas em Educação do Campo, as Pedagogias da Terra, os cursos do PRONERA e outras políticas de formação do povo campesino estarem se espalhando pelo país, ainda não atendem a toda demanda existente devido à extensão geográfica do Brasil. Boa parte dessa população menos favorecida ainda prescinde de uma formação de nível superior por falta de recursos e por problemas de logística. Outra parte da população do campo tem se esforçado para terminar uma formação em instituições particulares, presenciais ou a distância, mas que em nada atendem às especificidades e às necessidades de formação dessa enorme parcela população brasileira. Essas são contradições importantes que nos aparecem nas discussões realizadas nas aulas da LEdoC e, mais especificamente, no componente Comunicação e Tecnologias da Informação.

Contudo, o ideal seria mesmo a formação dos sujeitos do campo em suas comunidades, com professores locais bem formados, trabalhando com elementos da cultura local aliada à cultura universal, de modo que eles pudessem construir seus próprios percursos formativos a partir de suas necessidades e anseios. Formações que valorizassem seus contextos locais e regionais e que mostrassem a esses estudantes o quanto seria bom que eles se formassem e se vinculassem a seus territórios de origem, levando trabalho qualificado e, ao mesmo tempo tendo como sobreviver a partir de seu próprio trabalho e de suas terras e produções. 
Dentro da perspectiva do Materialismo Histórico Dialético é imprescindível que o conhecimento crítico sirva para produzir práticas sociais que alterem e transformem a realidade anterior no plano do conhecimento e no plano histórico-social. Então, ao concluir esta etapa desta pesquisa nos perguntamos: isso aconteceu com os sujeitos envolvidos? Gerou alguma transformação social nas comunidades em que esses sujeitos nutrem suas vidas e constroem sua docência? Foi por meio da práxis que essa investigação se concretizou, ou seja, fizemos o movimento dialógico entre teoria e prática, ação-reflexão-ação, como deveria ser para gerar transformação crítica? Podemos responder a essas questões afirmativamente, pois houve e continua a haver transformação social tanto na vida desses sujeitos, docentes agora formados, e também nas comunidades campesinas das quais eles fazem parte e na qual replicam criticamente as práticas sociais com consciência e materialidade.

Isso foi possível devido a todo processo relativo à construção de uma Educação do Campo contextualizada, crítica, questionadora, baseada nas próprias contradições, em seus próprios conflitos e em sua superação, nas questões locais, mas também naquelas relativas ao universal.

Entretanto, esses resultados também foram possíveis devido a um componente curricular que se propôs a discutir a realidade do processo educativo e capaz de testar novas estratégias pedagógicas no sentido da contra-hegemonia, da emancipação, da construção de novos rumos para a educação do campo e para um projeto de sociedade diferente do que está estabelecido. Comunicação e Tecnologias da Informação, enquanto pesquisa, desenvolveu-se a partir das seguintes ações:

I. Aplicação de questionário diagnóstico sobre a disponibilidade e acesso dos docentes em formação no que diz respeito aos recursos de Tecnologias Digitais com ênfase em computadores e Internet.

II. Utilização de textos, ideias, imagens, conceitos para realização de reflexões que favorecessem o conhecimento crítico sobre os movimentos da sociedade (chamados de "conceitos permeadores" cuja finalidade foi trabalhar uma concepção de 
sociedade com a centralidade no trabalho). Em nossas ações em CTI adotamos uma estratégia para dar um suporte teórico geral (que chamamos de fio condutor) que consistia em oferecer textos, ideias, conceitos com a intenção declarada de que os docentes em formação pautassem suas práticas educativas inerentes aos conteúdos e suas reflexões por uma explicaçãojustificativa-associação crítica prévia. Isso acontecia no início de cada aula e era reforçado de tempos em tempos no decurso de nossos diálogos pedagógicos.

III. Aulas práticas sobre a utilização do computador, seus aplicativos e programas diversos em sua prática discente e também para a prática docente com observação e anotações sobre 0 desempenho dos docentes em formação, assim como sobre as discussões paralelas que surgiam nesse interim.

IV. Aulas teóricas em que, além dos conceitos permeadores, foram discutidas formas de utilização de Tecnologias Digitais no apoio ao trabalho pedagógico.

V. Aulas práticas sobre a produção e publicação de materiais didáticos digitais, também chamados de Objetos de Aprendizagem e que, nesta pesquisa são classificados como Recursos Educacionais Abertos, dadas suas características de produção, compartilhamento e possibilidade de edição por outrem.

VI. Reflexões e discussões sobre as práticas realizadas tanto no aprendizado instrumental do computador e da Internet, como sobre as práticas de produção, autoria e compartilhamento feitas no Tempo Comunidade com seus pares e relatadas no retorno ao Tempo Escola.

VII. Práticas de utilização do Ambiente Virtual de Aprendizagem Moodle, seja para aprender a utilizá-lo como discente, como também para sua utilização em complementariedade à prática docente.

VIII. Aplicação de entrevista estruturada por meio de questionário digital online para conhecer a realidade desses, agora, egressos 
e a aplicação dos conhecimentos construídos em CTI nas escolas em que trabalham atualmente.

A utilização de Recursos Educacionais Abertos, bem como da Educação Aberta, ampliam muito as possibilidades de formação dos sujeitos, é tendência mundial. Já não há como retroceder nesse caminho. O sistema capitalista ainda não conseguiu mecanismos para impedir que essa ideia e sua materialização se disseminem, o que promove a quebra de muitos multimilionários que lucram com a produção e venda de materiais didáticos, digitais ou não, que além da mais valia, têm como objetivo fundamental continuar formando para a alienação e para a reprodução.

As contradições existentes na relação do campo com as Tecnologias Digitais são muitas, mas contradições e conflitos servem para solucionar as questões relativas a vida e trabalho. Sem os conflitos não saímos da mesmice, da situação de opressão. São eles que nos motivam e nos movem.

Ainda são poucos os cursos de formação docente que trabalham com as Tecnologias Digitais na organização do trabalho pedagógico. É preciso mudanças também nos currículos desses cursos de modo a contemplar essa necessidade.

O uso de Tecnologias Digitais e REA, em si, não promove transformação nas práticas pedagógicas, essa transformação somente acontecerá a partir de um conjunto de situações que tenham essa mudança como um de seus objetivos. Esse conjunto de situações envolve abertura para novas práticas; constante movimento de formação pedagógica por parte da equipe profissional envolvida; busca pelo aprendizado e apropriação de novas estratégias e técnicas de produção de REA; trabalho conjunto da equipe docente em busca de objetivos comuns; revisão constante do Projeto Político Pedagógico da unidade de ensino, de modo a sempre contextualizar e adequar as áreas do conhecimento e dimensões humanas a serem trabalhadas; por fim, promover um movimento de análise de conjuntura e idas e vindas na busca pelas melhores soluções para os conflitos e contradições que surgem no cotidiano, seja da escola, seja da comunidade. 
Com esta pesquisa pudemos constatar que, ao ingressar na LEdoC os docentes em formação, em sua quase totalidade, não tinham conhecimentos informáticos básicos e puderam construí-los ao longo do curso tanto nas aulas de Comunicação e Tecnologias da Informação quanto nos demais componentes curriculares.

Esse estudo nos mostrou, também, o quão deficientes estamos em relação à necessidade reformulação de nossos currículos e de transformação de nossas práticas pedagógicas. Mesmo sendo uma investigação apenas inicial, pudemos constatar que as Tecnologias Digitais fizeram diferença nas situações educativas escolares, levando melhorias no sentido da relação educando-educador e também no sentido educando-conhecimento.

Outro aspecto que ficou evidente foi o de que as Tecnologias Digitais auxiliam os educadores em seu trabalho docente desde o momento da coordenação, incluindo aí o planejamento e a busca por materiais didáticos adequados para as aulas.

Finalmente, concluímos que apesar de não saberem denominar os Recursos Educacionais Abertos, os docentes egressos da LEdoC-UnB Turma 2 já fazem uso dos mesmos, com certa frequência, em suas aulas em escolas do campo. E que esse uso proporciona melhoria na qualidade do trabalho pedagógico e no aprendizado dos educandos.

Assim, o objetivo inicial dessa pesquisa que era investigar se a produção e utilização de Recursos Educacionais contextualizados por educadores do campo em formação poderiam provocar alterações, numa perspectiva transformadora/emancipadora, em suas práticas pedagógicas de educadores nas escolas do campo, além de ser alcançado, ainda nos permitiu ampliar o escopo da pesquisa para utilização e produção de Recursos Educacionais Abertos, o que complementa nossa ideia de prática emancipatória por não utilizar programas e aplicativos pagos e compartilhar materiais que podem auxiliar outros educadores do campo.

\section{CONSIDERAÇÕES FINAIS E RECOMENDAÇÕES}

O que restou como pista de pesquisa para que investiguemos futuramente foi se a produção de Recursos Educacionais Abertos pelos 
docentes e educandos com os quais trabalham pode ajudar a ressignificar os currículos das escolas do campo, já que há grande necessidade que essa reformulação seja feita. Convidamos aos colegas de área a realizarmos essa investigação juntos.

Pelo resultado desta investigação, chegamos à conclusão que esta área de conhecimento é muito importante para os educadores do campo, pois ela proporciona a esses sujeitos conhecimentos que Ihes são historicamente negados e que são de extrema importância para sua atuação nas escolas do campo, mas também, e principalmente, para suas comunidades e 0 desenvolvimento local.

É preciso fortalecer esta área de conhecimento na Licenciatura em Educação do Campo da UnB! E acreditamos que esse fortalecimento passa por um conjunto de ações em que estariam contempladas: criação do componente curricular Letramento Científico e Digital como disciplina e não mais oficina; abertura de concurso para docente com vaga específica para esta área de conhecimento; ampliação da carga horária do componente na matriz e no Projeto Político Pedagógico desta Licenciatura; criação de vaga para monitor da disciplina com formação específica; construção e dotação de infraestrutura de pelo menos dois laboratórios de informática exclusivos para a LEdoC com manutenção periódica; contratação de serviço de Internet de boa qualidade/velocidade para ambos os laboratórios.

Esclarecendo cada uma dessas sugestões:

$\checkmark$ criação do componente curricular Letramento Científico e Digital como disciplina e não mais oficina - a ideia é que esse componente curricular perpasse todos os semestres letivos do curso e que atenda também às necessidades de formação da área de conhecimento de opção do estudante, proporcionandoIhes informações e construção de conhecimentos importantes para sua área de conhecimento e para sua prática pedagógica no campo, como acontece na LEdoC-UFBA;

$\checkmark$ ampliação da carga horária do componente na matriz e no Projeto Político Pedagógico desta Licenciatura - assim como acontece na UFBA, é importante que o componente Letramento 
Científico e Digital perpasse todos os semestres, de modo que possa contemplar as necessidades de formação para produção de materiais para a área de conhecimento de opção do estudante. Dessa forma, seria possível realizar uma formação pedagógica e tecnológica capaz de proporcionar autonomia intelectual aos educadores do campo formados pela LEdoCUnB;

$\checkmark$ abertura de concurso para docente com duas ou mais vagas específica para esta área de conhecimento dentro da LEdoC se a ideia é que o componente Letramento Científico e Digital perpasse todo o curso, será necessário mais de um docente para suprir as necessidades das várias turmas e também das áreas de conhecimento. Hoje existem dois docentes voluntários atuando no componente e que por necessidades pessoais podem não dar continuidade ao trabalho a qualquer momento, já que não têm vínculo empregatício com a UnB e precisam trabalhar em outro emprego para se manterem. Com a abertura das vagas e o concurso esses docentes poderiam se vincular à universidade resolvendo esse problema;

$\checkmark$ criação de vaga para monitor/estagiário da disciplina com formação específica - um docente para atender a uma turma de 40 a 60 estudantes é inviável, pois o trabalho se assemelha ao trabalho de alfabetização, dada a ausência de conhecimentos desses sujeitos sobre o uso técnico de computador e Internet. $O$ monitor ou estagiário é um auxiliar do docente para atendimento individualizado às dúvidas de cada estudante, seja quanto aos primeiros contatos com essas tecnologias, seja nos demais momentos de formação;

construção e dotação de infraestrutura de pelo menos dois laboratórios de informática exclusivos para a LEdoC com manutenção periódica - os laboratórios existentes atualmente não atendem às necessidades dos cursos e turmas atuais e não atenderiam à necessidade relativa ao aumento da carga horária do componente para várias turmas da Licenciatura em 
andamento. Além disso, são necessários computadores de mesma configuração e com os mesmos softwares instalados para atendimento de turmas tão numerosas;

$\checkmark$ contratação de serviço de Internet de boa qualidade/velocidade para ambos os laboratórios - a Internet disponibilizada atualmente não atende às demandas de todo o Campus Planaltina, então, não atenderia um aumento dessa demanda. Além disso, seria necessária uma Internet com velocidade maior para melhor aproveitamento do tempo dos estudantes em seu período de Tempo Escola.

Para o componente curricular sugerido, teríamos uma ementa diferenciada a cada semestre ou Tempo Escola, já que a ideia seria perpassar todo o curso. No entanto, poderíamos sugerir uma ementa maior abrangendo as bases gerais dos conhecimentos e informações a serem desenvolvidos durante o curso. Essa ementa seria: Ciência, Tecnologia e Sociedade - CTS. CTS e tratamento das inter-relações entre explicação científica, planejamento tecnológico e solução de problemas, e tomada de decisões sobre temas práticos de importância social. Aprendizado colaborativo/cooperativo. Aspectos centrais da prática tecnológica: técnico, organizacional e cultural. Tecnologias sociais. Comunicação e sociedade. Tecnologias de Informação e Comunicação. Abordagem pedagógica das Tecnologias Digitais. Recursos Educacionais Abertos - REA. Repositórios institucionais de Objetos de Aprendizagem. Ambientes Virtuais de Aprendizagem. Redes Sociais de Aprendizagem. Educação e Internet: possibilidades e limites.

A intencionalidade pedagógica, ao sugerirmos esse componente curricular, é de promover um letramento que a escola rural não propiciou a esses educadores do campo enquanto estudantes. Como nos diz Néder,

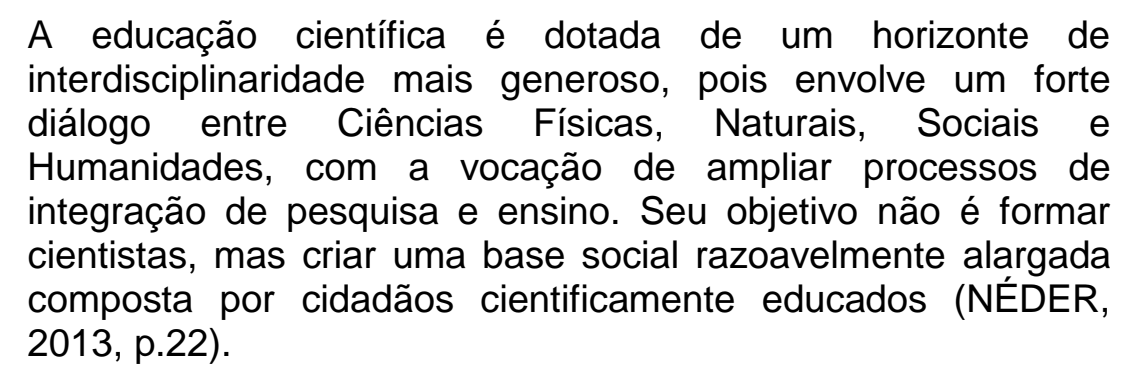

A educação científica é dotada de um horizonte de interdisciplinaridade mais generoso, pois envolve um forte diálogo entre Ciências Físicas, Naturais, Sociais e Humanidades, com a vocação de ampliar processos de integração de pesquisa e ensino. Seu objetivo não é formar cientistas, mas criar uma base social razoavelmente alargada 2013, p.22). 
Falar desse Letramento é falar sobre a autonomia intelectual, algo que também conseguimos observar a partir do trabalho realizado em CTI e que proporcionou aos sujeitos em formação, juntamente com os demais componentes curriculares, aprendizagens que não estão nos currículos, formas e locais de se pesquisar o que se deseja; possibilidade de autoria e de publicização de seus produtos intelectuais.

Acreditamos, a partir dessa pesquisa, que à medida que as pessoas passam por um processo de autoconhecimento e passam a utilizar as Tecnologias Digitais com êxito, elas se emancipam. Elas são capazes de mobilizar seus pares e iniciar processos emancipatórios também.

Nesse período muitas relações foram iniciadas e consolidadas e isso foi crucial para o processo de formação desses sujeitos. Além das amizades que nasceram e que permanecem, esses educadores nos veem como mediadores e uma espécie de padrinhos de seus processos de crescimento pessoal e profissional e nos buscam sempre que acham necessário, seja para contarem suas conquistas e vitórias, seja para pedir ajudar na hora da dúvida.

Foi também nesse processo de autoconhecimento, politização e discussão de conceitos permeadores que buscamos superar os fetiches e os medos das Tecnologias Digitais que esses sujeitos traziam de suas comunidades e escolas, onde, normalmente, estavam acostumados a ouvir e reproduzir o discurso da classe dominante que diz que o campo e os sujeitos do campo não precisam de Tecnologias Digitais de comunicação.

A partir do trabalho desenvolvido durante esses quatro anos, pudemos perceber os educadores do campo em formação galgarem diferentes níveis de consciência em relação às Tecnologias Digitais, abandonando esse discurso derrotista para se perceberem sujeitos de direitos dessas Tecnologias, se apropriarem delas, das práticas pedagógicas utilizando-as e do discurso afirmativo que coloca as Tecnologias Digitais como um patrimônio da humanidade que pode ser transformado para promover ações contrahegemônicas.

As transformações ocorridas na vida desses sujeitos, de suas comunidades e escolas onde atuam a partir de seu ingresso na LEdoC e e 
também das aulas de Comunicação e Tecnologias da Informação. Um exemplo disso é que hoje em dia, todas as comunidades que têm estudantes da Licenciatura em Educação do Campo contam com computador e Internet ou pelo menos sabem da importância desses para a comunidade do campo.

Além disso, em várias comunidades com estudantes frequentando a LEdoC-UnB conseguiram instalar uma Casa Digital na comunidade, o que facilita a comunicação da comunidade com o mundo, além de dar um suporte ao trabalho dos educadores das escolas vizinhas.

Outro ponto de importância fundamental na vida desses educadores é que eles estão dando continuidade aos seus estudos e à sua vida acadêmica. Muitos já estão terminando cursos de pós-graduação latu senso oferecidos pela própria UnB ou por outras instituições e outros voaram mais longe e fizeram processo seletivo para pós graduação stricto senso e estão cursando o mestrado em Educação Ambiental e Educação do Campo da UnB.

O trabalho no componente curricular Comunicação e Tecnologias da Informação continua a ser realizado nas demais turmas subsequentes, apesar de ainda não contar com professores efetivos. Imaginamos que, futuramente os estudantes possam contar com professores efetivos, que se dediquem exclusivamente a pesquisa, ensino e extensão voltados à LEdoC e às comunidades campesinas.

Os sujeitos do campo também têm direito à produção do conhecimento e divulgação de sua produção. Não é possível que continuemos com as práticas reproduzidas ao longo da história, no sentido de apenas acreditar que só existe conhecimento científico e que os sujeitos externos à academia não são capazes de produzi-lo. Negar esse direito é negar a história de grande parte da população brasileira. Somos sujeitos de cultura eminentemente rural porque nossos ancestrais viveram no campo e construíram ali sua cultura, sua religião, sua história, as quais herdamos e nas quais também temos parte.

As escolas do campo têm direito a construir seus próprios currículos e suas próprias práticas a partir da realidade em que estão inseridas e também daquilo que foi historicamente construído pela humanidade. Não se pode mais negar a essas escolas e aos sujeitos que as constroem o direito a pensar sua 
educação e a executar práticas a partir de suas próprias elaborações teóricas, epistemológicas, culturais, científicas, religiosas. Enfim, é preciso dar o espaço que a educação do campo necessita para se edificar enquanto possibilidade e espaço de produção de vida e de história. 


\section{REFERÊNCIAS}

ADORNO, Theodor W. Educação e Emancipação. Trad. Wolfgang Leo Maar. Rio de Janeiro: Paz e Terra, 1995.

ALMEIDA, Maria Elisabeth Bianconcini de. Inclusão digital de professor: Formação e prática pedagógica. São Paulo: Editora Articulação Universidade/Escola, 2004.

ALVES-MAZZOTTI, A.J.; GEWANDSZNAJDER, F. 0 método nas ciências sociais: pesquisa quantitativa e qualitativa. $2^{\mathrm{a}} e d$. São Paulo: Pioneira Thomson Learning, 2004.

AMIEL, Tel; PRETTO, Nelson Lucca.; INUZUKA, Marcelo Akira; LIMA, Priscila da S. Neves. Curso REA: a construção de um curso aberto apoiado por software livre de mídias sociais. In: ERI-GO 2014 - II Escola Regional de Informática de Goiás. Disponível em http://www.livrorea.net.br/livro/home.html Acesso em fev/2015.

ANASTASIOU, Léa das G. C. A função pedagógica da coordenação de curso de graduação. In: ISAIA, S.M. de A; BOLZAN, D. P.de V. (Orgs.) Pedagogia universitária e desenvolvimento profissional docente. Porto Alegre: EDIPUCRS, 2009.

ANTONIO, C. A. (Org.); ALMEIDA, Benedita de (Org.); ZANELLA, José Luiz (Org.). Educação do Campo: um projeto de formação de educadores em debate. 1. ed. Cascavel/PR: Edunioeste, 2008. v.500. 148p.

ANTONIO, C. A. O currículo em escolas do campo: projetos políticopedagógicos em construção. In: Benedita de Almeida; Mafalda Nesi Francischett; Yolanda Zancalella. (Org.). In: Experiências Educativas em Formação de Professores: pesquisas e trajetórias. 1ed.Cascavel/PR: Edunioeste, 2009, v. 1, p. 121-143.

ANTONIO, C. A.; ALMEIDA, Benedita de; ZANCANELLA, Yolanda; FRANCISCHETT, Mafalda Nesi; PEDROSO, André Pereira. Educação do Campo: Práticas Educativas em Escolas e Formação de Educadores no Sudoeste. 2012.

ANTONIO, C. A.; RIOS, Anikeli. Orientações Formativas e Didático-Curriculares por Complexos de Estudos: Pesquisando Fundamentos Pedagógicos para a Educação do Campo. In: IV Seminário Nacional Interdisciplinar em Experiências Educativas - IV SENIEE, 2012, Francisco Beltrão - PR. Anais IV Seminário Nacional Interdisciplinar em Experiências Educativas - IV SENIEE. Francisco Beltrão: Unioeste - Francisco Beltrão, 2012. v.1, p. 950-965.

ANTONIO, C. A.; SAPELLI; GHERK. Currículo e escola itinerante: pressupostos, conteúdo, vivências geradoras e avaliação. In: Marlene Lucia Siebert Sapelli. (Org.). Vozes de resistência: sobre práticas educativas nos tempos e espaços ocupados pelo MST. Guarapuava/PR: 2010, v. 01, p.1566.

ANTONIO, Clésio Acilino. O currículo e escolas do campo: questões políticopedagógicas em superação. Revista do Centro de Educação, UFSM, Santa Maria, RS. Edição: 2008 - Vol. 33 - No. 01. Disponível em http://coralx.ufsm.br/revce/revce/2008/01/a5.htm <Acesso em jan/2013> 
ANTONIO, Clésio Acilino; ALMEIDA, Benedita de; FRANCISCHETT, Mafalda N.; Pedroso, GHEDINI (Orgs.). Educação do Campo, Formação Continuada e Práticas Curriculares em Construção. 1. ed. Francisco Beltrão/PR: UNIOESTE, Campus de Francisco Beltrão, 2010. v. 200. 65p.

ARROYO, Miguel Gonzalez. A Educação Básica e o Movimento Social do Campo. In: ARROYO, Miguel Gonzalez; CALDART, Roseli Salete; MOLINA, Mônica Castagna (orgs.). Por uma educação básica do campo. Petrópolis, RJ: Vozes, 2004a.

ARROYO, Miguel Gonzalez. Currículo, território em disputa. Petrópolis, RJ: Vozes, 2011.

ARROYO, Miguel Gonzalez. Imagens quebradas: trajetórias e tempos de alunos e mestres. Petrópolis, RJ: Vozes, 2004b.

ARROYO, Miguel Gonzalez. Ofício de mestre: imagens e autoimagens. Petrópolis, RJ: Vozes, 2010.

ARROYO, Miguel Gonzalez. Outros sujeitos, outras pedagogias. Petrópolis, RJ: Vozes, 2012.

ARROYO, Miguel Gonzalez. Por um tratamento público da Educação do Campo. In: Contribuições para a construção de um Projeto de Educação do Campo. Brasília - DF, Articulação Nacional Por uma Educação do Campo, 2004.

ARROYO, Miguel Gonzalez; CALDART, Roseli Salete; MOLINA, Mônica Castagna (orgs.). Por uma educação do campo. Petrópolis: Vozes, 2004.

ARROYO, Miguel Gonzalez; NOGUEIRA, Paulo Henrique de Queiroz (org.); MIRANDA, Shirley Aparecida de (org.). Miguel Arroyo: educador em diálogo com nosso tempo. Belo Horizonte, MG: Autêntica Editora, 2011.

AUED, Bernadete Wrublevski; VENDRAMINI, Célia Regina (orgs.). Educação do campo: desafios teóricos e práticos. Florianópolis: Insular, 2009.

BARBIER, René. A pesquisa-ação. Brasília - DF: Liber Livro Editora, 2004.

BARBIER, René. A escuta sensível em educação. Cadernos ANPED, ํo 05, UFMG, 1993. Pp. 187-216.

BARBOSA, Anna Izabel Costa. A organização do trabalho pedagógico na Licenciatura em Educação do Campo/UnB: do projeto às emergências e tramas do caminhar. Tese de Doutorado. Faculdade de Educação. Universidade de Brasília. Brasília, 2012.

BARDIN, L. Análise de conteúdo. Tradução de L.A. Antero e A. Pinheiro. Lisboa: Edições 70, 1995.

BEHRENS, M.A. Novas tecnologias e mediação pedagógica. MASETTO, M.T. Mediação pedagógica e o uso da tecnologia. In: MORAN, J.M.; MASETTO, M.T.; BEHRENS, M.A. Novas tecnologias e mediação pedagógica. Campinas, SP: Papirus, 2004.

BONILLA, Maria Helena Silveira; HALMANN, Adriane Lizbehd. Formação de professores do campo e tecnologias digitais: articulações que apontam para outras dinâmicas pedagógicas e potencializam transformações da realidade. Inter-Ação, Goiânia, v. 36, n. 1, p. 285-308, jan./jun. 2011. 
Disponível em

https://www.revistas.ufg.br/index.php/interacao/article/view/15041 Acesso em dez/2014.

BONILLA, Maria Helena. Escola aprendente: para além da Sociedade da Informação. Rio de Janeiro: Quartet, 2005.

BRASIL. MINISTÉRIO DA EDUCAÇÃO (MEC) CONSELHO NACIONAL DE EDUCAÇÃO (CNE). Resolução CNE/CEB n¹, de 3 de abril de 2002: institui diretrizes operacionais para a educação básica nas escolas do campo. Diário Oficial da União, 9 abr. 2002.

BRASIL. PRESIDÊNCIA DA REPÚBLICA. Decreto nำ 7.352, de 4 de novembro de 2010: dispõe sobre a Política Nacional de Educação do Campo e sobre o Programa Nacional na Reforma Agrária. Diário Oficial da União, 5 nov. 2010.

BUTTIGIEG, Joseph A. Educação e hegemonia. In: COUTINHO, Carlos Nelson; TEIXEIRA, Andréa de Paula. (orgs.) Ler Gramsci, entender a realidade. Rio de Janeiro: Civilização Brasileira, 2003. p. 39-50.

BUZATO. Marcelo El Khouri. Letramentos Digitais e Formação de Professores. Disponível em:

http://www.unilago.com.br/arquivosdst/24983MarceloBuzato\%20-

\%20letramento\%20digital\%20e\%20formacao\%20de\%20profs\%20@.pdf

Acesso em jan/2015.

CALDART, Roseli Salete (org.). Caminhos para transformação da escola: reflexões desde práticas da licenciatura em educação do campo. São Paulo: Expressão Popular, 2010.

CALDART, Roseli Salete. A Educação do Campo e a perspectiva de transformação da forma escolar. In: MUNARIM, Antônio; BELTRAME, Sônia; CONTE, Soraya Franzoni; PEIXER, Zilma Isabel (orgs.). Educação do campo: reflexões e perspectivas. Florianópolis: Insular, 2.ed. rev., 2011. pp. 145-187.

CALDART, Roseli Salete. A Escola do Campo em movimento - Coletivo Nacional de Educação do MST e Instituto Técnico de Capacitação e Pesquisa da Reforma Agrária (ITERRA). In: Currículo sem Fronteiras, v.3, n.1, pp. 6081, Jan/Jun 2003.

CALDART, Roseli Salete. A escola do campo em movimento. In. ARROYO, Miguel Gonzalez; CALDART, Roseli Salete; MOLINA, Mônica Castagna (orgs), Por uma educação do campo. Petrópolis: Vozes, 2004.

CALDART, Roseli Salete. Educação do Campo. In: CALDART, Roseli Salete; PEREIRA, Isabel Brasil; ALENTEJANO, Paulo \& FRIGOTTO, Gaudêncio (orgs.). Dicionário da Educação do Campo. Rio de Janeiro, São Paulo: Escola Politécnica de Saúde Joaquim Venâncio, Expressão Popular, 2012; pp. 257-265.

CALDART, Roseli Salete. Educação do campo: notas para uma análise de percurso. Trab. Educ. Saúde, Rio de Janeiro, v. 7 n. 1, p. 35-64, mar./jun.2009. Disponível em http://www.revista.epsjv.fiocruz.br/upload/revistas/r235.pdf Acesso em maio/2013.

CALDART, Roseli Salete. Pedagogia do Movimento Sem Terra. São Paulo: Expressão Popular, 2004. 
CASTRO, Wanessa de. A formação de educadores do campo para uso das tecnologias digitais na educação na LEdoC-UnB. In: 3o Simpósio Hipertexto e Tecnologias na Educação, 2010, Recife. Anais Eletrônicos. Recife: NEHTE/UFPE, 2010.2 Disponível em https://www.ufpe.br/nehte/simposio/anais/Anais-Hipertexto-2010/Wanessa-de-

Castro.pdf Acesso em abril/2012.

CASTRO, Wanessa de. A pedagogia de projetos como estratégia para a formação de professores para uso do computador na educação. Dissertação de Mestrado, Faculdade de Educação, Universidade de Brasília, 2008.

CASTRO, Wanessa de. Pedagogia de projetos em educação mediada por computador. Revista UNOPAR Científica Ciências Humanas e Educação, Londrina, v. 8, n. 1, p. 89-98, jun. 2007. Disponível em $<$ http://www12.unopar.br/unopar/pesquisa/rcArtigos.action> Acesso em jul/2010.

CASTRO, Wanessa de; FERREIRA, Márcio. Comunicação e tecnologias da informação no contexto da educação do campo. In: V Colóquio Internacional Educação e Contemporaneidade, 2011, São Cristóvão - SE. CD de Anais Completos do V Colóquio Internacional, 2011. Disponível em http://educonse.com.br/2011/cdroom/eixo\%208/conteudo.htm Acesso em abril/2012.

CASTRO, Wanessa de; FERREIRA, Márcio. Miguel Arroyo: por uma educação centrada no homem e nos coletivos. In: CUNHA, Célio da; SILVA, Maria Abádia da. (Org.). Pensamento pedagógico e políticas de Educação. 1ed.Brasília: Liber Livro, 2013, p. 159-175.

COUTINHO, Carlos Nelson; TEIXEIRA, Andréa de Paula. (orgs.) Ler Gramsci, entender a realidade. Rio de Janeiro: Civilização Brasileira, 2003. p. 39-50.

CUNHA, Célio da; SOUSA, José Vieira de; SILVA, Maria Abádia da (orgs.). 0 método dialético na pesquisa em educação. Campinas, SP: Autores Associados/Brasília, DF: Faculdade de Educação, Universidade de Brasília, UnB, 2014. pp.263-290.

DAMO, Andreisa; SIMÕES, Christian da Silva; MOURA, Danieli Veleda; MINASI, Luís Fernando; CRUZ, Ricardo Gauterio. Paulo Freire, um educador ambiental: apontamentos críticos sobre a educação ambiental a partir do pensamento freireano. In: DELOS es una revista académica de debate sobre el Desarrollo Local Sostenible. Grupo Eumed.net y Red Académica Iberoamericana Local Global, Vol. 5, № 13 (febrero 2012). Disponível em: http://www.eumed.net/rev/delos/13/dsmmc.html Acesso em out/2014.

DUTRA, Renato Luís de Souza; TAROUCO, Liane Margarida Rockenbach. Recursos Educacionais Abertos (Open Educational Resources). S/D. Disponível em http://www.cinted.ufrgs.br/ciclo9/artigos/4fRenato.pdf Acesso em jan/2015.

Educação Aberta. (2012). O que é REA. Recursos Educacionais Abertos (REA): Um caderno para professores. Campinas, SP. Disponível em: http://www.educacaoaberta.org/wiki Acesso em ago/2014.

FAGUNDES, L. O professor deve tornar-se um construtor de inovações. 
s/d.

Disponível

em:

http://www.midiativa.tv/index.php/educadores/layout/set/print/content/view/full/1

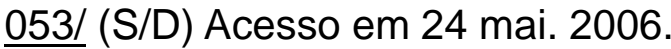

FAZENDA, Ivani (org.). Metodologia da pesquisa educacional. São Paulo: Cortez, 2010.

FERNANDES, Rosana C. de A. Coordenação de curso de graduação: das políticas públicas à gestão educacional. Tese de Doutorado. Universidade de Brasília. Brasília, 2012.

FERREIRA, Márcio. Comunicação e Tecnologias da Informação na formação de educadores para ampliação das perspectivas críticas dos sujeitos na Licenciatura em Educação do Campo da UnB. Tese de Doutorado. Faculdade de Educação, Universidade de Brasília, 2014.

FERREIRA, Márcio. Territórios Digitais: uma experiência de inclusão digital no campo brasileiro. NEAD/SDT/MDA, IICA. Brasília: IICA, 2013.

FERREIRA, Márcio; CASTRO, Wanessa de. Desafios da inclusão digital na formação docente da educação do campo. In: V Colóquio Internacional Educação e Contemporaneidade, 2011, São Cristóvão - SE. CD de Anais Completos do $\mathrm{V}$ Colóquio Internacional, 2011. Disponível em http://educonse.com.br/2011/cdroom/eixo\%208/conteudo.htm Acesso em abril/2012.

FERREIRA, Márcio; CASTRO, Wanessa de; LACERDA SANTOS, Gilberto . A pedagogia de projetos como estratégia de inclusão digital de professores dos anos iniciais do ensino fundamental. In: FERREIRA, Carlos Alberto Rosa. \& LACERDA SANTOS, Gilberto (Orgs.). A Inclusão Digital e Meios de Ensino Formais e Não-Formais. 1. ed. Lisboa: Editora da Universidade de Lisboa, 2014. v. 1, p. 51-66.

FRANCO, Maria Laura P. B. Análise de conteúdo. Brasília, 2. Ed.: Liber Livro Editora, 2005.

FREIRE, Paulo. Educação como prática da liberdade. Rio de Janeiro: Paz e Terra, 2011.

FREIRE, Paulo. Pedagogia da autonomia: saberes necessários à prática educativa. 6.ed. São Paulo: Paz e Terra, 1998.

FREIRE, Paulo. Pedagogia do Oprimido. 17 ed. Rio de Janeiro: Paz e Terra; 1997.

FREITAS, Luiz Carlos de. Crítica da organização do trabalho pedagógico e da didática. Campinas, SP: Papirus, 2012.

FREITAS. Maria Teresa. Letramento Digital e Formação de Professores. Educação em Revista: Belo Horizonte. v.26, n.03, p.335-352. dez. 2010.

FRIGOTTO, Gaudêncio. O enfoque da dialética materialista histórica na pesquisa educacional. In: FAZENDA, Ivani (org.). Metodologia da pesquisa educacional. São Paulo: Cortez, 2010.

FRIGOTTO, Gaudêncio; CIAVATTA, Maria. Trabalho como princípio educativo. In: Dicionário da Educação do Campo. Rio de Janeiro, São Paulo: Escola Politécnica de Saúde Joaquim Venâncio, Expressão Popular, 2012; pp. 748- 
759.

GDF. Secretaria de Estado de Educação. Subsecretaria de Educação Básica. Orientação Pedagógica: projeto político-pedagógico e coordenação pedagógica nas escolas. Brasília, 2014. Disponível em http://www.cre.se.df.gov.br/ascom/documentos/orientacao_pedagoggica_projet o_politico_pedagogico.pdf Acesso em dez/2014.

GONSALES, Priscila. Recursos Educacionais Abertos, formação de professores e o desafio de educar na cultura digital. In: Pesquisa sobre o uso das tecnologias de informação e comunicação nas escolas brasileiras: TIC Educação 2013. 1. ed. São Paulo : Comitê Gestor da Internet no Brasil, 2014. pp.53-59.

GONZÁLEZ REY, F.L. Pesquisa qualitativa em psicologia: caminhos e desafios. Tradução: Marcel Aristides Ferrada Silva. São Paulo: Pioneira Thomson Learning, 2005.

GRITTI, Silvana Maria. Educação rural e capitalismo. Passo Fundo: UPF, 2003.

Guia de livros didáticos: PNLD Campo 2013: Guia de Livros. - Brasília: Ministério da Educação, Secretaria de Educação Continuada, Alfabetização, Diversidade e Inclusão, 2012.

HALMANN, Adriane Lizbehd. Autoria de conteúdos digitais por professores em formação: potencialidades para apropriações científico-tecnológicas. Universidade Federal da Bahia. Faculdade de Educação, Salvador, 2011.

KENSKI, Vani Moreira. Educação e tecnologias: o novo ritmo da informação. Campinas, SP: Papirus, 2007.

KOLLING, Edgar Jorge; NÉRY, Irmão; MOLINA, Mônica Castagna (orgs.). Por uma educação básica no campo. Brasília: Universidade de Brasília, 1999.

LACERDA SANTOS, Gilberto. A Internet na escola fundamental: sondagem dos modos de uso por professores. Educação e Pesquisa (Revista da Faculdade de Educação da USP), v. 29, № 2, p. 303-313, 2003b.

LACERDA SANTOS, Gilberto. Ciência, tecnologia e formação de professores para o ensino fundamental. Brasília: Editora Universidade de Brasília, 2005.

LACERDA SANTOS, Gilberto. Formar professores para a educação mediada por tecnologias: elucidação da problemática por meio de seis investigações acadêmicas. Anais do XIII ENDIPE - Encontro Nacional de Didática e Prática de Ensino. Recife, PE: Universidade de Pernambuco, 2006a.

LEFEVRE, Fernando; LEFEVRE, Ana Maria. Depoimentos e discursos: uma proposta de análise em pesquisa social. Brasília: Liber Livros Editora, 2005.

LEITE, Sérgio Celani. Escola rural: urbanização e políticas educacionais. São Paulo: Cortez, 1999.

LÉVY, Pierre. A inteligência coletiva: por uma antropologia do ciberespaço. São Paulo: Edições Loyola, 1998

LÉVY, Pierre. Cibercultura. São Paulo: Editora 34, 1999. 
LÜDKE, Menga; ANDRÉ, Marli E. D. A. Pesquisa em educação: abordagens qualitativas. São Paulo: EPU, 1986.

MACHADO, Catarina dos Santos. Formação de educadores e a construção da escola do campo: um estudo sobre a prática educativa no Colégio Estadual Vale da Esperança - Formosa/GO. Dissertação de Mestrado. Faculdade de Educação. Universidade de Brasília. Brasília, 2014.

MAREN, Jean-Marie van Der. En quête d'une recherche pratique. Révue des Sciences Humaines, Paris, n. 142, out. 2003, entrevista concedida a Gaëtane Chapelle. [Tradução livre e comentada do Prof. Dr. Rogério de Andrade Córdova].

MARTÍ, José. Ideário pedagógico. La Habana: Centro de Estudios Matianos, 2011.

MASETTO, M.T. Mediação pedagógica e o uso da tecnologia. In: MORAN, J.M.; MASETTO, M.T.; BEHRENS, M.A. Novas tecnologias e mediação pedagógica. Campinas, SP: Papirus, 2004.

MATURANA, H. e VARELA, F. A árvore do conhecimento, Campinas, SP, ed. Psy II, MDA - Ministério do Desenvolvimento Agrário. Disponível em: http://www.mda.gov.br/portal/index/show/index/cod/134/codlnterno/19319.

Acesso em: 10/01/2010.

MATURANA, Humberto. Cognição, ciência e vida cotidiana. Belo Horizonte: Ed. UFMG, 2001.

MATURANA, Humberto. Emoções e linguagens na educação e na política. Belo Horizonte: UFMG, 1998.

MEDEIROS, Maria Osanette de. Novos olhares, novos significados: a formação de educadores do campo. Tese de Doutorado. Faculdade de Educação. Universidade de Brasília. Brasília, 2012.

MEIRIEU, Philippe. A pedagogia entre o dizer e o fazer: a coragem de recomeçar. Porto Alegre: Artmed, 2002.

MÉSZÁROS, Istvan. A educação para além do capital. São Paulo: Boitempo, 2008.

MÉSZÁROS, Istvan. A teoria da alienação em Marx. São Paulo: Boitempo, 2006.

MINAYO, M. C. S. (Org.). Pesquisa social - teoria, método e criatividade. 14ed. Petrópolis, Rio de Janeiro: Vozes, 1999.

MOCHCOVITCH, Luna Galano. Gramsci e a escola. São Paulo: Editora Ática, 2004.

MOLINA, Mônica Castagna. Análises de práticas contra-hegemônicas na formação de educadores: reflexões a partir do curso de licenciatura em Educação do Campo. In: CUNHA, Célio da; SOUSA, José Vieira de; SILVA, Maria Abádia da (orgs.). 0 método dialético na pesquisa em educação. Campinas, SP: Autores Associados/Brasília, DF: Faculdade de Educação, Universidade de Brasília, UnB, 2014. pp.263-290.

MOLINA, Mônica Castagna; SÁ, Laís Maria Borges Mourão (orgs.). Licenciaturas em Educação do Campo: registros e reflexões a partir das 
experiências piloto. Belo Horizonte: Autêntica Editora, 2011.

MOLINA, Mônica Castagna; SÁ, Laís Maria Borges Mourão. A Licenciatura em Educação do Campo na Universidade de Brasília: estratégias políticopedagógicas na formação de educadores do campo. In: MOLINA, Mônica Castagna; SÁ, Laís Maria Borges Mourão (orgs.). Licenciaturas em Educação do Campo: registros e reflexões a partir das experiências piloto. Belo Horizonte: Autêntica Editora, 2011.

MOLINA, Mônica Castagna; SÁ, Laís Maria Borges Mourão. Escola do Campo. In: CALDART, Roseli Salete; PEREIRA, Isabel Brasil; ALENTEJANO, Paulo; e FRIGOTTO, Gaudêncio (Orgs.). Dicionário da Educação do Campo. Rio de Janeiro, São Paulo: Escola Politécnica de Saúde Joaquim Venâncio, Expressão Popular, 2012; pp. 324-331.

MOLINA, Mônica Castagna; SÁ, Laís Maria Borges Mourão; FERREIRA, Márcio, CASTRO, Wanessa de. Licenciatura em Educação do Campo da Universidade de Brasília: os desafios da formação de educadores do campo para uso das tecnologias na educação. In: III Encontro Nacional de Pesquisa em Educação do Campo III Seminário sobre Educação Superior e as Políticas para o Desenvolvimento do Campo Brasileiro I Encontro Internacional de Educação do Campo, Brasília. Universidade de Brasília, 2010.

MORAES, Maria Cândida. Subsídios para fundamentação do Programa Nacional de Informática na Educação. Brasília: SEED/MEC, 1997.

MORAES, Raquel de Almeida; MONIZ, Lino Vaz. Amílcar Cabral e Paulo Freire na era da tecnologia digital. Revista da ABPN, v. 5, n. 10, mar.-jun., 2013.

MORAN, J.M.; MASETTO, M.T.; BEHRENS, M.A. Novas tecnologias e mediação pedagógica. Campinas, SP: Papirus, 2004.

MORAN, José Manuel. Ensino e aprendizagem inovadores com tecnologias audiovisuais e telemáticas. In: MORAN, José Manuel; MASETTO, Marcos T.; BEHRENS, Marilda Aparecida. Novas Tecnologias e mediação pedagógica. São Paulo : Papirus, 2004.

MORAN, José Manuel. Os novos espaços de atuação do professor com as tecnologias. Disponível em: <http://www.eca.usp.br/prof/moran/espacos.htm> Acesso em 24 mai. 2006.

MORIN, ANDRÉ. Pesquisa-ação integral e sistêmica: uma antropopedagogia renovada. Tradução: Michel Thiollent. Rio de Janeiro: DP\&A, 2004.

MOROZ, Melania; \& GIANFALDONI, Mônica Helena T. A. O processo de pesquisa: Iniciação. Brasília: Liber Livro Editora, 2.ed., 2006.

NASCIMENTO, Núria Renata Alves. Memórias da prática pedagógica: autobiografia de uma educadora em formação. 2013. Monografia de conclusão de curso - Licenciatura em Educação do Campo - Faculdade UnB Planaltina (FUP), Brasília.

NÉDER, Ricardo T. A produção de conhecimento na universidade e os estudos sociais da ciência e tecnologia: contribuições para o ensino e a pesquisa. In: 
NÉDER, Ricardo T. (org.). CTS Ciência Tecnologia Sociedade - e a produção de conhecimento na universidade. Brasília: Observatório do Movimento pela Tecnologia Social na América Latina. UnB/CAPES - Escola de Altos Estudos, Caderno Primeira Versão. Série 1. Construção Social da Tecnologia. Número 4. 2013.

OKADA, Alexandra (org.). Recursos educacionais abertos e redes sociais. São Luís: EDUEMA, 2013.

OKADA, Alexandra; MICROYANNIDIS, Alexander; MEISTER, Izabel; \& LITTLE, Suzanne. Coaprendizagem através de REA e redes sociais. OKADA, In: Alexandra (org.). Recursos educacionais abertos e redes sociais. São Luís: EDUEMA, 2013. pp. 164-175.

OLIVEIRA, Ramon de. Informática educativa: dos planos e discursos à sala de aula. Campinas, SP: Papirus, 2006.

PAIS, Luiz Carlos. Educação escolar e as tecnologias da informática. Belo Horizonte, MG: Autêntica, 2002.

PAPERT, Seymour. Logo: Computadores e Educação. São Paulo: Editora Brasiliense, 1998.

PEÑA, Maria de los Dolores J.; MEISTER, Izabel P.; AMBROGI, Ingrid Hötte; RANIERI, Paulo; NEPUNUCENO, Marcos; \& SANTOS, Bruno Carvalho dos. Recursos Educacionais Abertos: nova cultura de produção e socialização de saberes no ciberespaço. In: OKADA, Alexandra (org.). Recursos educacionais abertos e redes sociais. São Luís: EDUEMA, 2013.

PEREIRA, Maria de Lourdes Soares. As contribuições da Licenciatura em Educação do Campo na transformação das relações de gênero: um estudo de caso com as educandas do Assentamento Virgilândia de Formosa/GO. Dissertação de Mestrado. Faculdade de Educação. Universidade de Brasília. Brasília, 2014.

Pesquisa sobre o uso das tecnologias de informação e comunicação nas escolas brasileiras: TIC Educação 2013. 1. ed. São Paulo: Comitê Gestor da Internet no Brasil, 2014.

PIAGET, Jean. Abstração Reflexionante. (Becker, F. e Silva, P.B.G., Trad.) Porto Alegre: Artes Médicas, 1995.

PIAGET, Jean. O Nascimento da Inteligência na Criança. (Cabral, A., Trad.). Rio de Janeiro: Zahar, 1975.

PIAGET, Jean; GARCIA, R. Psicogêsene e História das Ciências. (Jesuíno, M.F.M.R., Trad.). Lisboa: Dom Quixote, 1987

RIBEIRO, Marlene. Movimento camponês, trabalho e educação; liberdade, autonomia, emancipação: princípios/fins da formação humana. São Paulo: Expressão Popular, 2010 (Capítulo 3, 165-198).

RIBEIRO, Marlene. Movimento camponês, trabalho e educação; liberdade, autonomia, emancipação: princípios/fins da formação humana. São Paulo: Expressão Popular, 2010. (Capítulo 3, 165-198).

ROCHA, Eliene Novaes. Das práticas educativas às Políticas Públicas: tramas e artimanhas pela Educação do Campo. Tese de Doutorado. 
Faculdade de Educação. Universidade de Brasília. Brasília, 2013.

SANTANA, Bianca; ROSSINI, Carolina; \& PRETTO, Nelson De Lucca. (Orgs.). Recursos Educacionais Abertos: práticas colaborativas políticas públicas. 1. ed. Salvador: Edufba, São Paulo: Casa da Cultura Digital. 2012. Disponível em http://www.rea.net.br/site/wp-content/uploads/2014/02/livrorea-g.jpg Acesso em out/2014.

SANTOS, Boaventura de Sousa (org.), Produzir para viver: os caminhos da produção não capitalista, Rio de Janeiro: Civilização Brasileira, 2005.

SANTOS, Boaventura de Sousa. A universidade no século XXI: para uma reforma democrática e emancipatória da universidade, São Paulo: Cortez, 2005.

SANTOS, Boaventura de Sousa. Um discurso sobre as ciências, São Paulo: Cortez, 2006.

SANTOS, Boaventura de Sousa; MENESES, Maria Paula G. de; NUNES, João Arriscado. Introdução: para ampliar o cânone da ciência: a diversidade epistemológica do mundo. In: SANTOS, Boaventura de Sousa (org.). Semear outras soluções: os caminhos da biodiversidade e dos conhecimentos rivais. Rio de Janeiro: Civilização Brasileira, 2005.

SANTOS, Elizana Monteiro dos. Prática pedagógica de estudantes da área de conhecimento de Ciências da Natureza e Matemática do Curso de Licenciatura em Educação do Campo da UnB. 2013. Monografia de conclusão de curso - Licenciatura em Educação do Campo - Faculdade UnB Planaltina (FUP), Brasília.

SANTOS, Milton. Por uma outra globalização - do pensamento único à consciência universal. São Paulo: Record, 2010.

SILVA, Edileuza F. da. A coordenação pedagógica como espaço de organização do trabalho escolar: o que temos e o que queremos. In: VEIGA, Ilma Passos Alencastro (Org.). Quem sabe faz a hora de construir o projeto político-pedagógico. Campinas: Papirus, 2007.

SILVA, Marco Antônio Baratto Ribeiro da. Educação do campo e agroecologia: continuidades e rupturas na história do Assentamento Vereda II - Padre Bernardo-GO. Dissertação de Mestrado. Faculdade de Educação. Universidade de Brasília. Brasília, 2014.

SILVA, Marco. Sala de aula interativa - a educação presencial e a distância em sintonia com a era digital e com a cidadania. INTERCOM - Sociedade de Estudos Interdisciplinares da Comunicação. XXIV Congresso Brasileiro da Comunicação. Campo Grande, MS, 2001.

SILVA, Marco. Sala de aula interativa. RJ: Quartet, $3^{\underline{a}}$ ed. 2002.

SILVA, Maria do Socorro. Educação do Campo e Desenvolvimento: uma relação construída ao longo da história. Disponível em http://www.contag.org.br/imagens/f299Educacao_do_Campo_e_Desenvolvime nto_Sustentavel.pdf Acesso em jan/2013.

SILVA, Vicente de Paulo Borges Virgolino da. A formação de valores cooperativos $e$ as transformações nas práticas educativas: um estudo de caso de educandos da Licenciatura em Educação do Campo da 
UnB, no assentamento Itaúna - GO. Tese de Doutorado. Faculdade de Educação. Universidade de Brasília. Brasília, 2012.

SOARES, Leôncio (org.) Convergências e tensões no campo da formação e do trabalho docente. Belo Horizonte: Autêntica, 2010.

SOARES, Magda. Novas práticas de leitura e escrita: letramento na cibercultura. In: Educação e Sociedade, Campinas, vol. 23, n. 81, p. 143-160, dez. 2002. Disponível em <http://www.cedes.unicamp.br> Acesso em dez/2014.

SOUZA, Maria Antônia de. Educação, escola e povos do campo: práticas educacionais em questão. In: SOARES, Leôncio [et. al.]. Convergências e tensões no campo da formação e do trabalho docente. Belo Horizonte, MG: Autêntica, 2010.

STAROBINAS, Lilian. REA na educação básica: a colaboração como estratégia de enriquecimento dos processos de ensino-aprendizagem. In: SANTANA, Bianca; ROSSINI, Carolina; \& PRETTO, Nelson De Lucca. (Orgs.). Recursos Educacionais Abertos: práticas colaborativas políticas públicas. 1. ed. Salvador: Edufba, São Paulo: Casa da Cultura Digital. 2012. Disponível em http://www.rea.net.br/site/wp-content/uploads/2014/02/livrorea-g.jpg Acesso em out/2014. pp.121-129.

STAROBINAS, Lilian; MANCEBO, E. ; LOCATELLI, S. O uso de ferramentas da Web no Ensino Médio da Escola Vera Cruz, 2008. Disponível em: http://pt.scribd.com/doc/6218217/O-Uso-de-Ferramentas-Da-Web-No-EnsinoMedio-Da-Escola-Vera-Cruz Acesso em jan/2013.

SZYMANSKI, Heloísa (org.); ALMEIDA, Laurinda Ramalho; PRANDINI, Regina Célia Almeida Rego. A entrevista na pesquisa em educação: a prática reflexiva. Brasília: Liber Livro Editora, 2004.

SZYMANSKI, Heloísa. Entrevista reflexiva: um olhar psicológico sobre a entrevista em pesquisa. In: SZYMANSKI, Heloísa (org.); ALMEIDA, Laurinda Ramalho; PRANDINI, Regina Célia Almeida Rego. A entrevista na pesquisa em educação: a prática reflexiva. Brasília: Liber Livro Editora, 2004.

SZYMANSKI, Heloísa; ALMEIDA, Laurinda Ramalho; PRANDINI, Regina Célia Almeida Rego. Perspectivas para a análise de entrevistas. In: SZYMANSKI, Heloísa (org.); ALMEIDA, Laurinda Ramalho; PRANDINI, Regina Célia Almeida Rego. A entrevista na pesquisa em educação: a prática reflexiva. Brasília: Liber Livro Editora, 2004.

TEIXEIRA, Edival Sebastião; BERNARTT, Maria de Lourdes; TRINDADE, Glademir Alves. Estudos sobre Pedagogia da Alternância no Brasil: revisão de literatura e perspectivas para a pesquisa. Educação e Pesquisa, São Paulo, v.34, n.2, p. 227-242, maio/ago. 2008.

THIOLLENT, Michel. Metodologia da Pesquisa-ação. 18.ed. São Paulo - SP: Cortez Editora, 2011.

TRINDADE, Domingos Rodrigues. O potencial da Licenciatura em Educação do Campo da Universidade de Brasília para a produção de ações contrahegemônicas: um estudo de caso no Assentamento Itaúna em PlanaltinaGO. Brasília, 2011. Dissertação de Mestrado. Faculdade de Educação. 
Universidade de Brasília.

TRIVIÑOS, Augusto Nibaldo Silva. Introdução à Pesquisa em Ciências Sociais: a pesquisa qualitativa em Educação. São Paulo: Editora Atlas, 2008.

UnB-FUP. Universidade de Brasília. Faculdade UnB Planaltina. A hipermídia como instrumento de melhoria na formação de professores da educação do campo. Brasília, Mimeo, 2009a.

UnB-FUP. Universidade de Brasília. Faculdade UnB Planaltina. Licenciatura em Educação do Campo - Projeto Político Pedagógico. Brasília, Mimeo, 2009b.

VALENTE, José Armando (Org.). O Computador na Sociedade do Conhecimento. Campinas: Gráfica do NIED, 1999.

VALENTE, José Armando. Pesquisa, comunicação e aprendizagem com o computador. O papel do computador no processo ensino-aprendizagem. In: ALMEIDA, M.E.B. de; MORAN, J.M. Integração das Tecnologias na Educação/ Secretaria de Educação a Distância. Brasília: Ministério da Educação, Seed, 2005.

VALENTE, José Armando. (org.). O computador na sociedade do conhecimento. Campinas, SP: UNICAMP/NIED, 1999.

VIDAL, E.M.; MAIA, J.E.B.; LACERDA SANTOS, G. Educação, informática e professores. Fortaleza, CE: Edições Demócrito Rocha, 2002.

VILLAS BÔAS, Rafael Litvin. Educação do Campo, questões estruturais brasileiras e formação de professores. In: MOLINA, Mônica Castagna; SÁ, Laís Maria Borges Mourão (orgs.). Licenciaturas em Educação do Campo: registros e reflexões a partir das experiências piloto. Belo Horizonte: Autêntica Editora, 2011. pp. 307-318.

VYGOTSKY, Lev. Pensamento e Linguagem. 3 $3^{a} e d$. São Paulo: Martins Fontes, 2005.

VYGOTSKY, Lev. S. A Formação Social da Mente. $5^{\mathrm{a}}$ ed. São Paulo: Martins Fontes, 1994.

WHITAKER, Dulce Consuelo A.; ANTUNIASSI, Maria Helena. Escola pública localizada na zona rural: contribuição para a sua reestruturação. São Paulo; Fundação para o Desenvolvimento da Educação, Centro de Estudos Rurais e Urbanos, 1992.

XAVIER, Antonio Carlos dos Santos. Letramento digital e ensino. Disponível em https://www.ufpe.br/nehte/artigos/Letramento\%20digital\%20e\%20ensino.pdf Acesso em nov/2014. S/D.

\section{SÍTIOS IMPORTANTES PARA ESTA PESQUISA:}

\section{$\checkmark$ http://www.rea.net.br/site/}


$\checkmark$ https:/upload.wikimedia.org/wikipedia/commons/transcoded/b/bd/Recurs os Educacionais Abertos \%28Alta Resolu\%C3\%A7\%C3\%A30\%29.og v/Recursos Educacionais Abertos \%28Alta Resolu\%C3\%A7\%C3\%A3 o\%29.ogv.720p.webm

$\checkmark$ https://commons.wikimedia.org/wiki/File:Recursos Educacionais Aberto s (Alta Resolu\%C3\%A7\%C3\%A30).ogv

$\checkmark$ http://oer.kmi.open.ac.uk/

$\checkmark$ http://www.unesco.org/new/fileadmin/MULTIMEDIA/HQ/CI/WPFD2009/P ortuguese Declaration.html

$\checkmark$ http://www.rea.net.br/educarede/

$\checkmark$ http://portaldoprofessor.mec.gov.br/index.html

$\checkmark$ http://objetoseducacionais2.mec.gov.br/

$\checkmark$ http://www2.virtual.ufc.br/portal2/index.php/projetos/banco-internacionalde-objetos-educacionais

$\checkmark$ http://mira.org.br/

$\checkmark$ http://www.educacaoaberta.org.br/

$\checkmark$ http://educacaoaberta.org/

$\checkmark$ http://creativecommons.org/licenses/ 
APÊNDICES 
APÊNDICE A - Questionário sobre Recursos de Tecnologia da Informação

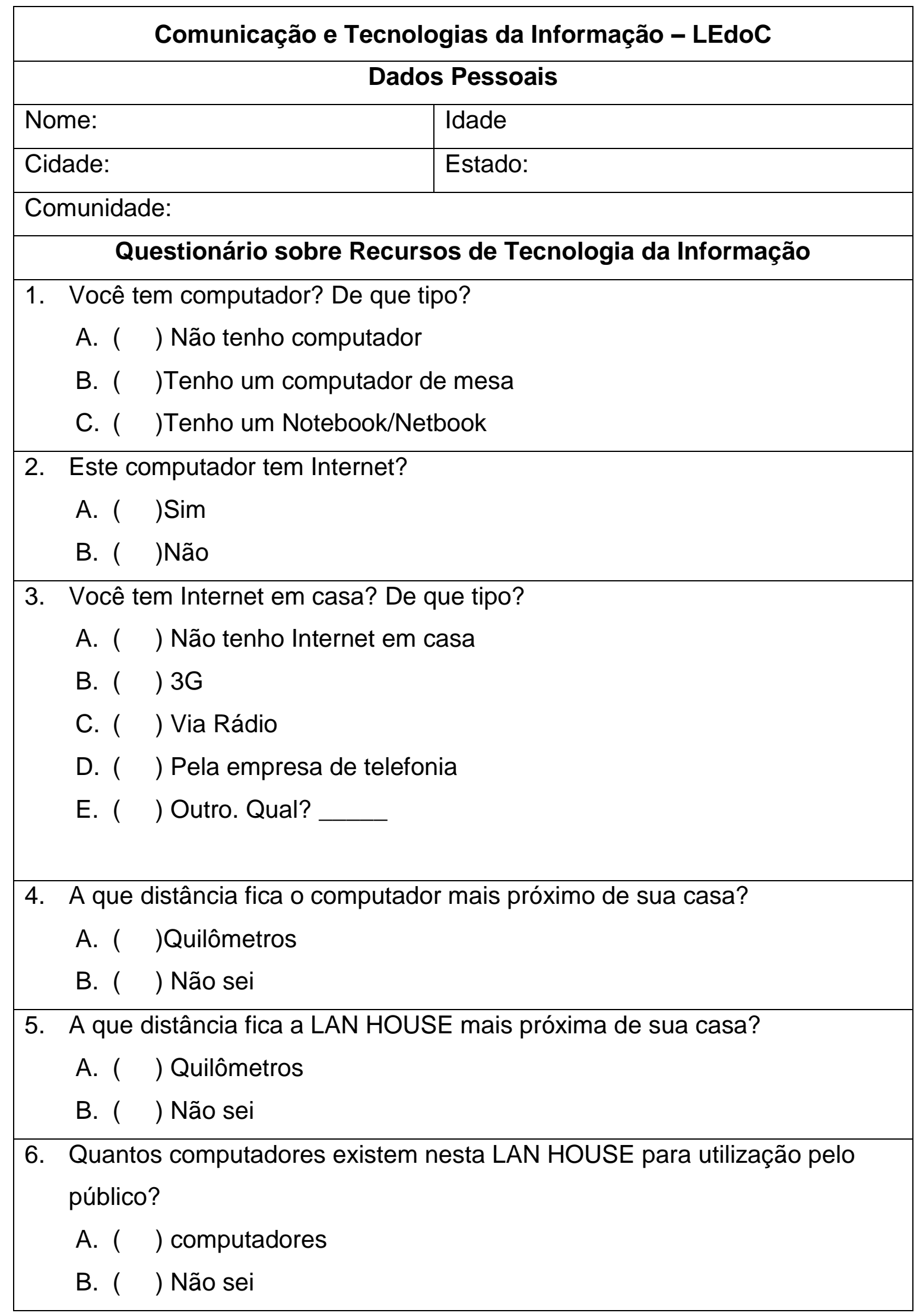


7. Como é a sua Internet?
A. ( ) Ruim
B. ( ) Regular
C. ( ) Boa

8. Você consegue ver vídeos em sua Internet?
A. ( ) Não.
B. ( ) Sim e demora bem pouco.
C. ( ) Sim, mas demora muito.

9. Você tem Orkut?
A. ( ) Sim
B. ( ) Não
C. ( ) Não sei o que é Orkut

10. Quantas vezes você acessa o Orkut por semana?
A. ( ) Vezes
B. ( ) Não acesso ou não sei o que é Orkut

11. Qual é o seu e-mail?
A. Meu e-mail é (
B. ( ) Não tenho e-mail

12. De quanto em quanto tempo você acessa (lê) seus e-mails?
A. ( ) Todos os dias
B. ( ) De 2 em 2 dias
C. ( ) De 3 em 3 dias
D. ( ) Uma vez por semana
E. ( ) Uma vez a cada 15 dias
F. ( ) Uma vez por mês
G. ( ) Não tenho e-mail

13. Qual é o banco mais próximo de sua comunidade?

14. A que distância fica o banco mais próximo de sua comunidade? ( ) Quilômetros

15. Que tipo de banco é? 


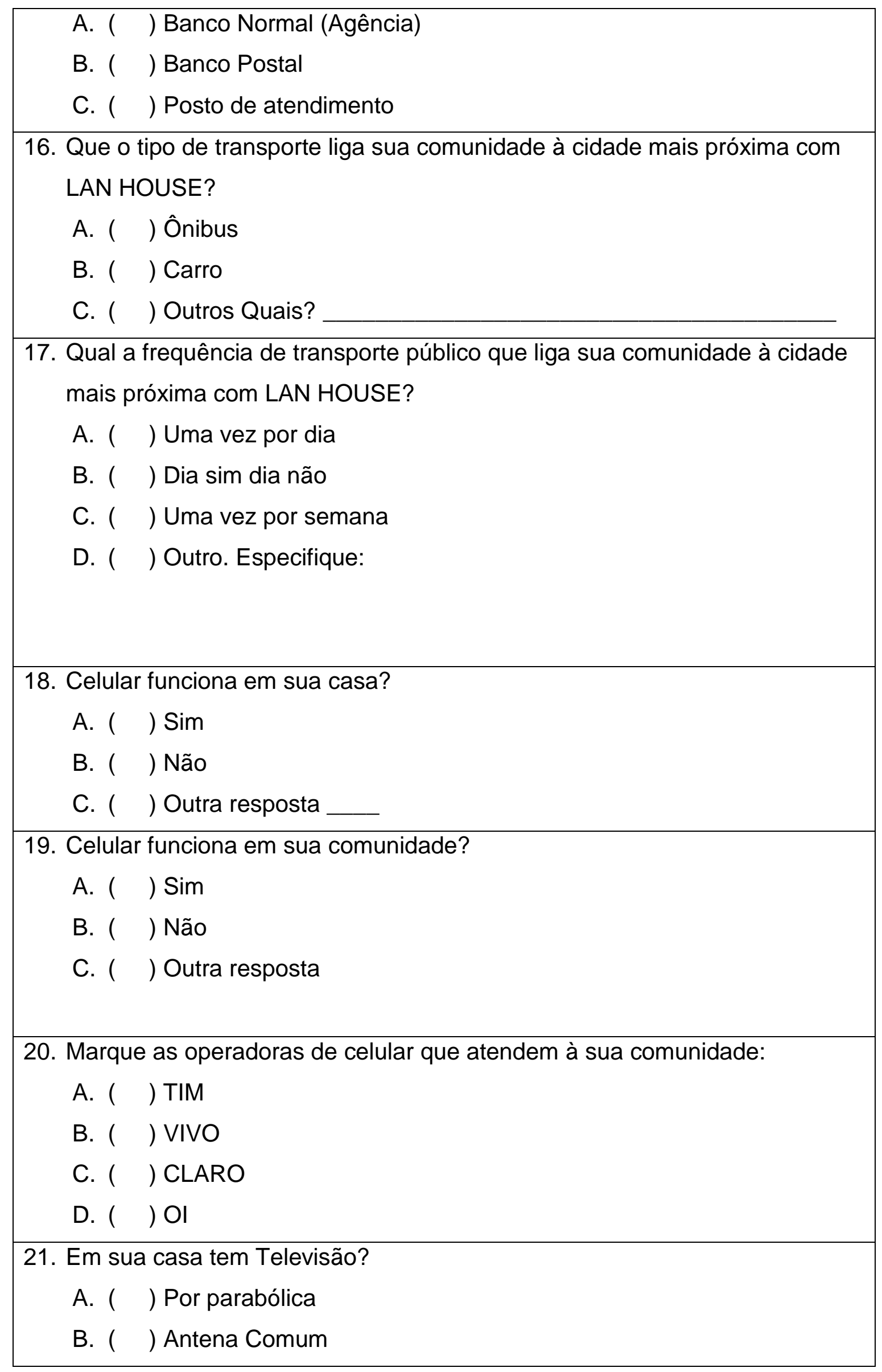




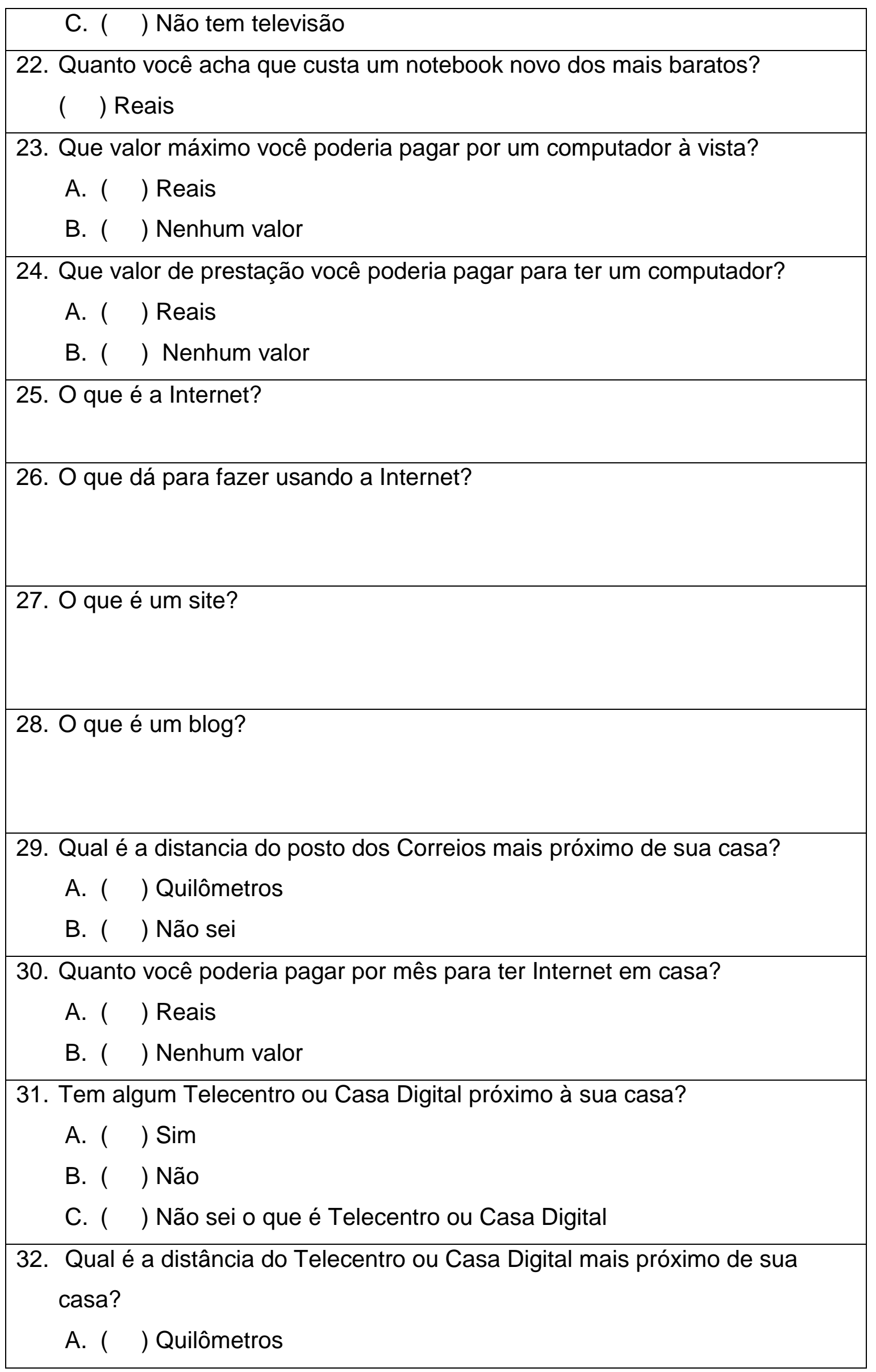




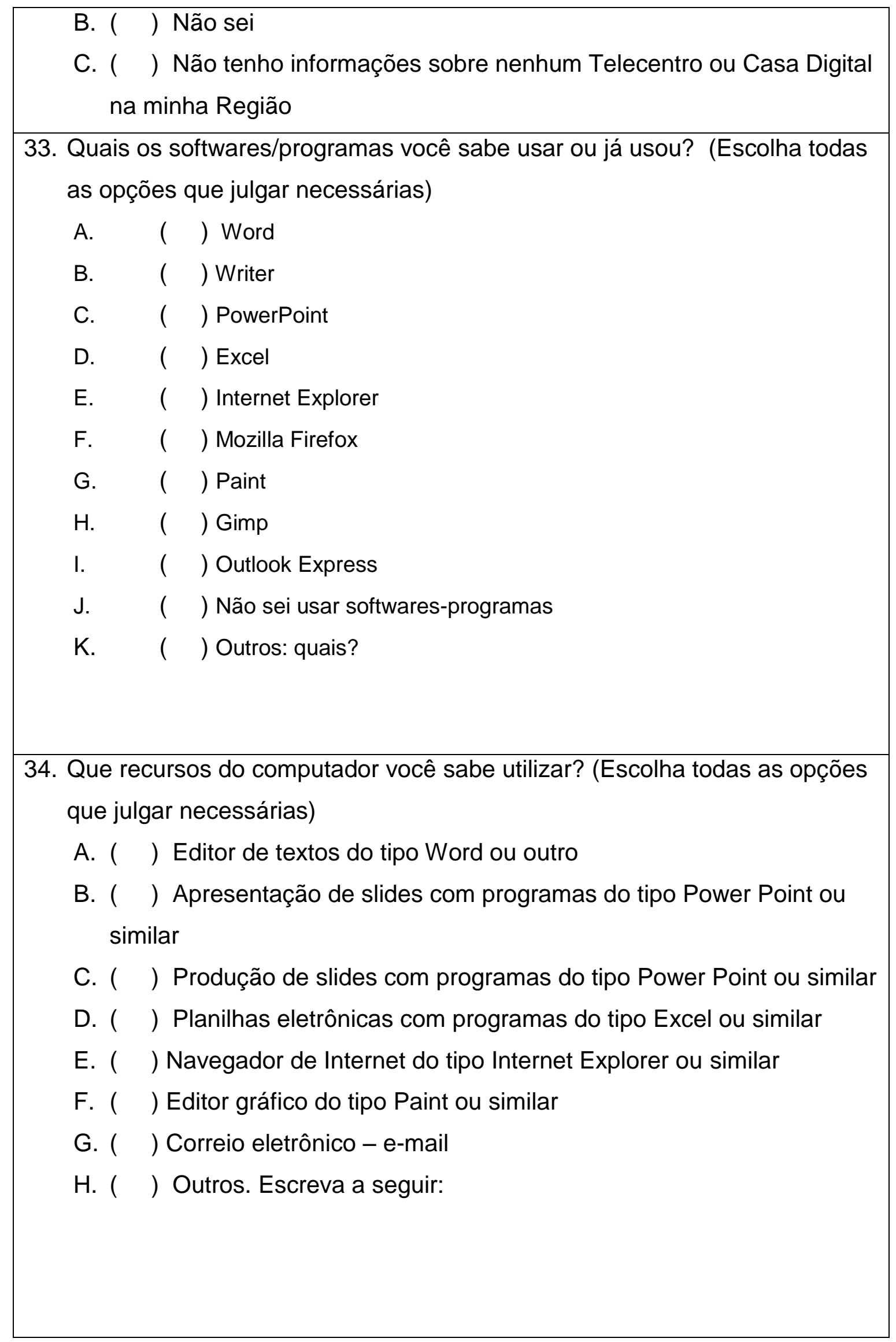


35. Quando você vai utilizar o computador: (Escolha única)
A. ( ) Às vezes precisa da ajuda de colegas
B. ( ) Sempre precisa da ajuda de colegas
C. ( ) Consegue utilizar o computador sozinho, sem dificuldade
D. ( ) Utiliza o computador com dificuldade, mas faz sozinho o que deseja
E. ( ) Outra resposta:

36. Com que regularidade você faz o uso do computador? (Escolha única)
A. ( ) Uma vez por semana
B. ( ) Duas vezes por semana
C. ( ) Várias vezes por semana. Quantas?
D. ( ) De vez em quando
E. ( ) Todos os dias
F. ( ) Não uso o computador

37. A partir do momento em que aprendeu a usar o computador, o que mudou em sua vida? (Escolha única)
A. ( ) Ainda não sei usar o computador
B. ( ) Meu trabalho ficou mais fácil
C. ( ) Meu trabalho ficou mais difícil
D. ( ) Não alterou em nada o meu trabalho
E. ( ) Houve mudanças, mas não sei dizer quais
F. ( ) Outros. Especifique a seguir:

38. A lista abaixo apresenta coisas que podem ser feitas com computador. Marque aquelas que você já ouviu falar:

\begin{tabular}{|l|l|}
\hline 1. ( ) & Simulações \\
\hline 2. ( ) & Jogos \\
\hline 3. ( ) & Edição de texto (Word, Bloco de notas, etc) \\
\hline 4.( ) & Desenho digital (Paint e similares) \\
\hline 5. ( ) & Apresentações/Construção de slides (PowerPoint e similares) \\
\hline 6. ( ) & Criação e/ou manutenção de blogs \\
\hline 7.( ) & Desenvolvimento de projetos escolares usando computador e Internet \\
\hline
\end{tabular}




\begin{tabular}{|l|l|}
\hline 8. ( ) & Busca e seleção de informações na Internet (pesquisa) \\
\hline 9. ( ) & Nenhuma \\
\hline $\begin{array}{l}\text { 39. O computador contribui para aumentar/melhorar o conhecimento? Como? } \\
\text { Por quê? Justifique sua resposta: }\end{array}$ \\
$\begin{array}{l}\text { 40. O computador melhora ou piora a comunicação entre as pessoas? Por } \\
\text { quê? }\end{array}$ \\
\end{tabular}




\section{APÊNDICE B - Relatos das aulas de CTI}

As sínteses a seguir buscam mostrar as opiniões dos sujeitos individuais (Turma 2), postas em discussão no coletivo, organizadas, adequadas e formalizadas pelos docentes. É importante dizer que jamais foi possível dissociar, distinguir, separar totalmente, os elementos da relação educativa, sejam eles o conteúdo, os contextos ou os sujeitos (educandos ou educadores).

O esforço por essa organização foi no sentido de tornar a complexidade dos registros de nossos diálogos algo compreensível a outros leitores que não tenham convivido neste processo. Logo, as sínteses por nós organizadas não correspondem ao texto literal dos educandos, mas são produtos da interlocução, do diálogo, da coparticipação entre educadores e educandos na construção de um processo que foi ensino, aprendizagem, avaliação, memória e registro simultaneamente.

Em decorrência disso, temos, em vários momentos, o entretecimento das falas dos vários sujeitos aí envolvidos, educandos ou educadores. Vale lembrar que a presença dos educadores, no momento específico das sínteses das aprendizagens, é marcada pela predominância do trabalho de capturar as opiniões, estimular o debate, deixar emergir os conflitos, coordenar as falas, redigir as informações coletadas (sempre perguntando se as informações condiziam com o que os educandos estavam expressando) e fazer o registrosíntese dos discursos (FERREIRA, 2014, p.55).

Cabe, ainda, lembrar que o esquema aqui exposto não é rígido e nem fechado, a cada TE são realizadas as necessárias adaptações e replanejadas as atividades, de acordo com necessidades do coletivo e também da Coordenação do Curso/Turma, bem como com as impressões trazidas pelos educandos de suas comunidades a cada TC. Então, assim são organizadas as atividades de CTI. 


\section{Aula 1}

\section{Conteúdo}

> Computador e sociedade contemporânea; Exclusões do campo brasileiro.

\section{Objetivos}

> Discutir para quê serve o computador na sociedade contemporânea e para os sujeitos do campo; analisar se os sujeitos do campo passam por processos de exclusão digital a partir dos próprios relatos dos educandos.

> Investigar como o avanço tecnológico da comunicação no meio rural se relaciona/impacta com/os processos de desenvolvimento (educativo, social, cultural, econômico, político) no campo.

\section{Conceitos permeadores}

Trabalho;

Homem como ser de necessidades.

\section{Síntese dos aprendizados}

$>$ O computador tem várias utilidades na sociedade contemporânea e mesmo tendo sido feito para servir aos interesses da classe dominante, se constitui uma ferramenta tecnológica importante que pode ser considerada como patrimônio intelectual da sociedade de um modo geral.

> O computador é um importante aliado tecnológico do homem no sentido do suprimento de suas necessidades. Computadores e Internet são ferramentas que facilitam a comunicação humana e favorecem o acesso à informação.

$>$ O computador é um recurso criado inicialmente para servir às 
necessidades militares dos Estados Unidos e que foi apropriado pelas universidades no sentido de se tornar mecanismo de produção e divulgação de informações e de conhecimento.

> O computador praticamente inexiste no campo. Internet, então, praticamente não há. Mas o campo e seus sujeitos também têm direito ao acesso à informação, pois não ter acesso a isso vai afastar cada vez mais sujeito do campo do conhecimento.

Não há dúvida de que o homem do campo sofre uma exclusão de oferta de computadores e Internet no campo. Esta exclusão só vem se associar às outras tantas como falta de acesso a uma Educação do Campo, falta de políticas de fortalecimento da agricultura familiar, abandono do Estado, e invasão do agronegócio ao campo brasileiro. Vale lembrar que os donos dos recursos do agronegócio tem computadores e Internet disponíveis, inclusive, tratores guiados remotamente por satélite.

O avanço tecnológico no meio rural praticamente inexiste para o trabalhador da agricultura familiar, mas abunda nas grandes propriedades onde $\mathrm{o}$ dono da fazenda tem máquinas de última geração, computadores, Internet, ordenhadoras poderosas, sistemas de rastreamento de rebanhos, etc. Ocorre a absoluta falta de equipamentos de informática nas Escolas do Campo e não é só isso: faltam coisas básicas como papel, mimeógrafos, cadeiras, mesas, transporte para educandos e professores, salas de aula e espaço nas salas de aula.

> Quando se vai pensar sobre a falta de computadores e Internet na escola e no campo, acabamos pensando em outras tantas carências e exclusões essenciais ligadas à necessidade de produzir para sobreviver, de ter saúde, de termos respeitada a cultura local.

\section{Aula 2}

\section{Conteúdo}


Aprender a ligar, desligar, clicar e selecionar no ambiente Windows.

> Software e Hardware: noções; primeiros contatos: ligar, desligar, clicar selecionar.

\section{Objetivos}

$>$ Entender as questões técnicas essenciais do funcionamento de um computador.

\section{Conceitos permeadores}

$>$ Dialética.

\section{Síntese dos aprendizados}

> Aprender novas técnicas para fazer as coisas necessárias ao desenvolvimento da vida é importante e a construção do conhecimento técnico é necessária como forma de reduzir a força da opressão, da dominação, a separação entre ricos e pobres.

> Entender os meandros técnicos da tecnologia da informação é também entender o quê a elite do país e do mundo sabe, o que ela domina, o que ela produz e que muitas vezes nos serve. Lembre-se, outra vez que os recursos e as tecnologias criadas podem ser apropriadas para outras lutas contra a opressão.

> Aprender a usar computador nos coloca em um novo local para pensar o mundo. Surgem questões como: por que a informática existia o tempo todo e nós não sabíamos? Por que o mundo está mudando tanto e nós não estamos no barco dessas mudanças?

> É possível mudar a nossa realidade a partir disso... pelo menos um pouquinho, hoje, nossa realidade se modificou, pois aprendemos que há outras formas de escrever, de ler, de lidar com dados e informações.

$>$ Ter técnica é importante. Não ter acesso à técnica é mais uma faceta da negação de nossos direitos. Enquanto nós estamos velhos 
aprendendo essas coisas tão básicas da informática, as crianças da cidade já sabem de tudo isso... muito mais que nós.

> O mundo está mudando com essas tecnologias e o mundo não para de mudar e nós vamos ficando atrasados porque no campo essa formação não chega.

Estamos animados em saber que a partir de agora o trabalho da monografia e os trabalhos a serem feitos para as áreas de conhecimento vão se tornar mais fáceis.

Agora esse negócio de usar só Windows não é bom. Tem software livre, tem Linux e a gente fica usando esse Sistema da classe dominante.

\section{Aula 3}

\section{Conteúdo}

> Testes de digitação (apresentação do processador de texto); digitar, negritar, salvar, salvar como, tamanhos e tipos de fontes.

\section{Objetivos}

$>$ Introduzir os educandos à digitação em computador; realização de trabalho acadêmico utilizando processador de texto.

\section{Conceitos permeadores}

> Características da dialética.

\section{Síntese dos aprendizados}

> Vimos nessa aula que temos imensas dificuldades em fazer coisas que para a maioria das pessoas da cidade são bastante simples, como escrever algumas frases no processador de texto. Daí, vamos percebendo o quão distante desse universo das possibilidades da informática estávamos o tempo todo. O que a princípio era doloroso e lento vai se tornando, pela prática, produtivo e nos ajuda a resolver 
coisas importantes na LEdoC-UnB e nas nossas comunidades.

> Mesmo sendo uma atividade repetitiva esta de digitar, negritar, salvar, salvar como, alternar tamanhos e tipos de fontes, vemo-las como úteis para que possamos, além de fazer nossos trabalhos acadêmicos na LEdoC-UnB, melhorar nossa comunicação pelas normas padrões de escrita.

> O corretor ortográfico do Word, por exemplo, nos ajudou muito a melhorar nossa escrita. Ele avisa quando alguma coisa que escrevemos está errada.

> De tanto insistirmos por aprender a digitar, por adentrarmos à Universidade, temos feito progressos interessantes. Agora já sabemos fazer as coisas mais básicas do computador e estamos estudando, fazendo graduação, numa Universidade Federal... isso é importante e diz que nossa vida está em constante mudança tanto de quantidade quanto de qualidade.

> Quanto mais fazemos avanços aqui em CTI, mais aprendemos a lidar com o computador e mais acumulamos conhecimentos que vão nos tornando capazes de entender o mundo melhor, com olhares mais críticos e atentos.

> Assim, a gente vai crescendo intelectualmente e aprendendo novas formas de aprender... fazendo jus ao direito de estar aqui na UnB e na LEdoC-UnB.

> No tempo comunidade que veio depois que aprendemos a usar o Word (processador de texto) já deu para fazer algumas coisinhas com o computador, como, por exemplo, a digitação do texto para a apresentação do relatório do Tempo Comunidade. Sem ter aprendido isso, tudo teria que ser feito à mão.

> Mas deu muito trabalho, principalmente por não termos computador em casa... sem computador fica mais difícil treinar e ficar rápido na digitação.

Muitos pegaram emprestado computadores das associações de 
produtores, dos sindicatos, dos escritórios dos movimentos sociais.

\section{Aula 4}

\section{Conteúdo}

Usos comuns da Web: comunicar, comprar, aprender, ensinar, brincar;

Acesso à Internet: Conhecer elementos do navegador e símbolos (ícones) de navegação; Sites de pesquisa; Conta de e-mail.

\section{Objetivos}

> Conhecer e acessar a Internet; experimentar sites de pesquisa;

$>$ Entender como arquivos digitais são guardados;

> Discutir a importância da Internet como meio de acesso à informação.

\section{Conceitos permeadores}

Dialética: A luta dos contrários

\section{Síntese dos aprendizados}

> Havia muito preconceito em relação a Internet porque ela é vista no campo como desagregadora, como fonte de coisas ruins, de pornografia, de propaganda... como coisa que separa os pais e os filhos, onde os filhos ficam o tempo todo no computador e não dão mais atenção para as brincadeiras de correr, pegar, com as coisas da natureza.

> Esta visão foi sendo desmantelada à medida em que se discutiu o caráter das tecnologias cuja função, qualidades e defeitos é construído em razão das intenções de seu utilizador.

$>$ De fato, a Internet tem pornografia, jogos inúteis, redes sociais sem caráter produtivo e está assentada sobre um mercado muito forte que quer fazer propaganda e difundir o consumo pelo consumo.

Com o uso constante da Internet as pessoas passam a escrever errado 
pela supressão (tão comuns na comunicação pela Internet) de palavras e letras. Além disso, o uso da Rede gera o isolamento social onde as pessoas passam mais tempo consigo mesmas em casa e evitam se relacionar com as pessoas fora do mundo virtual. $\mathrm{O}$ uso da Internet também é considerado como uma atividade viciante que reduz a liberdade e altera o comportamento social dos sujeitos.

Acrescenta-se, ainda, que a Internet causa males à saúde como danos na coluna, lesão por esforço repetitivo, vista cansada, etc.

> Por outro lado, em contraposição aos problemas oriundos do uso da Internet aparecem suas qualidades positivas. A primeira delas é que é uma fonte inesgotável de disponibilização e fluxo de informações de todos os tipos, de todas as fontes, de todos os lugares, em todas as línguas.

A Internet tem grande potencial educativo por ser um espaço onde podem ser trocadas informações diversas, acessar artigos, teses, dissertações, trocar ideias.

Há muitas coisas que são possibilitadas pela disponibilidade da Internet como novas formas de buscar informação; maior agilidade e velocidade nos fluxos da informação; ampliação das relações profissionais e pessoais; rico instrumento de auxílio acadêmico; é um centro de entretenimento pela convergência das mídias; pode-se escolher o que se quer acessar; é um meio de comércio, de trocas de precificação; contribui para superação de distâncias entre as pessoas entre si e entre as pessoas e a informação.

> Por outro lado, a Internet sedimenta segregações onde aquele que não tem acesso fica prejudicado no perverso mundo da concorrência entre indivíduos. Logo, não ter acesso fomenta a diferença de oportunidades aumentando o fosso entre as classes.

Dentre os aspectos negativos do uso de Internet há outros a elencar: nem toda informação procede de fonte segura; dificuldade de selecionar informação pertinente porque há muito lixo; as relações profissionais acabam sendo contaminadas pelo imediatismo próprio do 
meio; relações pessoais não são aprofundadas pela frieza e necessidade de pressa típica desse modo de comunicação; nem sempre há como se certificar da correção das informações; invasão de privacidade pelo uso indevido de informações pessoais; espaço que também serve a crime e abusos; presença de pornografia infantil e adulta com acesso irrestrito; constante criação e disseminação de vírus digitais e spams; precarização da cultura escrita; jogos, e entretenimentos violentos e de cunho discriminatório ocupam as cabeças de crianças e adolescentes atrapalhando seus estudos, etc.

\section{Aula 5}

\section{Conteúdo}

> Autodiagnóstico de inclusão digital;

$>$ Conceito de tecnologia.

\section{Objetivos}

$>$ Conceituar Tecnologia.

> Refletir sobre a tabulação da entrevista sobre a disponibilidade de recursos de Tecnologias de Informação aos estudantes.

\section{Conceitos permeadores}

> Dialética: A luta dos contrários;

> Trabalho como conteúdo concreto da luta dos contrários.

\section{Síntese dos aprendizados}

A tecnologia não está contida apenas nos dispositivos eletrônicos modernos como computadores e celulares. Tratores, enxadas, animais de trabalho constituem tecnologias a serviço do homem. Umas tecnologias podem durar muito tempo e outras durarem muito pouco como, por exemplo, alguns celulares, computadores e carros.

> Novas tecnologias são lançadas o tempo todo... às vezes, uma determinada coisa ainda é útil como um celular ou computador e 
já lançam uma nova. Daí todo mundo é bombardeado com propaganda das grandes qualidades desse novo produto e acaba comprando. Isso gera um círculo vicioso e também muito lixo eletrônico. Sem contar que os recursos da natureza não são infinitos e boa parte dos objetos tecnológicos que ficam obsoletos rapidamente ainda não são recicláveis ou não tem uma outra tecnologia que os recicle. Tecnologia gera tecnologia. Tecnologia transforma tecnologia em lixo, também.

> Em meio a outras definições de tecnologia, construímos uma onde afirmamos que tecnologias são os conhecimentos e/ou artefatos que nos permitem produzir outros conhecimentos ou objetos de modo a ampliar nossas possibilidades de modificar a natureza e as relações com vistas à satisfação de nossas necessidades humanas.

> Dentre os principais objetivos da tecnologia consta o aumento da produtividade do trabalho humano gerando mais valia. Quanto mais avançada a tecnologia, maior será a diferença entre o custo de produção de uma coisa e a margem de venda deste produto. Isto é, maior será a diferença entre o que o patrão paga ao seu empregado e o lucro que este patrão terá.

A Informática é uma tecnologia também e pode ser entendida como o conjunto do que diz respeito ao trato com a informação de um modo geral passando pelos estudos sobre computação e construção de computadores e sobre as formas de processamento de dados e informações.

> Os males da tecnologia são diversos e passam pela precarização do trabalho humano; desemprego; geração de lixo tóxico; subvalorização da força de trabalho do homem; fortalecimento das forças de dominação; está nas mãos de poucos a capacidade de produzir tecnologias mais avançadas; o trabalhador não tem acesso às tecnologias mais avançadas ficando somente com as tecnologias que já tiveram seu poder de ação bastante desgastado e já estão sendo substituídas por tecnologias mais eficientes; o homem 
do campo que trabalha com agricultura familiar só fica com as tecnologias que já estão ultrapassadas e não tem acesso a produtos de ponta; algumas tecnologias degradam muito o meio ambiente como os defensivos agrícolas e sementes transgênicas.

Por outro lado, há bens e recursos tecnológicos que ajudam as pessoas a terem uma saúde melhor como aparelhos de diagnóstico por imagem, robôs que fazem cirurgias guiadas e sistemas que fazem cirurgias menos invasivas que as antigas; tratores guiados por satélites que são muito precisos; equipamentos de plantio e colheita com ar condicionado e guiados com auxilio de computadores e sensores; nas escolas da cidade tem lousas eletrônicas onde os educadores podem mover as coisas e ensinar melhor; aparelhos para educar com imagens e sons como projetores; escolas com laboratórios de informática para serem utilizados pelos educandos; escolas em que cada educando tem um tablet e lê seus livros nestes equipamentos; ainda tem a Educação a Distância com o uso de Ambientes Virtuais de Aprendizagem que fazem os conteúdos e a palavra do educador poderem chegar a qualquer lugar que tenha Internet e um computador e muitas outras coisas.

De um modo geral, todas essas boas tecnologias servem a uma minoria que são pequenos burgueses (classe média alta) ou os patrões e donos de empresas (classe efetivamente dominante). No campo tais tecnologias nunca chegaram... parece que o campo não tem pessoas precisando de saúde, de meios de se educar facilmente.

\section{Aula 6}

\section{Conteúdo}

> Exclusão digital e Exclusão social: reflexões sobre a brecha digital; endereço eletrônico; 


\section{Objetivos}

> Compreender a relação exclusão digital-exclusão social; criar e-mail; aprender a fazer apresentações de slide no computador e salvar em JPEG.

\section{Conceitos permeadores}

> Conceito de homem como ser de necessidades;

> A história humana como a história das relações entre homens e natureza e dos homens entre si

\section{Síntese dos aprendizados}

> Conceito de homem como ser de necessidades; A história humana como a história das relações entre homens e natureza e dos homens entre si.

> O homem precisa de meios para sobreviver no campo e a exclusão digital é mais uma exclusão por que passam os camponeses. Sem computadores e Internet e sem saber usar estes recursos, a compreensão de mundo pode ficar mais difícil ainda, pois estes são equipamentos de acesso à informação e recursos importantes para lidar com uma série de coisas no campo...

> Sem o mesmo acesso à informação que as demais pessoas têm na cidade as coisas vão ficando mais difíceis para que o agricultor permaneça produzindo com eficiência. Não ter e nem saber lidar com computador e Internet evita que o camponês aprenda mais, crie novas formas de produzir, conheça outras culturas, acesse políticas públicas e serviços públicos diversos oferecidos por meio da Internet. Um exemplo disso é o próprio vestibular da LEdoC-UnB cuja inscrição é feita apenas pelo site do CESPE.

> Muitas pessoas não fazem a inscrição porque não tem Internet perto de casa ou se têm não sabem como entrar e fazer a inscrição... muitos colegas perderam a oportunidade do vestibular para isso. O sujeito do campo precisa saber das coisas, precisa estudar, necessita produzir 
melhor, estar a par dos acontecimentos políticos do país porque, assim como todo o resto da população, também tem necessidades.

> Computador e Internet são novas tecnologias que vieram nos mostrar mais claramente o tamanho da diferença de acesso a informação que há entre quem tem dinheiro e quem não tem, quem tem os recursos, os meios e quem não os tem. Basta comparar as casas das pessoas da cidade com as casas dos sujeitos do campo: no campo praticamente nenhuma residência tem computador... Internet, então, quase impossível e enquanto isso boa parte das residências urbanas tem esses recursos disponíveis.

> Acesso à informação também é uma necessidade do homem que faz com que ele seja parte, de verdade, do mundo, de suas mudanças, de seus destinos. Com essa exclusão digital, cada vez mais algumas pessoas vão trabalhar com a cabeça e outros com os braços e isso é uma relação injusta... todos deveriam ter oportunidades iguais de aprenderem a usar os recursos que a humanidade criou e poder escolher o quê e como fazer sua vida.

\section{Aula 7}

\section{Conteúdo}

> Blog como ferramenta educativa: Marcando espaço no ciberespaço.

\section{Objetivos}

> Criar blog sobre sua própria atuação na LEdoC;

$>$ Como produzir conteúdo para Blogs.

\section{Conceitos permeadores}

$>$ Relação entre forças de produção, relações de produção e modos de produção.

\section{Síntese dos aprendizados}

A criação dos Blogs foi um momento interessante pelo fato de 
podermos registrar, ao longo de nossa estada na LEdoC-UnB os momentos de aula, as reflexões, os textos, enfim, é um modo de marcarmos nosso território na Internet. A ideia é alimentar o blog como um diário pessoal colocando as coisas que formos vivendo na Licenciatura... isso pode ser importante no momento de fazer a monografia, pois tudo estará registrado lá.

> Ter as coisas anotadas em um Blog e ir atualizando é bom porque essas informações vão continuar lá e podemos ver quando quisermos. De alguma maneira o Blog será uma forma de nos ajudar a produzir os conhecimentos na LEdoC-UnB, e aprender a lidar com isso pode abrir novas possibilidades para o futuro, para ensinarmos nossos educandos a usarem esta ferramenta para outras finalidades como geração de renda, por exemplo.

Há Blogs que vendem produtos, que trocam coisas, que oferecem consultoria em vários ramos, que ensinam, que guardam histórias. As possibilidades são muitas...

> Além disso, um Blog é um espaço de comunicação entre comunidades rurais, por exemplo, e pode ser útil para trocas de experiências com a agricultura e a pecuária ou até mesmo como modo de pensar e discutir as lutas sociais.

Podemos considerar o Blog como um instrumento de produção e divulgação de bens intelectuais, de bens culturais... todavia o acesso a Internet nas comunidades é um problema central que nos exclui, mais uma vez, de uma oportunidade potencialmente rica.

\section{Aula 8}

\section{Conteúdo}

> Moodle como espaço de interação educativa;

> Blogs como espaço de inserção de ideias e ideologias no ciberespaço;

$>$ Redes sociais como ferramentas de criação de coletivos; biblioteca 
virtual como alternativa de acesso a material acadêmico;

$>$ Portal do Professor.

\section{Objetivos}

> Conhecer utilidades educativas de plataformas como Moodle, Blogs, Redes sociais mais populares, Biblioteca Virtual da Educação do Campo, Portal do Professor (MEC).

\section{Conceitos permeadores}

> Relação entre forças de produção, relações de produção e modos de produção.

\section{Síntese dos aprendizados}

> Conhecer as possibilidades de interação educativa do Moodle se constituiu em grande surpresa já que neste AVA é possível reproduzir boa parte da disponibilidade de recursos didáticos e ainda permite fazer diálogos acerca do que está sendo ensinado e aprendido no momento.

> Em destaque o fato de que o uso de Moodle deixa os conteúdos das áreas de estudo sempre visíveis e é possível conversar sobre isso com o professor através de fóruns, chats e mensagens privadas.

> Ter vídeo, apresentação de slides, textos e outros recursos disponíveis no mesmo espaço em que se pode conversar sobre os conteúdos é bastante interessante e faz com que se possa consultar sempre os materiais propostos pelo professor no mesmo momento em que se pode perguntar e ser respondido.

> De fato, o Blog é uma ferramenta virtual de expressão que pode servir para produzir e divulgar ideias e ideologias. Esse instrumento de expressão pode servir (e tem servido prioritariamente) à classe dominante, mas também é possível que a classe trabalhadora possa usá-lo para o trabalho e a educação.

A discussão das redes sociais como ferramentas de criação de 
coletivos humanos foi iniciada com estranheza, mas com o decorrer das aulas fomos entendendo que é possível que nos encontremos e expressemos nossas opiniões pelo Facebook, por exemplo, seguindo ou sendo seguidos pelos companheiros que estão do mesmo lado que nós. Vale lembrar que alguns educandos têm perfis do Facebook onde postam exclusivamente denúncias e ações dos movimentos sociais em suas comunidades.

> Por outro lado, as redes sociais já estão bastante contaminadas pelos princípios do capitalismo no sentido de que tudo é para venda, tudo é para obtenção de lucro, que o mundo e as pessoas existem para comprar. Ainda são raros os perfis de pessoas que pensem de um modo diferente, discutindo as injustiças $e$ as desigualdades sociais.

> É importante destacar o nível de exclusão sentido pelos educandos que sequer sabiam da existência do Portal do Professor, uma instituição do Governo Federal feita no sentido de disponibilizar recursos digitais como e-books, sugestões de estratégias didáticas inovadoras, etc... outrossim, havia que se perguntar: será que estes materiais servem à Educação do Campo em suas peculiaridades ou são mais um conjunto de instrumentos ideológicos para fortalecer o afastamento do homem do trabalho, da natureza e de sua necessidade de ser um ser de relações?

Do mesmo modo, aconteceu com o contato com algumas bibliotecas virtuais como a Biblioteca Virtual de Literatura (http://www.biblio.com.br/), $\quad$ o Portal Domínio Público (http://www.dominiopublico.gov.br), Portal de Bibliotecas Digitais da Universidade de Brasília (http://portal.bce.unb.br/).

\section{Aulas 9 e 10}

\section{Conteúdo}

Blogs, web sites, redes de relacionamento, e-governo; 
Importância da Internet aberta;

Relevância da ocupação dos espaços nas novas mídias digitais.

\section{Objetivos}

> Refletir sobre os novos espaços de produção e divulgação da informação e do conhecimento já surgidos no bojo do avanço das Tecnologias Digitais;

> Pensar a inteligência coletiva, onde as produções intelectuais não são propriedade de uma pessoa, mas pertencem aos coletivos que a elas têm acesso ou que delas compartilham.

\section{Conceitos permeadores}

Base e superestrutura.

\section{Síntese dos aprendizados}

Com as Tecnologias de Informação e Comunicação surgem, também, outras possibilidades para a produção e divulgação de informações e do conhecimento. No trabalho educativo, quando temos acesso à Internet, a importância disso fica bastante clara, pois conseguimos ver e ler, por exemplo, as teses e dissertações voltadas aos conteúdos da Educação do Campo.

> Lembramos que alguns docentes sempre nos solicitam a pesquisa na Internet sobre suas áreas de conhecimento: é o caso de Economia Política.

> Quando digitamos no Google uma pergunta sobre o princípio do excedente, o princípio da substituição, o princípio da demanda efetiva, recebemos uma lista enorme de artigos, teses, páginas de Internet, Blogs sobre o assunto. Difícil mesmo é saber qual das informações está correta ou serve para os trabalhos que devemos fazer.

> Outra coisa bastante difícil é saber que ideologias cada um destes materiais defende... temos que ler e discutir bastante já que muitos 
textos tentam fortalecer a ideia de que a vida concreta, que vivemos no campo, não tem importância para melhorar a cultura geral. Que a cultura do campo é uma cultura menor.

> Sabermos das possibilidades de mudança econômica advindas do uso de Blogs, web sites, redes de relacionamento, e-governo nos permitiu entender que podemos mudar nossa relação com a natureza e com os demais sujeitos da comunidade, produzindo melhor, organizando-nos melhor, criando consciência de nosso papel social no mundo... Porque é a partir do momento em que pensamos nossas necessidades de sobrevivência que entendemos melhor porque existem leis, a política, o Estado: muitas vezes é para controlar quem produz o quê para quem.

De fato, temos em construção uma inteligência coletiva amparada nos meios de comunicação digital. As pessoas que trabalham falam do que fazem, os artistas falam de sua arte, os políticos falam de seus projetos, etc. Cada segmento vai, pouco a pouco, ocupando os espaços do ciberespaço. Muitas instituições e pessoas têm perfil no Facebook, Sites, Blogs, e postam seus pensamentos e suas atividades.

> A impressão é de que não saber lidar com isso, no sentido de não conhecer para visualizar e postar, acaba marginalizando, ainda mais, o homem do campo. Na educação, então, nem se fala... como a gente irá fazer os trabalhos da LEdoC-UnB sem Internet, sabendo que a Biblioteca Central (da UnB com livros impressos) fica a muitos quilômetros daqui?

> Mas é triste saber que esses recursos são mais acessíveis a quem já tem o poder, que estuda ou estudou em boas escolas de Ensino Médio, que pôde se preparar melhorar para entrar na UnB, por exemplo.

> Somos levados a pensar no quanto nos é difícil comprar e possuir um notebook, por exemplo, para podermos acessar por nossa conta, esses recursos. E na comunidade ainda tem a falta da Internet. Sem computador e Internet, nossas necessidades de aprender são muito prejudicadas.

Agora, para ter um notebook, que é muito caro, temos que 
trabalhar muitos dias, sabendo que o fabricante, dono da tecnologia de fazer notebooks, levou apenas alguns minutos para fazê-lo.

> Quando comparamos nossa capacidade de produzir com a capacidade de produzir de quem possui as tecnologias mais novas vemos que há uma disparidade grande entre quem possui e quem não possui essas tecnologias de produção. Desse jeito, vamos ficando cada vez mais afastados da informação e do conhecimento e cada vez fica mais difícil mudar a realidade de nossas vidas.

\section{Aulas 11 e 12}

\section{Conteúdo}

$>$ A relação entre conhecimento e poder;

> Atuação nas mídias digitais e inclusão social;

> Sociedade em Rede;

> Rede social: a importância do perfil;

$>$ Conteúdos proprietários e conteúdos abertos.

\section{Objetivos}

- Levantar questões sobre a nova dinâmica social onde o valor é a informação e o domínio dos meios de comunicação é fundamental para a inserção dos atores sociais nos fluxos da sociedade contemporânea; criar perfil em rede social (Facebook);

> Discutir a importância dos conteúdos abertos em contraposição aos conteúdos proprietários para a Educação do Campo.

\section{Conceitos permeadores}

$>$ Força de trabalho;

Mercadoria

\section{Síntese dos aprendizados}


Um dos principais sintomas de que saber usar computador e Internet é um dentre os muitos elementos de poder na sociedade contemporânea aparece entre nós: maior parte dos educandos não sabe lidar com esses equipamentos e o Estado não parece estar muito interessado em nos dar essa oportunidade, porque para o Estado é interessante nos manter ignorantes sobre essas novas formas de agir e participar da sociedade. Ou seja, o Estado não facilita o nosso acesso e a nossa apropriação destes recursos tecnológicos porque isso pode nos fazer ficar mais críticos e atentos aos movimentos da hegemonia.

$>$ Ter conhecimento é ter poder, pois saber ler o mundo nos torna mais atentos às exclusões e às dominações. Computador e Internet podem ser muito úteis neste sentido, permitindo-nos acesso à informação e servindo como instrumentos de nossa expressão. Além disso, o ciberespaço pode constituir-se espaço de expressão de nossas precárias condições de vida e de produção, sendo útil para que nossa voz possa se propagar por mais um canal.

> Não é por acaso que poucos são os sujeitos do campo que conseguem entrar na UnB como educandos: o sistema vai colocando uma série de dificuldades para o pobre acessar educação de qualidade com a intenção de deixar de fora da educação de qualidade quem já vem sendo excluído da educação há muito tempo na Educação Básica.

> Desse modo, o estudante do campo que já estudava em escolas precárias no campo (sem professor com boa formação, sem salas de aula e transporte dignos) passando todo tipo de privação educativa, chega ao tempo do vestibular (depois do ensino médio) com pouquíssimas chances de concorrer com os estudantes das escolas da cidade. Sem contar que boa parte dos educandos da cidade estuda em escolas particulares com toda uma boa estrutura de ensinamentos específicos para a entrada na Universidade.

D Isso deixa claro que ter conhecimento é ter poder. E que o capitalismo sabe disso, e, para manter pessoas com pretensões salariais pequenas, acaba organizando o mundo para que apenas alguns 
possam ter educação de qualidade e os demais continuem vendendo sua força de trabalho barata.

> Assim se reforça cada vez mais a ideia de que o trabalhador é uma coisa, uma mercadoria a mais organizável pelo seu grau de estudo, por exemplo. E quanto mais sem educação o trabalhador for, mais incapaz de ser dono de sua capacidade de trabalho ele será. $E$ venderá sua mão de obra ao preço que o patrão quiser pagar.

Uma das formas de se rebelar contra isso talvez seja usarmos as redes sociais como canais para mostrar ao Brasil que apesar da propaganda de um país rico, ainda há muita pobreza por aqui e, muitas vezes, pobreza de conhecimento. As redes sociais, as novas mídias podem colaborar com essa necessidade de expressão. Todavia ainda temos que aprender como usar e ter os equipamentos necessários para isso. Ter visibilidade social é importante para ter a voz ouvida. $\mathrm{O}$ uso de redes sociais digitais pode constituir-se numa importante ferramenta para isso.

> Os conteúdos abertos possibilitam aos movimentos sociais e aos sujeitos do campo a utilização e a produção desses materiais sem que esses atores sejam excluídos do acesso e produção de conhecimento, enquanto os conteúdos proprietários apenas geram mais valia para os grandes empresários das Tecnologias Digitais.

\section{Aulas 13 e 14}

\section{Conteúdo}

> Importância de cada meio de comunicação no campo;

> Meios de comunicação digital (computador, celular, Internet, etc.) e meios de comunicação tradicionais (Carta, Telefone fixo, Televisão, Rádio, etc.);

> Funções dos buscadores Google, Bing, Cadê;

> Objetos de Aprendizagem e Recursos Educacionais Abertos. 


\section{Objetivos}

- Analisar os meios e as formas de comunicação e suas implicações no cotidiano das comunidades rurais a partir das informações coletadas no questionário proposto no semestre anterior.

> Elaborar estratégias de pesquisa usando buscadores na Internet.

> Produzir Objetos de Aprendizagem e/ou Recursos Educacionais Abertos para utilizar no Tempo Comunidade e no Seminário de Tempo Comunidade.

\section{Conceitos permeadores}

Mais valia absoluta;

Mais valia relativa

\section{Síntese dos aprendizados}

$\mathrm{Na}$ Educação Básica nós éramos levados a pensar os meios de comunicação de modo isolado da sociedade, do homem e do trabalho. Hoje aprendemos que discutir os meios de comunicação levanos a refletir sobre a nossa própria evolução como seres sociais, sobre nossa própria condição de sujeitos com necessidades de expressão e com linguagens diversas, sejam elas audiovisuais, de escrita, do gestual.

> Olhando para essa nova leitura dos meios de comunicação entendemos que quando formos atuar como educadores da Educação Básica do Campo teremos que fazer da mesma forma: ampliar o discurso para além dos artefatos tecnológicos da comunicação. Tratar comunicação como um sistema que tem ligações com os diversos segmentos da vida humana. É pensar a comunicação articulada com a educação, com o trabalho, com a expressão da dominação ou da contra dominação.

D Essa forma de pensar, por exemplo, a comunicação de modo isolado da totalidade da realidade social, se relaciona, analogamente, com a 
separação entre o homem e a totalidade do seu trabalho. Assim como no trabalho somos levados a refletir sobre ele de modo fragmentado, na comunicação isso acontece. Parece que compreender os papéis mais profundos da comunicação pode empoderar os sujeitos a utilizar seus meios como forma de se rebelar... assim como pensar o trabalho, também o é.

- Refletir sobre o papel social dos meios de comunicação é muito mais que fazer uma lista dos recursos de comunicação existentes em uma sociedade ou comunidade. É entender que relações de poder moram nas formas e intencionalidades da invenção e desenvolvimento de cada um destes recursos.

> Se não discutimos isso de modo crítico acabamos por não entender que tal análise é muito mais do que possa parecer em um primeiro olhar: há intenções de manter e fortalecer a dominação de uma classe pela outra; de sustentar o modo de produção onde o homem está cada vez mais distante de entender seu processo de trabalho e produção; afastar o trabalhador do aprendizado sobre como dominar técnicas de desenvolvimento de tecnologias de informação, pois isso é fonte de poder; aumentar o lucro das empresas que criam e exploram os meios de comunicação em função de que a maior parte dos sujeitos não entende seus processos de produção e suas intencionalidades subjacentes de fortalecimento da dominação.

Quanto mais modernos os meios de comunicação (celular, computador, Internet, etc), mais eles contribuem para garantir o aumento de lucro dos donos dos meios de produção. Afinal, grande parte das funções dos meios de comunicação digitais é maximizar a produção, aumentando lucros, reduzindo custos, dando ênfase na ideia da máquina como fonte de trabalho mais eficiente que o homem e usando isso como justificativa para pagar cada vez menos pela força de trabalho dos sujeitos.

> Antes, a produção era mais incrementada com o aumento das horas de trabalho do trabalhador com um salário cada vez menor possível, 
com as novas tecnologias o homem reduz o tempo de produção dos bens e aumenta a lucratividade no mesmo tempo. Com isso, o patrão conseguiu novas formas de sugar mais e mais do potencial de trabalho do homem e da máquina que é produzida também pelo homem. É o uso do trabalho do homem no sentido de gerar mais desvalorização do trabalho do próprio homem.

Um destaque para o fato de que cada vez mais são criadas novas tecnologias de comunicação de massas e isso reforça a necessidade de olhares críticos sobre esse movimento que, provavelmente, potencializa a capacidade de inculcar ideologias e reafirmar as formas de dominação suportadas por novas formas de comunicar e produzir.

Aprender a produzir, remixar e compartilhar Recursos Educacionais Abertos abre um leque de opções para melhorar e qualificar o trabalho pedagógico na Escola do Campo, pois além de valorizar os conhecimentos tradicionais, possibilita ao docente e aos educandos a autoria própria.

\section{Aula 15 e 16}

\section{Conteúdo}

> Internet e educação: possibilidades;

> Ambientes Virtuais de Aprendizagem;

> Objetos de Aprendizagem e Recursos Educacionais Abertos;

> Repositórios de REA.

\section{Objetivos}

> Debater sobre a Internet como meio para a formação continuada.

$>$ Conhecer funções e usos de Ambiente Virtual de Aprendizagem e Objetos de aprendizagem.

Acessar Ambiente Virtual de Aprendizagem e repositórios diversos e 
experimentar Objetos de Aprendizagem e/ou Recursos Educacionais Abertos.

> Produzir, remixar e compartilhar Recursos Educacionais Abertos contextualizados e elaborados pelos sujeitos das relações educativas das Escolas do Campo.

\section{Conceitos permeadores}

O fetichismo da mercadoria

\section{Síntese dos aprendizados}

A Internet tem várias faces: umas positivas outras negativas. No seio desta discussão também reside a luta dos contrários. Dentre os aspectos positivos no trato sobre Internet e educação há a questão da velocidade e da abrangência. Com a Internet a busca de textos, vídeos, imagens e outras formas de expressão é bastante rápida e diferente das formas tradicionais de buscas como em uma biblioteca física, por exemplo. Há uma grande quantidade de informações em todas as áreas de conhecimento circulante na Internet. É possível encontrar informações sobre tudo.

A forma como a Internet é estruturada pode acelerar processos de renovação de ideias, conceitos, possibilidades pela comunicação instantânea entre pares com objetivos similares e os produtos disso podem ser divulgados em âmbito global. Na educação, novas formas de produzir conhecimentos são fomentadas a partir da invenção de novas ferramentas de criação individual e coletiva. Há relatos de criação de jornais digitais, Blogs educativos, enquetes eletrônicas, banco de dados de informações, etc. produzidos por educandos em escolas de todos os níveis educacionais. Com um detalhe importante: geralmente os processos são coletivos e interativos e o conteúdo multimídia como imagens, pequenos vídeos, textos, arquivos de áudio, etc.

> A interação entre educandos, informações e o educador mediados em 
ambientes online baseados em Softwares educativos permite a construção do conhecimento de outras formas para além da sala de aula tradicional. Isso pode ocorrer quando se navega pela Internet entrando em contato com os conteúdos, escolhendo o que melhor se adequa ao planejamento da aula e durante isso ainda poder manter contato com seus colegas e educadores num processo de trocas pedagógicas ricas.

A cooperação é outro valor que pode ser desenvolvido em atividades usando Internet e educação diminuindo, às vezes, problemas de comunicação como a timidez. A interação com finalidade educativa possível pela Internet com suas Redes Sociais e fóruns ampliam as formas de interação e diálogo tradicionais. Acrescente-se a isso a presença das informações a um clique.

$>$ O computador é um equipamento de uso individual e por isso leva o nome de Personal Computer e isso gera a possibilidade do desenvolvimento de um comportamento autônomo na execução de uma série de tarefas com o auxílio do próprio computador para a solução de problemas que eventualmente surjam. Isso pode ser feito com o auxílio de arquivos de ajuda, buscadores, tutoriais, vídeoaulas, esquemas de faça-você-mesmo.

Outra característica é a possibilidade de fazer inúmeras tarefas concomitantes como, por exemplo: assistir a um vídeo enquanto se lê um arquivo de texto; ouvir música enquanto se edita uma imagem; produzir arquivo de música enquanto se pesquisa um texto, etc. A maior parte dos computadores permite esse tipo de operações concomitantes.

Todavia, o uso de Internet de um modo geral e também na educação apresenta problemas. Um deles é de não termos confiabilidade nas informações de usuários diversos e nem garantias da autoria dos dados disponíveis.

Outro fator importante diz respeito à privacidade na Rede: há que se ter muito cuidado com as informações pessoais já que há pessoas 
especializadas na utilização fraudulenta das informações inseridas na Internet. Além disso, existe a possibilidade de conteúdos perigosos serem divulgados com a atribuição criminosa da autoria a uma pessoa que de fato não produziu este material. Nas Redes Sociais, principalmente, aqueles que criam um perfil passam a estar expostos em escala planetária e é necessário muito cuidado com o que se posta, o que se replica, o que se diz.

Um fator importante a ser destacado é a questão da dependência que o uso da Internet causa. Dependência dos usuários quanto ao conteúdo, pois passam a procurar informações somente neste meio e a dependência patológica que alguns acabam desenvolvendo e que pode ser comparada a dependência química. Existem até clínicas especializadas na dependência tecnológica.

A relação com computador e Internet pode causar essa dependência e um dos traços desse problema é o isolamento. $O$ excesso de imersão dos sujeitos no ciberespaço pode levar à substituição das relações interpessoais físicas apenas pelas relações na Internet. Isso pode empobrecer relações importantes como com amigos, familiares, colegas de escola, etc.

Outro aspecto detectado na discussão sobre a Internet e seu papel na educação diz respeito à grande quantidade de informações disponíveis e que vão tendo sua quantidade exponencialmente aumentada. Isso pode gerar estresse cognitivo, pois ainda não somos capazes de processar toda essa quantidade de informação. A Internet é uma tecnologia para ser utilizada a serviço do homem e não deve ser escravizadora.

A Internet é um ambiente de acesso à informação, mas também é um espaço de interações diversas que buscam refletir e reproduzir as relações da vida não virtual. A Internet tem alto poder de propaganda, de venda, de expressão ideológica.

Desse modo, a própria Internet tem que ser vista como um equipamento que fortalece processos de adoração da mercadoria. 
A própria Internet é uma mercadoria. Há, inclusive, jogos em que os jogadores precisam comprar dinheiro virtual com dinheiro real.

> A produção e o compartilhamento de Recursos Educacionais Abertos pelos sujeitos e coletivos do campo podem promover o fortalecimento do movimento da Educação do Campo e também o movimento por um projeto societário voltado para a classe trabalhadora, gerando materiais contextualizados e, ao mesmo tempo, politizados.

> Essa produção e compartilhamento de REA poderá inaugurar novos materiais didáticos e pedagógicos, tirando o foco do livro didático e dos materiais de sistemas de ensino, que em sua maioria só visam o lucro, deixando a desejar em relação à sua qualidade. 


\begin{tabular}{l} 
APÊNDICE C - Roteiro de Entrevista \\
1. Nome \\
Qual é o seu nome completo? \\
2. Local de atuação \\
Em qual comunidade você mora/atua? \\
3. Contato \\
Qual é o seu e-mail ou telefone de contato? \\
4. Atuação na docência (Uma opção) \\
Quando começou a cursar a LEdoC você já trabalhava como docente no campo? \\
\hline \begin{tabular}{|l|l|}
\hline A. ( ) & Não. \\
\hline B. ( ) & Sim. \\
\hline C. ( ) & Atuava em escola do campo, mas não na docência diretamente. \\
\hline D. ( ) & Outra resposta. Qual? \\
\hline
\end{tabular} \\
\hline
\end{tabular}

\section{Atuação na docência depois de licenciado (Uma opção)}

Após a cursar a LEdoC você trabalha ou trabalhou como docente no campo?

\begin{tabular}{|l|l|}
\hline A. ( $)$ & Não. \\
\hline B. ( $)$ & Sim. \\
\hline C. ( ) & Atuo/atuei em escola do campo, mas não na docência diretamente. \\
\hline D. ( ) & Outra resposta. Qual? \\
& \\
\hline
\end{tabular}

\section{Uso do computador para planejamento (Uma opção)}

Você utiliza o computador para o planejamento de suas aulas (seja para fazer o planejamento ou para pesquisar materiais)?

\begin{tabular}{|c|c|}
\hline A. ( & Nunca. \\
\hline B. ( & Raramente. \\
\hline C. ( & Às vezes. \\
\hline D. ( & Quase sempre. \\
\hline E. ( & Sempre. \\
\hline
\end{tabular}

7. Uso de computador e Internet para preparação de materiais (Uma opção) 
Você utiliza o computador e a Internet para preparar os materiais que vai utilizar em suas aulas?

\begin{tabular}{|l|l|}
\hline A. ( ) & Nunca. \\
\hline B. ( ) & Raramente. \\
\hline C. ( ) & Às vezes. \\
\hline D. ( ) & Quase sempre. \\
\hline E. ( ) & Sempre. \\
\hline
\end{tabular}

\section{Local da utilização do computador/Internet (Mais de uma opção)}

Quando utiliza computador e Internet nas aulas, você o faz em qual local?
A. ( )
B. ( )
C. $($ )
D. ( )
E. ( )
F. ( )
Laboratório de Informática da escola
Casa Digital
Outro tipo de Telecentro
Sala de aula
Na secretaria da escola
Em outro local. Qual?

\section{Utilização do computador em aula (Mais de uma opção)}

Quando utiliza o computador em suas aulas, de que modo faz essa utilização?

\begin{tabular}{|l|l|}
\hline A. ( ) & Uso apresentações (tipo PowerPoint) encontradas na Web \\
\hline B. ( ) & Trago filmes para exibir e explorar \\
\hline C. ( ) & Utilizo o editor de texto (tipo Word) \\
\hline D. ( ) & Utilizo Objetos de Aprendizagem diversos encontrados na rede \\
\hline E. ( $)$ & $\begin{array}{l}\text { Preparo imagens, textos, apresentações e outros materiais de } \\
\text { minha própria autoria }\end{array}$ \\
\hline F. ( ) & Uso o editor de imagens (tipo Paint) \\
\hline G. ( ) & Reproduzo músicas e áudios diversos \\
\hline H. ( ) & Faço utilização do editor de tabelas e planilhas (tipo Excel) \\
\hline I. ( ) & Utilizo para fazer pesquisas na Web junto com os educandos \\
\hline J. ( ) & Uso Recursos Educacionais Abertos encontrados na Web \\
\hline K. ( ) & Utilizamos blogs em nossas aulas \\
\hline L. ( $)$ & $\begin{array}{l}\text { Faço uso de um Ambiente Virtual de Aprendizagem com meus } \\
\text { estudantes }\end{array}$ \\
\hline M. ( ) & Disponibilizo jogos \\
\hline N. ( $)$ & Apresento simulações \\
\hline O. ( ) & Utilizo outros materiais não elencados nas opções anteriores. \\
\hline
\end{tabular}

\section{Contato com REA (Uma opção)}

Você já ouviu falar em Recursos Educacionais Abertos, também chamados de REA?
A. ( ) Não.
B. ( ) Sim. 


\section{A partir do uso de Tecnologias Digitais 1}

O que mudou em sua prática pedagógica depois que começou a utilizar o computador e a Internet?

\section{A partir do uso de Tecnologias Digitais 2}

O que mudou na sua relação com os estudantes a partir do uso das Tecnologias Digitais nas suas aulas?

\section{A partir do uso das Tecnologias Digitais 3}

O que mudou na forma como os educandos se relacionam com o conhecimento a partir do uso do computador nas aulas?

\section{A partir do uso das Tecnologias Digitais 4}

O que você acha que o uso de Tecnologias Digitais Ihe proporcionou, facilidades ou dificuldades no trabalho pedagógico? Por quê?

\section{Recursos Educacionais Abertos 1}

O que são Recursos Educacionais Abertos, também chamados de REA, pra você? (Pode ser o que você já ouviu falar ou o que você imagina ser, diga com suas palavras).

\section{Recursos Educacionais Abertos 2 (Marcar apenas uma opção)}

De acordo com a definição estabelecida pela Unesco/Commonwealth of Learning, em 2011, Recursos Educacionais Abertos são materiais de ensino, aprendizado, e pesquisa em qualquer suporte ou mídia, que estão sob domínio público, ou estão licenciados de maneira aberta, permitindo que sejam utilizados ou adaptados por terceiros. O uso de formatos técnicos abertos facilita o acesso e o reuso potencial dos recursos publicados digitalmente. Recursos educacionais abertos podem incluir cursos completos, partes de cursos, módulos, livros didáticos, artigos de pesquisa, vídeos, testes, software, e qualquer outra ferramenta, material ou técnica que possa apoiar o acesso ao conhecimento (STAROBINAS, 2012, pp.122-123). Sendo assim, reflita e responda: você já utilizou ou utiliza REA em suas aulas?
A.
Nunca utilizei nenhum tipo de REA

B. ( ) Já utilizei uma ou duas vezes 


\begin{tabular}{|l|l|}
\hline C. ( ) & Quase sempre utilizo \\
\hline D. ( $)$ & Sempre utilizo \\
\hline E. ( ) & Continuo sem compreender o que são REA \\
\hline F. ( ) & Outra resposta. Qual? \\
\hline
\end{tabular}

\section{Recursos Educacionais Abertos 4 (Marcar apenas uma opção)}

Sabendo que Recurso Educacional Aberto é qualquer tipo de recurso digital aberto que pode ser disponibilizado em rede para adaptação e/ou utilização por qualquer pessoa, você também pode produzir e compartilhar esses recursos. Pensando assim, seria possível adaptar e produzir materiais específicos para as comunidades do campo, certo? Você já adaptou ou produziu algum desses materiais para utilização em suas aulas?

\begin{tabular}{|l|l|}
\hline A. ( ) & Não, nunca adaptei e nem produzi REA para utilizar nas aulas. \\
\hline B. ( $)$ & Sim, várias vezes. \\
\hline C. ( $)$ & Sim, apesar de não saber que era um REA. \\
\hline D. ( $)$ & Sim, algumas vezes. \\
\hline E. ( ) & Sim, sempre adapto ou produzo REA. \\
\hline F. ( ) & Sim, já adaptei, mas nunca produzi. \\
\hline G. ( ) & Sim, já produzi, mas nunca adaptei. \\
\hline H. ( ) & Outra resposta. Qual? \\
\hline
\end{tabular}

\section{Recursos Educacionais Abertos 5 (Marcar quantas opções quiser)}

Se é possível adaptar e produzir materiais específicos para as comunidades do campo, a partir da realidade de cada comunidade, você acha que isso proporciona aos educadores do campo:

\begin{tabular}{|c|c|}
\hline A. ( & $\begin{array}{l}\text { Possibilidade de melhorar o trabalho pedagógico por poder } \\
\text { contextualizar o trabalho realizado. }\end{array}$ \\
\hline B. $(\quad)$ & $\begin{array}{l}\text { Possibilidade de qualificar o trabalho pedagógico por poder utilizar } \\
\text { REA produzidos pelos próprios educandos, com características de } \\
\text { sua cultura. }\end{array}$ \\
\hline C. ( & $\begin{array}{l}\text { Possibilidade de transformar as relações educativas por quebrar a } \\
\text { hierarquização existente entre professor e alunos, pois todos } \\
\text { passam a poder ser autores dos materiais didáticos utilizados. }\end{array}$ \\
\hline D. ( & $\begin{array}{l}\text { Dificuldades diversas porque a maioria dos professores não sabe } \\
\text { utilizar o computador. }\end{array}$ \\
\hline E. ( & Mais trabalho porque aumenta mais uma atribuição ao professor. \\
\hline F. ( & $\begin{array}{l}\text { Possibilidade de autoria própria de materiais produzidos de acordo } \\
\text { com a cultura local, suas potencialidades e suas dificuldades. }\end{array}$ \\
\hline G. ( & $\begin{array}{l}\text { Nenhuma das opções anteriores atende ao que penso. } \\
\text { Responderei com minhas palavras a seguir. Justifique. }\end{array}$ \\
\hline
\end{tabular}

\section{Recursos Educacionais Abertos 7}

No seu entendimento, você acha que os Recursos Educacionais Abertos podem 
ajudar a ressignificar a prática pedagógica de educadores do campo? De que modo isso poderia acontecer?

21. Outras palavras para complementar

Você gostaria de complementar com algo sobre o assunto tratado? O que? 


\section{APÊNDICE D - Respostas à entrevista}

Os entrevistados serão tratados, nesta pesquisa, com nomes fictícios de personagens de Guimarães Rosa na obra Grande Sertão Veredas.

Nomes fictícios:

\begin{tabular}{|l|l|}
\hline & Nomes fictícios: \\
\hline 1. & Diadorim \\
\hline 2. & Davidão \\
\hline 3. & Maria Leôncia \\
\hline 4. & Riobaldo \\
\hline 5. & Medeiro Vaz \\
\hline 6. & Otacília \\
\hline 7. & Doutor Fausto \\
\hline 8. & Joca Ramiro \\
\hline 9. & Nhorinhá \\
\hline 10. & Hermógenes \\
\hline 11. & Zé Bebelo \\
\hline
\end{tabular}

3.1 Sobre a atuação da/do entrevistada/o na docência em uma ou mais escolas do campo:

3.1.1 Quando começou a cursar a LEdoC você já trabalhava como docente no campo?

Atuação na docência (Marque apenas uma opção)
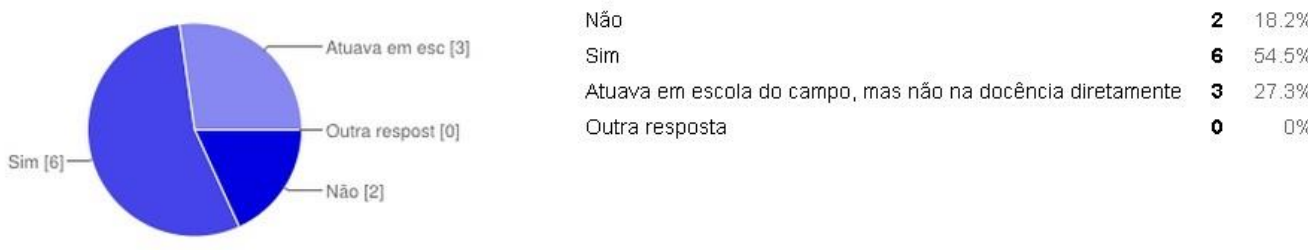

Sim

$654.5 \%$

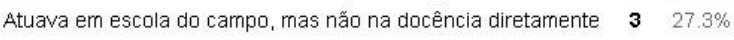

Outra resposta

3.1.2 Após a cursar a LEdoC você trabalha ou trabalhou como docente no campo?

Atuação na docência depois de licenciado (Marque apenas uma opção)

Atuo/atuei em [2]

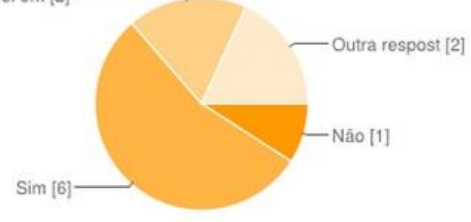

Sim

Atuo/atuei em escola do campo, mas não na docência diretamente. $\quad 2 \quad 18.2 \%$ Outra resposta

3.2 Sobre a utilização do computador em atividades de coordenação pedagógica, ou seja, no planejamento e preparação das aulas e materiais para as mesmas: 
3.2.1 Você utiliza o computador para o planejamento de suas aulas (seja para fazer o planejamento ou para pesquisar materiais)?

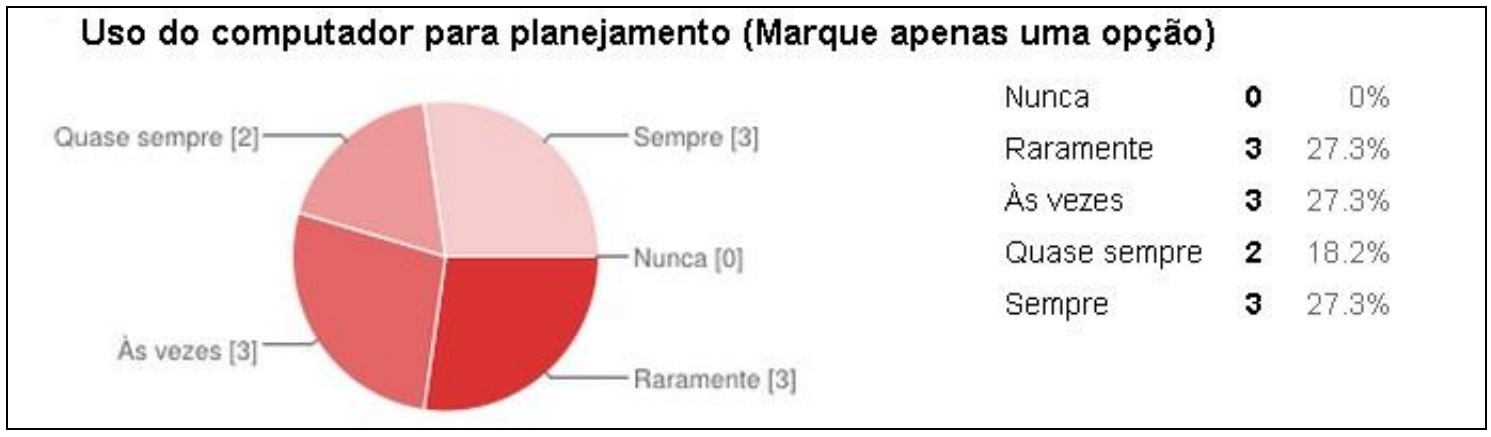

3.2.2 Você utiliza o computador e a Internet para preparar os materiais que vai utilizar em suas aulas?

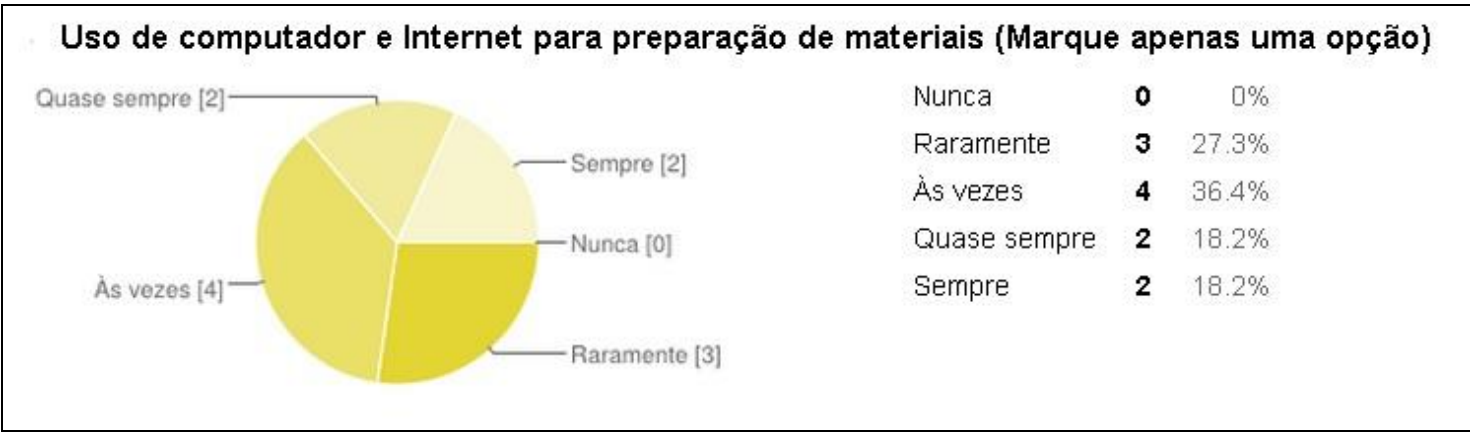

3.3 Sobre a utilização de computador nos momentos de aula, ou seja, com os educandos:

3.3.1 Você utiliza o computador para dar aulas?

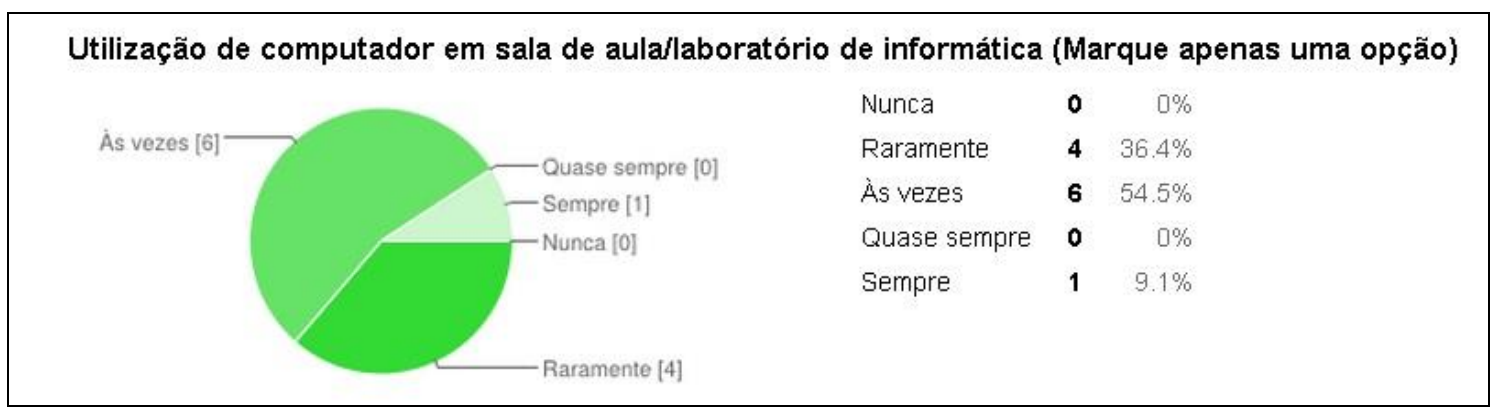

3.3.2 Quando utiliza computador e Internet nas aulas, você o faz em qual local? 


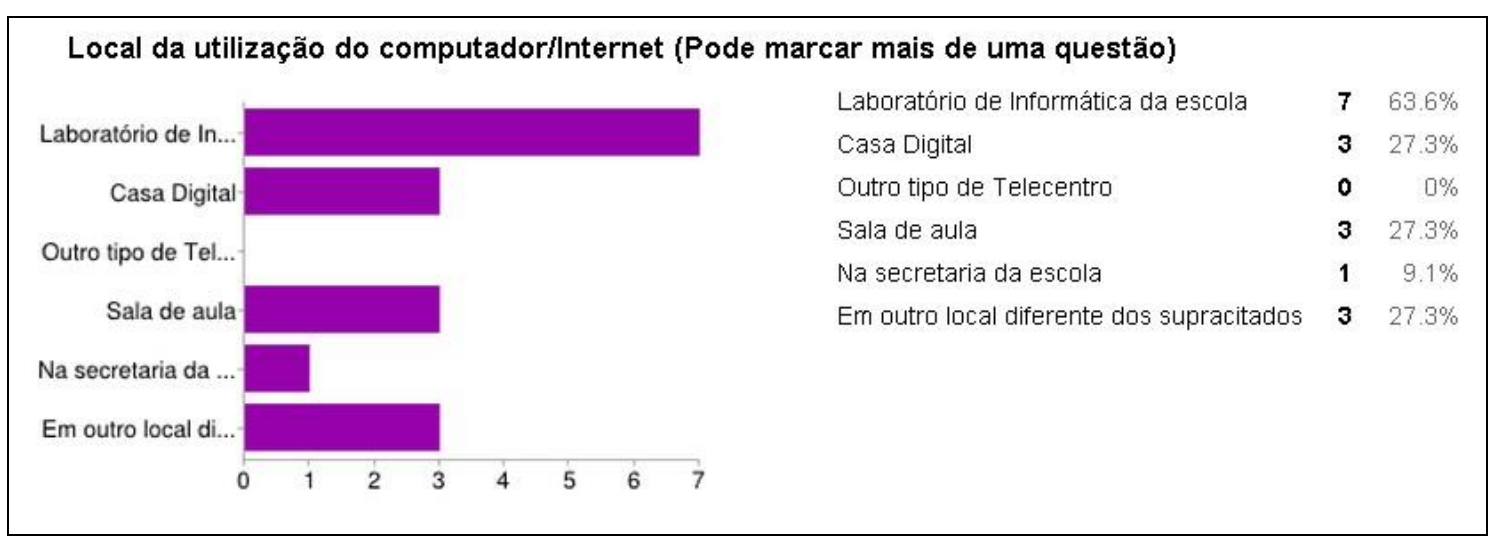

\subsubsection{Quando utiliza o computador em suas aulas, de que} modo faz essa utilização?

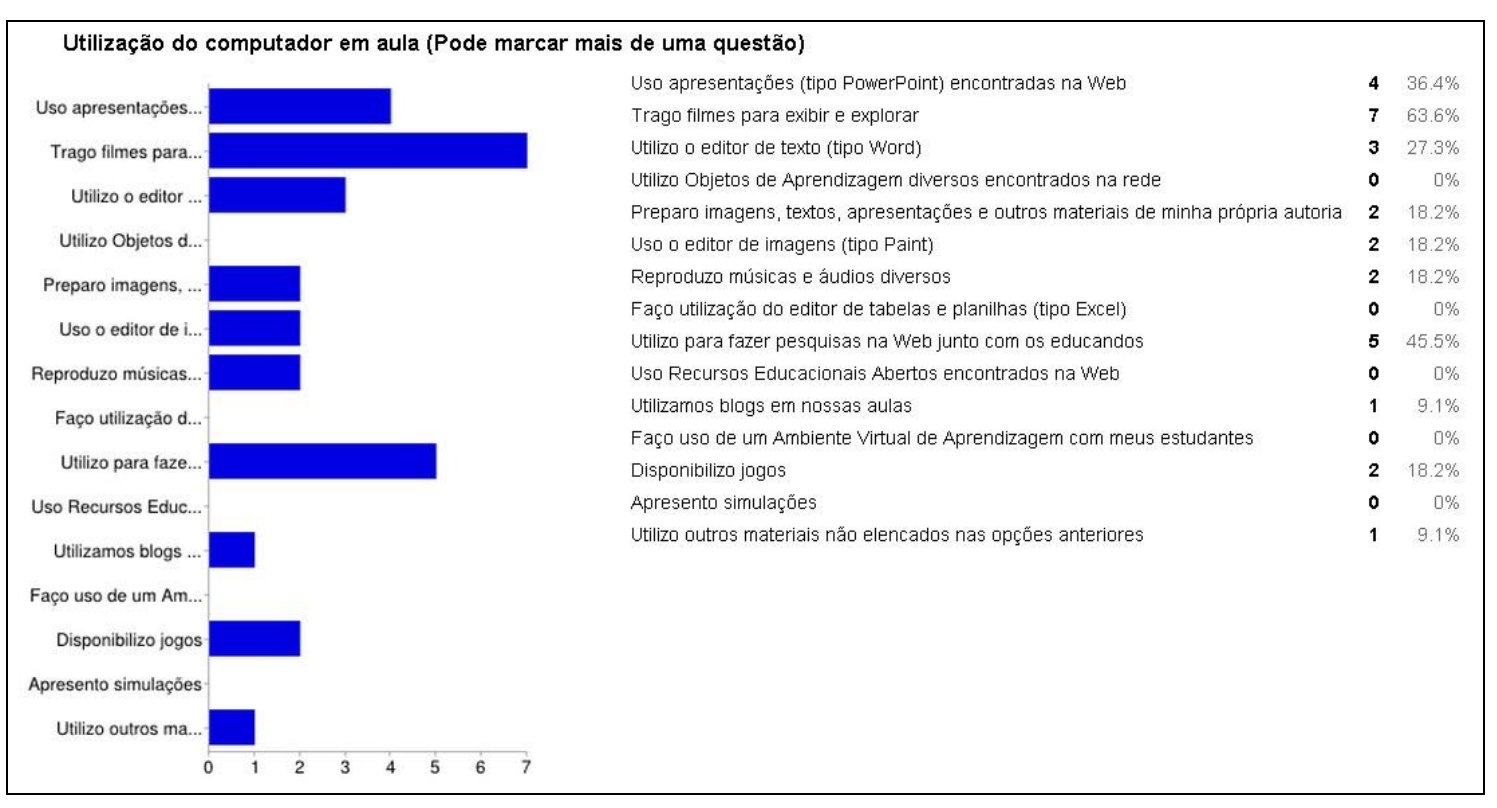

\subsection{A partir do uso de Tecnologias Digitais:}

\subsection{1 $O$ que mudou em sua prática pedagógica depois que}

\section{começou a utilizar o computador e a Internet?}

\begin{tabular}{|l|l|}
\hline Nomes fictícios: & \multicolumn{1}{|c|}{ 12. A partir do uso de Tecnologias Digitais 1 } \\
\hline Diadorim & $\begin{array}{l}\text { Na minha comunidade, os computadores estão servindo } \\
\text { apenas para enfeitar as mesas, porque tem gente que está } \\
\text { com o pezão em cima e não quer nos repassar a senha, além } \\
\text { de faltar equipamentos, por ter desaparecidos após essa } \\
\text { pessoa ter recebido os computadores e ficado aqui na cidade } \\
\text { por um período de mais de dois } 2 \text { anos. Os computadores só } \\
\text { chegaram na comunidade em julho de 2014 e estão lá sem } \\
\text { poder serem usados por falta de senhas. Já tentei entrar em } \\
\text { contato com o MDA, mas sem sucesso por falta de contato do } \\
\text { departamento que cuida dessa área. }\end{array}$ \\
\hline Davidão & $\begin{array}{l}\text { Bom como moro em Assentamento e não temos acesso a } \\
\text { internet, são poucas as vezes q posso utilizar essas } \\
\text { tecnologias, mas as vezes q utilizei ajudaram muito no } \\
\text { desenvolvimento das matérias. }\end{array}$ \\
\hline
\end{tabular}




\begin{tabular}{|l|l|} 
Maria Leôncia & $\begin{array}{l}\text { Bom como moro em Assentamento e não temos acesso a } \\
\text { internet, são poucas as vezes q posso utilizar essas } \\
\text { tecnologias, mas as vezes q utilizei ajudaram muito no } \\
\text { desenvolvimento das matérias. }\end{array}$ \\
\hline Riobaldo & $\begin{array}{l}\text { Aula diversificada, aulas atrativas que contribui para o ensino } \\
\text { aprendizagem. }\end{array}$ \\
\hline Medeiro Vaz & $\begin{array}{l}\text { Abre novas possiblidades de materiais didáticos. Além de } \\
\text { proporcionar muitas fontes de pesquisa. }\end{array}$ \\
\hline Otacília & $\begin{array}{l}\text { Mas material didático. Trabalha Com outros autores, e não } \\
\text { ficar refém só dos materiais que são mandando para a escola, }\end{array}$ \\
\hline Doutor Fausto & $\begin{array}{l}\text { Facilita a preparação de materiais e dos planejamentos, pela } \\
\text { diversidade de conteúdos encontrados. }\end{array}$ \\
\hline Joca Ramiro & $\begin{array}{l}\text { Tem sido um auxílio fundamental, pois, tem contribuído muito } \\
\text { mais com o ensino aprendizagem dos educandos e com o } \\
\text { desenvolvimento das atividades em sala de aula. }\end{array}$ \\
\hline Nhorinhá & $\begin{array}{l}\text { Facilitou o planejamento e a pesquisa de materiais para } \\
\text { utilização em aula. Também acho que melhorei minha escrita } \\
\text { e leitura, o que melhora minha prática também. }\end{array}$ \\
\hline Hermógenes & Ampliação dos horizontes de aprendizagens. \\
\hline Zé Bebelo &
\end{tabular}

3.4.2 0 que mudou na sua relação com os estudantes a partir do uso das tecnologias digitais nas suas aulas?

\begin{tabular}{|l|l|}
\hline Nomes fictícios: & $\begin{array}{l}\text { 13. A partir do uso de Tecnologias } \\
\text { Digitais 2 }\end{array}$ \\
\hline Diadorim & $\begin{array}{l}\text { A vivência dos estudantes com o } \\
\text { computador muda bastante, por que } \\
\text { para eles ainda é algo novo. }\end{array}$ \\
\hline Davidão & $\begin{array}{l}\text { Percebi mais interesse dos } \\
\text { educandos/as em aula. }\end{array}$ \\
\hline Maria Leôncia & $\begin{array}{l}\text { Percebi mais interesse dos } \\
\text { educandos/as em aula. }\end{array}$ \\
\hline Riobaldo & $\begin{array}{l}\text { houve um maior interesse dos } \\
\text { estudantes quando as aulas era } \\
\text { expositiva com slides, filmes e músicas. }\end{array}$ \\
\hline Medeiro Vaz & $\begin{array}{l}\text { Estudar novas tecnologias é falar uma } \\
\text { linguagem dos estudantes. Estes } \\
\text { sempre gostam de aulas dessa maneira. }\end{array}$ \\
\hline Otacília & $\begin{array}{l}\text { Mas material para melhorar o } \\
\text { desempenho dos educados em sala de } \\
\text { aula. e aula com mais dinâmico, mas } \\
\text { envolvimento e participação em sala de } \\
\text { aula. }\end{array}$ \\
\hline Doutor Fausto & $\begin{array}{l}\text { Começamos a desconstruir a ideia de } \\
\text { que a aprendizagem se limita a apenas } \\
\text { ao quadro giz e livro didático. }\end{array}$ \\
\hline Joca Ramiro & $\begin{array}{l}\text { A relação de professor e aluno tem se } \\
\text { tornado muito mais equilibrada. Pois os } \\
\text { educandos tem se demonstrado mais } \\
\text { interessados quando se utiliza das } \\
\text { tecnologias no desenvolvimento das } \\
\text { aulas. }\end{array}$ \\
\hline Nhorinhá & $\begin{array}{l}\text { Passamos a ter uma relação mais } \\
\text { humanizada, de igual pra igual. Eu } \\
\text { ensino para eles e eles me ensinam. } \\
\text { Eles sabem mais do uso das tecnologias } \\
\text { que eu, então fazemos uma troca. }\end{array}$ \\
\hline Hermógenes & \\
\hline
\end{tabular}


Zé Bebelo

Confiabilidade com os educandos/as maior interação.

\subsubsection{O que mudou na forma como os educandos se relacionam com o conhecimento a partir do uso do computador nas aulas?}

\begin{tabular}{|c|c|}
\hline Nomes fictícios: & $\begin{array}{l}\text { 14. A partir do uso das Tecnologias } \\
\text { Digitais } 3\end{array}$ \\
\hline Diadorim & $\begin{array}{l}\text { Mudou muito, primeiro porque tem } \\
\text { estudante na minha comunidade que se } \\
\text { quer conhece um computador. Então eu } \\
\text { uso meu notebook para trabalhar aulas } \\
\text { diferenciadas. }\end{array}$ \\
\hline \multicolumn{2}{|l|}{ Davidão } \\
\hline \multicolumn{2}{|l|}{ Maria Leôncia } \\
\hline Riobaldo & $\begin{array}{l}\text { Ao apresentar maior interesse nas aulas } \\
\text { a partir das tecnologias, isso trouxe um } \\
\text { avanço no ensino e aprendizagem. }\end{array}$ \\
\hline Medeiro Vaz & $\begin{array}{l}\text { Demostraram mais interesse e se motiva } \\
\text { cada vez mais. }\end{array}$ \\
\hline Otacília & $\begin{array}{l}\text { Geralmente os educados quase não tem } \\
\text { acesso ao computador em sala de aula. }\end{array}$ \\
\hline Doutor Fausto & $\begin{array}{l}\text { Eles acham as aulas mais dinâmicas } \\
\text { interessantes, o que facilita a } \\
\text { compreensão do conteúdo. Um fator } \\
\text { importante é que o computador e a } \\
\text { internet oferecem uma variedade de } \\
\text { recursos que possibilita ao estudante a } \\
\text { compreensão e a associação dos } \\
\text { conceitos da realidade. }\end{array}$ \\
\hline Joca Ramiro & $\begin{array}{l}\text { Com o auxílio do computador e da } \\
\text { Internet os educandos tem se } \\
\text { relacionado de maneira prazerosa. Pois, } \\
\text { tem buscado interagir com o } \\
\text { conhecimento com muita agilidade e } \\
\text { praticidade. }\end{array}$ \\
\hline \multicolumn{2}{|l|}{ Nhorinhá } \\
\hline Hermógenes & $\begin{array}{l}\text { Eles passaram a gostar mais da aula. } \\
\text { Parece que agora têm mais incentivo } \\
\text { para estudar. Antes ficavam meio } \\
\text { entediados. Também passaram a gostar } \\
\text { de pesquisar o que querem aprender. }\end{array}$ \\
\hline Zé Bebelo & $\begin{array}{l}\text { Aprendizados uniformes, maiores } \\
\text { intervenções nas aulas. }\end{array}$ \\
\hline
\end{tabular}

\subsubsection{0 que você acha que o uso de tecnologias digitais the proporcionou facilidades ou dificuldades no trabalho pedagógico? Por quê?}

\begin{tabular}{|l|l|}
\hline Nomes fictícios: & $\begin{array}{l}\text { 15. A partir do uso das Tecnologias } \\
\text { Digitais 4 }\end{array}$ \\
\hline Diadorim & Em relação aos telecentros BR ou Casas \\
& Digitais, só dificultou, porque os \\
& estudantes pedem para usar os \\
& computadores e não podemos. \\
\hline Davidão & Facilidades, é claro, já que contribui no \\
\hline
\end{tabular}




\begin{tabular}{|c|c|}
\hline & | aprendizado dos educandos/as. \\
\hline Maria Leôncia & $\begin{array}{l}\text { Facilidades, pois contribui no } \\
\text { aprendizado. }\end{array}$ \\
\hline Riobaldo & $\begin{array}{l}\text { Houve um avanço em questão de } \\
\text { apresentação de slide, filmes e músicas, } \\
\text { mas infelizmente a internet não é } \\
\text { utilizado em sala de aula por que a única } \\
\text { que existe na escola é de uso da } \\
\text { secretaria e ainda assim é de péssima } \\
\text { qualidade. }\end{array}$ \\
\hline Medeiro Vaz & $\begin{array}{l}\text { Facilidades. Mas a dificuldade foi devido } \\
\text { no campoo assesso é precario. Os } \\
\text { computadores apresenta muitos } \\
\text { problemas operacionais. A internet é } \\
\text { bastante lenta. }\end{array}$ \\
\hline Otacília & $\begin{array}{l}\text { O material didático no acesso à } \\
\text { informação, } \quad \text { a maior } \\
\text { dificuldade é que nem todos os } \\
\text { educados tem acesso a Internet. É os } \\
\text { laboratórios na escola e uma raridade } \\
\text { funciona. }\end{array}$ \\
\hline Doutor Fausto & $\begin{array}{l}\text { as facilidades vão desde o } \\
\text { planejamento, que inclui a busca por } \\
\text { materiais e metodologias de trabalho, e } \\
\text { a pratica educativa, uma vez que os } \\
\text { alunos se interessam cada vez mais por } \\
\text { aulas que tem os processos } \\
\text { metodológicos diferenciados. }\end{array}$ \\
\hline Joca Ramiro & $\begin{array}{l}\text { O uso de tecnologias tem me } \\
\text { proporcionado facilidade no trabalho } \\
\text { pedagógico. Pois, estamos passando } \\
\text { por um momento em que já não tem } \\
\text { condições de um educador ficar a mercê } \\
\text { das tecnologias em seu trabalho } \\
\text { pedagógico. }\end{array}$ \\
\hline \multicolumn{2}{|l|}{ Nhorinhá } \\
\hline Hermógenes & $\begin{array}{l}\text { Com certeza facilitou meu trabalho. É } \\
\text { uma pena que nosso acesso à Internet } \\
\text { seja tão limitado, caso contrário, penso } \\
\text { que seria muito mais fácil desenvolver o } \\
\text { trabalho. }\end{array}$ \\
\hline Zé Bebelo & $\begin{array}{l}\text { Facilidades. } \\
\text { Aproveito varios sites para ajudar no } \\
\text { processo de aprendizagem dos } \\
\text { educandos/as. }\end{array}$ \\
\hline
\end{tabular}

3.5 Sobre Recursos Educacionais Abertos - REA:

3.5.1 Você já ouviu falar em Recursos Educacionais Abertos, também chamados de REA? 
Contato com REA (Marque apenas uma opção)

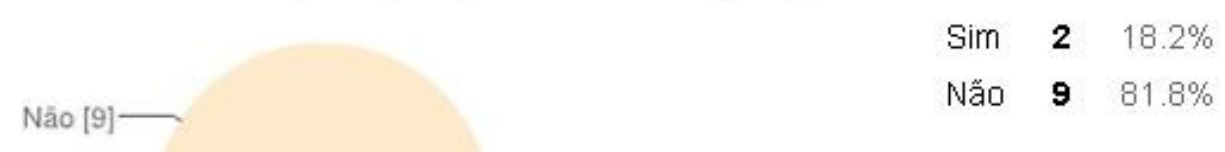

$\sin 218.2 \%$

Nä̀

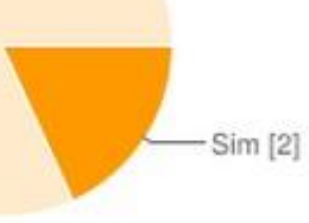

3.5.2 De acordo com a definição estabelecida pela Unesco/Commonwealth of Learning, em 2011, Recursos Educacionais Abertos são materiais de ensino, aprendizado, e pesquisa em qualquer suporte ou mídia, que estão sob domínio público, ou estão licenciados de maneira aberta, permitindo que sejam utilizados ou adaptados por terceiros. $\mathrm{O}$ uso de formatos técnicos abertos facilita o acesso e o reuso potencial dos recursos publicados digitalmente. Recursos educacionais abertos podem incluir cursos completos, partes de cursos, módulos, livros didáticos, artigos de pesquisa, vídeos, testes, software, e qualquer outra ferramenta, material ou técnica que possa apoiar o acesso ao conhecimento (STAROBINAS, 2012, pp.122-123). Sendo assim, reflita e responda: você já utilizou ou utiliza REA em suas aulas?

\begin{tabular}{|l|l|}
\hline Nomes fictícios: & 16. Recursos Educacionais Abertos 1 \\
\hline Diadorim & $\begin{array}{l}\text { Ainda não tive contato com este tipo de } \\
\text { recurso, mas acredito que seja bom. }\end{array}$ \\
\hline Davidão & $\begin{array}{l}\text { Não sei o q é REA, mas acredito q sejam } \\
\text { recursos educacionais q poderemos ter } \\
\text { acesso para facilitar nossa docência. }\end{array}$ \\
\hline Maria Leôncia & $\begin{array}{l}\text { Não sei o q é REA, mas acredito q sejam } \\
\text { recursos educacionais q poderemos ter } \\
\text { acesso para facilitar nossa docência. }\end{array}$ \\
\hline Riobaldo & $\begin{array}{l}\text { Sites de acesso livre para uso } \\
\text { educacional. }\end{array}$ \\
\hline Medeiro Vaz & $\begin{array}{l}\text { Não ouvi falar. Deve ter alguma coisa a } \\
\text { ver com as novas tecnologias } \\
\text { educacionais. }\end{array}$ \\
\hline Otacília & $\begin{array}{l}\text { Então não tiver acesso a esse recurso e } \\
\text { acho que na escola também não. }\end{array}$ \\
\hline Doutor Fausto & $\begin{array}{l}\text { imagino que sejam recursos que podem } \\
\text { ser acessados livremente por } \\
\text { educadores e alunos e que oferecem } \\
\text { uma variedade de possibilidades de } \\
\text { adaptações e usos de acordo com a } \\
\text { realidade dos educandos e educadores. }\end{array}$ \\
\hline Na verdade ainda não tinha ouvido \\
\hline
\end{tabular}




\begin{tabular}{|l|l|} 
& falar... \\
\hline Nhorinhá & Ouvi falar poucas vezes, mas pelo que \\
entendi, são materiais digitais que \\
qualquer pessoa pode fazer e postar e \\
outras pessoas podem usar, modificar e \\
postar novamente. Ou seja, são \\
materiais disponíveis na Internet que \\
podem ser usados e modificados sem \\
ninguém cobrar por esse uso ou \\
modificação.
\end{tabular}

3.5.3 Sabendo que Recurso Educacional Aberto é qualquer tipo de recurso digital aberto que pode ser disponibilizado em rede para adaptação e/ou utilização por qualquer pessoa, você também pode produzir e compartilhar esses recursos. Pensando assim, seria possível adaptar e produzir materiais específicos para as comunidades do campo, certo? Você já adaptou ou produziu algum desses materiais para utilização em suas aulas?

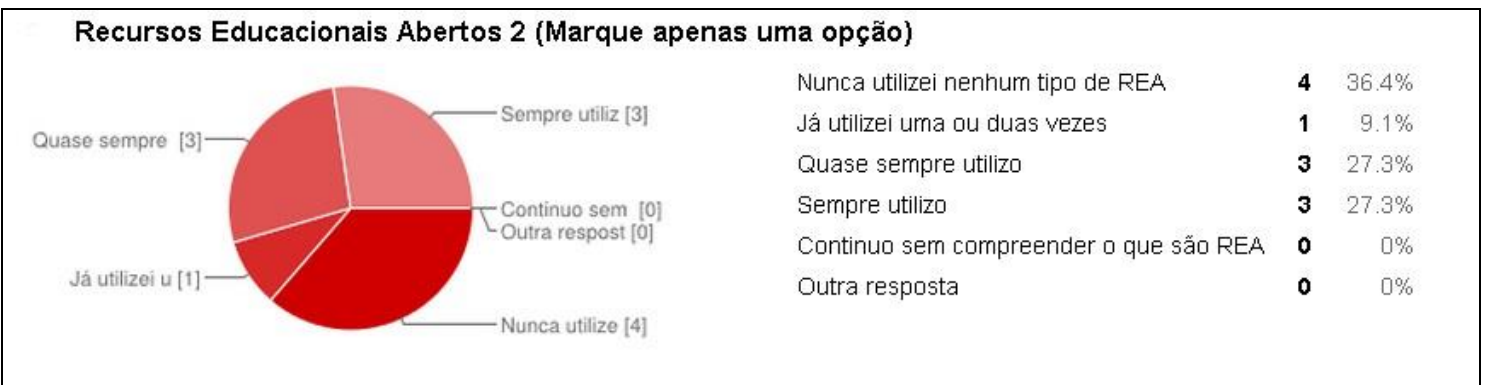

3.5.4 Se é possível adaptar e produzir materiais específicos para as comunidades do campo, a partir da realidade de cada comunidade, você acha que isso proporciona aos educadores do campo:

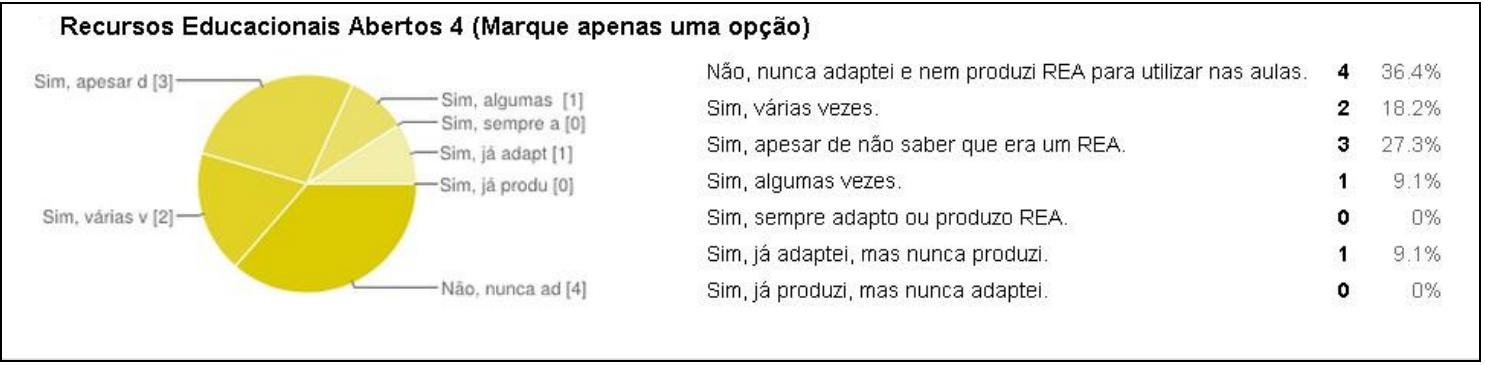




\subsubsection{Se nenhuma das opções apresentadas contemplou o que você pensa ou se você quer complementar as opções escolhidas, o que mais gostaria de dizer a esse respeito?}

\begin{tabular}{|c|c|}
\hline Nomes fictícios: & 20. Recursos Educacionais Abertos 7 \\
\hline Diadorim & Sim. Acho que de uma forma bem democrática. \\
\hline Davidão & $\begin{array}{l}\text { Sim, com certeza. em primeiro lugar as comunidades do campo } \\
\text { todas precisam ter acesso a computadores e a internet, senão } \\
\text { de nada adianta essa discussão. }\end{array}$ \\
\hline Maria Leôncia & $\begin{array}{l}\text { Sim, com certeza. em primeiro lugar as comunidades do campo } \\
\text { todas precisam ter acesso a computadores e a internet, senão } \\
\text { de nada adianta essa discussão. }\end{array}$ \\
\hline Riobaldo & $\begin{array}{l}\text { A utilização de novas mídias para os educadores do campo, só } \\
\text { vem somar com o processo ensino e aprendizagem, mas para } \\
\text { que isso ocorra é preciso está disponível internet de qualidade } \\
\text { para acesso dos professores. }\end{array}$ \\
\hline Medeiro Vaz & $\begin{array}{l}\text { Na medida em as experiencias vai se consolidando a produção } \\
\text { do material propociona o compartilhamento do mesmo. }\end{array}$ \\
\hline Otacília & Na escola ainda não tem essa programa, \\
\hline Doutor Fausto & $\begin{array}{l}\text { através dessa possibilidade de significar o trabalho pedagógico } \\
\text { partindo do ponto de vista da mudança de concepção do uso do } \\
\text { computador e internet no processo de ensino aprendizagem. }\end{array}$ \\
\hline Joca Ramiro & Sim. Com a possibilidade de produzir seus próprios materiais. \\
\hline \multicolumn{2}{|l|}{ Nhorinhá } \\
\hline Hermógenes & $\begin{array}{l}\text { Eu acho que sim. Porque a partir do momento que podemos } \\
\text { produzir materiais a partir da realidade dos educandos, fica mais } \\
\text { fácil contextualizar, os educandos passam a compreender } \\
\text { melhor o que queremos ensinar. Além disso, quem não gosta de } \\
\text { se ver sendo projetado, postado? Os educandos iriam adorar } \\
\text { ajudar a produzir os materiais. }\end{array}$ \\
\hline Zé Bebelo & $\begin{array}{l}\text { Sim. Seminário entre os educadores/as sobre as praticas } \\
\text { pedagogicas. Acompanhamento sistemático sobre o } \\
\text { desenvolvimento da aprendizagem dos educandos/as }\end{array}$ \\
\hline
\end{tabular}

3.5.6 No seu entendimento, você acha que os Recursos

Educacionais Abertos podem ajudar a ressignificar a prática pedagógica de educadores do campo? De que modo isso poderia acontecer? 


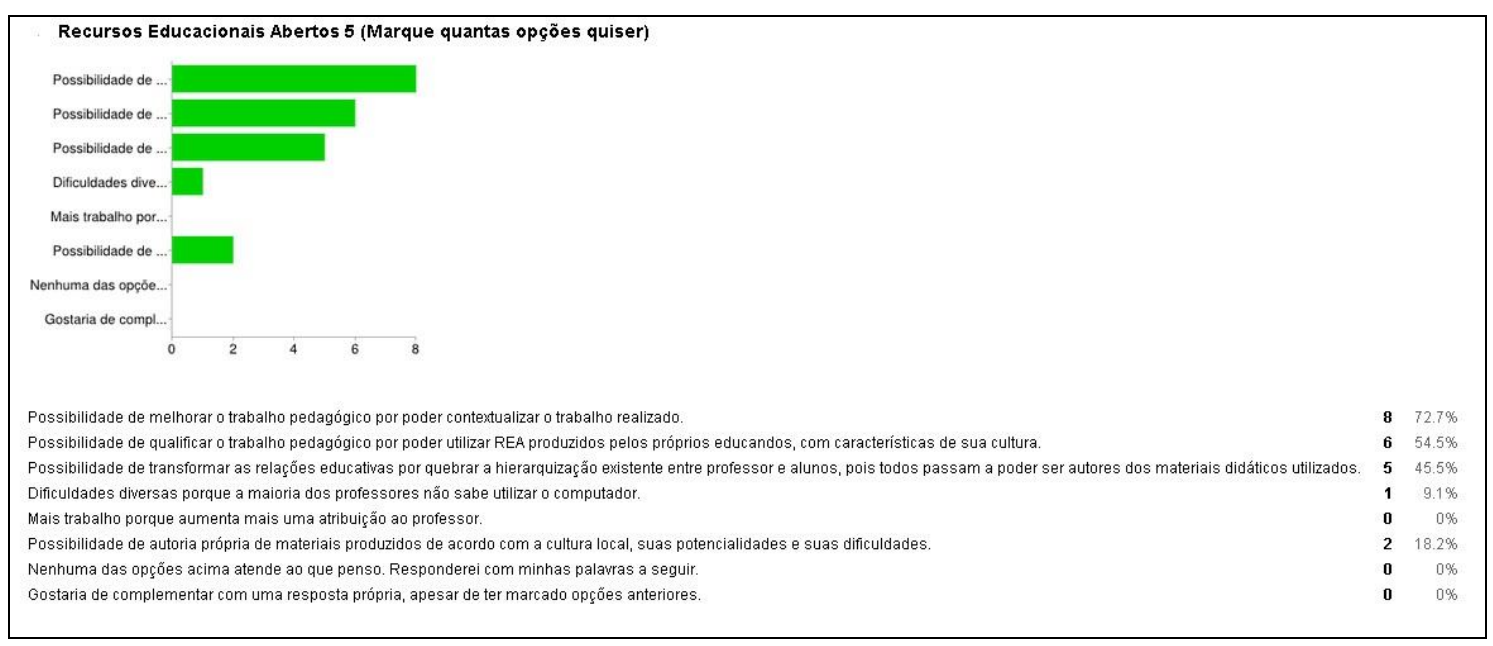

3.6 Complemente a sua fala com algo que você ache que não foi contemplado durante nossa conversa:

\begin{tabular}{|l|l|}
\hline Nomes fictícios: & $\begin{array}{l}\mathbf{2 1 .} \text { Outras palavras para } \\
\text { complementar }\end{array}$ \\
\hline Diadorim & \\
\hline Davidão & \\
\hline Maria Leôncia & \\
\hline Riobaldo & $\begin{array}{l}\text { Então vou pesquisar e levar ao } \\
\text { conhecimento da escola onde trabalho. }\end{array}$ \\
\hline Medeiro Vaz & $\begin{array}{l}\text { Os recursos tecnológicos em especial } \\
\text { o computador e internet podem } \\
\text { impulsionar as praticas educativas e } \\
\text { proporcionar ao educador a } \\
\text { dinamização das aulas melhorando a } \\
\text { qualidade do ensino aprendizagem. }\end{array}$ \\
\hline Otacilia & $\begin{array}{l}\text { Gostaria de poder compreender ainda } \\
\text { mais sobre os REA e conhecer } \\
\text { experiência de produção. }\end{array}$ \\
\hline Doutor Fausto & \\
\hline Joca Ramiro & \\
\hline Nhorinhá & \\
\hline Hermógenes & \\
\hline Zé Bebelo & \\
\hline
\end{tabular}




\section{APÊNDICE E - Termo de Consentimento Livre e Esclarecido}

CONSENTIMENTO DA/O EGRESSA/O DO CURSO DE LICENCIATURA EM EDUCAÇÃO DO CAMPO-UnB

$\mathrm{Eu}$

Egressa/o do Curso de Licenciatura em Educação do Campo-UnB, DECLARO que fui esclarecida/o quanto aos objetivos e procedimentos do estudo "Formação de Educadores do Campo e Tecnologias Digitais: Relações e Desafios na Licenciatura em Educação do Campo da UnB" pela pesquisadora Wanessa de Castro, sob a orientação da Professora Doutora Mônica Castagna Molina, e CONSINTO minha participação neste projeto de pesquisa, a utilização da entrevista dada por mim, para fins de estudo e para publicação em revistas científicas.

Brasília, de de 